\title{
EDUGACÃO GONTEMPORÂNEA
}

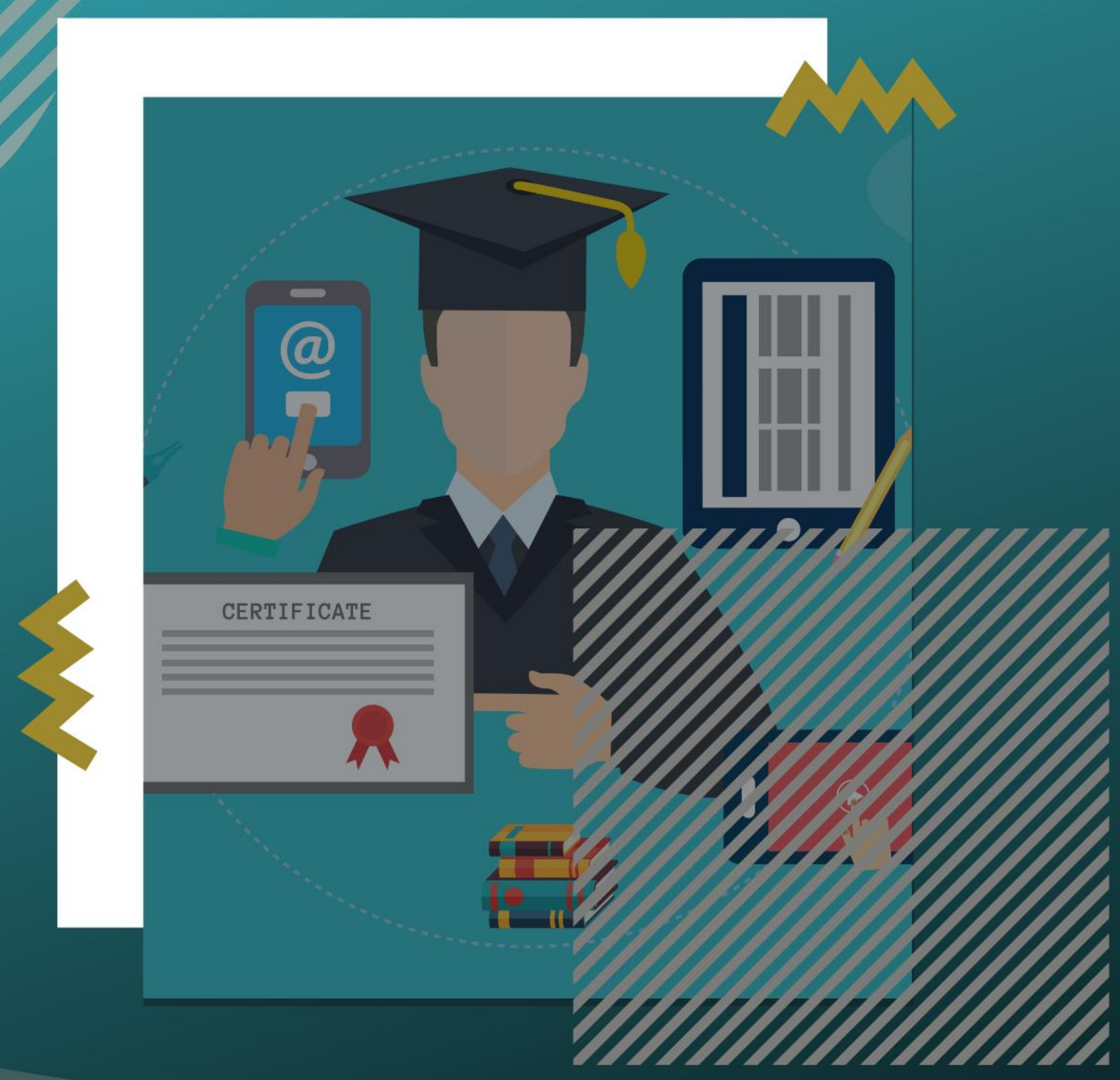

Organizadoras

Maria Célia da Silva Gonçalves

Bruna Guzman de Jesus
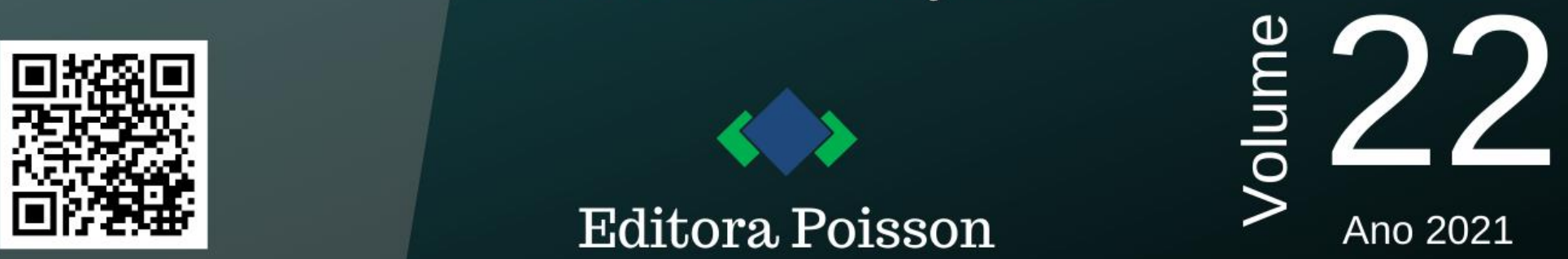

Editora Poisson

Ano 2021 
Maria Célia da Silva Gonçalves

Bruna Guzman de Jesus

(Organizadoras)

\section{Educação Contemporânea - Volume 22}

1a Edição

Belo Horizonte

Poisson

2021 


\section{Editor Chefe: Dr. Darly Fernando Andrade}

\section{Conselho Editorial}

Dr. Antônio Artur de Souza - Universidade Federal de Minas Gerais

Ms. Davilson Eduardo Andrade

Dra. Elizângela de Jesus Oliveira - Universidade Federal do Amazonas

Msc. Fabiane dos Santos

Dr. José Eduardo Ferreira Lopes - Universidade Federal de Uberlândia

Dr. Otaviano Francisco Neves - Pontifícia Universidade Católica de Minas Gerais

Dr. Luiz Cláudio de Lima - Universidade FUMEC

Dr. Nelson Ferreira Filho - Faculdades Kennedy

Ms. Valdiney Alves de Oliveira - Universidade Federal de Uberlândia

Dados Internacionais de Catalogação na Publicação (CIP)

\begin{tabular}{l} 
E24 Educação Contemporânea - Volume 22 / Organização: GONÇALVES, Maria \\
Célia da Silva; JESUS, Bruna Guzman de - Belo Horizonte- MG: \\
Poisson,2021 \\
Formato: PDF \\
ISBN: 978-65-5866-040-8 \\
DOI: 10.36229/978-65-5866-040-8 \\
Modo de acesso: World Wide Web \\
Inclui bibliografia \\
1.História 2.Educação I. GONÇALVES, Maria Célia da Silva II.JESUS, \\
Bruna Guzman. III.Título \\
Sônia Márcia Soares de Moura - CRB 6/1896 \\
\hline
\end{tabular}

O conteúdo dos artigos e seus dados em sua forma, correção e confiabilidade são de responsabilidade exclusiva dos seus respectivos autores

www.poisson.com.br

contato@poisson.com.br 


\section{SUMÁRIO}

Capítulo 1: 0 papel do pedagogo no processo da gestão democrática 08 José Fernando da Silva Alves, Givanildo Melo dos Santos

DOI: 10.36229/978-65-5866-040-8.CAP.01

Capítulo 2: Práticas e desafios da gestão escolar: No contexto da educação pública municipal e interferências político-partidárias 14 Regina Chaves dos Santos

DOI: 10.36229/978-65-5866-040-8.CAP.02

Capítulo 3: Custo da educação pública federal no Brasil: As metodologias utilizadas pelo TCU e pelo MEC. 21

Evandro Cherubini Rolin

DOI: 10.36229/978-65-5866-040-8.CAP.03

Capítulo 4: A racionalidade empresarial na educação de Maceió. 26 Adelson Gomes da Silva, Elione Maria Nogueira Diógenes

DOI: 10.36229/978-65-5866-040-8.CAP.04

Capítulo 5: Educação financeira nas escolas como instrumento de consciência social para adolescentes. 33

Carollini Silva Thomaz Graciani, Leonardo Dias da Silva

DOI: 10.36229/978-65-5866-040-8.CAP.05

Capítulo 6: Valores e ética na educação 39

Adriana Aparecida das Neves de Queiroz, Dayane Lima Viana

DOI: 10.36229/978-65-5866-040-8.CAP.06

Capítulo 7: A identidade nacional brasileira na educação formal 47

Amanda Marques de Carvalho Gondim

DOI: 10.36229/978-65-5866-040-8.CAP.07

Capítulo 8: Políticas Públicas e sua importância na garantia de uma educação de qualidade.

Manuela Gomes Maués, Rosivanda Cunha Moraes

DOI: 10.36229/978-65-5866-040-8.CAP.08 


\section{SUMÁRIO}

Capítulo 9: Percursos das políticas públicas da conservação do patrimônio tangível no Brasil. 60

Karen Velleda Caldas, Flávio Sacco dos Anjos, Javier Bueno Vargas, Micheli Martins Afonso

DOI: 10.36229/978-65-5866-040-8.CAP.09

Capítulo 10: Um olhar transdisciplinar sobre a relação entre currículo e educação integral de acordo com a BNCC no Brasil 76

Gabriela Carradas, Kênia Kemp

DOI: 10.36229/978-65-5866-040-8.CAP.10

Capítulo 11: As Ciências Humanas e a disciplina Geografia no contexto das políticas públicas educacionais atuais no Ensino Fundamental e Médio no Brasil 84

Ana Cláudia Ramos Sacramento

DOI: 10.36229/978-65-5866-040-8.CAP.11

Capítulo 12: Projeto “Departures - de Ponta Grossa para o mundo!": Sintetizando dois anos de realizações 94

Juvancir da Silva, Eugênio Maurício da Silva Neto, Janaína Rodrigues de Almeida, Carolina Scalise Taques Fonseca Schlumberger

DOI: 10.36229/978-65-5866-040-8.CAP.12

Capítulo 13: Levantamento de pesquisas sobre internacionalização no campo de currículo em eventos luso-brasileiros 99

Ana Lisa Nishio, Jussara Cassiano Nascimento

DOI: 10.36229/978-65-5866-040-8.CAP.13

Capítulo 14: Dupla diplomação em Portugal: Percepção dos estudantes de Engenharia Civil da UTFPR dos Câmpus Curitiba e Pato Branco 106

Renata Sá Brito Stramandinoli, Clarice Farian de Lemos, Gustavo Lacerda Dias

DOI: 10.36229/978-65-5866-040-8.CAP.14

Capítulo 15: Possibilidades do uso das Tecnologias da Informação e Comunicação em sala de aula 115

Sunamita de Souza Belido, David de Brito

DOI: 10.36229/978-65-5866-040-8.CAP.15 


\section{SUMÁRIO}

Capítulo 16: A implementação de políticas públicas de tecnologias educacionais nas escolas do Município de Paranaguá: Um olhar crítico

Arlane Queiroz Pereira, Eduardo Alberto da Silva, Larissa Costa Souza, Leticia Izabela Ferreira Guimarães Godoi, Lo Ruama Dyenifer Passos de Souza, Luana Carla Bernardo, Raquel Matciulevitz Moraes de Oliveira, Sthefany dos Santos Pereira

DOI: 10.36229/978-65-5866-040-8.CAP.16

Capítulo 17: As TIC no ensino de Física: Relato de experiência com os conteúdos de ótica 132

Ruth Brito de Figueiredo Melo, Pedro Steinmüller Pimentel, José Edielson da Silva Neves, Gyovanna Kelly Matias do Nascimento, Deivyson Anderson Silva Candido, Olavio Vinícios Barbosa

DOI: 10.36229/978-65-5866-040-8.CAP.17

Capítulo 18: Cursos Superiores de Tecnologia: Inserção e importância no atual cenário educacional brasileiro 138

Sylvia Cristina de Azevedo Vitti

DOI: 10.36229/978-65-5866-040-8.CAP.18

Capítulo 19: Ensino de engenharia na modalidade remota: A adaptação da disciplina de Saneamento Básico e Ambiental I 146

Paula Nobre de Andrade, Maria Bernadette Frota Amora Silva

DOI: 10.36229/978-65-5866-040-8.CAP.19

Capítulo 20: 0 papel do tutor no desenvolvimento dos alunos: Cenários e desafios da Covid-19 no Ensino Superior 155

Alan Rangel Alves, João Paulo Tenório da Silva, Maria Ieda Monteiro, Mário Henrique Monteiro Nascimento, Priscila Débora Ramos, Rodrigo Barbosa Oliveira e Silva, Yuri Ravell Nobre Costa

DOI: 10.36229/978-65-5866-040-8.CAP.20

Capítulo 21: (Re)significação da prática docente na pandemia por Covid-19: Ensino remoto emergencial, novos sentidos, novas perspectivas. 163

Suzyneide Soares Dantas Valcácio

DOI: 10.36229/978-65-5866-040-8.CAP.21 


\section{SUMÁRIO}

Capítulo 22: A equação que Einstein sonhou: Equação de Tudo 169 André Luis Bonaventura, Barbara Alves Nascimento Marques DOI: 10.36229/978-65-5866-040-8.CAP.22

Capítulo 23: Considerações sobre testes de normalidade utilizados pelo Software Gretl 174

Gérson dos Santos Nunes, Viviane Leite Dias de Mattos, Andrea Cristina Konrath DOI: 10.36229/978-65-5866-040-8.CAP.23

Autores: 179 


\section{Capítulo 1}

\section{O papel do pedagogo no processo da gestão democrática}

\section{José Fernando da Silva Alves \\ Givanildo Melo dos Santos}

Resumo: Este artigo tem como objetivo analisar e discutir o trabalho do pedagogo no processo da gestão democrática. Para isso foram revisados bibliografias que tratam do tema proposto e discorrem sobre o assunto. Esta pesquisa não traz um estudo ampliado, mas tem a pretensão de destacar as principais mudanças no trabalho do pedagogo e sua atuação na gestão democrática. Nesse contexto este trabalho qualifica-se enquanto sua natureza como uma pesquisa qualitativa e referente ao objetivo como exploratória. Sobre a fundamentação teórica foram discorridos sobre a gestão democrática no espaço escolar destacando suas principais mudanças, o trabalho do profissional de pedagogia no ambiente escolar e suas implicações para a efetivação do ensino- aprendizagem e, por fim o trabalho do pedagogo na efetivação da gestão democrática.

Palavras- chave: Gestão democrática, Pedagogo, Gestão escolar, Ambiente escolar. 


\section{INTRODUÇÃO}

0 debate acerca do trabalho da pedagogia e do profissional desta área nos espaços escolares e extraescolares vem sendo discutido nos últimos anos. Com os avanços tecnológicos e as constantes mudanças sociais e culturais na sociedade, tem-se intensificado mais sua importância no processo da gestão democrática escolar. O pedagogo passou a atuar nas comunidades, instituições e demais locais que não se restringem apenas aos espaços da educação formal.

Essas mudanças causou transformações no jeito de ensinar e na forma de organizar a escola. Além disso, também impactou a forma e o jeito de pensar no processo de gestão democrática. 0 pedagogo enxergando e passando a compreender diferentes realidades culturais as quais a escola está inserida, tornou-se um mediador e agente para efetivação de uma gestão que passa a incluir todos no processo das atividades escolares.

Portanto, com a finalidade de observar esta realidade, é objetivo deste trabalho analisar a atuação do pedagogo no processo de gestão democrática enfatizando a descentralização do seu trabalho e como ele passa a envolver todos os sujeitos com o objetivo de formar e promover cidadãos críticos.

Para tanto, com o intuito de fundamentar nossa pesquisa, recorremos a autores como Libâneo (2008), Veiga (1985), Giancaterino (2010) e Said (2009), que ajudaram aprimorar os estudos sobre o tema.

\section{METODOLOGIA}

Esta pesquisa apresenta-se com uma abordagem qualitativa, que se direciona para uma investigação subjetiva tendo foco no procedimento e na reflexão. Nesta abordagem é possível "proporcionar mais informações sobre o tema, facilitando a delimitação do mesmo, bem como, a fixação dos objetivos". (Prodanov e Freitas, 2013).

Do ponto de vista objetivo caracteriza-se como exploratória por proporcionar mais informações sobre o tema, facilitando sua delimitação, bem como, a fixação dos objetivos. (PRODANOV e FREITAS, 2013). Dessa forma a pesquisa apresenta e abrange diversos aspectos. Quanto aos procedimentos, classifica-se como bibliográfica ao propor a análise de vários arranjos acerca do problema estudado, permitindo ao pesquisador uma cobertura mais ampla. (GIL, 2002).

Como método de coleta e análise de dados será empregado à pesquisa bibliográfica que tem como objetivo examinar os pontos de vista e estender as discussões sobre a operacionalização bem como a funcionalidade e os desafios que o gestor escolar enfrenta. Deste modo será possível obter uma análise com qualidade sobre o tema tratado.

\section{GESTÃO DEMOCRÁTICA NA ESCOLA}

As constantes mudanças, políticas, econômicas, tecno- científicas, culturais e sociais pelas quais o mundo tem passado, tem afetado direta e indiretamente nossa organização social e com ela nossa gestora de todo esse processo que é a escola. Sabemos que esta, historicamente, passou e passa por diversos processos em sua construção. Construção essa, que se torna diária, pois ao analisar observamos que cada mudança social é reproduzida e produzida no ambiente escolar.

Padronização de formas, hierarquia de atividades, formação em massa dos sujeitos, tudo isso homogeiniza a escola, traz a ela um modelo difícil de ser quebrado, porque foi enraizada em sua cultura. A escola é vista como um modelo a ser seguido, mas qual será esse modelo?

Se as transformações estão à nossa volta, cabe a nós, observamos isso e encaixarmos na realidade escolar. Quando falo, nós, está inclusa toda a sociedade, pois de forma direta e (ou) indireta estamos ligados ao ambiente escolar. A escola é um todo e o todo faz parte, portanto devemos estar presentes.

A constituição de 1988 quebrou algumas barreiras burocráticas para que a escola se torna-se mais inclusiva e mais democrática:

Art. 205. A educação, direito de todos e dever do Estado e da família, será promovida e incentivada com a colaboração da sociedade, visando ao pleno desenvolvimento da pessoa, seu preparo para o exercício da cidadania e sua qualificação para o trabalho.

Art. 206. 0 ensino será ministrado com base nos seguintes princípios: 
I - igualdade de condições para o acesso e permanência na escola;

II - liberdade de aprender, ensinar, pesquisar e divulgar o pensamento, a arte e o saber;

III - pluralismo de idéias e de concepções pedagógicas, e coexistência de instituições públicas e privadas de ensino;

IV - gratuidade do ensino público em estabelecimentos oficiais;

V - valorização dos profissionais da educação escolar, garantidos, na forma da lei, planos de carreira, com ingresso exclusivamente por concurso público de provas e títulos, aos das redes públicas;

VI - gestão democrática do ensino público, na forma da lei;

VII - garantia de padrão de qualidade.

Assim sendo, apesar de ter sido em uma época de recessão econômica, ainda, sim, a educação foi resistência, e o trabalho da gestão escolar debatido de acordo com suas práticas. Nesse sentido, também é importante lembrar que o significado de gestão, deve ser amplo, precisa abarcar todas as suas funcionalidades sendo aberto ao diálogo e a democracia. Como cita Ferreira (1999: 1241)

Gestão significa tomar decisões, organizar, dirigir as políticas educacionais que se desenvolvem na escola comprometidas com a formação da cidadania [...] é um compromisso de quem toma decisões - a gestão - , de quem tem consciência do coletivo - democrática -, de quem tem responsabilidade de formar seres humanos por meio da educação.

E pensar em gestão nos remete a sua organização por segmento, qual a finalidade e o papel de cada membro nesse processo. Quando se fala em gestão democrática, não se remete a um coletivo tomando decisões aleatórias sem norteamento, significa que cada pessoa envolvida possui uma função e que as decisões são tomadas coletivamente. A escola, portanto, sendo espaço para a democratização, propagadora de conhecimento e também do diálogo, torna-se mediadora entre sujeito e sociedade. Portanto,

[...] na medida em que a gestão democrática (colegiada) define coletivamente as ações e as concepções da escola, ela passa a constituir-se numa condição determinada e determinante de uma teoria e prática progressista de educação, principalmente, quando essa gestão vem como uma necessidade histórica. ( TAQUES et. al. p.4, 2012)

Existe a figura do diretor, que passa a ser visto como figura autoritária e centralizadora de poder, aquele que toma todas as decisões e carrega consigo um valor hierárquico. Mudar essa situação, vai além do comportamento discursivo, está ligado a um plano de gestão que passe efetivamente a ter outra postura, e que seja construído com bases sólidas. Paro (2005) discorre sobre o papel do diretor ao afirmar que:

Em termos práticos, as atividades de direção restringem-se ao diretor - e aos assistentes de diretor, sem coadjuvante no comando da escola. Mas estes também acabam se envolvendo em atividades rotineiras que pouco têm a ver com uma verdadeira coordenação do esforço do pessoal escolar com vistas à realização de objetivos pedagógicos. Concorrem para isso, em grande medida, as precárias condições de funcionamento da escola (...). Diante desse quadro, não é difícil imaginar as dificuldades da direção em coordenar esforços de pessoas cujas atividades dependem de recursos inexistentes. (PARO, p. 73-74, 2005)

No entanto, na gestão democrática cada um tem seu papel, não existe tomadas de decisões isoladas, a comunicação precisa ser horizontal, dialógica e participativa, tendo destaque o trabalho do pedagogo, que passa a ser um mediador no processo da gestão democrática. Este profissional tem o domínio de formas e métodos através dos quais se realiza os processos de formação cultural e social.

\section{O TRABALHO DO PEDAGOGO NA GESTÃO ESCOLAR}

As práticas educativas são interligadas com as práticas sociais, econômicas, políticas e culturais e, portanto, nesse meio, a pedagogia exerce o papel de estudar as práticas educativas tendo em vista propor finalidades e objetivos no direcionamento de ações que visem funcionalidade do ambiente escolar. Sua função está para além dos muros escolares, envolvendo comunidade e sociedade de forma geral, por isso é visto como 
mediador, ele está em diferentes espaços efetivando uma educação de qualidade e uma formação crítica dos sujeitos. Para Gadotti (2004), "o pedagogo é aquele que não fica indiferente, neutro, diante da realidade".

Dessa forma, na construção do plano político pedagógico, o pedagogo deve ter cautela, conhecer a realidade a qual a escola está inserida, envolver a comunidade e identificar quais as dificuldades do corpo discente e docente, bem como da comunidade, que impedem a escola de desenvolver seu plano pedagógico. Libâneo (2008) salienta que:

0 trabalho em equipe é uma forma de desenvolvimento da organização que por meio da cooperação, do diálogo, do compartilhamento de atitudes e de modos de agir, favorece a convivência, possibilita encarar as mudanças necessárias, rompe com as práticas individualistas e leva os alunos a produzir melhores resultados de aprendizagem. (LIBÂNEO, 2008, p. 383)

Entretanto, o mesmo autor ressalta (2008) que de pouco adianta todo o planejamento se não for bem executado, e se os objetivos da aprendizagem não forem alcançados. É preciso lembrar também, que toda essa carga de responsabilidade não deve recair, apenas, no pedagogo. 0 trabalho é em conjunto e todos com suas funções. Assim, na gestão democrática, é necessário a participação de todos, havendo a divisão de tarefas e responsabilidades, caso contrário, um membro irá ficar sobrecarregado dificultando alcançar o resultado desejado.

O pedagogo, portanto, irá agir conforme o pensamento democrático, planejar e organizar uma equipe que troque opiniões, planeje em conjunto, procurando meios para concretizar o ensino- aprendizagem na formação de cidadãos críticos. Como cita Libâneo (1985):

Democratizar o ensino é ajudar os alunos a se expressarem bem, a se comunicarem de diversas formas, a desenvolverem o gosto pelo estudo, a dominarem o saber escolar; é ajudá-los na formação de sua personalidade social, na sua organização enquanto coletividade. Trata-se, enfim, de proporcionar-lhes o saber e o saber-fazer críticos como pré-condição para sua participação em outras instâncias da vida social, inclusive para melhoria de suas condições de vida. (LIBÂNEO, 1985, p.12)

\section{PEDAGOGO E GESTÃO DEMOCRÁTICA}

Diante do que já foi discorrido, faz-se necessário salientar que o exercício de uma gestão democrática efetiva, baseia-se nas transformações sociais, culturais, políticas e econômicas. Além disso, há também a inserção e constante absorção de informação através das novas tecnologicas. Essa realidade tem influenciado direta e indiretamente o jeito e a forma de fazer educação. 0 pedagogo, como agente, tem a responsabilidade de filtrar tudo isso na efetivação do plano pedagógico.

Said (2009) afirma que as mudanças tecnológicas reorganizaram o trabalho dos profissionais da educação, levando o processo educativo para além dos muros escolares e redefinindo o espaço de atuação do pedagogo. Sendo este profissional levado a participar do processo de formação humana, fora do ambiente escolar.

A escola mudou e ganhou novos espaços, não se pode mais pensar a escola como único local de ensino. As tecnologias se expandiram e passaram a ser ferramentas poderosas na absorção de conhecimento. Trazêlas para a sala de aula não é apenas um desafio do professor, mas também de todo corpo escolar, inclusive do pedagogo. Diante disso, a forma de fazer e se olhar a gestão democrática mudou.

Pensar na gestão democrática implica ampliar os horizontes históricos, políticos e culturais em que se encontram as instituições educativas, objetivando alcançar a cada dia mais autonomia. Quando falamos em autonomia, estamos defendendo que a comunidade escolar tenha um grau de independência e liberdade para a coletividade pensar, discutir, planejar, construir e executar seu projeto político pedagógico, entendendo que neste está contido o projeto de educação ou de escola que a comunidade almeja, bem como estabelecer os processos de participação no dia-a-dia da escola. (BRASIL, 2004, p. 46).

0 pedagogo, que hoje, se encontra com mais desafios, tem a missão de propor e planejar uma gestão que vise interligar sociedade, comunidade e todo o corpo escolar. É um desafio que não pode ser feito só e é isso um dos pré requisitos para uma gestão efetivamente democrática. 
A democracia já é uma palavra que significa participação. Porém, apenas opinar e expressar opinião, não é democracia, é preciso que cada segmento que faça parte do ambiente escolar execute suas funções com responsabilidade e zelo. Ao pedagogo cabe a função de direcionar e ter o apoio de todos, sem que precise dar ordens. Nesse sentido Veiga (1995) ressalta que:

Para a construção do projeto político-pedagógico seja possível não é necessário convencer os professores, a equipe escolar e os funcionários a trabalhar mais, ou mobilizá-los de forma espontânea, mas propiciar situações que lhes permitam aprender a pensar e a realizar o fazer pedagógico de forma coerente.(VEIGA, 1995, p. 15)

0 pedagogo, é o profissional que lida com o humano, com as diferentes formas e culturas da sociedade. Ele pesquisa e entendi as necessidade de todos os segmentos que fazem parte do ambiente escolar. Entende as necessidades dos alunos, pais, professores e comunidade, procurando identificar quais as dificuldades. Assim consegue propor melhorias tanto internas como externas. Desse modo torna-se um agente transformador propondo soluções para diversas situações.

Por fim, é preciso compreender que com as transformações causadas pelas novas tecnologias, a função do profissional de pedagogia ganhou novos espaços e sua atuação não se restringe apenas aos muros da sala de aula, também é preciso enxergar que esse profissional é de suma importância para o processo efetivo da gestão democrática. Como cita Roberto Giancaterino (2010):

0 processo de defesa do ideal democrático necessita de uma valorização de seus recursos humanos, educando a todos sem distinção, de reconhecer a existência de vasta gama de diferenças individuais, de modo que o processo de ensino e aprendizagem deve ser revitalizado, adaptando-se aos velhos métodos, ao passo que novos são criados. (GIANCATERINO, 2010, p.77).

\section{CONCLUSÃO}

Diante do que foi discutido neste trabalho, é preciso enfatizar que o profissional da pedagogia tem uma grande responsabilidade e um trabalho primordial na formação da gestão democrática. Sua função ultrapassou os corredores escolares, está nas comunidades, instituições e no seio familiar daqueles que fazem parte do ambiente escolar.

A gestão democrática ganhou novas formas, estabeleceu novos parâmetros e passou a atuar, também, dentro do universo tecnológico. Este que também faz parte do trabalho do pedagogo. Tudo deve ser feito em conjunto, não apenas pensando, mas efetivando todo o plano plano político e pedagógico que deve ser traçado através de uma comunicação horizontal, democrática e participativa.

Como bem ressalta Libâneo (1985) é o trabalho coletivo que expande os horizontes e faz a gestão democrática ser efetiva, pois é preciso formar sujeitos críticos, seres pensantes, capazes de opinar sobre os mais diversos tipos de assuntos para que possam transformar a realidade a qual estão inseridos.

0 pedagogo lida diretamente com as pessoas, têm a capacidade de transformar suas realidades e dentro de todo esse processo passa ser agente, mediador, na função de trazer autonomia para a comunidade escolar. Autonomia esta, que está ligada a participação de pais, líderes comunitários e sociedade em geral. Portanto, é preciso compreender e entender a importância deste profissional, assim como é preciso que o poder público dê subsídios e estrutura para que seu trabalho seja melhor executado. 


\section{REFERÊNCIAS}

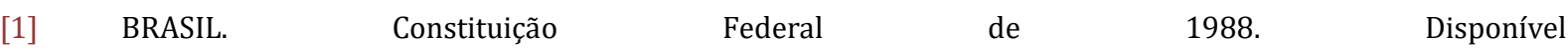
em:http://www.planalto.gov.br/ccivil_03/Constituicao/Constitui\%E7ao.htm

[2] BRASIL. Ministério da Educação. Secretaria de Educação Básica. Programa Nacional de fortalecimento dos Conselhos Escolares. CADERNOS, 2004.

[3] FERREIRA, N. S. C. Repensando e ressignificando a gestão democrática da educação na "cultura globalizada". In: Educação e Sociedade. Campinas. Vol. 25, n. 89, Set/dez, 2004.

[4] GADOTTI, M. Pedagogia da práxis. Sâo Paulo: Cortez, 2004.

[5] GIANCATERINO, Roberto. Supervisão escolar e gestão democrática: um elo para o sucesso escolar. Rio de Janeiro: Wak Ed., 2010.

[6] GIL, Antônio Carlos. Como Elaborar Projetos de Pesquisas. São Paulo: Editora Atlas, 2002.

[7] PARO, Vitor Henrique. Gestão Democrática da escola pública. 3a edição. São Paulo: Ática, 2005.

[8] PRODANOV, Cleber Cristiano; FREITAS, Ernani Cesar de. Metodologia do Trabalho Científico: Métodos e Técnicas da Pesquisa e do Trabalho Acadêmico. Novo Hamburgo: FEEVALE, 2013.

[9] SAID, Isabel Magda Pierre Carneiro. Pedagogia e Pedagogos em Diferentes Espaços: interdisciplinaridade e competência pedagógica. 2009. Disponível no site: http://www.socultura.com/index.php. Acesso em 06/11/10.

[10] TAQUES, Mariana F. et al. O papel do Pedagogo na Gestão: possibilidades de mediação do

[11] currículo. Disponível em: http://www.nre.seed.pr.gov.br/londrina/arquivos/File/4opapeldopedagogo.pdf. Acesso em 25/05/2012.na "cultura globalizada”. In: Educação e Sociedade. Campinas. Vol. 25, n. 89, Set/dez, 2004.

[12] VEIGA, Lima Passos Alencastro. A Prática Pedagógica do professor de Didática. São Paulo. Papirus. 1989.

[13] LIBÂNEO. José Carlos. Organização e gestão da escola: teoria e prática. 5 ed. Goiania: MF Livros, 2008

[14] LIBÂNEO, J. C. Democratização da Escola Pública: A pedagogia crítico-social dos conteúdos. São Paulo: Loyola Brasil, 1985. 


\section{Capítulo 2}

Práticas e desafios da gestão escolar: No contexto da educação pública municipal e interferências políticopartidárias

\section{Regina Chaves dos Santos}

Resumo: Por gestão escolar entende-se o conjunto de ações necessárias ao bom desenvolvimento das práticas educacionais, em seu corpo, e logística. A contento, desafiador ao papel de gestor que busca promover uma gestão escolar participativa integrando-se ao dossiê de saberes didático-pedagógico de ensino, junto aos conhecimentos ora administrados, também trazido pelos seus alunos. Entendendo, que se encontra na educação a base de formação social do ser humano amparado pela Constituição Federal Brasileira e leis reguladoras como a LDB - Lei de Diretrizes e Base da Educação. A saber, a necessidade de formar o indivíduo com valores, haja vista, da educação constituir-se o elo propiciador para a construção e desenvolvimento do saber humano, estando na escola, o espaço de socialização de conhecimento. Diante as práticas e desafios da gestão escolar pública encontra-se dificuldades para o pleno desenvolvimento de uma gestão democrática, participativa e autônoma além, de limitantes recursos didáticos-pedagógicos e tecnológicos a carência de formação continuada, vértice, ao bom desempenho da educação e vivência global do aluno as aprendizagens. Indispensável, ao processo educacional, estão a tríade: escola, família e estado a formarem elos propiciadores a educação ainda que existam nichos de desigualdades sociais o aluno deve ser alcançado. Tal estudo versa pelo objetivo de buscar compreender a gestão escolar pública e seu corpo de apoio (pouca efetivação), por indicação político-partidária tolhendo a comunidade de participarem na escolha do gestor democraticamente, quiçá, da própria autonomia do gestor escolar frente ao processo educacional. Do referencial teórico-metodológico via pesquisa bibliográfica, obteve-se, resultados ainda excipientes.

Palavras-chave: gestão escolar pública, função social da educação, CFB 1988, tríade, interferência político partidária. 


\section{INTRODUÇ̃̃o}

"Na hierarquia dos problemas de uma nação, nenhum sobreleva em importância, ao da educação" ("Manifesto de 1932 e 1959", - Haddad, Nunes p. 9, Coleção Educadores - MEC, 2010, - Anísio Teixeira).

Em presença das práticas e desafios da gestão escolar pública na sociedade contemporânea, induz-se que o gestor escolar seja um sujeito empático, versátil e proativo no desempenho de suas atribuições para com a educação, em todas os blocos, de seu desenvolvimento. Urge-se, pensar numa educação contemplativa aos anseios da sociedade, aonde, o processo educacional de ensino-aprendizagem atrelado as inovações tecnológicas e outros possam corroborarem para uma educação em movimento e de boa qualidade. Incumbindo assim, da gestão escolar, o desafio de cumprir com sua função social na formação dos estudantes, equânime as aprendizagens e gestão dos recursos humanos e logística.

Por quanto, a gestão escolar democrática enquanto instrumento otimizador dentro da esfera educacional, visa diferenciar as políticas educacionais de forma mais democrática gerindo-a na visão do "todo," a melhorar a eficiência de ensino, ao mesmo tempo em que assegura uma desburocratização das atividades cotidianas. Busca-se, operacionalizar o entorno do trabalho pedagógico, da gestão da escola e das políticas educacionais em suas diretrizes, ao geri-las, a favor de melhorias no conjunto.

Encontra-se em Brasil (2013, p. 55), das diretrizes curriculares nacionais da educação básica insta-se, da obrigatoriedade da gestão democrática no ensino público, assegurado pelo artigo 3 o da LDB e inciso VIII, também os artigos 12 e 13 preveem decisões coletivas, ainda que desafiador mesclar a prática com a realidade versado ao que se estabelece a lei e o que de fato se faz no exercício do poder. Tão logo, a participação da comunidade nos adventos da gestão escolar zelando pelos princípios e finalidade mediante as incumbências delegadas ao sistema de ensino e gestão assim como das práticas, ideias e concepções pedagógicas envolventes.

“[...] a gestão democrática é entendida como princípio que orienta os processos e procedimentos administrativos e pedagógicos, no âmbito da escola e nas suas relações com os demais órgãos do sistema educativo de que faz parte" (BRASIL 2013, p. 56).

Embora desafiador a função do gestor escolar em estabelecer uma gestão democrática, envolvente e participativa nos encargos pedagógicas e diversidade de ideias abarcadoras ao papel delegado a educação e ministrado pela gestão democrática a alcançar sua função social nos parâmetros da educação constituinte, participativa e cidadã. Ora, da interação de seu corpo pedagógico e afins a participação da família e especialmente do próprio aluno enquanto ator principal deste processo, mediado, na sua aptidão de "aprender a aprender" a desenvolver-se de forma global mediante a formação cidadã, - em uma leitura de mundo, sociedade e culturas constituindo a sua identidade e se consolidando intelectualmente e como pessoa.

Destarte, o gestor escolar (gestores no sentido de envolvimento entre a prática educacional e a ambientação - corpo docente), assume um papel relevante na condução de processos que envolvam a vida escolar, necessitando assim, manter uma visão proativa para gerir a educação e administrá-la, além de lidar com as políticas e ações que envolvam todo o corpo escolar. Um bom planejamento versado em metodologias didático-pedagógicas contemplativo das realidades vivenciadas pela comunidade da educação.

Tão logo, objetiva-se problematizar das interferências político-partidária em meio as instituições públicas de ensino básico, de parte, dos municípios brasileiros. Para tanto, busca-se também, compreender da gestão escolar pública e seu corpo de apoio (pouca efetivação), no lócus da indicação político-partidária, a qual, supostamente tolhem da comunidade o seu direito de participação democrática na escolha do gestor educacional, quiçá, da própria autonomia desse gestor frente ao processo educacional.

Na perspectiva da gestão democrática ora desvirtuada por interferências no ambiente de trabalho pela voz de grupos políticos em que estão inseridas, aposseando-se, da estrutura organizacional e controle no desempenho das funções pelos servidores, encabrestados, a cartilha. Corroborando para o desenrolar da temática, este estudo, apoia-se em referenciais teóricos ainda escasso nas literaturas, mas capaz de validar o lócus da pesquisa ainda, despertar leitores e pesquisadores para a importância de conhecer para si posicionar, - elevar a voz. 
Assim, Zerbini (2012, p. 11), adverte sobre “a intervenção política na gestão escolar" a produção de lastros organizados e historicamente contemplativos de clientelismo via designação do diretor escolar, no aspecto alicerçado da política versada do favoritismo e marginalização das oposições, - da retirada de direito da escolha democrática pela comunidade escolar e da incoerência em atrelar competência de gestão ao marco da indicação política.

Corroborando com tal visão Ribeiro, Chaves (2012, p. 4 apud DOURADO, 2006, p. 79), exorta da gestão democrática se alinhar ao "processo de aprendizado e de luta política que não se circunscreve aos limites da prática educativa, mas vislumbra, nas especificidades dessa prática social e de sua relativa autonomia", e da "possibilidade de criação de canais de efetiva participação e de aprendizado do "jogo" democrático e consequentemente, do repensar das estruturas de poder autoritário que permeiam as relações sociais e, no seio dessas, as práticas educativas." Pressupõe-se de que o processo de gestão não seja tão democrático, tão livre, tão autônomo para os seus gestores quando estes se submetem a escolhas politiqueiras. Ainda que a Constituição Federal 1988, elevasse os municípios à condição de entesfederados delegando-lhes o direito de organização de seus aparelhos de ensino pela autonomia político-pedagógica, administrativa e financeira, também, a LDB 9394/96 reforçasse tal entendimento permitindo aos municípios definirem suas normas para com a gestão democrática na esfera do ensino público. Referente ao encargo dos municípios em agir com responsabilidade diante às políticas públicas da educação, Santos, Prado (2018, pp. 60-61 apud NARDI et al, 2013, p. 177), entretanto, "pode-se, produzir tanto melhorias quanto atrasos em termos de democratização da gestão educacional em nível de sistema e de escola", os avanços podem serem minados ao tempo que se mantem a aparência de uma gestão democrática, ora, de cunho patrimonialista.

Todavia, este artigo justifica-se pela relevância social a que se trata o assunto, ora, dissimulado em virtude de algum poder político "ditatorial" em curso, na hipótese de se perpetuar no poder, ainda que desvirtuem, - a importância da sociedade em participar de ações inerentes ao campus educacional e decisões conexas. Por quanto, visa-se despertar o cidadão oriundo de uma sociedade negligenciada ao seu direito de participação, haja vista, tais inferências vezes passarem despercebidas, mas propositalmente perpetuadas em favorecimento de títulos político-partidários.

\section{METODOLOGIA}

Para este estudo utilizou-se de referenciais bibliográficos (livros e Web), optando pela pesquisa bibliográfica, haja vista, das dificuldades do momento de pandemia do Covid - 19, em fazer-se um estudo detalhado da articulação antidemocrática praticada pelo poder político municipal em grande parte dos entesfederados brasileiro.

De acordo com (CAMPOS 2004, p. 36), a palavra método origina-se do grego, trazendo o sentido de: "como percorrer ao longo de um caminho" e se assim for, - o método da pesquisa cientifica dá a entender que é preciso adentrar a este caminho pela busca incessante para com a resolução do problema exposto ao processo investigativo.

Ainda, Conforme (CAMPOS 2004, pp. 113-115), o pesquisador precisa considerar entre os elementos da pesquisa a escolha do material enquanto elemento indispensável ao andamento do seu objeto de pesquisa. Ainda, avaliar seu nível de mensuração, fidelidade, validade, precisão, adequação aos sujeitos, ou seja, provir de uma análise psicrométrica das medidas seletas. Após, a escolha e coleta de material probatório ao campus de estudos.

\section{REFERENCIAL TEORICO}

\subsection{DA GESTÃO DEMOCRÁTICA E SEUS PARES}

Entende-se por gestão democrática da educação a capacidade de gerir com responsabilidade e autonomia conforme versa da Constituição Federal Brasileira 1988, em Artigo 206, inciso VI, o qual, trata-se da importância em primar por uma gestão democrática na educação e obrigatoriedade de fornecê-la sem outros apelos, - em todo campus de ensino. Corroborando (BRASIL, 2013, pp. 54-55), a Lei de Diretrizes e Bases da Educação - LDB, no. 9.394/96, inciso VIII do artigo 3ํo e artigos 12 e 13 incisos), prevê a gestão democrática como princípios norteadores, logo, a escola precisa ser organizada e administrada em sincronia entre seus pares, - na inter-relação, equânime, ao desenvolvimento proativo da matriz educacional e afins bem como da organização do trabalho pedagógico e da gestão escolar. 
De tal forma, baseando-se em (PARO, 2001, pp. 51-52), o gestor educacional deve trabalhar na perspectiva do coletivo em razão do social, implicado, na formação de cidadãos independentes e pautado em princípios de colaboração e solidariedade, a dispor-se, pela ética e liberdade indispensáveis a educação de qualidade, ante a proficiência em educação. Para tanto, a democracia faz parte de um processo intrínseco a prática política e a educação faz parte dessa esfera, haja vista, a democracia necessitar de nuances da cultura de seu povo, "aprovação", para com este regime. Tratando assim, da importância de a escola ter entre os objetivos da educação, a formação continuada de seus colaboradores, baseado, em pressupostos de liberdade, equidade ao pronto pedagógico, formação cidadã e colaboração mútua, - favoráveis a democracia e as razões didático-pedagógicas para a função social a qual, a educação pleiteia. Ainda,

"[...] para dar conta de seu papel, a gestão escolar precisa ser, pelo menos, duplamente democrática. Por um lado, porque ela se situa no campo das relações sociais onde, [...] torna-se ilegítimo o tipo de relação que não seja de cooperação entre os envolvidos. Por outro, porque [...] a característica essencial da gestão é a mediação para a concretização de fins; sendo seu fim a educação e tendo está um necessário componente democrático, é preciso que exista a coerência entre o objetivo e a mediação que lhe possibilita a realização, posto que fins democráticos não podem ser alcançados de forma autoritária" (PARO 2001, p.52).

No lastro da gestão democrática é indispensável a cooperação de seus pares, haja vista, pertencer ao nicho das relações sociais, ao mesmo tempo, que se faz em função do processo educacional. Logo, a gestão educacional democrática deve possuir, como plano de fundo, - autonomia ${ }^{1}$, coerência, versatilidade, liberdade de gestão e acima de tudo, implicada, com o desenvolvimento da aprendizagem do seu alunado e condução da equipe pedagógica.

\subsection{DA RELAÇÃO DO GESTOR ESCOLAR}

Para que ocorram ações transformadoras em cada campo educacional é preciso haver reflexão e envolvimento na própria forma de fazer educação, ou seja, pensar a instituição enquanto ambiente pedagógico envolto ao desenvolvimento global do estudante em seu meio; buscar conhecer a "vida" da comunidade escolar; criar estratégias executáveis ao coletivo; e, acima de tudo, é importante que o gestor escolar se policie da sua função "hierárquica", de que, estar no cargo de gestor escolar exige de si maior proficiência, logística e recursos humanos além, de conhecimentos didático-pedagógicos e gestão para lidar com as "regras", ora, já cristalizadas no ambiente, mas que necessita de uma visão diferenciada; ter jogo de cintura, ser empático aos olhares e visionário de uma educação continuada, inovadora, pedagógica e centrada no aluno enquanto ator de conhecimentos e disseminador deles (seus saberes - vivências, culturas...); e, ciente dos constantes desafios e apto a estratégias de superação.

Na Constituição Federal de 1988, versa:

“Art. 205. A educação, direito de todos e dever do Estado e da família, será promovida e incentivada com a colaboração da sociedade, visando ao pleno desenvolvimento da pessoa, seu preparo para o exercício da cidadania e sua qualificação para o trabalho" (Jus Brasil, 2020).

Por assim dizer, é papel do gestor escolar corroborar para harmonização do ambiente dentro e fora dos muros da escola, haja vista, a educação se fazer entre a escola e o ambiente familiar. Implicar-se em dimensões axiológicas e delegar aos seus colaboradores praticas pedagógicas exequíveis, para quê, o estudante em seu lócus esteja apto a problematizar os conhecimentos a se desenvolver com liberdade e autonomia para com os estudos e mais, para consigo mesmo, em seu estar consciente, de seu papel, na sociedade. Logo, o desenvolver das políticas educacionais e outras parcerias possibilita a gestão escolar obter melhores resultados, haja vista, o processo educacional não se fazer mais pelo uso de giz e quadro negro. É preciso, inovação para fazer e vivenciar a educação entre outros, apostar na inclusão digital dos alunos, incorporar a educação remota as práticas pedagógicas levando em conta o fator de desigualdades

1 Não é para o diretor apenas seguir normas e regimentos, mas que se organize a educação diante a parâmetros da educação nacional e realidade de seu público - a escola é um espaço coletivo de discursões, elaborativo, e/ou provável de educação. 
sociais, considerável, na sociedade brasileira. A saber, é indispensável acolher as vivências do aluno e o jeito dele interagir com as informações: desconstruir, dialogar, interpretar - fazer educação. Para que resultados apareçam para além das estatísticas do IDEB - Índice de Desenvolvimento da Educação Básica.

Precisa-se que o professor enquanto mediador do conhecimento se deixe afetar pelos saberes sociais do seu aluno (compreender - falar a língua do aluno - pôr-se em seu lugar - desenvolver empatia), se conecte ao momento das vivências. Considerando ainda, que parte do alunado venha a possuir "mais acesso" as informações digitalizadas (não são conhecimentos), do que seu próprio professor. Importante que as tecnologias sejam usadas para agregar conhecimento, é uma ferramenta instantânea de informação, da pesquisa, da interação entre outros não sendo mais cabido a escola gerenciar a estrutura pedagógica do conhecimento, haja vista, ela ser muito mais dinâmica e interpretativa.

Cabendo para tanto, o uso de uma didática intermitente as metodologias de ensino para que juntos (direção, professor, coordenação, aluno), possam aproveitar da interação de saberes, transformando-os, em aprendizados e remoção de dúvidas ao tempo que enriquece as vivências e dialoga com os saberes - visando um pleno desenvolvimento das aprendizagens ao instrumentalizar a formação dos estudantes, ajudando a se tornarem, indivíduos de si no universo do coletivo.

Lembrando que a escola é um espaço coletivo de discursões afirmativas do conhecimento, ou seja, é uma junção entre o espaço físico e a simbólica representação de desenvolvimento do ensino-aprendizagem. Haja vista, o espaço que se oferta aos estudantes para com a dimensões do conhecimento, ajudando-os, a se desenvolverem para o exercício pleno da cidadania, direitos, deveres entre outros a viverem em sociedade.

\subsection{COMO ACONTECE A GESTÃO DEMOCRÁTICA?}

Está é uma pergunta embaraçosa, por conta de muitos fatores incluindo a intersubjetividade entre a equipe (recursos humanos). Por quanto, situar a escola na contemporaneidade é o primeiro passo para uma gestão democrática de finco coletivo, logo, importante que esteja aberta a comunidade e pronta a dinamizar dos recursos financeiros, materiais e humanos. Em vista disso, o bom rendimento pedagógico e qualidade da educação fundamentam todo o processo.

Importante, que a escola mantenha políticas de formação continuada em prol de um ensino contemplativo, capaz, de desenvolver vínculos afirmativos entre a direção e o seu corpo pedagógico, ora, voltados para o alunado. Em lócus, é indispensável que o processo de aprendizagem aconteça de acordo com as etapas do desenvolvimento cognitivo e interação social do aluno. É importante frisar que para uma educação equânime é preciso que vários fatores funcionem bem e estes fatores se encontram entre o pedagógico com sua metodologia e didática de ensino em parceria com a escola e a família conexo aos interesses do estudante. Ainda, pelo fato, de sempre haver inovações (via sociedade contemporânea), o professor não deve ficar retrógado nem com o seu comportamento e muito menos, para com a didática do ensino.

Porquanto, o que autoriza os desajustes em parte das escolas municipais públicas em nosso país não é somente o cargo de indicação político-partidária que às vezes, deixam de levar em consideração a capacitação pedagógica, logística e relações humana de seus gestores e do corpo docente (ora, com formação insuficiente), mas também o desconhecimento da própria comunidade. Em meio a um simulacro de legalidade em prol de um sistema político, ora, arbitrário ao tempo que "necessário" para perpetuarem no poder, ainda que causem prejuízos ao processo educacional. Porquanto, o cargo de gestor deve estar em consonância com todos os seus atores, com a formação dos alunos e, - em pleno exercício da democracia.

\subsection{VIÉS DA INTERFERÊNCIA POLÍTICO-PARTIDÁRIA}

Creditar a gestão escolar aos instrumentos de ação concernente ao seu papel no processo educacional desde a formação continuada dos seus funcionários - visando um melhor desempenho na formação educacional e social dos estudantes e interação com o coletivo, ela, precisa ser entendida como um instrumento de participação coletiva para obtenção de melhores resultados no conjunto da educação.

Por conseguinte, Zerbini (2012, p. 11), infere-se que: “a intervenção política na gestão escolar produz lastros organizados e historicamente contemplativo as formas mais frequentes de clientelismo através da designação do diretor escolar, no aspecto alicerçado da política versada do favoritismo e marginalização das oposições". Ainda, "tais influências retiram o direito da escolha democrática pela comunidade escolar além, da incoerência em atrelar competência de gestão ao marco da indicação política na escolha do diretor escolar. Avigora, na maioria dos casos a conservação da ingerência e do clientelismo na rotina escolar, além de estereotipar a comunidade escolar da escolha". Lembrando, que "a autonomia da escola versa da gestão 
democrática constituintes de exigências histórico-sociais impetradas mediante ao desenvolvimento da sociedade", haja vista, a educação no lócus da prática social vem passando por processos de transformações significativas, donde a gestão da escola pública impreterivelmente, necessita envolver, - comunidade local e escolar em prol da educação.

Em Ribeiro, Chaves (2012, p. 4 apud DOURADO, 2006, p. 79), infere-se de que a gestão democrática se alinhe ao "processo de aprendizado e de luta política que não se circunscreve aos limites da prática educativa, mas vislumbra, nas especificidades dessa prática social e de sua relativa autonomia", haja vista, da "possibilidade de criação de canais de efetiva participação e de aprendizado do "jogo" democrático e consequentemente, do repensar das estruturas de poder autoritário que permeiam as relações sociais e, no seio dessas, as práticas educativas." Entendendo assim, que o processo de gestão não seja tão democrático, tão livre, tão autônomo para os seus gestores quando estes se submetem a escolhas politiqueiras. Ainda que a Constituição Federal 1988, elevasse os municípios à condição de entesfederados delegando-lhes o direito de organização de seus aparelhos de ensino pela autonomia político-pedagógica, administrativa e financeira e, a LDB 9394/96 reforçasse tal entendimento permitindo aos municípios definirem suas normas da gestão democrática na esfera do ensino público.

Referente ao encargo dos municípios em agir com responsabilidade diante às políticas públicas da educação, Santos, Prado (2018, pp. 60-61 apud NARDI et al, 2013, p. 177), exorta que: "pode-se, produzir tanto melhorias quanto atrasos em termos de democratização da gestão educacional em nível de sistema e de escola". Ainda, os avanços podem serem minados ao tempo que se mantem a aparência de uma gestão democrática, ora, de cunho patrimonialista. Explicando que:

“O gestor patrimonialista, dificilmente tomará decisões com base na objetividade, organização e gestão da unidade educativa, haja vista, encontrar-se extremamente comprometido com as relações tecidas com os seus apoiadores e consequentes eleitores" (SANTOS, PRADO 2018, p. 4 apud ESQUINSANI, 2013, p. 110),

Tão logo, parte, dos gestores escolares e corpo docente advêm de indicações políticas partidárias, as quais, tolhem-lhes de autonomia e mais grave, - do direito da sociedade de contar com uma gestão democrática proficiente em liderança.

\section{RESULTADOS E DISCUSSÕES}

Nota-se, a importância de se aprofundar em estudos, haja vista, deparar com resistências na abordagem da temática. Entende-se que por algum motivo, ainda que "cultural", parte da sociedade brasileira se veem influenciada por tais regimes políticos. Carecendo assim, de um consciente coletivo a dar voz ao campus das políticas públicas da educação, ainda encoberta por governantes promíscuos que de alguma maneira buscam tirar proveitos dessa inercia coletiva a se perpetuarem no poder de forma mandataria.

Entendendo que a gestão escolar democrática é um instrumento valorativo de pertencimento da sociedade democrática aos assuntos educacionais de formação cidadã e para tanto, o gestor escolar deve estar a serviço da função social em uma educação de boa qualidade. Para tanto, verifica-se da importância de mais pesquisas arrolando das interferências político-partidárias no campus da gestão escolar democrática de modo que a sociedade se faça presente a não permitir a naturalização destas ciladas, propositais, divergente a gestão participativa ora, democrática.

\section{CONSIDERAÇÕES FINAIS}

Com base em estudos e observações notou-se que a gestão escolar democrática aparece desfocada entre a prática e a realidade, no lócus, da gestão pública de parte dos municípios brasileiros. Ressaltando, que indicações políticas partidárias para cargos de confiança dominam o cenário das escolas públicas, diminuindo assim, a autonomia do diretor escolar dessas instituições de ensino, ao mesmo tempo, se retira da comunidade o direito de escolha para com uma gestão democrática - autônoma e participativa.

Tais interferências, maculam o significante maior que se busca por meio da educação e de certa forma desvirtuando o papel do gestor escolar e seus pares (quadro de apoio), de estabelecer com liberdade diante ao conhecimento pedagógico; da didática em proferir aulas; de exercer uma relação dialógica (professor X aluno), onde o conhecimento exerça da função libertadora para com o desenvolvimento ser humano, socializado, em sua integralidade. Entretanto, torna-se indispensável entender que a escola pública é um espaço versado para a educação, ou seja, na elaboração e discursão de saberes em prol do desenvolvimento formativo do seu estudante. 
Todavia, quando os interesses políticos partidários se sobressaem no espaço da educação os resultados podem minar a gestão democrática. Doravante, alerta-se para o papel de o gestor escolar e apoio pedagógico a não se colocarem em função de tais interesses, mas a preservar o ambiente escolar enquanto espaço democrático instrumentalizado para o saber, ora, independente no sentido de que a educação não deve servir a "líderes políticos", que usam de suas funções governamentais para intimidar e alienar funcionários públicos. 0 estar do gestor escolar faz-se jus cumprir a função social da educação em face da formação cidadã, exercício da cidadania e qualificação para o trabalho conforme assegura, a CF de 1988.

Doravante, a gestão escolar pública necessita constituir-se nos protótipos da gestão democrática, revertida da participação entre a comunidade escolar e seus pares, além das políticas públicas centradas ao desenvolvimento global do aluno; na tomada de decisões; nos grêmios estudantis; na execução e avaliação dos projetos pedagógicos; e, em ações deliberativas a favor de vertentes educacionais.

Por quanto, é preciso acreditar em uma educação para e com a democracia, - pensada para o cidadão, - o reconhecimento de seus direitos e deveres. A saber, é dever da gestão escolar impelir para que se cumpra com os pareceres da educação afirmando o direito do aluno em se desenvolver por uma educação de qualidade. Em vista, da educação advém o sentimento de pertença, construindo de si mesmo, os alicerces para a vida em sociedade. Porém, do político-partidário a escola carece apenas das políticas-públicas em educação para com o desenvolvimento da aprendizagem escolar e formação cidadã.

\section{REFERENCIAS}

[1] JUS BRASIL. Art. 205 da Constituição Federal de 88 - Jus Brasil.

https://www.jusbrasil.com.br/topicos/1241734/artigo-205-da-constituicao-federal-de 1988. Acesso em: novembro 2019.

[2] Art. 206 - CONSTITUIÇÃO DA REPÚBLICA FEDERATIVA DO .http://www.senado.leg.br/atividade/const/con1988/con1988_04.06.1998/art_206_aspDa Educação. Art. 206. O ensino será ministrado com base nos seguintes princípios: ... VI - gestão democrática do ensino público, na forma da lei. VII - garantia.

[3] BRASIL. Ministério da Educação. Lei de Diretrizes e Bases da Educação Nacional. Lei n.. 9.395/96. Brasília: 1996.

[4] BRASIL. Diretrizes Curriculares Nacionais da Educação Básica. Brasília: MEC, SEB, DICEI, 2013. 562p.

[5] CAMPOS, Luiz Fernando de Lara. Métodos e Técnicas de Pesquisa em Psicologia. Campinas, São Paulo: Editora Alínea, 2004. 154p. 3ª edição

[6] JANDIRA: Ação na Educação. https://educacaojandira.blogspot.com/2011/05/emebdolorespaschoalinfazendo-e-acontecendo.html Acesso em: 01 de setembro de 20.

[7] NUNES, Clarice. Anísio Teixeira - Fundação Joaquim Nabuco - Ministério da Educação - FNDE. Coleção Educadores - MEC. Editora Massangana, 2010.

[8] PARO, Vitor Henrique. Escritos Sobre Educação (2001). Editora: Xamã. 150 pag. em PDF. http://www.vitorparo.com.br/wp-content/uploads/2019/10/Escritos-sobre Educação \%C3\%A7\%C3\%A3o.pdf. Acesso em 30 agosto de 20.

[9] REVISTA, Gestão. Revista/gestão\%20educacional [12143].pdf Pró-funcionário Curso Técnico de Formação para os Funcionários da Educação. Acesso em: novembro 2019.

[10] RIBEIRO, Maria Edilene da Silva. Revista/MariaEdilenedaSilvaRibeiro_GT7[12144].pdf GESTÃO EDUCACIONAL: MODELOS E PRÁTICAS (UFPA) mariaedilene@ufpa.br Vera Lúcia Jacob Chaves (UFPA) veraluciajacob@gmail.com Acesso em: novembro 2019.

[11] SANTOS, PRADO (2018). ISSN 2237-9460 Revista Êxitos, Santarém/PA, Vol. 8, No 1, p. 59 - 86, JAN/ABR 2018. 59.pdf. ENTRE A ELEIÇÃO E A INDICAÇÃO POLÍTICA: as relações de poder no cotidiano do gestor escolar. Por: Isabela Macena dos Santos, Edna Cristina do Prado. Acesso em: 31 de agosto de 2020.

[12] ZERBINI, Paula Rodrigues 2012. A Interferência Política na Gestão Escolar. https://core.ac.uk/download/pdf/196870470 PDF. Aspectos do Ambiente Organizacional, tendo em vista os desafios da legislação ... Acesso em: 04 de setembro de 20. 


\section{Capítulo 3}

\section{Custo da educação pública federal no Brasil: As metodologias utilizadas pelo TCU e pelo MEC}

\section{Evandro Cherubini Rolin}

Resumo: Com o aumento das matrículas nas Instituições de Ensino Superior (IES) tornase necessário pensar no desafio de continuar crescendo apesar das limitações impostas aos gastos públicos, sendo necessário pensar em formas de tornar o gasto público mais transparente ao cidadão e aos órgãos de controle. Dessa forma, esse trabalho tem o objetivo de comparar o cálculo do custo-aluno na educação pública federal no Brasil a partir de 2009, analisando os resultados referentes ao ensino superior, obtidos por meio das metodologias utilizadas pelo Tribunal de Contas da União (TCU) e pelo Ministério da Educação (MEC). Os resultados mostram que tem ocorrido redução nos valores percentuais entre os métodos de apuração no período de 2009 a 2014, variando de $66,87 \%$ para $15,42 \%$.

Palavras-chave: Custo-aluno. Educação Superior. Metodologias. Indicadores. 


\section{INTRODUÇÃO}

O cálculo do custo-aluno é um fator importante para a apuração dos custos nas IES, entretanto, os resultados dos métodos de apuração podem divergir como ocorre com as metodologias utilizadas pelo TCU e pelo MEC.

O tema custo-aluno é tratado na Lei no 9.394/1996, que associa o custo do aluno a um padrão mínimo de qualidade e ressalta que o custo deve considerar os insumos e as diversas modalidades de ensino (BRASIL, 1996). Da mesma forma, a Lei no $13.005 / 2014$ estabelece o conceito do custo-aluno qualidade (CAQ) para a educação básica e pública (BRASIL, 2014).

O tema passou a ser objeto de estudo nos trabalhos de Levy, Campino e Nunes (1970), Castro (1973), Paro (1982) e Verhine (1998), sendo considerados trabalhos pioneiros no Brasil.

Com base nas discussões acerca do custo-aluno, o TCU, através da Decisão Plenária no 408/2002, determinou que as IES da administração federal passassem a incluir a partir de 2002, em seus relatórios de gestão anual, um conjunto de indicadores para a avaliação do desempenho das IES, entre eles o valor do custo por aluno (BRASIL, 2004).

Dessa forma, o custo-aluno mostra-se de suma importância para a área educacional, sendo importante para o enfrentamento dos desafios da educação no contexto atual, uma vez que considera a redução dos limites orçamentários e financeiros que afetam toda a educação pública no Brasil. Portanto, faz-se necessário pensar em formas de tornar o gasto público mais transparente ao cidadão e aos órgãos de controle.

Com base nesse contexto, o objetivo desse trabalho é comparar o custo-aluno na educação pública federal, analisando os resultados referentes ao ensino superior, obtidos por meio das metodologias utilizadas pelo TCU e pelo MEC.

Trata-se de metodologia quantitativa com fonte de dados secundários, sendo os mesmos de origem documental e analisados com base na estatística descritiva.

Na sequência serão analisados os métodos utilizados pelo TCU e pelo MEC, comprando os resultados dos valores do custo-aluno das IES.

\section{METODOLOGIAS UTILIZADAS PELO TCU E PELO MEC}

Além da legislação citada na introdução, a base legal sobre custos baseia-se nas normativas da contabilidade de custos, como a Resolução CFC $n^{\circ} 1.437 / 2013$ e a Resolução CFC $n^{\circ} 1.366 / 2011$, que estabelece a conceituação, o objeto, os objetivos e as regras básicas para mensuração e evidenciação dos custos no setor público (BRASIL, 2011).

Com base nessas normativas, o TCU propôs a utilização de indicadores de gestão que certifiquem a eficácia e a eficiência da gestão administrativa das IES em relação às atividades e projetos desenvolvidos. Estes indicadores foram definidos a partir de auditorias realizadas nas próprias IES (SILVA et al., 2003).

De acordo com o TCU, o que se pretende com estes indicadores é a construção de uma série histórica de dados para acompanhar a evolução de aspectos relevantes do desempenho de todas as IES. As informações gerenciais extraídas desse acompanhamento deverão servir de subsídio para selecionar áreas a serem estudadas com maior profundidade pelos órgãos responsáveis pelos controles interno e externo das Instituições.

Os dados fornecidos pelo TCU acompanham a metodologia de distribuição dos dados no SIMEC, sendo divididos por um grupo que apura os dados brutos e por outro onde são calculados os indicadores relacionados aos diversos componentes apurados no primeiro grupo.

Para ter acesso aos dados do Simec é necessário autorização da autoridade superior da IES, dessa forma, os dados dos indicadores do TCU utilizados nesse trabalho foram obtidos por meio da página da Universidade Federal de Rondônia, a qual disponibilizou os relatórios dos indicadores do TCU do período de 2006 a 2017 (BRASIL, 2016). 
Um dos indicadores do TCU é o Custo corrente / aluno equivalente em tempo integral, sendo o mesmo um indicador de eficiência que mede o custo anual por aluno matriculado na IES. Entende-se por aluno equivalente a soma dos Alunos Equivalentes da graduação mais a soma dos alunos da Pós Graduação em tempo integral e a soma dos alunos de residência médica em tempo integral (BRASIL, 2004).

A partir dos relatórios anuais dos indicadores disponíveis pelo TCU, obtiveram-se os valores do custo corrente por aluno equivalente em tempo integral das 63 IES públicas federais no Brasil para o período de 2009 a 2017, conforme apresentado no Quadro 1.

Quadro 1 - Média do indicador custo corrente por aluno equivalente em tempo integral das IES públicas federais do Brasil - TCU (2009-2017).

\begin{tabular}{|c|c|c|}
\hline \multirow{2}{*}{ Ano } & № IES & $\begin{array}{c}\text { Média do Custo corrente / aluno equivalente tempo integral (excluindo as } \\
\text { despesas do(s) HU(s)) }\end{array}$ \\
\hline 2009 & 57 & $\mathrm{R} \$ 11.846,98$ \\
\hline 2010 & 57 & $\mathrm{R} \$ 13.597,63$ \\
\hline 2011 & 59 & $\mathrm{R} \$ 14.871,60$ \\
\hline 2012 & 59 & $\mathrm{R} \$ 15.290,59$ \\
\hline 2013 & 60 & $\mathrm{R} \$ 17.893,95$ \\
\hline 2014 & 64 & $\mathrm{RS} 18.952,05$ \\
\hline 2015 & 64 & $\mathrm{R} \$ 19.073,75$ \\
\hline 2016 & 63 & $\mathrm{R} \$ 23.385,88$ \\
\hline 2017 & 63 & $\mathrm{R} \$ 22.025,79$ \\
\hline
\end{tabular}

Fonte: Elaborado pelo autor a partir nos indicadores TCU (2009-2017), com base na Decisão Plenária n.o 408 de 2002.

Como para o período de 2006 a 2008 não são apresentados todos os dados, os resultados desses anos não foram incluídos na análise. Dessa forma, os valores variam de R\$11.846,98 em 2009 (57 IES) para $\mathrm{R} \$ 22.025,79$ em 2017 (63 IES). Observa-se uma variação de 85,92\% no período entre os valores utilizados na metodologia do TCU.

Por sua vez, a metodologia utilizada pelo MEC considerou os seguintes grupos de natureza de despesa: pessoal ativo e encargos sociais; outras despesas correntes; investimentos e inversões financeiras. Não se incluem nestas informações as seguintes despesas: aposentadorias e reformas, pensões, recursos para bolsa de estudo e financiamento estudantil, despesas com juros e encargos da dívida e amortizações da dívida da área educacional e a modalidade de aplicação: transferências correntes e de capital ao setor privado (BRASIL, 2002, 2015).

A educação superior corresponde aos cursos superiores em tecnologia, demais cursos de graduação (presencial e a distância) e cursos de pós-graduação stricto sensu, sendo os dados coletados do Sistema Integrado de Administração Financeira - Siafi/STN - para todos os anos (BRASIL, 2002, 2015).

Dessa forma, a Tabela 1 apresenta uma estimativa do investimento público direto em educação por estudante, divulgada pelo INEP/MEC, para o período de 2000 a 2014 (BRASIL, 2015). 
Tabela 1- Estimativa do investimento público direto em educação por estudante, com valores atualizados para 2014 pelo Índice Nacional de Preços ao Consumidor Amplo (IPCA); e a proporção do investimento público por estudante da educação superior sobre o investimento público por estudante da educação básica, por nível de ensino - Brasil 2000-2014.

\begin{tabular}{|c|c|c|c|c|c|c|c|c|}
\hline \multirow{4}{*}{ Ano } & \multicolumn{8}{|c|}{$\begin{array}{l}\text { Investimento Público Direto por Estudante } \\
\qquad \mathrm{R} \$ 1,00\end{array}$} \\
\hline & \multirow{3}{*}{$\mid \begin{array}{c}\text { Todos os Niveis } \\
\text { de Ensino }\end{array}$} & \multicolumn{6}{|c|}{ Niveis de Ensino } & \multirow{3}{*}{$\begin{array}{c}\text { Proporção da } \\
\text { Educação Superior } \\
\text { sobre a Educação } \\
\text { Básica (Estudante) }\end{array}$} \\
\hline & & \multirow[b]{2}{*}{$\begin{array}{l}\text { Educação } \\
\text { Básica }\end{array}$} & \multirow[b]{2}{*}{$\begin{array}{l}\text { Educação } \\
\text { Infantil }\end{array}$} & \multicolumn{2}{|c|}{ Ensino Fundamental } & \multirow[b]{2}{*}{ Ensino Médio } & \multirow[b]{2}{*}{$\begin{array}{l}\text { Educação } \\
\text { Superior }\end{array}$} & \\
\hline & & & & $\begin{array}{c}\text { De } 1^{2} \text { a } 4^{2} \\
\text { Séries ou Anos } \\
\text { Iniciais }\end{array}$ & \begin{tabular}{|c|} 
De $5^{2}$ a $8^{2}$ \\
Séries ou Anos \\
Finais
\end{tabular} & & & \\
\hline 2000 & 2.338 & 1.946 & 2.455 & 1.866 & 1.954 & 1.878 & 21.341 & 11,0 \\
\hline 2001 & 2.416 & 2.014 & 2.191 & 1.846 & 2.129 & 2.112 & 21.089 & 10,5 \\
\hline 2002 & 2.397 & 1.986 & 2.051 & 2.174 & 2.051 & 1.423 & 19.531 & 9,8 \\
\hline 2003 & 2.355 & 1.978 & 2.338 & 2.088 & 1.977 & 1.578 & 17.067 & 8,6 \\
\hline 2004 & 2.497 & 2.135 & 2.353 & 2.385 & 2.205 & 1.441 & 16.157 & 7,6 \\
\hline 2005 & 2.660 & 2.254 & 2.188 & 2.556 & 2.378 & 1.528 & 17.409 & 7,7 \\
\hline 2006 & 3.164 & 2.749 & 2.391 & 2.863 & 3.125 & 2.123 & 18.023 & 6,6 \\
\hline 2007 & 3.696 & 3.218 & 2.899 & 3.365 & 3.552 & 2.576 & 19.044 & 5,9 \\
\hline 2008 & 4.183 & 3.695 & 3.097 & 3.877 & 4.134 & 2.980 & 17.602 & 4,8 \\
\hline 2009 & 4.601 & 4.046 & 3.101 & 4.374 & 4.567 & 3.142 & 19.769 & 4,9 \\
\hline 2010 & 5.294 & 4.654 & 3.808 & 5.000 & 5.010 & 3.958 & 21.013 & 4,5 \\
\hline 2011 & 5.791 & 5.045 & 4.507 & 5.175 & 5.189 & 4.906 & 22.389 & 4,4 \\
\hline 2012 & 6.168 & 5.472 & 5.313 & 5.572 & 5.353 & 5.582 & 20.335 & 3,7 \\
\hline 2013 & 6.601 & 5.847 & 5.783 & 5.873 & 5.809 & 5.902 & 22.753 & 3,9 \\
\hline 2014 & 6.669 & 5.935 & 5.878 & 5.911 & 5.927 & 6.021 & 21.875 & 3,7 \\
\hline
\end{tabular}

.Fonte: Inep/MEC - Tabela elaborada pela Deed/Inep.

O INEP/MEC fornece uma estimativa do investimento público direto em educação por estudante para o período de 2000 a 2014, separada por nível de ensino. Para a educação superior observa-se que os valores variam de $\mathrm{R} \$ 21.341,00$ em 2000 para $\mathrm{R} \$ 21.875,00$ em 2014, apresentando, dessa forma, uma variação de apenas 2,5\% no período entre os valores utilizados na metodologia do MEC.

Sendo assim, comparando os dados obtidos por meio das metodologias utilizadas pelo TCU e pelo MEC, obtém-se a Tabela 2 que apresenta as diferenças dos valores do custo-aluno ano no ensino superior, considerando somente os anos que possuem dados divulgados pelos dois órgãos.

Tabela 2 - Comparação dos valores do custo-aluno ano do ensino superior entre as metodologias utilizadas pelo TCU e pelo MEC, para o período de 2009 a 2014.

\begin{tabular}{|c|c|c|c|}
\hline Ano & Custo-aluno TCU & Custo-aluno MEC & Diferença (\%) \\
\hline 2009 & $\mathrm{R} \$ 11.846,98$ & $\mathrm{R} \$ 19.769,00$ & 66,87 \\
\hline 2010 & $\mathrm{R} \$ 13.597,63$ & $\mathrm{R} \$ 21.013,00$ & 54,53 \\
\hline 2011 & $\mathrm{R} \$ 14.871,60$ & $\mathrm{R} \$ 22.389,00$ & 50,55 \\
\hline 2012 & $\mathrm{R} \$ 15.290,59$ & $\mathrm{R} \$ 20.335,00$ & 32,99 \\
\hline 2013 & $\mathrm{R} \$ 17.893,95$ & $\mathrm{R} \$ 22.753,00$ & 27,15 \\
\hline 2014 & $\mathrm{RS} 18.952,05$ & $\mathrm{R} \$ 21.875,00$ & 15,42 \\
\hline
\end{tabular}

Fonte: Elaborado pelo autor a partir dos dados divulgados pelo Inep/MEC e TCU.

Ao compararmos os valores do custo-aluno por ano entre as duas metodologias, considerando o período de 2009 a 2014, uma vez que somente nesse período há dados divulgados pelos dois órgãos, chega-se a uma redução dos resultados entre os métodos anualmente, variando de 66,87\% em 2009 para 15,42\% em 2014. Essa redução pode representar que houve uma aproximação das metodologias utilizadas para o cálculo do indicador em cada órgão, como na equalização do conceito aluno-equivalente, em função das diferenças para implantação entre os cursos, assim como da apuração dos custos correntes. 


\section{CONSIDERAÇÕES FINAIS}

O objetivo desse trabalho era comparar o custo-aluno anual do ensino superior na educação pública federal no Brasil, analisando os resultados obtidos por meio das metodologias utilizadas pelo TCU e pelo MEC.

Notou-se que o cálculo do custo-aluno é um fator importante para a apuração dos custos nas IES, entretanto, dependendo da metodologia empregada na apuração, os resultados podem apresentar diferenças.

Essas diferenças podem ocorrer no momento da apuração dos chamados custos corrente e permanente, assim como na ponderação dos cursos para o levantamento do aluno-equivalente. Como visto, há uma constante redução das diferenças apuradas por meio dos métodos do TCU e do MEC até o ano de 2014, sendo esse o último ano divulgado pelo MEC. Verificamos que houve uma redução na diferença de $66,87 \%$ em 2009 para $15,42 \%$ em 2014.

Ressalta-se a variação de 85,92\% no período de 2006 a 2008 entre os valores utilizados na metodologia do TCU, representando que houve alterações significativas na metodologia de apuração do custo-aluno utilizada pelo órgão. Já a metodologia utilizada pelo MEC, com variação de apenas 2,5\% no período de 2009 a 2014, representa que não houve alterações significativas no método.

Entretanto, para uma avaliação mais precisa é necessário aprofundar os estudos tratados na contabilidade de custos, analisando se os dados apurados pelo TCU e pelo MEC consideraram, por exemplo, os custos diretos e indiretos, assim como os custos fixos e variáveis.

\section{REFERÊNCIAS}

[1] BRASIL. Lei ${ }^{\circ}$ 9.394, de 20 de dezembro de 1996. Estabelece as diretrizes e bases da educação nacional. Brasília, DF. Disponível em: <https://www.planalto.gov.br/ccivil_03/Leis/L9394.htm>. Acesso em: 6 jan. 2021.

[2] _ _ Dados e Indicadores das Instituições Federais de Ensino Superior - IFES em 2000. Secretaria de Educação Superior. Brasília: MEC/SESu, 2002. 224 p. Disponível em: < http://portal.mec.gov.br/sesu/arquivos/pdf/indIFES2000.pdf>. Acesso em: 6 jan. 2021.

[3] _ . Tribunal de Contas da União. Orientação para o cálculo dos indicadores de gestão. Decisão TCU $n$. 408/2002 - Plenário. Rev. mar. 2004. Disponível em: < http://portal.mec.gov.br/sesu/arquivos/pdf/indicadores.pdf>. Acesso em: 6 jan. 2021.

[4] . Resolução CFC n. 1.366 de 25 de novembro de 2011. Aprova a NBC T 16.11 - Sistema de Informação de Custos do Setor Público. Brasília/DF. Disponível em: < http://www.normaslegais.com.br/legislacao/resolucao-cfc1366-2011.htm>. Acesso em: 6 jan. 2021.

[5] L. Lei $n^{\circ}$ 13.005, de 25 de julho de 2014. Aprova o Plano Nacional de Educação - PNE e dá outras providências. Disponível em:<http://www.planalto.gov.br/ccivil_03/_Ato2011-2014/2014/Lei/L13005.htm>. Acesso em: 6 jan. 2021.

[6] _. Indicadores Financeiros Educacionais. INEP/MEC. Brasília, DF, 2015. Disponível em: <http://portal.inep.gov.br/indicadores-financeiros-educacionais>. Acesso em: 6 jan. 2021. __. Relatório dos Indicadores do TCU - SIMEC. Coordenadoria de Informação de Desempenho. Fundação Universidade Federal de Rondônia. Porto Velho: 2016. Disponível em: < http://www.cid.unir.br/pagina/exibir/5508>. Acesso em: 6 jan. 2021.

[7] CASTRO, C. M. Investimento em educação no Brasil: um estudo sócio-econômico de duas comunidades industriais. Rio de Janeiro: IPEA / INPES, 1973.

[8] LEVY, S.; CAMPINO, A. C.; NUNES, E. M. Análise econômica do sistema educacional de São Paulo. Instituto de Pesquisa Econômicas / Faculdade de Economia e Administração da Universidade de São Paulo. 1970.

[9] PARO, V. H. O custo do ensino público no estado de São Paulo: estudo de custo-aluno na rede estadual de primeiro e segundo graus. Caderno de Pesquisa, São Paulo, n.43, p. 3-29, 1982.

[10] SILVA, et al. Desenvolvimento e aplicação de uma metodologia para cálculo do custo-aluno de instituições públicas de ensino superior: um estudo de caso. In: X Congresso Brasileiro de Custos. Guarapari, ES, 2003.

[11] VERHINE, R. E. Determinação de custos educacionais: Uma análise panorâmica do estado da arte. Revista Educação, PUC/RS, 1998, p. 107-122. 


\section{Capítulo 4}

\section{A racionalidade empresarial na educação de Maceió}

\section{Adelson Gomes da Silva}

\section{Elione Maria Nogueira Diógenes}

Resumo: Este artigo apresenta parte dos resultados encontrados na Pesquisa de Doutorado acerca da política educacional de Maceió (2010/2019), desenvolvida no PPGE/UFAL. 0 estudo teve como objetivo analisar a atuação do PNUD na elaboração e execução da política educacional de Maceió, e a sua contribuição na implementação do gerencialismo como modelo de gestão da educação, na rede municipal de educação da capital alagoana. Para tal, foi utilizado o método da análise documental e se fundamentou na teórica crítica do currículo, a partir das produções teóricas de Apple (2011), Ball (2011), Moreira (2008), Libâneo (2011) e Silva (1997) que nos revelaram um avanço da racionalidade empresarial/gerencial na gestão da educação de Maceió, onde o ensino é apresentado como produto mercantil, que deve ser padronizado para facilitar o controle de sua qualidade; onde os alunos são considerados como clientes -- meros consumidores --; e, nesse contexto, os professores são tidos como proletários, comprometidos com metas de produtividade que têm como característica a instrumentalização do processo pedagógico, em detrimento de uma formação intelectual crítica.

Palavras-chave: Política educacional. Gerencialismo escolar. Padronização do currículo. Monitoramento. Controle. 


\section{INTRODUÇÃO}

Por meio deste artigo, apresentamos os resultados parciais da pesquisa de Doutorado que analisa a política educacional de Maceió (2010/2019), desenvolvida junto ao Programa de Pós-graduação em Educação do Centro de Educação da Universidade Federal de Alagoas. A problemática central da pesquisa é o processo de implementação da racionalização empresarial na educação de Maceió - no formato de padronização do ensino e da aprendizagem --, implementado na Rede Municipal de Educação, e os seus efeitos na gestão escolar, como também, no trabalho pedagógico dos professores, que é caracterizado pelo mesmo formato.

O objetivo deste artigo é analisar a atuação do PNUD na elaboração e execução da política educacional de Maceió e sua contribuição na implementação do gerencialismo, como modelo de gestão da educação, na rede municipal de educação da capital alagoana.

A implementação do gerencialismo na gestão pública faz parte de um projeto neoliberal para a educação pública levado a cabo, pelos organismos multilaterais, como política pública, nos países em desenvolvimento. Essa política tem como finalidade principal o empresarialismo da gestão pública, cujas características são a padronização dos processos por meio de cumprimento de metas preestabelecidas e o monitoramento e mensuração dos resultados, além da necessidade do controle do trabalho docente.

Para orientar a análise no recorte que fizemos neste artigo, foi adotado o método da análise documental e os referenciais da teórica crítica do campo da educação e, especificamente, do campo de estudo sobre o currículo escolar.

0 artigo foi organizado em duas partes, sendo que a primeira parte consiste em uma breve apresentação do processo de elaboração e implementação da política educacional de Maceió a partir do recorte temporal (2010/2019), que marca a atuação do PNUD na secretária municipal de educação de Maceió e, na segunda parte, foi realizada uma reflexão sobre o avanço da racionalização empresarial na educação de Maceió, por meio do gerencialismo, como forma de gestão educacional.

\section{A ATUAÇÃO DO PNUD NA EDUCAÇÃO DE MACEIÓ}

Para a realização deste trabalho, foi efetivado um recorte temporal de análise da política educacional de Maceió que teve como marco a atuação do PNUD, na capital alagoana. Inicialmente foi verificado, nos principais documentos da Secretaria Municipal de Educação de Maceió (SEMED), que o Programa das Nações Unidas para o Desenvolvimento (PNUD- BRASIL) teve início, na SEMED, no ano de 2014. Assim, conforme documento SEMED, "O Projeto SEMED-PNUD teve início em 2014 por meio de cooperação técnica, que contou com o apoio do Ministério da Educação (...) e que o encerramento do Projeto SEMED-PNUD ocorreu em 2019" (PNUD, 2019 - apresentação). No entanto, há vários relatórios produzidos pela própria SEMED que dão conta da presença do PNUD, na SEMED, desde o início no ano de 2010.

No período entre 2010 e 2013, observamos que o PNUD centrou seus esforços na elaboração de relatóriosdiagnósticos sobre a situação educacional da capital alagoana e em relatórios técnicos que subsidiaram as diretrizes de ensino que seriam publicadas nos anos posteriores. Parte desses documentos fundamentou o "Projeto Cidade Educar (2011)" que não chegou a ser lançado oficialmente, sendo reformulado e transformado no "Projeto Viva Escola (2014)" que reúne as principais ações fruto da atuação do PNUD na educação de Maceió, dentre elas, a publicação das diretrizes para o ensino das diferentes modalidades e etapas da educação, além do guia de orientação para a gestão escolar.

O “Projeto Cidade Educar (2011)" tinha como objetivo a estruturação da Secretaria Municipal de Educação, tanto na sua dimensão pedagógica, como na administrativa. A seguir, será apresentado um resumo dos quatro eixos de atuação a que se propunha o projeto em referência.

Dimensão I - Gestão Educacional, composta por 5(cinco) ações: Ação 1 - definição da Estrutura Organizacional da Administração Central da SEMED; Ação 2 - definição da Estrutura Organizacional das Unidades Escolares; Ação 3 - planejamento da capacitação do pessoal da Unidade Central e das Unidades Escolares na Operacionalização das novas Estruturas Organizacionais; Ação 4 - Estabelecimento de Padrões de Lotação de Pessoal nas Unidades Escolares; Ação 5 - Elaboração do Programa de Comunicação da SEMED - Controle Social e Endomarketing.

Dimensão II - Formação Continuada de professores e de profissionais de serviços e apoio escolar, composta por 2 (duas) ações: Ação 1 - Programa de Formação Continuada de Professores e Equipe Gestora da Escola (Coordenadores, Diretores e Conselho Escolar); Ação 2 - Formação Continuada de Profissionais de Serviços e de Apoio, escolares. 
Dimensão III - Práticas Pedagógicas e Avaliação, composta por 5 (cinco) ações: Ação 1 - Definição e Implementação das Diretrizes Curriculares para a Educação Infantil e para o Ensino Fundamental nas diferentes Modalidades e Diversidades; Ação 2 - Programa de Alfabetização da Rede Municipal de Ensino de Maceió; Ação 3 - Implementação de Programa de Correção de Fluxo; Ação 4 - Avaliação na Rede Municipal de Ensino de Maceió; Ação 5 - Uso Didático-Pedagógico das Tecnologias da Informação e Comunicação.

Dimensão IV - Infraestrutura Física, composta por 5(cinco) ações: Ação 1 - TIC - Implantação e Capacitação do Sistema de Gerenciamento da Rede Escolar de Gestão das Escolas da SEMED; Ação 2 - Suporte de Tecnologia de Informação e Comunicação para a SEMED/MACIEÓ; Ação 3 - Mapeamento para a Estruturação da Rede Pública Municipal de Maceió; Ação 4 - Aplicação do Levantamento da Situação Escolar - LSE na Rede Municipal de Maceió; Ação 5 - Elaboração de Padrões Básicos para o Mobiliário Escolar da Rede Pública Municipal de Maceió.

As análises desses documentos foram evidenciando o direcionamento para a implantação do gerencialismo como forma de gestão da educação de Maceió onde as escolas deveriam ser administradas ou geridas nos moldes das empresas privadas. Percebeu-se que a SEMED passou a adotar os princípios da gestão privada empresarial como modelo para a gestão de sua política educacional, assumindo, inclusive, em suas práticas administrativas, não só a lógica de mercado, mas também a criação e incorporação, em sua discursividade, termos da administração empresarial, na gestão das suas unidades escolares.

As unidades escolares, as coordenações de departamentos de ensino e os setores educacionais da Secretaria Municipal de Educação de Maceió foram orientadas pelo PNUD a elaborarem seus planejamentos estratégicos assumido o modelo e a lógica de Unidades Gerenciais (UGs), e, como tais, passaram a adotar uma linguagem própria do setor empresarial, em seus discursos e práticas, incorporando termos, como padrões, monitoramento, controle de processos, insumos, fornecedores, produtos, estoques e clientes, dentre outros.

Na elaboração do planejamento estratégico da educação de Maceió (2013), o PNUD orientou que tomasse como referencial a metodologia PDCA (Planejamento, Execução, Checagem, Ação), que é largamente utilizada por corporações que desejam melhorar seu nível de gestão, através do controle de processos, padronizando informações e minimizando as chances de erros na tomada de decisões, ou seja, empresas que logram maximizar seus lucros por meio de eficiência da gestão dos recursos, tanto humano como material.

Esses procedimentos aplicados ao planejamento educacional demonstram bem o caráter empresarial que é dado às unidades de ensino da Secretária Municipal de Maceió. Na aplicação do ciclo do PDCA, as palavras de ordem são: gerenciamento, processo, controle e monitoramento. Esses termos são incorporados pela SEMED e ressignificados, no contexto da gestão educacional e escolar.

O período entre 2014 e 2019 marca o segundo momento da atuação do PNUD na educação de Maceió e é considerado como etapa de implementação da atual política educacional da capital alagoana, na qual se efetivou a elaboração e implementação de diretrizes de ensino para as etapas e modalidades de ensino, e orientações para a gestão das unidades escolares. Nesse período, também ocorreu a substituição do "Projeto Cidade Educar" pelo "Projeto Viva Escola", cujo foco passou a se concentrar nos processos de ensino e gestão.

Nessa nova etapa, uma das primeiras ações da SEMED, conjuntamente com o PNUD, foi a elaboração das Diretrizes Curriculares para o Ensino Fundamental que aponta como prioridade a criação de uma política de padrões básicos entendida como a definição de conteúdos mínimos a serem ensinados nas escolas. De acordo com a SEMED (2014, p. 23), a implementação dessa política "requer garantias institucionais quanto ao acompanhamento, apoio, monitoramento e avaliação dos resultados junto às escolas", daí a centralidade no monitoramento do trabalho pedagógico e controle dos resultados do ensino.

Outro foco da política de padrões de aprendizagem passou a ser as parcerias com instituições privados na execução da política educacional, para o PNUD (2019, p. 52) "parceiros são parte do capital político e social de uma boa gestão pública", o que abre caminho para implementação do gerencialismo empresarial na gestão da educação de Maceió.

Como forma de exemplificar a centralidade nas parcerias com setores empresárias na gestão educacional de Maceió, citamos a atuação do Instituto Ayrton Senna, que implementou os principais programas educacionais em Maceió em parceria com a SEMED, tais como, o Programa "Se Liga" e "Acelera Brasil", ambos voltados para a correção de fluxo. 
Assim, o monitoramento passou a ser um ponto central da implementação da política educacional de Maceió, tanto nas ações executadas pela própria Secretaria, como nas executadas por instituições parceiras.

\section{GERENCIALISMO NA EDUCAÇ̃̃O DE MACEIÓ}

0 termo gerencialismo é utilizado para designar o modelo de gestão baseado na racionalidade empresarial, que ganha força na área da educação com a ascensão das ideias neoliberais nas políticas educacionais, a partir das reformas do início dos anos 90, no contexto de restruturação produtiva. Para Libâneo (2011, p. 154), "após as reformas educacionais de meados dos anos 90, existe na área educacional a racionalidade financeira, com preocupações sobre custo-benefício, eficácia na execução e excelência do produto, preocupações provenientes do ambiente empresarial". Na educação de Maceió, o gerencialismo está velado no discurso da eficiência como princípio da gestão educacional, conforme expresso nas diretrizes curriculares para o ensino fundamental: " a gestão escolar deve discutir os conceitos de eficiência, eficácia e efetividade (...) esta nova etapa da gestão escolar da Rede Municipal de Maceió é precursora de um cenário promissor de maior eficiência, eficácia e efetividade" (SEMED, 2014, pp. 23, 26). 0 discurso da eficiência na educação pública ocorre dentro de uma lógica de mercado, em que o ensino é tratado como um produto a ser entregue para os clientes, seguindo determinados padrões de qualidade.

No contexto do gerencialismo empresarial, é questionada a capacidade do setor público na gestão da eficiência de resultados por receber influências de fatores burocráticos e tipos de gestão pública. Assim, os adeptos da gestão de resultados na educação defendem que setor público assuma a lógica da racionalidade empresarial para tornar-se eficiente, alimentando o discurso sobre a necessidade de modernização na gestão pública. Na educação, por modernização da gestão pública entende-se, como indicador de eficiência, a implementação da racionalidade empresarial. De acordo com Libâneo (2011, p. 55), "o discurso de modernização educativa, da diversificação, da flexibilidade, da competitividade, da produtividade, da eficiência e da qualidade dos sistemas educativos, da escola e do ensino, na ótica das reformas neoliberais de adequação às demandas e exigências do mercado". Assim, os discursos e a defesa pela modernização da educação para a eficiência são justificados pelos argumentos de que o setor público, com suas travas burocráticas, tem dificuldade em desenvolver uma gestão baseada nos princípios do mercado.

Portanto, para o gerencialismo educacional ser eficiente é necessário que a escola forme pessoas mais competitivas/produtivas, capazes de atender às demandas do mercado, que necessita produzir mais, gastando menos, e no menor tempo possível (eficiência, eficácia e efetividade). Tal estratégia justifica a defesa da centralidade dos currículos escolares, no ensino de competências e habilidades.

A racionalização empresarial implementa a educação na busca de uma suposta eficiência que transforma a educação em mercadoria fazendo parte da investida neoliberal de um projeto global do capital, que tem como emissor os organismos multilaterais. De acordo com Silva (1997, p. 15),

[...] a celebração da suposta eficiência e produtividade da iniciativa privada em oposição à ineficiência e ao desperdício dos serviços públicos; a redefinição da cidadania pela qual o agente político se transforma em elementos centrais importantes do projeto neoliberal global. É nesse projeto global que se insere a redefinição da educação em termos de mercado.

O discurso da eficiência na educação pública é usado estrategicamente pelo Capital, por intermédio de seus organismos internacionais, para a difusão de seu projeto neoliberal de fazer da educação a transmissora dos interesses do mercado produtivo. Para isso, busca implementar, na educação pública, a racionalidade empresarial. Conforme Libâneo (2011, p. 149),

Na educação básica, orientada até mesmo por organismos internacionais como o Banco Mundial, o Estado deve atender o ensino público, uma vez que esse nível de educação é considerado imprescindível na organização do trabalho. Tal atendimento, no entanto, vem sendo conduzido por parâmetros de gestão da iniciativa privada e no mercado, tais como diversificação, competitividade, seletividade, eficiência e qualidade. Essa orientação aponta, mais uma vez, o beneficiamento das forças privatistas na educação.

A implementação da racionalidade empresarial na gestão da educação pública é vista como uma estratégia ou uma forma para privatizar educação, e não se trata de uma configuração voltada para a privatização da educação, porém, não tem a finalidade de privatizar a educação e de deixar a cargo do setor privado o controle administrativo de todas as instituições públicas, mas, de implementar, em todas as instituições 
públicas de ensino, o modelo de gestão do setor privado, especialmente, o gerencialismo empresarial. Silva (1997, p. 23), nos alerta que não se trata necessariamente de privatizar, "mas de fazer a educação pública funcionar à semelhança do mercado". Portanto, o discurso da eficiência na gestão educacional e, especificamente, na gestão das instituições de ensino, não passa de uma iniciativa do capital para imprimir nas escolas públicas a lógica do mercado, tornando-as empresas mercantis.

Assim, o gerenciamento representa um modelo de gestão característico do setor privado, dominante na administração de empresas capitalistas, que têm como finalidade última, a acumulação de capital, que ocorre, principalmente, por meio da exploração do trabalho. A incorporação desse termo no campo da educação não é algo novo, ele surge em um contexto de avanço da ideologia neoliberal na educação, em que o setor público passa a ser considerado e regido a partir dos princípios da empresa privada.

Destacamos a análise de Ball (2011) que, ao analisar as transformações ocorridas nas políticas educacionais do Reino Unido no início do século XXI, destaca que houve transformações nos princípios da organização no setor público, que incorporou o discurso do "empreendedorismo" em uma nova forma de regulação do Estado, a partir dos ideários do neoliberalismo, em uma estratégia que, de acordo com Ball (2011, p. 24), "os pontos - chave da ligação entre a reestruturação e a reavaliação (ou redirecionamento ético) do setor público são os discursos de excelência, efetividade e qualidade, bem como a lógica e a cultura do novo gerencialismo". Todas essas características são percebidas na política educacional de Maceió.

Por meio da análise dos documentos oficiais da SEMED, percebemos um direcionamento para a implementação do gerencialismo na gestão educacional de Maceió. 0 "Planejamento das ações da Diretoria Geral de Ensino - DIGEN - 2013" orientava os diversos setores internos da SEMED -- diretorias, setores, coordenações e unidades ensino --, a assumir a identidade de Unidades Gerenciais, usando termos específicos, como fornecedores, insumos, missão da unidade gerencial, processos, no que se refere aos produtos e aos clientes, no planejamento da política educacional do município.

No referido documento, os termos da administração privada do setor empresarial são ressignificados no campo da administração educacional, em que os "fornecedores" são os órgãos que de certa forma financiam as atividades educacionais, ou "fornecem" as condições para o funcionamento das escolas e das sedes destas -- Secretaria de Educação, Ministério da Educação etc. --, seja do ponto de vista financeiro, seja do regulatório. Os insumos são considerados como os documentos oficiais produzidos, para serem "consumidos" pelas escolas, tais como: diretrizes de ensino, leis que regulamentam o funcionamento da educação e os recursos materiais para a manutenção do ensino. A missão da Unidade Gerencial é apresentada como a de "planejar, acompanhar e avaliar os resultados", ou seja, a função da Secretária de Educação do Município de Maceió é apresentada como a de controlar os processos pedagógicos, que, por sua vez, são apresentados como sendo os meios para a efetivação do ensino, tais como, o planejamento pedagógico, a formação continuada dos servidores, o acompanhamento e monitoramento das práticas pedagógicas e a avaliação dos resultados. Os produtos são apresentados como o resultado do trabalho pedagógico, que, em última instância, é o ensino que é "entregue" aos alunos, que são tratados como "clientes".

A racionalidade empresarial toma conta da educação tornando-a uma mercadoria como outra qualquer e, como tal, precisa seguir a lógica de mercado e ofertar produtos, de acordo com a demanda dos clientes. A respeito disso, Saltman (2011, p. 72) afirma que, nesse modelo de gestão educacional, "[...] os alunos tornamse, principalmente, consumidores da educação e clientes dos professores [...], os professores tornam-se executores de serviços, e não intelectuais críticos; o conhecimento se torna uma unidade discreta de um produto que pode ser trocado por empregos". Outra característica desse modelo de gestão é a tentativa da padronização dos "produtos", no caso, o produto educacional e a padronização dos serviços, do currículo e dos procedimentos de ensino. Neste sentido, Saltman (2011, pp. 71-72) apresenta as principais características do gerencialismo aplicado à gestão escolar: 
[...] o modelo empresarial aparece nas escolas no impulso à padronização e à rotina sob a forma de ênfases em padronização do currículo, padronização dos testes, instrução baseada em métodos, desabilitação dos professores, lições programadas e uma série de abordagens que visam a "execução eficiente" do ensino. [...] 0 modelo empresarial parte do princípio de que o ensino, como a produção nas fábricas, sempre pode ser acelerado e tornado mais eficiente por meio de modificações técnicas e de incentivos aos professores e aos alunos, tais como bônus em dinheiro.

Na política educacional de Maceió, essas evidências ficam claras na tentativa de padronização do currículo por meio da implementação da rotina da prática de ensino, passando pela implementação de "lições programadas" e a instrumentalização do trabalho pedagógico por meio da implementação de técnicas e incentivo aos professores e diretores, por meio de bônus.

Nesse sentido, foi tomada a política de correção fluxo escolar da SEMED que ocorre por meio dos Programas "Se Liga" e "Acelera Brasil", do Instituto Airton Senna, que estabelece uma rigorosa rotina de sala de aula, com lições programadas e acompanhadas de instrumentos de monitoramento do trabalho do professor, que trabalha principalmente revestido da figura do "professor mediador" que tem como principal função o monitoramento do trabalho dos professores, em sala de aula. As lições programadas desenvolvem a função de padronização do ensino, uma vez que, os livros de lições são usados em todas as partes do país, trabalhando os mesmos conteúdos, com a justificativa da defesa do direito da aprendizagem de "base comum".

Outra característica do modelo empresarial de gestão, na educação de Maceió, é a prática de incentivos por meio de bônus em dinheiro para as escolas, e de troféus para professores e alunos. No ano de 2019, a prefeitura de Maceió criou um prêmio em dinheiro para as escolas que alcançassem notas elevadas no IDEB, por meio da Lei Municipal 6.928 que estabelece prêmio para essas escolas:

A lei municipal estabelece às escolas que atingirem entre 5 e 5,9 pontos o prêmio de $\mathrm{R} \$ 8$ mil. As que ficarem entre 6 e 6,9, terão à disposição $R \$ 10$ mil. 0 prêmio de $\mathrm{R} \$ 15$ mil deverá ser destinado às escolas municipais que atingirem entre $7 \mathrm{e}$ 7,9 no Ideb e as que ficarem acima da média 8, até o patamar máximo de nota 10 , terão disponíveis $\mathrm{R} \$ 20$ mil.

O discurso de excelência classifica as escolas e, junto com elas, os gestores, os professores e todos os funcionários, competentes ou incompetentes, capazes ou incapazes, comprometidos ou descomprometidos. Assim como nas empresas, apresenta a figura do funcionário do mês, com premiação por ter alcançado a meta de produção, na educação de racionalidade empresarial; e tem o gestor do ano, aquele que conseguiu mobilizar sua equipe para alcançar as metas estabelecida pelo sistema.

A forma de premiação não fica só na quantia - dinheiro -- destinada às escolas que alcançaram a meta do IDEB. Há alguns anos, a SEMED criou o troféu IDEB que é entregue para a gestão da escola que alcança a meta preestabelecida pelo sistema. No troféu, estão escritas as palavras: COMPROMISO - DEDICAÇÃO RESULTADO. Assim, o resultado alcançado é fruto do compromisso e da dedicação dos gestores e da sua equipe de funcionários. E as escolas que não alcançaram o resultado esperado? Deduz-se que faltam aos seus gestores, e às suas equipes de funcionários, o compromisso e a dedicação, portanto, não serão premiados, nem com o prêmio em dinheiro, nem com o troféu para exibir na estante da escola. Todo esse discurso de excelência, eficiência e competência leva esses sujeitos a uma condição de autorresponsabilidade, pelo sucesso ou fracasso da política educacional.

Para Ball (2011) o discurso e a prática de incentivo a professores, por desempenho acabam por criar um perigoso ardil em que os professores e gestores estão caindo, que é a responsabilização pelo fracasso da educação e, também, por estes assumirem a disciplina de seu próprio desempenho. "Assim, por meio desses esquemas, professores são apanhados em uma armadilha, assumindo a responsabilidade por sua própria disciplinarização" (2011, p. 86). É o que temos notado na política educacional de Maceió quando analisamos seus documentos oficiais. 


\section{CONSIDERAÇÕES FINAIS}

As características do gerencialismo escolar estão veladas nos discursos produzidos pelo PNUD, e materializados, nos principais documentos que fundamentam a atual política educacional de Maceió, que buscam a implementação de padrões básicos de aprendizagem.

Diante da análise inicial dessa política, é possível perceber que o modelo gerencial toma conta do ideário de gestão da educação de Maceió, revelado no discurso da eficiência, eficácia e efetividade, características da administração empresarial, e ressignificadas na gestão pública, como sinônimo de qualidade educacional.

Com base nos autores que fundamentaram nosso trabalho é possível afirmar que esse modelo de gestão que é aplicado na educação pública tem como principal efeito a empresarialização do serviço educacional centrada na produtividade mercantil e no cumprimento de metas de produção, como bonificação e como forma de disciplinarização da força de trabalho. Dessa forma, a qualidade da educação é mensurada nos resultados quantitativos alcançados nas avaliações externas, de caráter nacional e internacional, estabelecendo uma espécie de competitividade entre os diferentes sistemas educacionais e entre os estabelecimentos de ensino, o que acaba, em última instância, por responsabilizar os professores e alunos pelo fracasso escolar e pela baixa qualidade da educação.

A análise nos revela, também, que a atuação dos organismos internacionais, nas políticas educacionais locais, tem contribuído para implementação do gerencialismo empresarial na gestão da educação e que a tentativa de padronização do ensino em Maceió tem como efeito a instrumentalização do trabalho pedagógico, em detrimento de uma formação intelectual crítica dos docentes.

\section{REFERENCIAS}

[1] APPLE, Michael W. Educação crítica: análise internacional/ Michael W. Apple, Wayne Au, Luís Armando Gandin; tradução: Vinícius Figueira; revisão técnica: Luís Armando Gandin. - Porto Alegre: Artmed, 2011.

[2] BALL, Stephen J. \& MAINARDES, Jeferson. Políticas educacionais: questões e dilemas. São Paulo: Cotrez, 2011.

[3] GOVERNO DO ESTADO DE ALAGOAS SECRETARIA DE ESTADO DA EDUCAÇÃO. OFICINAS DE LÍNGUA

PORTUGUESA GUIA DE ORIENTAÇÕES DIDÁTICO-PEDAGÓGICAS. Escola 10: Secretária Estatual de Educação, 2019. 5o Ano - Volume 1.

[4] MACEIÓ, Secretaria Municipal de Educação. Diretrizes da avaliação da/para aprendizagem da rede municipal de ensino de Maceió / [Secretaria Municipal de Educação]. - 2.ed. - Maceió: Editora Viva, 2017.

[5] ___. Secretaria Municipal de Educação. Guia prático de gestão escolar da rede municipal de ensino de Maceió: orientações para a formação continuada de gestores escolares / [Secretaria Municipal de Educação]. - Maceió: Editora Viva, 2016.

[6] MOREIRA, Antônio Flavio Barbosa \& SILVA, Tomaz Tadeu. Currículo, cultura e sociedade. 10 ed. - São Paulo, Cortez, 2008.

[7] PROGRAMA DAS NAÇõES UNIDAS PARA O DESENVOLVIMENTO - PNUD. RELATÓRIO ANUAL -2016:

caminhando para o futuro que queremos: PNUD Brasil, 2017.

[8] PROGRAMA DAS NAÇÕES UNIDAS PARA O DESENVOLVIMENTO - PNUD. Sonhando e construindo caminhos para a educação: a história da parceria entre a Secretaria Municipal de Educação de Maceió e o Programa das Nações Unidas para o Desenvolvimento. Brasília: PNUD, 2019.

[9] SALTMAN, Kenneth J. A “corporatização” e o controle das escolas. In: APPLE, Michael W. Educação crítica: análise internacional. - Porto Alegre: Artmed, 2011.

[10] SECRETARIA MUNICIPAL DE EDUCAÇÃO. Orientações curriculares para a educação infantil da rede municipal de Maceió / Secretaria Municipal de Educação. - Maceió: EDUFAL, 2015.

[11] SEMED/MACEIÓ. Relatório: DIMENSÃO: I - Gestão Educacional / AÇÃO 1 - Definição da estrutura organizacional da administração central da SEMED / Projeto De Cooperação Técnica MEC-PNUD-SEMED - Cidade Educar: Semed, 2011.

[12] SILVA, T. Tadeu. A "nova” direita e as transformações na pedagogia da política e na política da pedagogia. In: GENTILI, Pablo A. A \& SILVA, Tomaz Tadeu. Neoliberalismo, qualidade total e educação. - 5 ed. - Petrópolis: Vozes, 1997.

[13] TORRES, Santomé, Jurjo. A educação em tempos de neoliberalismo. Porto Alegre: Artmed, 2003. 


\section{Capítulo 5}

\section{Educação financeira nas escolas como instrumento de consciência social para adolescentes}

\section{Carollini Silva Thomaz Graciani \\ Leonardo Dias da Silva}

Resumo: A consciência financeira precisa estar presente nas escolas como proposta transdisciplinar. Principalmente aos alunos adolescentes que vivem em um consumo desenfreado e influenciado pela mídia. Em escolas particulares esses alunos gastam e não compreendem o valor das coisas, nem do trabalho. Em escolas públicas é preciso demonstrar que poupar pode trazer benefícios. 0 objetivo da pesquisa é levar para as escolas públicas da cidade de Resende-RJ uma proposta de projeto de extensão com a participação dos cursos de pedagogia e administração através de palestras, ações e projetos em parceria com o Serviço de Orientação Educacional (SOE) da escola e também com o professor de matemática e demais áreas. Atendendo à Base Nacional Comum Curricular (BNCC) que pontua a educação financeira como área transdisciplinar. Abordando o tema e levando os alunos a assumirem a prática de cidadania tendo a educação financeira como instrumento consciência social. A pesquisa será bibliográfica para fundamentar teoricamente a ideia futura do projeto de extensão. A ideia central do artigo é trazer a luz a educação financeira como necessária nas escolas, principalmente entre o público adolescente, referente ao Ensino Fundamental 2, uma vez que carecem de limites e podem atuar de forma reversa, ou seja, de forma consciente em seus projetos de vida, suas famílias e em sociedade. Demonstrando que pequenas ações planejadas de economia possibilitam poupar, investir e gastar de forma assertiva. 0 destaque para a reflexão do valor do trabalho, diferença entre valor e preço das coisas. E o principal para prática da cidadania que é a autonomia de tomar decisões coerentes em colaboração para mudanças de hábitos familiares.

Palavras-chave: Educação financeira, Consciência social, Adolescentes. 


\section{INTRODUÇÃO}

A escola é sede de várias temáticas transversais. A educação financeira não pode ser posta de lado. À medida que o foco educativo é transformar o aluno para a prática da cidadania, receber uma formação consciente relacionado às finanças colabora para uma mais uma intervenção social.

A educação financeira não é apenas para classes favorecidas financeiramente sobre perspectiva de investimentos e poupança. Ao oposto, uma necessidade para aqueles que precisam ter ciência de seus gastos e como bem distribuir.

A escola, por vezes, não enfatiza o ensino financeiro, perdendo a oportunidade de contextualizar o próprio ensino da matemática e usar desse assunto como elemento transdisciplinar. 0 recorte da presente pesquisa refere-se ao público adolescente (Ensino Fundamental 2) devido o lugar de diálogo mais maduro e atuante.

Uma vez que o aluno se apropria do funcionamento das finanças, cria-se o hábito de ator social, seja consumindo, investindo ou poupando. A fase da adolescência é marcada pelo ter através do apelo das mídias e pressão dos grupos. Apresentar ao adolescente a concepção de que para ter é preciso planejamento, demonstra valorização das coisas e desvia da futilidade.

Mais do que levar a educação financeira para sala de aula, provocar uma consciência financeira nos adolescentes para que possam agir com autonomia em suas vidas, famílias e socialmente. A proposta é atuar diretamente com o Serviço de Orientação Educacional e com o professor responsável pela disciplina de matemática para criar palestras, bate-papos, ações e estabelecer um vínculo com a Universidade diante de sua prática de extensão em contribuição dos Cursos de Pedagogia e Administração.

Levar educação financeira ao ambiente escolar através do público adolescente e criar laços com a universidade entre cursos especialistas na área permite que alcançar os propósitos acadêmicos de transdisciplinaridade e a prática de extensão universitária. Favorecendo um processo de ensinoaprendizagem significativo, conscientizador e de prática social.

A presente pesquisa é bibliográfica, a fim de levantar contribuições teóricas que fundamentem o desejo de transformar em um projeto de extensão universitária posteriormente.

A abordagem parte da conceituação do que é educação financeira; sua aplicabilidade em ambiente escolar; as características de Ensino Fundamental 2; as possíveis contribuições para uso de instrumento de conscientização social.

\section{0 QUE É EDUCAÇÃO FINANCEIRA?}

Nos dias atuais, não existe perspectiva sobre um mundo que todos têm consciência de quanto ganha, quanto pode gastar e a projeção para a realização de um sonho com o início de uma economia daquilo que se ganha.

Para nós, brasileiros, isto não acontece. Não temos a cultura de estudar nossa vida financeira e qual melhor atitude tomar. Isso reflete na vida de grande parte dos brasileiros, pois o descontrole financeiro gera $o$ endividamento crescente, mesmo com aqueles que têm uma boa renda, pois não adianta ganhar muito se não souber aplicar as premissas básicas de poupar.

A educação financeira é chave para o sucesso, independente da classe social, pois com ela, delimitamos e ajustamos a nossa realidade, o poder de compra e assim nos encaixamos com o perfil do nosso poder aquisitivo. 0 tema ainda é tratado como um tabu no Brasil, pois não há interesse de trabalhar estas questões em sala de aula. 0 consumo excessivo por crédito faz com que gerem lucro exorbitantes para o oligopólio de grandes instituições financeiras no país. Hoje, esse nicho de mercado tem se expandido cada vez mais com os bancos digitais, porém a população carece de entender o básico do sistema financeiro e como utilizar seus recursos da melhor maneira.

Dentro do lar da família brasileira, todo contexto de dinheiro é abordado num momento que família passa por dificuldades financeiras e a necessidade de corte orçamentário familiar, que muitas vezes atingem itens básicos da necessidade humana, porém é algo inevitável, pois falta estudo e planejamento para entender o que pode ser feito para não chegar neste momento crítico, e com isso criamos uma ideia equivocada sobre o tema educação financeira, até porque o intuito é trazer um conforto e segurança com o que se ganha. Precisamos entender que não seremos milionários ganhando 3 (três) salários mínimos, numa família de 4 (quatro) pessoas, porém administrando a renda, conseguimos uma segurança e proteção em momentos de dificuldades para aí sim buscar novas alternativas de aumentar a renda familiar. 
Com o conhecimento sobre educação financeira, você corre menos riscos de passar apuros em momento críticos, como no momento em que vivemos com a pandemia que assola nosso planeta.

Outra situação muito rotineira de quem arrisca falar de educação financeira é o termo poupar por poupar, porém este pensamento está errado. Quando traçamos metas financeiras, pensamos logo em quanto irei poupar e qual o destino darei para esta economia.

A educação financeira está relacionada à forma que entendemos sobre dinheiro e todas as formas de utilização deste recurso para que tenhamos uma vida mais equilibrada, pois o contrário disso pode afetar diretamente o convívio social, familiar e até o psicológico do indivíduo.

0 tema sobre educação financeira já é tratado há mais de 15 anos como prioridade pelos órgãos internacionais. A OCDE (Organização para a Cooperação e Desenvolvimento Econômico), no qual define sobre o tema:

"O processo mediante o qual os indivíduos e as sociedades melhoram a sua compreensão em relação aos conceitos e produtos financeiros, de maneira que, com informação, formação e orientação, possam desenvolver os valores e as competências necessários para se tornarem mais conscientes das oportunidades e riscos neles envolvidos e, então, poderem fazer escolhas bem informadas, saber onde procurar ajuda e adotar outras ações que melhorem o seu bem-estar. Assim, podem contribuir de modo mais consistente para a formação de indivíduos e sociedades responsáveis, comprometidos com o futuro".

A educação financeira tem como sua base principal, a conscientização do indivíduo em tomar decisões sensatas e corretas em todas as situações que envolvam dinheiro, sabendo de todas oportunidades e quais os riscos que corre, pois com este conhecimento, fica cada vez mais difícil perder tudo e alcançar o objetivo de forma saudável.

Quando você consegue enxergar o controle financeiro em sua vida, tudo fica mais leve, pois passa aquela obrigação de arrumar dinheiro de qualquer lugar, dividas e novos gastos que acontecem o tempo toda, desestimula o indivíduo a procurar um caminho melhor para trilhar.

As pessoas que se deram bem na vida financeira, provavelmente tiveram algum tipo de educação quando o tema é finanças pessoais. Isso não acontece em função do poder aquisitivo e sim o seu conhecimento sobre o tema. Muitas das vezes, pessoas com um poder aquisitivo bom, não mensura os gastos que têm que a melhor forma de empregar o dinheiro, para que ele tenha uma vida financeira.

Otimizar os ganhos é empregar e investir bem os recursos de uma maneira na qual possa garantir uma segurança e somente com a educação financeira poderemos obter esse benefício.

E muito além disso, a qualidade de vida para hoje e o futuro, vale de um determinado sacrifício, pois com ele, atingimos uma determinada segurança financeira com o intuito de aproveitar as coisas boas da vida e suprir a necessidade de um momento de dificuldade.

Existe fórmula para seguir uma boa educação financeira? Precisamos estudar todos os mecanismos que a estrutura financeira nos oferece, conhecer o mercado, o valor dinheiro e o principal, traçar metas para atingir este objetivo, que é uma vida financeira tranquila.

Nos próximos parágrafos, falarei sobre este planejamento a ser seguido, com base no estudo de finanças e sua educação.

Precisamos estabelecer objetivos que nos motive e a principal no qual sempre pensamos é a busca pela qualidade de vida no hoje e no amanhã, pois é uma meta natural no qual todos querem alcançar. Existem metas pequenas, como uma viagem no próximo ano, ou até mesmo a aquisição da casa própria, e com isso, precisamos apertar os cintos e seguir no objetivo que traçamos.

Traçando seu objetivo, o segundo momento é conhecer seus gastos, o que cortar, o que diminuir e o que precisa realizar para gerar mais renda. Este é o ponto principal para o início de uma virada da vida financeira. Ao conhecer e controlar seus gastos, você tem um auto domínio com seu dinheiro. Quantas vezes passamos o cartão e depois nem controlamos o que foi gasto, e tal conhecimento só vem quando a fatura chega?

A sensação que o dinheiro não deu é muito ruim, mas com este controle diário, conseguimos enfrentar este desafio. 0 controle dos gastos é o melhor remédio para reorganizar sua vida financeira. Já pensou em 
planilha de Excel? Lançamento diário como se fosse uma empresa? A melhor forma de entendermos para onde vai o dinheiro é contabilizar todas as saídas.

O corte é necessário e doloroso, até porque os prazeres da vida são muitos, e faz necessário um sacrifício para atingir metas bem maiores.

A próxima etapa é ter mais receitas do que despesa, o momento da economia e a balança começar a pesar mais para o lado positivo, faz com que seus planos mude e que você queira que o dinheiro trabalhe para você. Começa a terceira fase que é da multiplicação. Ao economizar e investir, suas metas serão alcançadas.

Nesta etapa, precisamos entender os tipos de investimentos, quanto teremos de retorno e quanto tempo este dinheiro ficará investido. Consigo desapegar deste valor por um tempo? Consigo arcar com situações eventuais para não perder todo meu esforço até aqui? Não pense que ao investir, você precise arriscar seu dinheiro, pois existem um portifólio de investimentos de remuneração média, investimento curto. Vale lembrar que não precisamos chegar na casa dos seis zeros para pensar em investir, sempre que as receitas forem maiores que as despesas, a hora de investir é essa.

Com todas estas etapas e tendo consciência que precisamos poupar para alcançar e o objetivo, o sucesso é certeiro e a educação financeira vem para isso, dar fomento para que você trabalhe de forma correta com o seu dinheiro.

\section{EDUCAÇÃO FINANCEIRA NO ENSINO FUNDAMENTAL 2}

No Brasil existe um Comitê Nacional de Educação Financeira (CONEF) que estabeleceu um projeto piloto no período entre 2008 a 2010 para abordar educação financeira nas escolas públicas para o público de Ensino Médio. A proposta é levar também para o Ensino Fundamental. Participam desse comitê, segundo o Ministério da Educação (2010):

O Conef é formado pelo Banco Central do Brasil (BCB), Comissão de Valores Mobiliários (CVM), Superintendência Nacional de Previdência Complementar (Previc), Superintendência de Seguros Privados (Susep), Ministério da Fazenda, Ministério da Educação, Ministério da Previdência Social, Ministério da Justiça, Associação Brasileira das Entidades dos Mercados Financeiros e de Capitais (Anbima), Bolsa de Valores, Mercadorias e Futuros (BM\&FBovespa), Confederação Nacional das Empresas de Seguros Gerais, Previdência Privada e Vida, Saúde Suplementar e Capitalização (CNSeg) e pela Federação Brasileira dos Bancos (Febraban).

Percebe-se uma formação de atuação e estratégias de intervenção da temática nas escolas públicas. 0 momento é favorável para propagação no ambiente escolar e especificamente ao Ensino Fundamental 2.

Em dezembro de 2010 foi estabelecido o Decreto № 7.397: “A estratégia foi criada para promover a educação financeira e previdenciária em razão do impulso às políticas de inclusão social no país" (MEC, 2010).

Além do Comitê Nacional de Educação Financeira atua em parceria o órgão de Estratégia Nacional de Educação Financeira (ENEF) que caminha para a 5a semana nacional de estímulo às ações de educação financeira nas escolas públicas e privadas.

Além dessa promoção nas escolas, o adolescente deve levar para casa o discurso de consciência financeira para colocar em prática.

Para o adolescente cercado pelas mídias, o estímulo à compra exacerbada de coisas supérfluas é tentador. Faz-se necessário compreender a diferença entre preço e valor. Mas principalmente demonstrar o valor do trabalho para chegar ao ganho, investimento e compra. Valorizando primeiro o próprio trabalho dos pais e posteriormente seu futuro trabalho para alcançar independência financeira.

Domingos (2012, p.8): "suas conquistas dependerão - e muito - da sua capacidade de lidar bem com o dinheiro. Isso porque, o dinheiro sempre foi, e continuará sendo, a mola que move o mundo".

o aluno precisa perceber que economizar traz benefícios. Ajudando sua família nas decisões sobre o orçamento é uma prática aconselhável e que pode reverter e uma mesada para que ele possa administrar. Economizar na conta de água, luz, nas compras para aplicar em outros aspectos, como por exemplo, para o lazer. 
O professor tem influência na formação do aluno para questões relacionadas à conscientização:

[...] o professor apresenta uma posição privilegiada no que tange a formação de hábitos, pois trabalha com crianças e adolescentes em um estágio no qual esses estão desenvolvendo conexões entre o seu comportamento e suas experiências vivenciadas (PREGARDIER, 2015).

Essa prática consciente financeira estimula o domínio de competências e habilidades matemáticas. Precisa planejar, comparar, calcular, estimar. Para além, desperta no adolescente limite e autonomia diante de suas ações.

“A educação financeira busca a modificação do comportamento das pessoas, desde pequeninas, quando ensina a escovar os dentes e fechar a torneira para poupar água e economizar. Isso é preceito de educação financeira" (FORTE, 2019). A escola deve apresentar conhecimentos básicos de educação financeira.

Ainda dentro do projeto proposto pelo governo para alunos de Ensino Médio de escolas públicas já é possível colher resultados comparando 2012 a 2016 :

Gráfico 1. Evolução do Programa de Educação Financeira nas escolas de ensino médio.

\section{Finanças nas escolas}

Evolução do programa no ensino médio
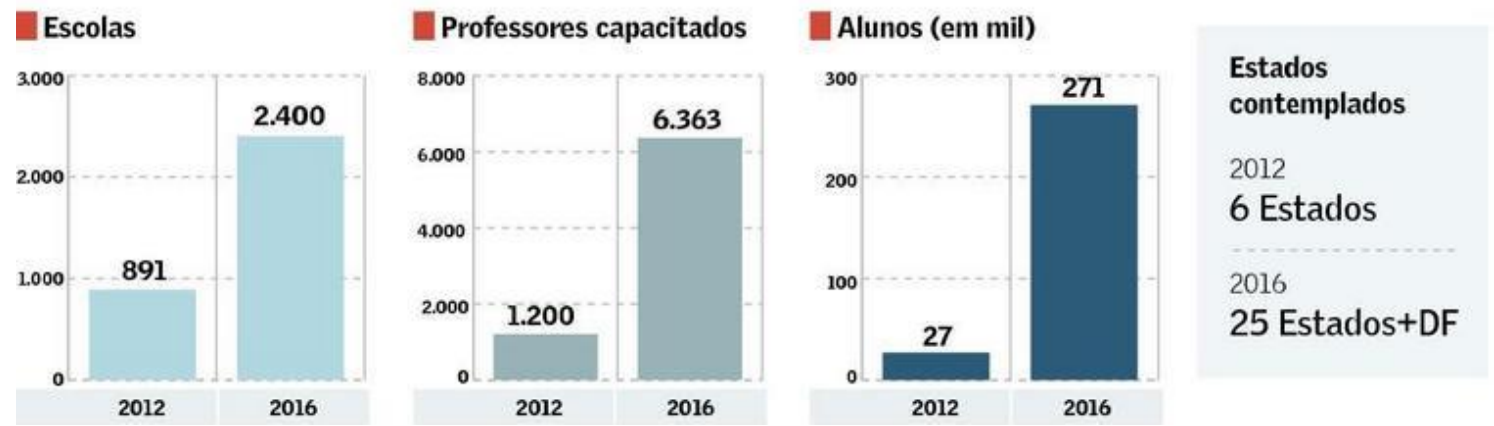

Fonte: AEF, Brasil (2016).

Todas essas estratégias desenvolvidas contribuem para uma educação financeira efetiva nas escolas com o passar dos anos. A educação financeira tem como papel o instrumento de conscientização social entre o público adolescente.

A ideia inicial dos cursos de pedagogia e administração da Universidade Estácio de Sá é colaborar no sentido de levar palestras e ações para as escolas públicas da cidade de Resende, Rio de Janeiro, por meio da proposta de um projeto de extensão.

Em um primeiro momento explicar o que é educação financeira. Em seguida levar exemplos práticos e instigar os alunos a serem disseminadores dessas ideias em suas casas e comunidade.

Demonstrando que a partir do que poderia ser um problema, pode-se tornar uma saída para soluções. A valorização do trabalho, dos recursos financeiros da família e o consumo consciente em parceria provocará mudanças habituais em seu convívio familiar. Seguindo orientações da Base Nacional Comum Curricular (BRASIL, 2017):

A Base estabelece conhecimentos, competências e habilidades que se espera que todos os estudantes desenvolvam ao longo da escolaridade básica. Orientada pelos princípios éticos, políticos e estéticos traçados pelas Diretrizes Curriculares Nacionais da Educação Básica. Assim, a Base soma-se aos propósitos que direcionam a educação brasileira para a formação humana integral e para a construção de uma sociedade justa, democrática e inclusiva. 
A educação financeira torna-se um instrumento de consciência social a partir do momento em que coloca esse adolescente no centro das tomadas de decisões e o instrumentaliza em competências e habilidades que antes desconhecia.

\section{CONSIDERAÇÕES FINAIS}

A educação financeira nas escolas como instrumento de consciência social conversa com a proposta transdiscisplinar da Base Nacional Comum Curicular (BNCC) e também ao movimento do próprio Ministério da Educação com estratégias para a educação financeira nas escolas públicas.

Invadir as famílias com mais uma temática cidadã que colobora para a tomada de responsabilidade dos adolescentes, público-alvo escolhido, auxilia a educação familiar em seus limites e na valorização do trabalho e de seus recursos financeiros.

O aluno passa compreender que literalmente "dinheiro não dá em árvore" e que ele precisa ser agente transformador caso queira lucrar.

0 mundo capitalista e a mídia induzem aos jovens o desejo por roupas, objetos de marcas que não são vitais. 0 consumo consciente atrelado à educação financeira mostra os bastidores dos gastos.

A consciência financeira instrumentaliza esse aluno para tomadas de decisões, desde o momento do planejamento até ao gerenciamento de sua renda. No caso, o aluno passa ser colaborador na vida financeira familiar. E se ele receber uma mesada terá a liberdade para fazer bom uso e também exercitar a questão do merecimento.

A proposta do projeto de extensão dos cursos de pedagogia e administração é contribuir com o Serviço de Orientação Educacional das escolas públicas da cidade de Resende-RJ e também atender aos professores de matemática em uma contextualização dos conteúdos da disciplina trazendo para a aplicabilidade da educação financeira.

\section{REFERÊNCIAS}

[1] AEF-BRASIL. Associação de Educação Financeira do Brasil. Disponível em: Acesso em: 20 ago. 2020.

[2] BRASIL. Decreto n.o 7.397, de 22 de dezembro de 2010. Institui a Estratégia Nacional de Educação Financeira - ENEF, dispõe sobre a sua gestão e dá outras providências. Disponível em: Acesso em: 20 ago 2020.

[3] BRASIL. Ministério da Educação. Secretaria de Educação Básica. Base Nacional Comum Curricular. Brasília: MEC/SEB, 2017.

[4] BRASIL. Projeto de Lei № 3.401/2004. Cria a disciplina "Educação Financeira" nos currículos de 5a a 8ª séries do ensino fundamental e do ensino médio. Disponível em: Acesso em: 20 ago. 2020.

[5] DOMINGOS, R. Ter dinheiro não tem segredo. São Paulo: DSOP Educação Financeira, 2012.

[6] PREGARDIER, A. P. M. Educação Financeira - Jogos para sala de aula: uma abordagem lúdico-vivencial de formação de hábitos. Porto Alegre: AGE, 2015.

[7] VIDA E DINHEIRO. ENEF - Estratégia Nacional de Educação Financeira. Disponível em: http://www.vidaedinheiro.gov.br/index.php> Acesso em: 30 ago. 2020. 


\section{Capítulo 6}

\section{Valores e ética na educação}

\section{Adriana Aparecida das Neves de Queiroz \\ Dayane Lima Viana}

Resumo: No presente trabalho se faz uma análise da situação que no momento se apresenta com relação a falta de valores éticos profissionais em uma grande porcentagem de nossa sociedade; se faz um levantamento de como os valores influenciam as pessoas, e como alguns dos fatores éticos podem contribuir em tão nobre causa. A "ética na educação" permite associar cada vez mais os direitos e deveres envolvidos no cotidiano do indivíduo na tentativa de que não se perca com o passar do tempo, ou seja, para encontrar um modus vivendi entre os valores pessoais, familiares, religiosos, profissionais, organizacionais e educacionais que são moldados na convivência em família. Esse ato educativo não é redutível a uma simples transferência de conhecimento: implica uma aprendizagem de valores e se apresenta, antes de tudo, no despertar de consciência das questões éticas do estar coletivo. Teoria e ação não são separáveis, a sua significação e aplicação são práticas para o bem dos outros e de toda coletividade. Ela pressupõe a consciência de suas nascentes e seus efeitos reais, objetivando adquirir ou inventar formas de ser ético sem perder de vista a necessidade de reflexão aprofundada sobre as motivações e os meios para construir e desenvolver uma humanidade justa. 


\section{INTRODUÇÃO}

Falar sobre o tema ética, no vasto campo da educação, não é coisa fácil. Essa palavra, que para Pascal exprime o "trabalhar para o bem pensar", pode sumariamente definir-se como "julgamento da apreciação sobre o bem e o mal". Esta definição coloca de imediato, ao menos na cultura ocidental, uma dupla problemática, as noções do bem e do mal. 0 praticante da educação visa promover certa moralidade promovendo os valores coletivos, e também reconhecer os fatores individuais que engajam a singularidade das populações concernidas como, por exemplo, família e política. Pense na seguinte questão, o seu governador ou seu presidente já foi cassado por corrupção, mas ainda assim foi novamente eleito, em sua opinião, como será a administração dos bens do povo nesse mandato? Você acredita que ele mudará a maneira de administrar? Ou ainda, se o árbitro que apitará a final de seu time de futebol já favoreceu por dinheiro certa equipe em um jogo, você acredita que ele será justo nessa partida?

Estas são algumas interrogações que poderiam aparecer quanto à falta de ética; existem inúmeras situações nas quais as faltas de valores podem levar a resultados imprevisíveis nas nossas vidas.

Deseja-se que os profissionais gozem de altos valores éticos, que os políticos eleitos para administrar os bens de toda a população sejam incorruptíveis, no primeiro que deve se pensar é em formar esses valores nas crianças e nos adolescentes, pois nessas idades é que podem se formar hábitos de conduta duradouros.

De acordo com os interesses ou o propósito que tenha uma pessoa para sua vida, ela vai criando determinadas ordens ou prioridades quanto aos valores a irem se formando, por isso considerará como mais prioridade tudo aquilo que o leve a alcançar sua meta, ou ao seu objetivo.

Um valor verdadeiro e universalmente aceitável é aquele que produz um comportamento que beneficia tanto a quem o exercita como a quem o recebe, e, por conseguinte a toda comunidade.

\section{DESENVOLVIMENTO}

A palavra valor pode significar merecimento, talento, reputação, coragem e valentia. Assim, podemos afirmar que os valores humanos são valores morais que regem a conduta das pessoas. Esses valores morais podem também ser considerados valores sociais e éticos, e constituem um conjunto de regras estabelecidas para uma convivência saudável dentro de uma sociedade. Segundo Wikipédia: Valores é o conjunto de características de uma determinada pessoa ou organização, que determinam a forma como a pessoa ou organização se comportam e interagem com outros indivíduos e com o meio ambiente.

Os valores são aqueles conceitos que podem ser postos na prática da nossa vida para que possamos viver melhor. Tanto em forma íntima, pessoal, familiar, grupal e social. Por isso todo valor é um conceito operativo. 0 ser humano não sabe viver sem esses parâmetros pelo qual na sua ausência os substitui com qualquer sistema de pensamentos o por diretrizes de alguma autoridade; por isso a busca instintiva de caudilhos e líderes na maioria dos seres humanos. Em geral uma criança exprime o desejo de ser como uma pessoa que ela admira, a professora de Português, por exemplo, elas sempre buscam um padrão a seguir.

Quando se fala em formação de valores, as maiores inquietações são de como conseguir expressá-los, como fazer para repassá-los para filhos, alunos e pessoas que não tiveram uma formação adequada; isso leva a importantes dificuldades na comunicação e o que é mais importante limita a integração de esforços para alcançar novas metas como é a de conseguir uma educação de alta qualidade do ponto de vista ético e profissional. De acordo com Aristóteles, existem duas espécies de virtude: a intelectual e a moral, sendo que nem uma nem outra estariam dadas à partida: em matéria intelectual, o lugar da formação seria o ensino; em matéria moral, a aptidão para a virtude decorreria da força do hábito, da prática, e, portanto, da ação social. Aristóteles não descarta, porém, o lugar da natureza na obtenção dos dons humanos. No tocante à virtude, sucederia outro movimento: é pelo exercício que se adquire a prática do bem ao praticar a justiça, tornamo-nos justos (Aristóteles, 1987, p. 27).

A partir dessa concepção, que sem dúvida é a formação das novas gerações com um alto valor ético e profissional aparece uma grande interrogação, quem é o responsável? E quem vai ser responsável por essa encomenda social? Pensamos que só se pode conseguir atingir essa meta com um trabalho acompanhado por diferentes instituições: 
- A escola.

- A família.

- A comunidade de estudantes.

- Os partidos políticos.

- As instituições religiosas.

- O governo: Federal, dos Estados e dos Municípios.

A comunidade de estudantes é de grande importância, pois eles estão representados por alunos unidos por interesses com objetivos e fins comuns; que possuem força capaz de reorientar, exercer crítica, estimular ante o êxito e trazer novas metas exercendo seu protagonismo e sentido de pertinência, companheirismo e coletivismo pelo bem-estar de todos. Mas quais são os valores que queremos que tenham as futuras gerações de brasileiras e brasileiros? Quais são esses princípios que consideramos indispensáveis para toda a população? Sabemos que esses são temas polêmicos, pois não tem por que coincidir os interesses dos diferentes partidos do que querem para o futuro do Brasil.

Ojalvo, Kraftchenho, González, Rojas (2003) ao falar dos valores indicam que: "O valor é um conceito de difícil definição por seu carácter complexo e porque constitui objeto de estudo de diferentes ciências, tais como a Filosofia, em suas ramificações da Ética, a Estética, a Sociologia, Psicologia, e a Pedagogia. 0 conceito de valor tem sido comparado com um poliedro, que têm múltiplas caras, que se pode analisar desde ângulos ou aristas diferentes".

Existem diferentes formas de classificação dos valores, mas será usada uma das mais universais, em que, segundo Wikipédia os valores humanos podem ser classificados como segue: Amizade, Companheirismo, Amor, Amabilidade, Autoestima, Caráter, Compaixão, Compreensão, Comprometer-se, Cooperação, Esperança, Ética, Força Interior, Fraternidade, Honestidade, Humildade, Igualdade, Justiça, Lealdade, Liberdade, Não discriminação, Não Julgar, Não Violência, Paz, Perdão, Perseverança, Respeito, Responsabilidade, Responsabilidade Social, Riqueza interior e exterior, Sinceridade, Verdade, Solidariedade, Tolerância. Alguns autores afirmam que nos dias de hoje a maior crise que o ser humano pode enfrentar (e que estamos enfrentando) é uma crise de valores, pois essa crise vai afetar a humanidade, que passa a viver de forma mais egoísta, cruel e violenta. Assim, é necessário enfatizar a importância de bons exemplos na sociedade, pois a transmissão de importantes valores humanos consiste a base de um futuro mais pacífico e sustentável.

Nos Parâmetros curriculares Nacionais para as séries ( $1^{\underline{a}}$ a $4^{\underline{a}}$ ) quando se colocam os objetivos a atingir nas disciplinas de Matemática e Língua Portuguesa, são indicados os valores que se pretendem formar nessas disciplinas, isso indica que é de interesse sim, a formação de valores. Mas não se pode pensar que para formar um determinado valor seja necessário acrescentar uma disciplina ou um determinado conteúdo, isso se deve conseguir nas aulas próprias das disciplinas que ministramos. Essa é uma das formas em que o governo federal pode contribuir à formação de valores. Mas em seu trabalho direto e nos seus discursos, um Prefeito, um Governador, um Presidente pode sem dúvidas formar valores, pois é um educador com um público alvo muito maior que, o que tem um professor em uma sala de aula. "Os valores humanos universais têm grande importância como princípios básicos de uma vida digna e de convivência social saudável e solidária, elementos essenciais para construção de uma cultura de paz, tão necessária à sociedade contemporânea". Colombo e Ruiz (2012).

No mundo unipolar no qual vivemos na atualidade os princípios, os valores as decisões estão nas mãos dos poderosos, é comum ouvir se não estas comigo, está contra mim, e para estar comigo tem que se solidarizar e apoiar as minhas decisões, isso é uma forma se submissão aos poderosos por parte do resto das nações.

Os processos globalizantes têm gerado mudanças sociais alterando formas de representação dos aspectos políticos, econômicos e culturais, considerando-se as relações de interdependência entre eles. Analisando as questões éticas da globalização, Freire $(1997,249)$ explicita a condição de submissão dos indivíduos aos valores globais e a interiorização dos seres humanos: A liberdade do comércio não pode estar acima do ser humano. A liberdade de comércio sem limites é licenciosidade do lucro. Vira privilégio de uns poucos que, em condições favoráveis, robustece seu poder contra os direitos de muitos, inclusive o direito de sobreviver. 
Na educação os valores são processos sistémicos, pluridimensional, intencional e integrado, que garante a formação e o desenvolvimento da personalidade consciente, se concreta através do curricular, extracurricular e em toda a vida social. Alonso (2000).

Consideramos que a educação com valores é um processo que se faz necessário incorporar como mais um componente do trabalho educativo de maneira explícita e intencional no processo de formação, pois os valores também se formam e desenvolvem automaticamente através da relação aluno-professor. Os valores interiorizados conformam a essência do modelo de representações pessoais, constituem o conteúdo d sentido da vida, e da concepção do mundo, permitem a compreensão, a interpretação e a valorização do sujeito e brindam a possibilidade de definir o projeto de vida, integrado por objetivos e finalidades para as atividades sociais. Para desenvolver no estudante um trabalho efetivo de formação de valores, é preciso, conhecer as determinantes internas da personalidade do estudante: interesses, concepção do mundo, atitudes, motivações, inquietações pessoais, etc.

As universidades desde suas origens têm sido a encarregada de formar profissionais e especialistas em diversas áreas do conhecimento, hoje deveria ser também encarregados da formação de autênticos cidadãos, responsáveis e comprometidos moral e eticamente com a formação das novas gerações de brasileiros dispostos a mudar para bem a realidade social que lhes rodeia.

"A concepção transformadora da educação possibilita denunciar a vulnerabilidade da escola a essas interferências e explicitar que a educação não apenas reproduz a ideologia dominante, mas propõe contra ideologias" [Severino, 2002]. A escola deve ficar na vanguarda das cobranças os seus representantes no governo nas diferentes instâncias do país, pois pode organizar as demandas e canalizar os critérios.

"É preciso repensar o curriculum, concebê-lo de uma nova forma, como espaços para a construção do conhecimento científico e sua inserção no desenvolvimento social, econômico e político do país, para a transformação social, para o diálogo crítico, a reflexão e a ação social, tendo como atividade central a investigação" [OJALVO, 2003].

Díaz (2003) indica que, no ensino de uma disciplina, em particular a disciplina de Matemática se pode contribuir fundamentalmente nos seguintes valores do futuro Profissional:

- Conhecimento do conteúdo da profissão,

- Vínculo afetivo com a profissão,

- Sentido de pertinência a uma profissão, imprescindível para o desenvolvimento econômico de seu país,

- Sentido de responsabilidade, discrição e confiabilidade,

- Capacidade de trabalho em coletivo,

- Amor à Pátria manifestado através de um Profissional capacitado, trabalhador, atualizado cientificamente, ocupado em resolver os problemas, capaz de sobrepor seus interesses pessoais aos ideais coletivos,

- Pensamento algorítmico,

- Pensamento criativo,

- Poder de abstração, organização e sistematização,

- Habilidade de modelação matemática da realidade objetiva.

Na medida em que o estudante deixa de ser um objeto de aprendizagem que repete mecanicamente a informação que recebe e se converte em um sujeito que processa informação e construí conhecimentos a partir de seus interesses e conhecimentos prévios, sobre a base de um processo profundo de reflexão no 
qual ele toma partido e elabora pontos de vista e critérios próprios, está em condições de formar seus valores.

Por outro lado o desenvolvimento do estudante como sujeito de aprendizagem e da educação de seus valores é possível na medida em que o docente desenhe situações de aprendizagem que propiciem que o estudante assuma uma posição ativa; reflexiva, flexível, perseverante, em sua atuação. Por isso é importante o carácter orientador do docente na educação e na formação e desenvolvimento dos valores.

Dessa forma constatamos que o comportamento e as práticas humanas contemplam a diversidade cultural, por mais que as sociedades modernas se caracterizem por processos homogeneizadores. Bizzochi (2003, p.13) complementa esta visão sobre cultura ao expor: "Num sentido amplo, cultura é tudo aquilo que no homem não é fruto exclusivo da herança genética, é tudo que ele aprende e transmite aos outros homens pela linguagem". As crianças aprendem o que vem o que ouvem e o que vem fazer, por isso não é casual ouvir a uma criança dizer, quando seja grande eu serei traficante; isso é um reto mais que tem a educação em um país tão grande e diverso.

Os debates contemporâneos sobre a relação do conhecimento científico e as possibilidades técnicas de seu uso para manipulação da vida nos mostram que a preocupação ética é coetânea ao próprio pensamento. Mesmo assim, como diz Cortina (2003, p. 18), "embora a ética esteja na moda e todo mundo fale dela, ninguém chega realmente a acreditar que ela seja importante, e mesmo essencial para viver".

\begin{abstract}
"Um dos conflitos fundamentais no campo da moral está ligado à natureza ambivalente do ser humano, que tanto é ser individual quanto social. A estas duas faces do humano ligam-se duas estratégias da formação moral uma das quais privilegia o aspecto subjetivo/individual e a outra o aspecto intersubjetivo/social". Goergen, $\mathrm{P}$ (2005).
\end{abstract}

Os valores são produto de mudanças e transformações ao longo da história. Surgem com um especial significado e mudam ou desaparecem em épocas distintas. Por exemplo, a virtude e a felicidade são valores; mas não poderíamos ensinar as pessoas do mundo atual a serem virtuosas segundo a concepção que tiveram os gregos da antiguidade. É precisamente o significado social que se atribui aos valores um dos fatores que influenciam para diferenciar os valores tradicionais, aqueles que guiaram às sociedades no passado, geralmente referidos a costumes culturais os princípios religiosos, e os valores modernos, os que compartem as pessoas da sociedade atual.

Segundo Martha e Nuris (2012), a objetividade do valor transcende os interesses particulares. Mas isso não é suficiente, sua objetividade depende da subjetividade e seu carácter social, da individualidade, e viceversa, querer dizer, que no centro da compreensão dos valores estão as relações entre o objetivo e o subjetivo e entre o individual e o social.

Muitas das tentativas e experiências por alcançar uma maneira que eduque em valores (entendido o termo como educar sobre os valores, intencionando-os dentro das ações formativas), podem fracassar quando não se tem claridade do antes exposto, posto que poderia desvirtuar-se o objetivo da própria educação, exemplo disso:

- Quando se pensa que explicando fatos históricos e atuais da realidade, ou incorporando novas disciplinas por si só, seu conhecimento produz valores o mudança na conduta e personalidade do sujeito, é dizer, que só mediante saberes se formam e desenvolvem os valores.

- Quando se buscam comportamentos em fatos isolados, como participação em atividades orientadas, sem objetivos bem definidos, nem compreendidos e assumidos pelo sujeito tanto no racional como no emocional.

- Quando se pensa que formar e desenvolver valores segue as mesmas regras da aprendizagem de conhecimentos e habilidades.

- Quando se considera que não é necessário incorpora-los como um componente de trabalho educativo de maneira explícita e intencional no processo de formação, pois eles se formam e desenvolvem automaticamente a través da correta relação aluno-professor. 
Os valores são os resultados de uma compreensão nem, muito menos de una informação passiva, nem de atitudes conduzidas sem significação própria para o sujeito; é algo mais complexo e multilateral, pois se trata da relação entre a realidade objetiva e os componentes da personalidade, o que se expressa a través de condutas e comportamentos, por tanto, só se pode educar em valores a través de conhecimentos, habilidades de valoração, reflexão na atividade prática com um significado assumido. Trata-se de alcançar comportamentos como resultado de aprendizagens conscientes e significativas no racional e no emocional. O problema dos valores tem sido tratado desde a aparição da Pedagogia, a modo de exemplo colocaremos o pensamento patriótico, moral e ético de destacados pedagogos cubanos do século XIX, quem já indicavam que a função do professor não era só instruir transmitindo os conteúdos que a ementa de sua disciplina continha, nessa direção os trabalhos de José Martí Perez, Félix Valera Morales e José de a Luz e Caballero são significativos, em suas obras e em suas aulas transmitiam os valores essenciais que deveria ter o ser humano.

A incapacidade da escola em atender as necessidades dos jovens e as dificuldades encontradas pelos gestores em aspectos como uma organização que estimule a aprendizagem, são a causa direta de uma nova desigualdade social. Mais genericamente, a atividade em todas as áreas e em todos os níveis da hierarquia educacional apresenta-se com um nível de complexidade sem precedentes. Há outro fator, não menos importante: o abandono da autoridade do professor. Essa nova forma de anarquismo que coloca nas penas do anti-autoritarismo eleva a criança ao nível mais alto, em ser dada prioridade à sua livre expressão, sustentado na premissa do risco de limitar a sua criatividade, ou pior, estigmatizá-la. Assim, o estudante foi colocado no centro da escola, passando de um desequilíbrio para outro, pois a figura do professor e do conhecimento tornou-se, agora, marginais ao sistema. (Chevenement, 2006).

Contudo, não se deve perder a perspectiva de que crianças e adolescentes também são educados por suas famílias, portanto, não cabem ao professor nem todos os méritos, nem todos os deméritos pelo resultado do processo educacional.

A escola, na opinião do autor citado, tem como objetivo básico ensinar, e não, fazer os alunos felizes, não se descartando a possibilidade de que um pode causar o outro. Nós corroboramos com a ideia de que, em muitos momentos, a escola já não se destina fundamentalmente a educar os alunos e que, segundo Nóvoa (1999), a escola está se tornando cada vez mais uma instituição social assistencialista, e os professores, também, em muitos momentos, atuam com assistencialismo cada vez maior. A escola pública, basicamente, aceita esse grande naufrágio.

No processo educativo a formação de valores deve ser entendida como processo de enriquecimento da personalidade no qual deve conseguir uma aproximação cada vez maior entre o sistema subjetivo de valores como reflexo dos interesses gerados pela sociedade em seu conjunto, mantendo o carácter real, individual na formação e desenvolvimento da personalidade a partir do comprometimento do sujeito com o que assume como valor. (Garcia, 2010)

Foi realizada uma pesquisa com 12 (doze) perguntas através de questionários a 186 estudantes de licenciaturas variadas de uma universidade, 24 professores do ensino fundamental, médio e superior, e 15 detentas de um presídio na cidade de Tabatinga, foram selecionadas duas dessas questões constatou-se uma realidade interessante. A primeira pergunta foi:

A escola é importante na formação de valores?

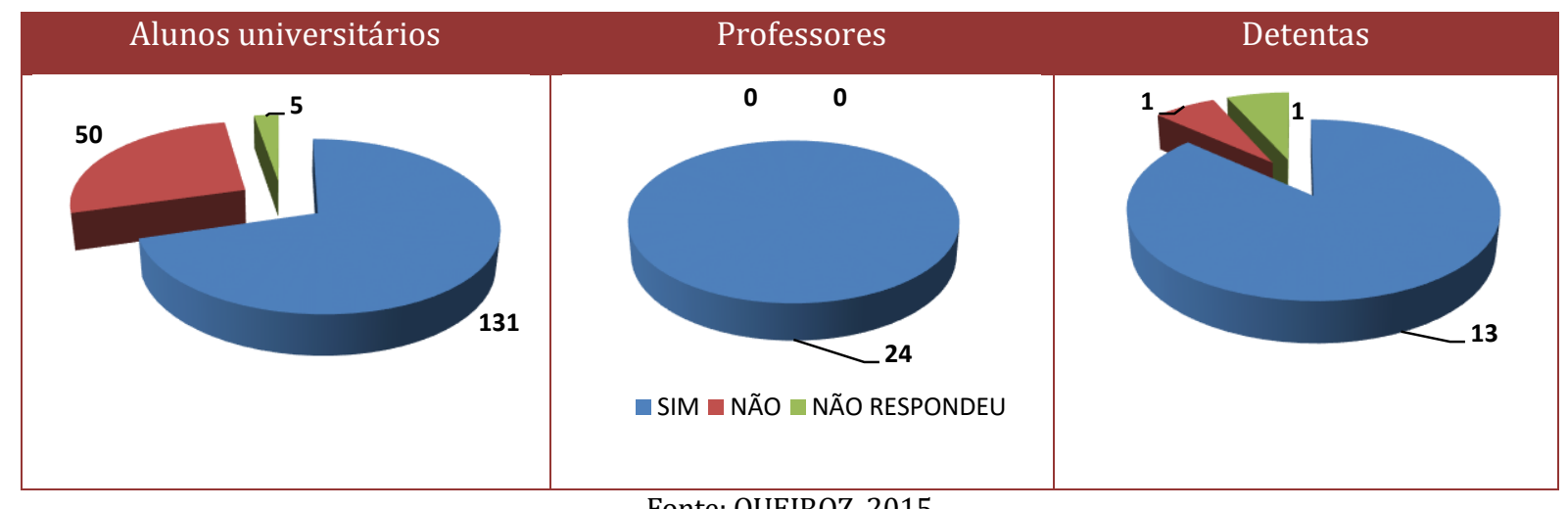


Como demonstra o gráfico acima, 131 alunos que pretendem ser professores responderam que a escola é importante na formação de valores, e 50 responderam que a escola não é importante na formação de valores; o que chega ser preocupante, pois esses discente serão professores, em princípio formadores de opinião. Já os professores foram unânimes em afirmar que a escola é sim importante na formação de valores de seus alunos, o que é de importância fundamental, pois as crianças e adolescentes passam um tempo considerado em companhia desses profissionais. As presidiárias que participaram da pesquisa são de profissões variadas e de idade entre 21 a 30 anos, e na opinião delas a escola tem grande importância na formação de valores de um indivíduo.

A segunda pergunta, desta pesquisa, foi sobre a influência da família sobre a criança, em que se questionou o seguinte:

A família consegue influenciar na formação de valores das crianças?

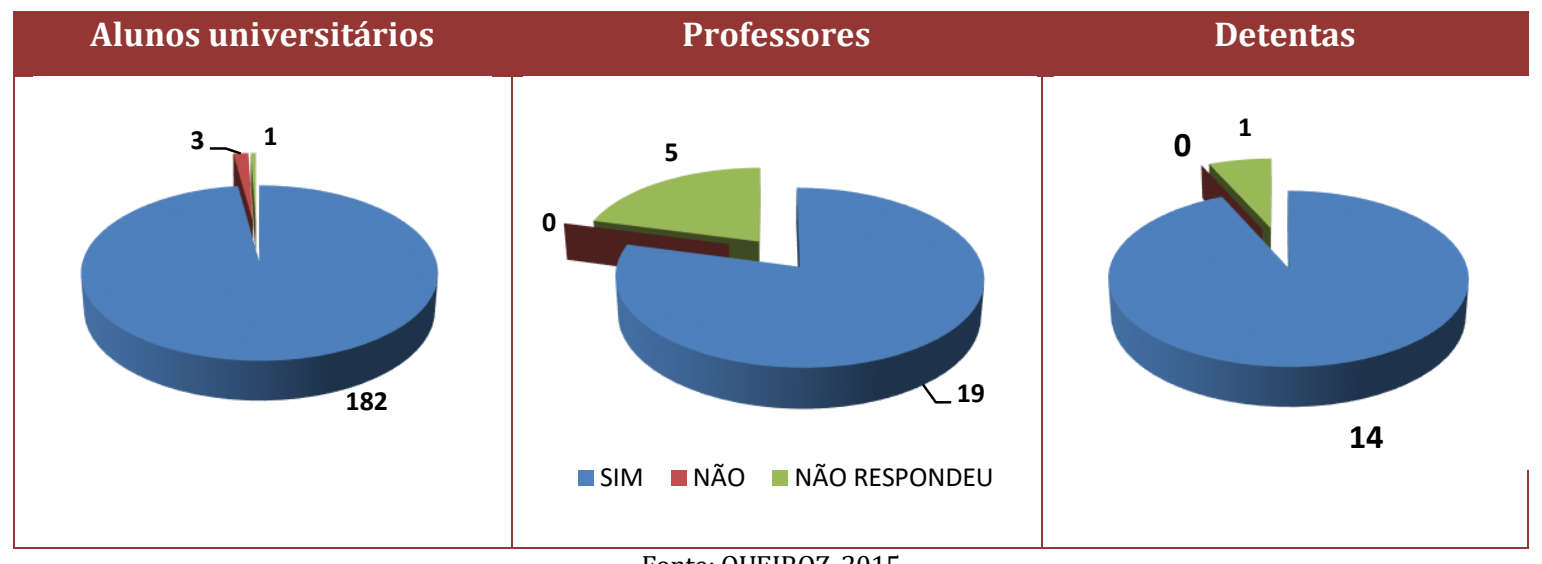

Fonte: QUEIROZ, 2015

Nessa questão a grande maioria dos entrevistados tem o mesmo ponto de vista, a família é a principal influenciadora na formação de valores das crianças, partindo desse pressuposto pode-se afirmar que a criança tem a família como espelho, é o seu principal referencial, seu modelo a ser seguido. Com isso pode-se afirmar que é pela prática constante de observação de um ente que se admira, que se adquire os valores, sejam eles bons ou ruins, pois Aristóteles (1987, p. 27). diz que, "a noção de potência remete-se ao futuro reservado pela natureza. 0 adulto seria, então, a anterior criança que atualizou em ato sua potencialidade original. Nesse sentido, para se tornar bom, deve-se praticar atos bons. A ética seria, assim, matéria da ação, o território ético firma-se, por definição, na prática, no hábito e no exercício. Não se forma o ser ético exclusivamente pelo conhecimento ou pela disposição do intelecto. A ética fala de perto ao espírito e à alma; e só pode ser reconhecida quando praticada".

\section{CONCLUSÃO}

Os temas ética e educação são de grande importância, por isso são assuntos que estão sempre abertos para contínua discussão, mas o que é indiscutível é a condição do ser humano, depende dele o bom ou mau comportamento para o convívio em coletividade. Ficou claro com a pesquisa que os valores éticos tem que ser trabalhados desde a infância, tanto na família quanto na escola nas séries iniciais.

A criança tem a família como principal exemplo a ser seguido, a criança tende a querer "imitar" e seguir os exemplos do familiar mais próximo e que demonstra ter mais liderança em casa. Logo em seguida vêm as pessoas da escola, segundo ambiente que a criança passa horas em convívio com seu professor, e este acaba sendo uma pessoa ao qual a criança passa a admirar e confiar; e muitas vezes passa a agir e até mesmo imitar o seu professor.

Com isso se faz imperativo que pais, familiares, professores e diretores devem ter comportamento ético, e serem exemplos de inspiração das crianças no que diz respeito ao desenvolvimento de valores e atitudes positivas de conduta que perdurem por toda vida, portanto, Ferreira (p. 70) enfatiza que além da família e sociedade a escola deve fornecer os seguintes critérios "saber o certo e o errado, o bem e o mal" são valores de juízo pessoal aos quais a escola tem o papel de intermediar para o convívio em sociedade, ou seja, como agência formadora tem o importante papel de torna-se uma ferramenta de inserção de valores éticos na 
esfera individual e na vivência de cada discente o que acarretará na transformação do meio coletivo e na realidade em que vive.

\section{BIBLIOGRAFIA}

[1] ALONSO, Isabel. “Formación de valores”. UO. (2003).

[2] ARISTÓTELES. “Ética a Nicômaco”. Coleção Os Pensadores, vol. II. São Paulo: Nova Cultural, 1987.

[3] BIZZOCHI, A. Anatomia da Cultura: uma nova visão sobre ciência, arte, religião, esporte e técnica. São Paulo: Palas Athena, 2003.

[4] CHEVÈNEMENT, J. P. Pas de société du savoir sans école. Intervention prononcée lors du colloque. Paris, 2006.

[5] COLOMBO, Sophie Viviani Colombo e DUMARA, Nadia. RUIZ, Silveira. Valores humanos e educação em escolas públicas da cidade de São Paulo. Faculdade de Educação (2012).

[6] CORTINA, A. O fazer ético. São Paulo: Moderna, 2003.

[7] DÍAZ, Jorge. "Sobre la contribución a la formación de valores de estudiantes profesionales a partir de una asignatura universitaria". UO. (2003).

[8] FEREIRA, Nair Gurgel do Amaral; TEZZARI, Neusa dos Santos. Leitura e linguagem: discurso e letramento. Porto Velho: EDUFRO, 2006

[9] FREIRE, P. Globalização Ética e Solidariedade. In DOWBOR, L., IANNI, O. (1997).

[10] GARCÍA, Sonia Jerez. La formación de valores, una problemática actual. Sus antecedentes en la pedagogía cubana de vanguardia del siglo XIX Instituto Superior Pedagógico de Granma. (2010).

[11] GOERGEN, Pedro. Educação e valores no mundo contemporâneo. UNICAMP. (2005).

[12] DÍAS, Jorge. “Sobre la contribución a la formación de valores de estudiantes profesionales a partir de una asignatura universitaria". UO. (2003).

[13] LUZ y Caballero, JOSÉ de la. Escritos educativos/ José de la Luz y Caballero. La Habana: Ed. Pueblo y Educación, 1991. 299 p.

[14] MARTI, Pérez Posé. Ideario Pedagógico/ José Martí Pérez. La Habana: Ed. Pueblo y Educación, 1990. 147p.

[15] MARTHA, Arana Ercilla; NURIS Batista Tejeda. La educación en valores: una propuesta pedagógica para la formación profesional. ISPAJAE-CUBA. (2012)

[16] NÓVOA, A. Profissão Professor. 2ª ed. Porto: Porto Editora, 1999.

[17] OJALVO, Victoria Mitrany. OKSANA Kraftchenho Beoto, VIVIANA González Maura, ANA Rosa Rojas Rodríguez. Conceptualización general de los valores. Revista Pedagogía Universitaria. Vol. 8 No. 1. (2003).

[18] OJALVO, Victoria Mitrany: La educación de valores en el contexto universitario. Capítulo III: Educación de valores. Pedagogía Universitaria, Vol. VIII, No. 1. Año 2003. ISSN 1609-4808

[19] NACIONAIS, Parâmetros Curriculares. Séries (1ra a 4ta).

[20] PEDRO, Goergen. Educação e valores no mundo contemporâneo. UNICAMP. (2005).

[21] SEVERINO, A.J. Educação, sujeito e história. São Paulo: Olho d'Água, (2002).

[22] SOPHIE, Viviani Colombo e NADIA Dumara Ruiz Silveira. Valores humanos e educação em escolas públicas da cidade de São Paulo. Faculdade de Educação (2012).

[23] SONIA, García Jerez. La formación de valores, una problemática actual. Sus antecedentes en la pedagogía cubana de vanguardia del siglo XIX Instituto Superior Pedagógico de Granma. (2010).

[24] VARELA, Morales, Felix. Miscelánea Filosófica/ Félix Varela Morales. Ciudad de La Habana: Ed. Pueblo y Educación, 1992. 181p. 


\section{Capítulo 7}

\section{A identidade nacional brasileira na educação formal}

\section{Amanda Marques de Carvalho Gondim}

Resumo : 0 artigo faz uma reflexão acerca do conceito de identidade nacional no contexto da educação formal. Conceituar identidade nacional por vezes se aproxima do senso comum a partir da compreensão de alguns elementos culturais presentes na sociedade e apropriado por determinados grupos. 0 objetivo é apresentar o sentido dado pela educação formal ao conceito de identidade nacional brasileira. A afirmação de um discurso com base nas tradições culturais do povo brasileiro leva à aproximação com o enunciado religioso. Foucault e Elias encontram aproximações teóricas nesse sentido, principalmente na percepção dos diversos ângulos percorridos em uma pesquisa para o entendimento dos mecanismos sociais e da sociedade como algo em constante mudança. A metodologia utilizada é a análise de documentos publicados pelo Ministério da Educação em dois momentos, 1984 e 2017. Os documentos de 1984 foram dois boletins da Comissão Nacional de Moral e Civismo, responsável pela Educação Moral e Cívica, e o de 2017 foi a Base Nacional Comum Curricular, na área de conhecimento do Ensino Religioso. Encontra-se em ambos a importância de um ensino voltado para a moralidade e religiosidade, considerados importantes na educação formal. 0 resultado é a permanência de uma afirmação no espaço da educação formal no qual o processo não planejado de unicidade religiosa, assim se torna, por meio da interdição.

Palavras-chave: Identidade nacional, Educação formal, Comissão nacional de moral e civismo, Interdependência, Análise do discurso. 


\section{INTRODUÇÃO}

O conceito de identidade nacional ocorre por meio de uma construção social e a educação aparece na condição de espaço para formação e afirmação nas gerações mais jovens da sociedade. Souza (2017, p. 10) considera que a identidade nacional brasileira foi forjada a partir de Gilberto Freyre, no sentido de compartilhamento por todos os brasileiros do seu significado. Isso só foi possível a partir de um sentimento "que permitisse algum 'orgulho nacional' como fonte de solidariedade interna". Gondim (2017) afirm ou que a escola brasileira dos anos 1960 e 1970 buscou elementos similares aos já apontados por Gilberto Freyre, considerando a origem da nacionalidade no episódio das batalhas dos Guararapes, ocorrido no século XVII, quando o país ainda era colônia de Portugal.

A identidade é objeto de várias ciências, embora tenha tido maior inquietação nas salas de aula principalmente com o advento de debates sobre multiculturalismo. Um ponto em comum ocorre na maioria deles: a identidade é uma construção social e se relaciona com o ambiente onde o indivíduo está inserido (SILVA; SILVA, 2006). Assim, a identidade nacional ocorre com a correlação de identificação a um passado comum das diferentes pessoas que vivem na sociedade. É por meio dessa aproximação em torno da ideia de um passado comum que um país encontra discursos na formação educacional para a afirmação e existência do povo.

Nas escolas brasileiras do século XX, a história que promoveu uma identidade nacional possuía caráter acrítico. Desse modo, a formação de uma cidadania brasileira ocorria nos moldes positivistas de demonstração de fatos e personagens escolhidos pela elite para representar o que significava ser brasileiro. O relatório da UNESCO de 1996 trouxe como um dos subtemas a educação cívica. Nele, consta que "o sistema educativo tem, pois, por missão explícita ou implícita, preparar cada um para este papel" (UNESCO, 1998, p. 60). A ação cívica corresponde ao envolvimento do educando nas etapas do seu processo de aprendizagem, de forma crítica e democrática.

Durante muito tempo na educação brasileira foi pautada numa doutrina de segurança nacional, compreendendo principalmente no ensino de ideias consideradas não subversivas. Tudo que parecia conjurar contra a identidade nacional poderia ser considerado subversivo. Assim, os principais elementos afirmados como pedra fundamental da nação brasileira não deveriam ser questionados ou mesmo debatidos.

0 processo de redemocratização brasileira trouxa à tona a discussão de como ensinar cidadania para a formação integral do estudante. A identidade nacional passa a ser um viés desse debate, pois traz consigo os conceitos basilares da construção do cidadão, em seus valores e preceitos. Problematizar como a ideia de nacionalidade vem sido promovida no ambiente escolar é necessário para avançarmos em um dos vieses mais importantes da educação. Entender qual o papel da educação na identidade nacional e como ela se apresenta nesse processo faz-se mister para desenvolvermos ainda mais uma educação voltada para a participação social, sem desconsiderar o sentido ao qual o indivíduo encontra-se inserido.

\section{METODOLOGIA}

O percurso metodológico utilizado foi a análise de dois boletins elaborados pela Comissão Nacional de Moral e Civismo (CNMC) no ano de 1984, publicados e divulgados pelo Ministério da Educação. O segundo documento foi a Base Nacional Comum Curricular (BNCC), mais especificamente a área de Ensino Religioso (ER), publicada pelo Ministério da Educação no ano de 2017. Os dois boletins encontram-se na Biblioteca Nacional, no Rio de Janeiro. 0 primeiro foi publicado para os meses de janeiro a junho e o segundo, de julho a dezembro de 1984, em pleno processo de reabertura democrática. A BNCC encontra-se no site do Ministério da Educação, na internet, de fácil acesso a qualquer pesquisador.

Os primeiros documentos foram elaborados em um período de reabertura democrática na política brasileira e encontram uma maneira de divulgar as atividades realizadas em todo o país no âmbito da Educação Moral e Cívica (EMC). Com isso, corrobora a ideia de manutenção da cultura nacional por meio de discursos e práticas a serem copiadas nas salas de aula do Brasil. A BNCC, finalizada e divulgada em 2017 como resultado de um debate que ocorreu desde a Constituição Federal da República Federativa do Brasil de 1988 (CF de 1988), representou a principal diretriz a ser seguida pelas escolas de todo país. Em sua introdução, menciona ser um documento norteador das "aprendizagens essenciais" (BRASIL, 2017, p. 7) a serem desenvolvidas no processo educacional. Inserir uma área, de ensino religioso, como algo a ser ensinado e aprendido no decorrer dos 9 anos do ensino fundamental merece, no mínimo, uma reflexão sobre sua função na formação cidadã. Considerar a importância do ensino religioso no país, figurada como um parágrafo na CF de 1988, é não menosprezar o papel da religião na afirmação da identidade nacional. 0 ensino religioso 
ressurge como afirmação de "parte integrante da formação básica do cidadão" (BRASIL, 1997) na Lei de Diretrizes e Bases da Educação Nacional (LDBEN), por esse motivo tratada na elaboração e afixada na condição de área pela BNCC.

Na análise do discurso, o que se procurou nos documentos foi a aproximação entre o que se entendia por identidade nacional em contraponto ao que se considerava diversidade cultural. Tendo sido a comissão um órgão do governo federal responsável pelo que deveria ser ensinado a partir da moral e bons costumes brasileiros, suas publicações produziram e reproduziram as atividades realizadas nas escolas brasileiras dos anos 1970 e 1980. Do mesmo modo, ao elaborar a BNCC em 2017, procura-se direcionar os discursos a serem reproduzidos na educação.

\section{REFERENCIAL TEÓRICO}

Elias (2006) desenvolveu uma teoria dos processos sociais considerando um diagnóstico e explicação de tendências de longo prazo não planejadas. Apesar disso, devem ser organizadas e orientadas a partir do desenvolvimento das estruturas de sociedade e personalidade. Para tanto, deve-se desconstruir na sociologia que ela represente uma análise de curto prazo da sociedade, relegando o longo prazo à história. Desse modo, não é possível compreender aspectos do nosso dia a dia promovidos a partir de processos não planejados de longa duração temporal.

Sua teoria procurou mostrar que o pensamento humano é desenvolvido por meio da convivência humana e, como reflexo, a sociedade humana desenvolve-se com esse contato. Assim, "a sequência de tipos de pensamento repousa na sequência de etapas do desenvolvimento da sociedade" (ELIAS, 2006, p. 198). Com isso, ampliou a singularidade dos seres humanos para algo que inclui o relacionamento de uns com outros "e, com isso, também sua corporalidade, a necessidade de se sustentar e de trabalhar para esse fim" (ELIAS, 2006, p. 198).

Então, qual o papel da sociologia, na perspectiva de Elias? "Pesquisar e estudar tais estruturas de interdependência e processos" (ELIAS, 2006, p. 204). Deve-se partir da ausência de atos meramente voluntários de seres individuais. É comum atribuir a resultados naturais elementos provocados pela ação humana na natureza. Um exemplo dado por ele é o da poluição na atmosfera, excluindo o debate acerca da sociedade que a produziu; assim como as armas de guerra são um problema das ciências sociais, o é o da poluição atmosférica.

0 que se entende por desenvolvimento é atribuído nas ciências sociais europeias apenas às sociedades "menos desenvolvidas", pois há uma observação em Elias de que os países europeus "desenvolvidos" possuem uma "história", como se tivessem chegado a um ponto de irreversibilidade. Mas isso é visto como preocupante por parte de Elias, pois considera a observação dessas pessoas acerca da própria história de maneira linear, como um caminho a ser seguido e que, ao chegar no estágio final, não haveria mudanças.

Compete à teoria da civilização trazer "o problema das mudanças de longo prazo das estruturas da sociedade e das estruturas da personalidade" (ELIAS, 2006, p. 207). Para tanto, é importante desvencilharse do pensamento de linearidade, compreendendo o processo civilizador como algo que corresponde à sua compreensão em um dado momento, mas que não significa algo melhor ou pior com o passar do tempo. Existe uma forte aproximação entre a história e a sociologia, embora a primeira possua resistência em afirmar que a história estudada seja a história das sociedades. Por sua vez, a sociologia tem-se preocupado com recortes menores, embora buscando elaborar afirmações de longa duração. Provoca, assim, uma dicotomia, reservando à história o papel de pesquisar o passado e à sociologia, o presente; a sociedade é apresentada pela ciência, portanto, como algo que não possui conexão com o indivíduo.

Essa aparente "confusão" entre as duas ciências depende inclusive do estágio de desenvolvimento da sociedade na qual estão inseridas. Um exemplo citado é a concepção de materialismo histórico, cuja teoria envolve passado, presente e futuro, sem deixar de ser considerado histórico. Importante lembrar que o percurso metodológico que levou o historiador a proferir afirmações em um dado contexto, podem em outro momento deixar de ser levado em consideração. Isso ocorre porque "a perspectiva pessoal a partir da qual a narrativa foi escrita mudou de acordo com as transformações nas questões do dia" (ELIAS, 2006, p. 214).

A pergunta é: que transformações são essas que implementam modelos e formas de percepção que alteram a sociedade? Não se trata de julgar se são boas ou ruins, mas entendê-las para explicá-las. Apenas após concluída essa etapa é que seremos capazes de analisar quais sociedades produziram modelos com mais ou menos vantagens para a humanidade. Deve-se ter muita atenção ao realizar e observar planejamentos de 
curto prazo nos seus reflexos não-planejados de longo prazo. A ausência de conexão nas pesquisas gera um imediatismo que, para Elias, não corresponde a uma compreensão mais clara do acontecimento social.

0 processo de especialização funcional pode ser considerado como algo que faz parte desses acontecimentos "não planejados". Na divisão social das funções, cada vez mais diversificada e complexa na sociedade ocidental, há algo que se direciona para uma dada configuração. Quanto mais desenvolvida é a sociedade, maior o número de especialidades e nominações das atividades realizadas individualmente.

Como resultado da evolução industrial, podemos apresentar a existência de mais nomenclaturas para as funções do que em qualquer outro momento da história das sociedades. Na academia essa situação não está diferente. Com o esforço cada vez maior em se especializar nos diversos ramos científicos, os cientistas findam por se individualizar ao ponto de não considerar a interdependência inerente ao próprio convívio em sociedade e as produções intelectuais que antecedem ao conhecimento científico desenvolvido por pessoas individuais. Embora esse acontecimento ocorra em menor proporção nas ciências físicas do que nas humanas.

No caso específico da sociologia, Elias concorda que "desenvolvem-se atualmente mais e mais especializações, cujos representantes com frequência esforçam-se na busca de uma teoria geral da sociedade da perspectiva de seu domínio particular" (ELIAS, 2006, p. 222). Como resultado, as dificuldades de comunicação. Outro aspecto não planejado pelas sociedades diz respeito ao comportamento humano do que é permitido ou proibido em uma dada configuração social.

Quanto a isso, Foucault (2008) traduz na Ordem do discurso como as interdições. 0 conceito de interdição é considerado por ele como um dos procedimentos de exclusão. Segundo essa ideia, as sociedades, por meio de suas instituições detentoras de poder, estabelecem o que pode e não pode ser dito, revelando não apenas os sistemas de dominação, mas "aquilo por que, pelo que se luta, o poder do qual nos queremos apoderar" (FOUCAULT, 2008, p. 10). Relacionando um e outro, é possível perceber aproximações não apenas sobre o que é permitido ou proibido, mas perceber as possibilidades de continuidades e descontinuidades nas civilizações ao longo do tempo.

Para Elias, entender o processo civilizador perpassa pelo entendimento das transformações não planejadas, tanto das estruturas sociais quanto da personalidade "e como elas podem ser explicadas" (ELIAS, 2006, p. 225).

Em outras palavras: a coexistência casual e não-estruturada de pessoas e eventos, que o historiador descreve em narrativas, desenrola-se no quadro de mudanças sociais estruturadas e de longo prazo. Desenvolver modelos teóricos dessas mudanças estruturadas e direcionadas, embora não planejadas e sem finalidade, e fundamentá-los com evidências mais abrangentes, permanece uma tarefa científica que, em grande parte, ainda está diante de nós (ELIAS, 2006, p. 226).

Ao evidenciar um problema, os indivíduos procuram solucioná-lo e, ao observar isso na coletividade é que se torna possível compreender os processos sociais. Para isso, deve-se desvencilhar da condução metodológica que observa como história ou teleologia. Não se deve esquecer, ao tratarmos os processos sociais na condição de progresso ou desenvolvimento, que essas palavras não recaiam no sentido positivista até então entendido. Os processos humanos devem ser explicáveis pelas ciências no sentido de acontecimentos sem finalidade.

É necessário salientar que essa metodologia não deve desconsiderar os sentidos valorativos conferidos pela sociedade no contexto em que ele se desenvolve. Deve-se observar que valores não devem corresponder a julgamentos pelo pesquisador. "Justamente o conhecimento do processo não-planejado, cego e dispendioso do desenvolvimento da sociedade coloca no centro das atenções o problema de se os seres humanos estão em condições de encontrar caminhos para o progresso que não custem tantas vidas." (ELIAS, 2006, p. 230). Por fim, a proposta de Elias consiste exatamente em incitar a pesquisa dos processos não-planejados.

Embora a educação consista na elaboração planejada do que se vai ensinar e como isso deve ocorrer, ela é uma figuração social resultante. Então, como os mais diversos espaços sociais de interação, ensinar e aprender estão totalmente envoltos de processos criados na sociedade na qual se encontra inserida. A identidade nacional constitui uma construção elaborada pelas pessoas ao longo da história daquele povo. As ideias acerca da formação nacional e de como ela deve se perpetuar por meio da educação não se originam no ambiente escolar, portanto. 
Responder à questão sobre os problemas decorrentes de resultados não-planejados a partir de ações planejadas contribui com as ciências humanas no sentido de parar de justificar de maneira pouco científica dados acontecimentos. Assim, não é permitido na educação brasileira falar em várias religiões existentes, considerando-se a possibilidade de continuação da religião oficial, existente no Brasil colonial, apesar de relacionada ao ideal de civilidade pregado até os dias atuais.

\section{RESULTADOS E DISCUSSÃO}

Os boletins da CNMC e a BNCC trazem elementos educacionais para a afirmação de uma importância do ensino religioso no Brasil. Em 1984, como em 2017, o Ministério da Educação documenta sobre a forma de abordagem da religião nas salas de aula em todo o país. Apesar de mencionar na introdução uma legislação que preserva a ausência de proselitismo, o discurso verificado no texto incorre no contrário.

Com uma redação que procura considerar a diversidade religiosa do país, os documentos vão defendendo a religiosidade como "parte integrante do substrato cultural da humanidade" (BRASIL, 2017). Nesse sentido, o discurso oficial do Ministério da Educação considera a religião como uma das bases para a formação do indivíduo. Com o propósito de tornar o conhecimento religioso para o ensino fundamental da educação básica algo científico, reforça a afirmação da identidade cultural e, por consequência, nacional, a partir da afirmação de tradições religiosas dos povos.

Em 1984, vários estados da federação estavam organizando encontros de EMC (Amapá, São Paulo, Pernambuco, Minas Gerais e Paraná). Cada estado possuía uma representação da CNMC e sua própria Comissão estadual (COMOCI), controlada de perto pelo governo federal. Na análise dos boletins verifica-se que algumas delas relacionavam assuntos cívicos a religiosos, sendo motivo de chamada de atenção pela instituição central. Apesar disso, os boletins foram elaborados com o objetivo de reforçar a comunidade escolar e acadêmica "na luta contra a onda iconoclasta" (BRASIL, 1984, n. 1, p. 1).

Após 15 anos, a CNMC comemora sua existência com dois boletins que trazem os feitos e ações ainda esperadas pela EMC em todo o Brasil. Assim, a disciplina, criada na educação formal brasileira em 1969 e extinta em 1993, deveria ensinar "os corretos valores de tal forma que os estudantes se tornem cidadãos úteis, capazes de sua auto-realização, assim voltados sempre para o bem comum” (BRASIL, 1984, n. 2, p. 1). A função da CNMC era fiscalizar se isso realmente ocorria nas salas de aula em todo o país, apesar de não ser identificado diretamente pelos docentes em alguns casos (GONDIM; COSTA, 2019).

Um dos temas tratados pelos boletins, cujo título era EMC em foco, trazia textos de sujeitos importantes para a disciplina em âmbito nacional. No primeiro número, o texto de José Barreto Filho ${ }^{2}$, sob o título Orientação e programação de EMC em todos os graus como disciplina e atividade, traz conceitos que serão observados posteriormente na BNCC, área de ensino religioso. A educação como espaço para a transmissão de valores básicos na convivência social e necessidade de harmonia. Considera elementos morais e cívicos como características de tradição e cultura, baseadas em "valores espirituais" (BRASIL, 1984, n. 1, p. 5). Tratados na condição de fundamentos axiológicos, consideram a importância de uma educação que aborda a religiosidade para a formação humana e cidadã.

Como resultado, deve-se ter a "criação de hábitos que levem o homem à realização desses valores em sua existência concreta, estimulando-o a agir segundo as coordenadas de seu desenvolvimento individual e o bem da comunidade" (BRASIL, 1984, n. 1, p. 5). A EMC deveria promover mudanças comportamentais para além dos conteúdos ensinados e desenvolvidos na disciplina. Na BNCC de 2017, o ensino religioso consta como uma das cinco áreas do conhecimento para o ensino fundamental, além de ser considerado um componente curricular. Desse modo, constitui como um campo próprio na formação educativa do indivíduo durante o período mais longo da educação básica, considerando como educação a importância da percepção das alteridades por meio da dialógica. Identidades e alteridades são tema de unidade no ER, numa associação dentre o ser individual e coletivo, considerando o papel simbólico da formação do sujeito. É possível encontrar relação de sentido entre a EMC e o ER, principalmente no aspecto que condiciona individualidade à coletividade e à identidade.

0 texto do EMC em foco, número 2, escrito por Girão Barroso ${ }^{3}$, tem por título Data comemorativa da EMC. Barroso comemora os quinze anos de criação da CNMC, lembrando seu papel na "formação espiritual da juventude" (BRASIL, 1984, n. 2, p. 8) em contraponto ao perigo vivido pela sociedade de se tornar

\footnotetext{
${ }^{2}$ Foi membro do Conselho Federal de Educação (CFE) e professor catedrático da Pontifícia Universidade Católica do Rio de Janeiro (PUC-RJ).

3 Professor universitário e Conselheiro da CNMC.
} 
"permissiva e hedonista" (BRASIL, 1984, n. 2, p. 9). Assim como o ER, a EMC apresentava-se como disciplina necessária e requerida para manutenção das tradições sociais por meio da educação formal. Ambos os conhecimentos procuram tratar o espaço escolar como sendo para ações práticas do que deveria ocorrer na sociedade.

Dentre as competências citadas como específicas do ER para o ensino fundamental, encontra-se menção ao conhecimento de "aspectos estruturantes das tradições/movimentos religiosos e filosofias de vida" (BRASIL, 2017, p. 437). No campo das tradições, há ainda a competência em "analisar as relações entre as tradições religiosas e os campos da cultura (...)" (BRASIL, 2017, p. 437). Na cultura brasileira, ao tratar de "tradições", o conceito é bastante fluido e parte para a relativização por meio de um discurso no qual o passado brasileiro apresenta grupos culturais diversos. Nessa diversidade, recorre-se à mistura apresentada e defendida pela literatura, significando "o misturado é completo; o puro é incompleto, é pobre" (FIORIN, 2009, p. 120). Brancos, negros e índios produziram a completude da identidade nacional; mas no campo da cultura, principalmente religiosa, a predominante não decorre dessa mesma mistura.

Assim como a EMC objetivava a mudança de comportamento prático do indivíduo, o ER também. Um exemplo é a competência a ser desenvolvida na qual o estudante deve procurar se posicionar em episódios de intolerância religiosa. Apesar do combate à intolerância, apresenta-se como uma habilidade a ser desenvolvida na formação do ER a identificação dos símbolos presentes nos espaços de convivência. Outra habilidade apresentada é a caracterização de "práticas celebrativas (cerimônias, orações, festividades, peregrinações, entre outras) de diferentes tradições religiosas" (BRASIL, 2017, p. 447). Ambas as habilidades a serem desenvolvidas na formação correspondem à preponderância na cultura brasileira do cristianismo, tido em muitos discursos como religião universal brasileira. Os espaços públicos foram ao longo da história proibidos de demonstrar a afirmação discursiva da "mistura" religiosa que constituiu o Brasil.

As habilidades anteriormente descritas devem ser desenvolvidas nas crianças até o 3oo ou seja, há um direcionamento de como a criança deve entender a religiosidade. A manutenção das tradições religiosas encontra continuidade em seu discurso de identidade nacional com a existência do ER, outrora outorgado à EMC. Embora as disciplinas tenham sido criadas com o intuito tácito de manter a identidade nacional por meio da continuidade das tradições culturais e valores morais pertencentes à sociedade brasileira, o discurso a elas atribuído era o de ensinar a diversidade do país. Esse objetivo encontra-se inserido na educação formal brasileira desde o princípio da instituição do processo deliberado de ensino e aprendizagem por meio da instituição de escolas pelo estado brasileiro.

\section{CONSIDERAÇÕES FINAIS}

Embora aparentemente constituindo concepções distintas, a EMC, existente até 1993, e o ER, área de conhecimento do ensino fundamental incluído na BNCC de 2017, trazem ideias que se assemelham no sentido de elaborar um conceito de identidade nacional no Brasil. Nos documentos da CNMC, bem como na BNCC sobre o ER, percebe-se o esforço em tornar científico e neutro o ensino das disciplinas, embora a EMC na época fosse obrigatória em todos os níveis e modalidades de ensino enquanto o ER é considerado de matrícula facultativa, apesar de constar na grade curricular de horário do $1^{\text {o }}$ ao $9^{\mathrm{o}}$ ano do ensino fundamental.

Como resultado "não planejado", vê-se que na afirmação de ideias consideradas de caráter moral ou religioso o acontecimento da interdição. A retomada da democracia suscitou debates cujo resultado configura na compreensão da identidade nacional brasileira. A CF de 1988 não menciona a obrigatoriedade ou mesmo existência da EMC, mas atesta a obrigatoriedade de ER nos horários normais do ensino fundamental. Sai EMC, permanece ER.

A identidade nacional não é disciplina específica a ser ensinada e aprendida em escolas de nenhuma civilização, mas perpassa pela compreensão de assuntos os mais diversos e pode se constituir como elemento base para algumas delas. Não se pode afirmar, objetivamente, que o ER deve ser a área do conhecimento cuja essência seja a formação do indivíduo para a compreensão da identidade nacional. No entanto, considerar religião algo com a importância para se conferir uma área da educação e um componente curricular a ser desenvolvido ao longo de 9 anos da formação básica do ensino é para se problematizar a seu respeito.

O ER ocupa o espaço deixado pela EMC e nos dois casos suscitam mais questionamentos do que certezas pela necessidade de sua permanência na educação formal. No entanto, assim como a EMC, o ER justifica-se cientificamente por um motivo muito mais subjetivo e emocional. A EMC e o ER encontram sua razão nas 
escolas por meio da afirmação de uma identidade nacional pertencente à sociedade e que deve ser mantida nas salas de aula, a tradição do povo brasileiro. Os valores morais e cívicos, na EMC, bem como a compreensão, valorização e respeito às manifestações religiosas, no ER, traduzem a manutenção de um sistema de dominação não pela exclusão explícita, mas por uma mistura.

A interdição finda por ocorrer na educação, tanto na EMC quanto no ER pela afirmação da identidade nacional brasileira como fruto de valores oriundos de diversos povos. Já identificado por Fiorin (2009) na literatura brasileira, deve ser objeto de questionamento e pesquisa também no campo da educação formal. Esse artigo visou suscitar algumas aproximações discursivas entre disciplinas identificadas como elaboradas e mantidas principalmente com o objetivo de manutenção de uma identidade nacional cujo enfoque é essencialmente religioso.

Analisar os documentos produzidos por instituições ligadas ao Ministério da Educação configura procurar entender o discurso oficial conferido às disciplinas na educação formal. Ao constatar o objetivo da EMC em manter os valores tradicionais da nacionalidade brasileira, aproxima-se ao discurso encontrado na organização do ER, tanto nas competências quanto habilidades a serem desenvolvidas pelo estudante. 0 resultado é a permanência de uma afirmação no espaço da educação formal no qual o processo não planejado de unicidade religiosa, assim se torna, por meio da interdição.

\section{REFERÊNCIAS}

[1] BRASIL. Lei n.o 9.475, de 22 de julho de 1997. Dá nova redação ao art. 33 da Lei no 9.394, de 20 de dezembro de 1996, que estabelece as diretrizes e bases da educação nacional. Diário Oficial da União, Brasília, DF, 22 jul. 1997. Disponível em: <

http://www.planalto.gov.br/ccivil_03/leis/L9475.htm\#: :text=\%22Art.,vedadas\%20quaisquer\%20formas\%20de $\% 2$ 0proselitismo.>. Acesso em 11 jul. 2020.

[2] BRASIL. Ministério da Educação e Cultura. Comissão Nacional de Moral e Civismo. Boletim Informativo da Comissão Nacional de Moral e Civismo. V. 1. N. 1. Rio de Janeiro: Comissão Nacional de Moral e Civismo, 1984.

[3] BRASIL. Ministério da Educação e Cultura. Comissão Nacional de Moral e Civismo. Boletim Informativo da Comissão Nacional de Moral e Civismo. V. 1. N. 2. Rio de Janeiro: Comissão Nacional de Moral e Civismo, 1984.

[4] BRASIL. Ministério da Educação. Secretaria de Educação Básica. A área de Ensino Religioso. In Base Nacional Comum Curricular. Brasília, DF, 2017. p. 435-459.

[5] ELIAS, Norbert. Para a fundamentação de uma teoria dos processos sociais. Escritos e ensaios: Estado, processo opinião pública. vol. 1. Rio de Janeiro:

[6] Jorge Zahar Ed., 2006.

[7] FIORIN, José Luiz. A construção da identidade nacional brasileira. Bakhtiniana, São Paulo, V. 1, N. 1, p. 115126, $1^{\circ}$ sem. 2009. Disponível em: <https://revistas.pucsp.br/bakhtiniana/article/view/3002/1933>. Acesso em: 13 jul. 2020.

[8] GONDIM, Amanda Marques de Carvalho; COSTA, Alexsandro Barbosa. A Educação Moral e Cívica no Brasil durante a ditadura: poder e resistências. Foro de Educación, V. 17, N. 26, 2019, p. 153-173. Disponível em <http://dx.doi.org/10.14516/fde.597>. Acesso em: 13 jul. 2020.

[9] GONDIM, Amanda Marques de Carvalho. A pátria nasceu aqui: o discurso das Batalhas dos Guararapes: a educação brasileira nas décadas de 1960 e 1970. Saarbrücken: OmniScriptum Marketing DEU GmbH, 2017.

[10] SILVA, Kalina Vanderlei; SILVA, Maciel Henrique. IDENTIDADE. In: DICIONÁRIO de conceitos históricos. São Paulo: Contexto, 2006. p. 202-205.

[11] SOUZA, Jessé. A elite do atraso: da escravidão à lava jato. Rio de Janeiro: Leya, 2017.

[12] UNESCO. Educação um tesouro a descobrir: relatório para a UNESCO da Comissão Internacional sobre Educação para o século XXI. São Paulo: Cortez, 1998. 


\section{Capítulo 8}

Políticas Públicas e sua importância na garantia de uma educação de qualidade

\section{Manuela Gomes Maués}

Rosivanda Cunha Moraes

Resumo: 0 presente trabalho, com o intuito de mostrar a importância da educação para a formação cidadã, desenvolvimento do processo de ensino aprendizagem e progresso da sociedade, realizou uma pesquisa de cunho bibliográfico buscando, através de livros, artigos e documentos digitais, levantar conhecimentos e explicar o objeto estudado, pautando-se nas abordagens teóricas propostas por Bulos (2009); Kant (1996); Oliveira (2010); Quadros (2008); Bencini (2006); Saviani (2010); Azevedo (2007); Furghestti (2012); BRASIL (1996); Chiara, Kaimen (2008); que destacam a importância de uma educação de qualidade, e os benefícios que a garantia desta traz para os alunos, professores, sociedade e para o país. Desse modo, as Políticas Públicas são de suma importância para a garantia de uma educação de qualidade para todos, pois contribui significativamente para com a evolução do processo de ensino aprendizagem dos alunos, minimizando os índices de evasão, de reprovação e favorecendo o progresso do país.

Palavras-chave: Educação de qualidade, Políticas Públicas, Ensino Aprendizagem. 


\section{INTRODUÇÃO}

As políticas públicas são importantes direitos constitucionais que são oferecidos e portanto devem ser garantidos a todos os cidadãos. Por isso, sabendo da relevância destes direitos para o desenvolvimento da sociedade, o assunto está presente como pauta em muitas discussões. No entanto, neste artigo abordaremos mais notadamente as políticas públicas educacionais, visando mostrar os reflexos desta na educação brasileira. Com o intuito de garantir uma escola pública para todos e com educação de qualidade, estas políticas são lançadas, sendo assim, para alcançar estes ideais faz-se necessário seguir os objetivos propostos na Constituição Federal a qual preleciona em seu artigo 205, que:

Art. 205: A educação, direito de todos e dever do Estado e da família, será promovida e incentivada com a colaboração da sociedade, visando ao pleno desenvolvimento de pessoas, seu preparo para o exercício da cidadania e sua qualificação para o trabalho (BULOS, 2009).

Desse modo, é evidente que a educação é uma política pública que deve ser ofertada e garantida a todos os cidadãos, mas tal política ainda apresenta várias lacunas, porém já se modificou em vários aspectos, uma vez que, outrora no período ditatorial o país foi vítima de uma grande crise econômica e tal política passou a ser vista como mera formadora de mão de obra, que serviria apenas para fortalecer o sistema capitalista brasileiro. Agravaram-se as desigualdades sociais, o acesso à educação tornava-se cada vez mais restrito, pois somente os alunos com maior poder aquisitivo, isto é, somente as classes dominantes possuíam o direito de desfrutar de uma educação de qualidade, tinham o acesso ao ensino superior facilitado, e consequentemente dirigiam e integravam grandes cargos no sistema capitalista.

Por outro lado, para os alunos que possuíam menor poder aquisitivo ficavam apenas os cursos técnicos profissionalizantes, que auxiliavam grande parte da massa assalariada e os tornava subalternos da classe dominante. Além disso, durante a ditadura a educação foi vítima de fortes perseguições e censuras contra qualquer ato contrário aos ideais capitalistas, ou seja, os ditatores objetivando aniquilar toda forma de ameaça contra a monarquia, buscavam punir, reprimir qualquer indivíduo que fosse de encontro as suas ordens. No entanto, atualmente, a educação não está na sua melhor fase, porém se comparada a outrora, já avançou significativamente no que diz respeito a formação de professores, infraestrutura, inclusão de recursos tecnológicos, material didático, educação acessível para grande parte da população, aniquilação das censuras e represálias, entre outros.

Nessa perspectiva, fica claro que a educação brasileira passou sim por um cruel e penoso período de problemas, mas sofreu mudanças que proporcionaram uma promissora melhora na educação, porém não foram suficientes o bastante para sanar as dificuldades da garantia de uma educação de qualidade para todos. Pois, ainda há escolas com infraestruturas precárias; salas super lotadas; falta de carteiras, livros e transporte escolar; ausência de recursos tecnológicos; falta de cursos profissionalizantes e professores especializados; entre outros. Nesse sentido, não basta apenas oferecer leis, faz-se necessário cumpri-las, para que haja a efetivação de uma educação para todos e de qualidade. Seguindo essa ideia, KANT (1996, p.19) afirma que:

"A educação é uma arte, cuja prática necessita ser aperfeiçoada por várias gerações. Cada geração, de posse dos conhecimentos das gerações precedentes, está melhor aparelhada para exercer uma educação que desenvolva todas as disposições naturais na justa proporção e de conformidade com a finalidade daquelas, e, assim guie toda a humana espécie a seu destino" (KANT, 1996, p.19).

Sabendo que a educação é uma arte, que deve ser aperfeiçoada, torna-se necessário a valorização desta política por parte do estado, haja visto que, compete a ele investir e articular ações que proporcionem o desenvolvimento da mesma. Todavia, em um país que não reconhece a educação como prioridade, tais ações não são desenvolvidas da maneira que deseja-se, pois falta investimentos e como se não bastasse há a criação de vários projetos, que não são valorizados pelos entes federados e por isso não são concretizados, o que dificulta a garantia de uma educação de qualidade e ocasiona mazelas que prejudicam significativamente o avanço do país. Sendo assim, é evidente que a educação é uma importante ferramenta para o desenvolvimento do cidadão, por isso neste trabalho, objetivando mostrar a magnitude da educação para o progresso da sociedade, faz-se necessário discutir a educação e o quão a falta de investimentos nesta política prejudica o desenvolvimento de um ensino de qualidade. 


\section{DESENVOLVIMENTO}

As políticas públicas educacionais são importantes direitos que devem ser garantidos a todos os indivíduos. Porém, antes de entendermos do que se trata as políticas educacionais, faz-se necessário compreendermos o que são as políticas públicas, que de acordo com a etimologia da palavra refere-se ao desenvolvimento a partir do trabalho do Estado junto as decisões do povo, OLIVEIRA (2010) diz que:

"Se "políticas públicas" é tudo aquilo que um governo faz ou deixa de fazer, políticas públicas educacionais é tudo aquilo que um governo faz ou deixa de fazer em educação. Porém, educação é um conceito muito amplo para se tratar das políticas educacionais. Isso quer dizer que políticas educacionais é um foco mais específico do tratamento da educação, que em geral se aplica às questões escolares. Em outras palavras, pode-se dizer que políticas públicas educacionais dizem respeito à educação escolar" OLIVEIRA (2010).

Assim, fica claro que as políticas públicas educacionais é tudo o que é feito ou não pelo governo na educação. É importante destacar, também, que as Políticas Públicas Educacionais, não estão relacionadas apenas com o acesso em massa das crianças e adolescentes nas escolas públicas, mas também com a construção e o desenvolvimento da sociedade que origina-se em decorrência desta educação. Logo, as Políticas Públicas Educacionais influenciam de maneira significativa a vida de cada indivíduo.

Sabendo da importância das políticas públicas para o desenvolvimento dos cidadãos, e portanto da sociedade, apenas garantir estas políticas não é suficiente para conceder uma educação de qualidade para todos, uma vez que, existem outros problemas relacionados as políticas públicas que devem ser tratados. Como por exemplo: a fome, as drogas, a violência, entre outros, tais problemas, estão relacionados com o baixo desenvolvimento na educação pública, e segundo Quadros (2008) estão presentes no cotidiano das escolas de todo o Brasil. Além deste, tem-se também:

Crianças de 5a série que não sabem ler nem escrever, salários baixos para todos os profissionais da escola, equipes desestimuladas, famílias desinteressadas pelo que acontece com seus filhos nas salas de aula, qualidade que deixa a desejar, professores que fingem que ensinam e alunos que fingem que aprendem. 0 quadro da Educação brasileira (sobretudo a pública) está cada vez mais desanimador [...] (BENCINI, 2006).

Sendo assim, é evidente o desprezo das autoridades federadas para com a educação brasileira, sobretudo a educação pública, e isso faz com que a qualidade desta política fique cada vez pior, tanto de forma estrutural quanto no desenvolvimento dos alunos no processo de ensino aprendizagem. As Políticas Públicas Educacionais estão diretamente ligadas com a qualidade da educação e o quão está é importante para a formação da cidadania. São grandes as lutas para conseguir uma escola cidadã no Brasil e estão cercadas por uma história com fortes impactos e desapontamentos, como afirma Azevedo (2007, p.77):

Ao evidenciar um conjunto de concepções, práticas e estruturas inovadoras, a experiência da escola cidadã aponta possibilidades de uma educação com qualidade social, não redutora à dinâmica mercantil. 0 desenvolvimento de uma cultura participativa, de uma inquietação pedagógica com a não-aprendizagem, da busca dosaportes teóricos da ciência da educação, legitima a idéia de que a não-aprendizagem é uma disfunção da escola e que a reprovação e a evasão são mecanismos de exclusão daqueles setores sociais que mais necessitam da escola pública. Isso levou à convicção da necessidade de reinventar a escola, de redesenhá-la de acordo com novas concepções. Os avanços na formação em serviço evidenciaram aos educadores que a estrutura convencional da escola está direcionada para transmissão, para o treinamento e para a repetição, tendendo a neutralizar as novas proposições pedagógicas, no máximo transformando-as em modismos fugazes. Por isso, embora essenciais, não bastam apenas mudanças metodológicas, novidades teóricas, a adesão aos princípios de uma escola inclusiva, democrática, com práticas avaliativas voltadas ao sucesso do educando, é indispensável ainda a superação da estrutura taylorista-fordista, redefinindo os espaços, os tempos e os modelos de trabalho escolar. 
De acordo com Azevedo, estes impactos e desencantos na educação brasileira dá a ela o status de baixa qualidade. Nessa perspectiva, faz-se necessário entender o quanto necessita-se de uma educação de qualidade, mas tal objetivo, de acordo com Saviani (2010) só pode ser alcançado quando a escola cumpre seu papel social e educacional.

A valorização da educação é de suma importância para a construção de uma sociedade mais justa, e cidadã, por este motivo torna-se necessário debater a respeito de melhorias na qualidade da educação, com o decorrer do tempo tal pauta está presente e muitas discussões de forma mais intensa, com isso tem-se que:

A QUALIDADE do ensino tem sido foco de discussão intensa, especialmente na educação pública. Educadores, dirigentes políticos, mídia e, nos últimos tempos, economistas, empresários, consultores empresariais e técnicos em planejamento têm ocupado boa parte do espaço dos educadores, emitindo receitas, soluções técnicas e, não raro, sugerindo a incompetência dos educadores para produzir soluções que empolguem a qualificação do ensino. Essa invasão de profissionais não identificados ou não envolvidos com as atividades do campo educacional merece uma reflexão. Não se trata aqui de preconizar o monopólio da discussão da educação aos educadores, mas de registrar a intensa penetração ideológica das análises, dos procedimentos e das receitas tecnocráticas à educação (AZEVEDO, 2007).

A qualidade no ensino, sobretudo nas escolas da rede pública, deve ser construída e sustentada por programas e projetos, que objetivem resgatar a qualidade da educação pública e promover a efetivação de um nível educacional mais satisfatório, formando cidadãos críticos capazes de distinguir seus direitos e deveres. No entanto, tais objetivos só serão alcançados quando a educação deixar de ser vista como mera formadora de mão de obra e fornecedora de conhecimentos prontos, pois um ensino de qualidade deve buscar de acordo com Furghestti (2012) transmitir valores éticos, morais e cidadãos, que sejam construtores de novos conhecimentos e de uma sociedade melhor.

É perceptível que a qualidade no ensino público é necessário para o desenvolvimento do cidadão, qualificação para o trabalho, e para a evolução do processo de ensino aprendizagem dos estudantes, para isso é importante que haja a parceria das instituições de ensino, dos pais e também do estado, pois de acordo com a Lei de Diretrizes e Bases da Educação Nacional - LDB (Lei n 9394/96) em seu artigo $2^{\circ}$ :

Art. 2ํ. A educação, dever da família e do Estado, inspirada nos princípios de liberdade e nos ideais de solidariedade humana, tem por finalidade o pleno desenvolvimento do educando, seu preparo para o exercício da cidadania e sua qualificação para o trabalho (BRASIL, 1996).

A educação é um dever da família e do estado, no entanto, ainda há falhas no cumprimento deste dever, dado que o estado por não priorizar a educação não investe da maneira adequada nesta política e isso dificulta o oferecimento de uma educação de qualidade para todos os cidadãos brasileiros e também não facilita a realização do papel da família no processo de ensino aprendizagem do estudante. Esta falta de investimentos na educação ocasiona problemas, como: super lotação das salas, escolas com infraestruturas precárias, falta de carteiras, calor exacerbado nas salas, falta de materiais didáticos, falta de transportes, entre outros; tais fatores contribuem de forma negativa no âmbito escolar, pois de acordo com a Secretaria de Estado da Educação (SEED), a falta do transporte escolar acarreta a evasão dos alunos, tornando a taxa de abandono na região Norte superior à média nacional e além do mais, provocam o aumento no índice de reprovação.

Outro fator que contribui para não efetivação de uma educação de qualidade é a desvalorização do professor, pois este mesmo sendo peça chave para o processo de aprendizagem do aluno ainda não é valorizado da maneira que deveria, dado que, enfrenta diariamente o rebaixamento salarial, não desfruta de recursos que possibilitem a formação continuada, são submetidos a precárias situações de trabalho, não tendo condições adequadas para sua atuação em sala. Os fatos elencados, deixam o profissional da educação insatisfeito com suas condições de trabalho o que ocasiona um baixo interesse dos futuros docentes pela profissão. 
Sendo assim, fica claro que a educação é uma importantíssima ferramenta para o desenvolvimento do cidadão, da sociedade e consequentemente do país, mas tal avanço só será possível se houver o investimento adequado por parte dos entes federados nesta política. Por isso, faz-se necessário investir em educação de modo que esta não seja apenas mera formadora de mão de obra, mas sim a melhor ferramenta para a formação da cidadania, desenvolvimento do processo de ensino aprendizagem e avanço do país. Ademais, por a educação ser um dever da família e do estado a parceria entre estes dois membros torna-se essencial para o progresso do alunado no andamento do ensino aprendizado.

\section{METODOLOGIA}

0 presente trabalho, com o intuito de mostrar a importância da garantia de uma educação de qualidade para o desenvolvimento da cidadania, melhoria do processo de ensino aprendizagem e progresso do país, realizou uma pesquisa bibliográfica a fim de apresentar argumentos que fortaleçam estes ideais e sirvam como respaldo e incentivo para as lutas em prol de um ensino qualitativo e não quantitativo. A pesquisa de cunho bibliográfico buscando levantar conhecimentos e explicar o objeto estudado, foi elaborada a partir do uso de livros, artigos e documentos digitais, que tratavam sobre esta temática. Como afirma Chiara:

A pesquisa bibliográfica é então feita com o intuito de levantar um conhecimento disponível, sobre teorias, a fim de analisar, produzir ou explicar um objeto sendo investigado. A pesquisa bibliográfica visa então analisar as principais teorias de um tema, e pode ser realizada com diferentes finalidades. (CHIARA, KAIMEN, et al.,2008).

Nesse sentido, para desenvolver este estudo nos pautamos nas abordagens teóricas propostas por Bulos (2009); Kant (1996); Oliveira (2010); Quadros (2008); Bencini (2006); Saviani (2010); Azevedo (2007); Furghestti (2012); BRASIL (1996); Chiara, Kaimen (2008); que destacam a importância de uma educação de qualidade, e os benefícios que a garantia desta traz para os alunos, professores, sociedade e portanto para o país. Uma vez que, contribui positivamente para o processo de ensino aprendizagem do alunado, o tornando um cidadão crítico e capaz de realizar atividades trabalhistas de qualidade.

\section{CONSIDERAÇÕES FINAIS}

Por fim, em decorrência dos fatos mencionados é evidente que as Políticas Públicas Educacionais são de suma importância no que se refere a tornar a educação pública mais qualitativa, e formar cidadãos. Tal política durante o período militar, por ser vista apenas como mera formadora de mão de obra, passou por um terrível momento de represálias e infortúnios, que impediam o processo do crescimento intelectual e escolar. As represálias foram erradicadas, porém o descaso perdura, pois ainda existe a falta de investimentos no âmbito educacional, haja visto que, ainda há escolas com péssimas estruturas; com super lotação de salas, carteiras danificadas, com falta de professores e muitos outros problemas.

Então, neste artigo com o objetivo de apresentar os reflexos que a falta de Políticas Públicas ocasionam na educação analisamos por meio de livros, artigos, e documentos digitais dados que fortaleçam a temática tratada nesta indagação.

Enfim, cumprir os direitos constitucionais, investir na educação, mais notadamente da rede pública, e garantir a qualidade da mesma a todos os indivíduos é de grande valia, pois contribui significativamente para com a evolução do processo de ensino aprendizagem dos alunos, minimizando os índices de evasão, de reprovação e favorecendo o progresso do país.

\section{AGRADECIMENTOS}

Agradecemos a Deus pelo dom da vida, e a sabedoria a nós concedida, que foi essencial para a escrita desta pesquisa. Agradecemos a todos os professores que contribuíram e contribuem de maneira significativa para a nossa formação enquanto futuros docentes. Somos gratas a Universidade Estadual do Pará (UEPA) que nos deu a oportunidade de cursar a Licenciatura Plena em Matemática nesta renomada instituição. Um agradecimento especial a nossos pais que sempre nos incentivam e não medem esforços para nos ajudar a alcançar nossos ideais. Reconhecemos também a importância da realização do evento no que se refere a ampliação de nossos conhecimentos, e espaço adequado para troca de ideias e exposição das nossas opiniões. Enfim, agradecemos profundamente as todos os que contribuíram direta ou indiretamente para a realização deste trabalho. 


\section{REFERÊNCIAS}

[1] AZEVEDO, José Clovis de. Educação pública: o desafio da qualidade. Estud. av. v.21. n.60. São Paulo. May/Aug. 2007.

[2] BENCINI, Roberta; MORAES, Trajano de; MINAMI, Thiago. 0 desafio da qualidade não dá mais para esperar: ou o Brasil coloca a Educação no topo das prioridades ou estará condenado ao subdesenvolvimento. A boa notícia é que a situação tem jeito se a sociedade agir já. Nova Escola. Ano XXI. N.1996. Out. de 2006.

[3] BRASIL. Lei no 9.394, de 20 de dezembro de 1996. Disponível em: <http://portal.mec.gov.br/seed/arquivos/pdf/tvescola/leis/lein9394.pdf>. Acesso em: 27 de agosto de 2020.

[4] BULOS, Uadi Lammêgo. Constituição federal anotada. 9. ed. rev. e atual. até a EC n.57/2008. São Paulo: Saraiva, 2009.

[5] CHIARA, I. D. et al. Normas de documentação aplicadas à área de Saúde. Rio de Janeiro: Editora E-papers, 2008.

[6] FURGHESTTI, Mara Luciane da Silva; GRECO, Maria Terêsa Cabral; CARDoso, Rosinete Costa Fernandes. Ensino fundamental de nove anos: os impactos das políticas públicas para a alfabetização com letramento. IX ANPED Sul Seminário de Pesquisa em Educação da Região Sul. 2012.

[7] Kant, Immanuel. Sobre a Pedagogia. Tradução: Francisco Cock Fontanella. Piracicaba, SP: Ed. Unimep, 2006.

[8] OLIVEIRA, Adão Francisco de. Políticas públicas educacionais: conceito e contextualização numa perspectiva didática. In: OLIVEIRA, Adão Francisco de. Fronteiras da educação: tecnologias e políticas. Goiânia-Goiás: PUC Goiás, 2010.

[9] SAVIANI, Demerval. História das ideais pedagógicas no Brasil. Campinas-SP: Autores Associados, 2010. 


\section{Capítulo 9}

Percursos das políticas públicas da conservação do patrimônio tangível no Brasil

\section{Karen Velleda Caldas \\ Flávio Sacco dos Anjos \\ Javier Bueno Vargas \\ Micheli Martins Afonso}

Resumo: 0 estudo que aqui se apresenta analisou brevemente as normas e leis que regem o campo patrimonial no Brasil, em especial, o patrimônio tangível e a área de Conservação. Buscou-se centrar o olhar nos bens culturais móveis e na relação dessas normas com a profissão do conservador-restaurador. A partir de uma revisão bibliográfica e de dados colhidos em sítios oficiais do governo brasileiro, em teses doutorais, artigos científicos e publicações sobre as normas e leis que regem o campo patrimonial, logrou-se conhecer algumas das particularidades das normas de acautelamento do patrimônio material, singularidades estas que agem como coadjuvantes na compreensão da dinâmica de desenvolvimento da área e da profissão do conservador-restaurador.

Palavras-chave: Conservador-Restaurador; Conservação; Patrimônio Cultural. 


\section{INTRODUÇÃO}

O campo do patrimônio cultural há que ser visto hoje como uma arena de disputas, palco onde a área de Conservação ${ }^{4}$ está inserida. No Brasil, a Conservação pode ser considerada jovem se comparada ao contexto europeu. Todavia, estudos como o de Castro (2013) apontam que, como atividade laboral, surgiu no cenário do serviço público muito antes das políticas nacionais de preservação do patrimônio advindas da criação do SPHAN (Serviço do Patrimônio Histórico e Artístico Nacional) 5 . Tal como ocorreu no restante do Ocidente, a Conservação percorreu um trajeto que se modificou ao longo do tempo, especialmente nos últimos cem anos. Chegamos ao século XXI com uma área de atuação significativamente ampliada uma vez que inclui, além dos bens tangíveis - móveis e imóveis, os de natureza imaterial, traduzidos no conceito de "bens culturais". Não obstante, trata-se de uma esfera complexa que requer tanto especialização profissional, quanto capacidade de interlocução entre diversas áreas de conhecimento, isto é, exige que o trabalho seja articulado interdisciplinarmente. De modo bastante resumido, pode-se inferir que o manejo dos bens culturais particularmente quando tratamos da cultura material, exige na contemporaneidade uma atuação pautada pelo domínio técnico e científico, mas, sobretudo, que seja ela orientada por fatores humanísticos, onde os atores sociais devem ser os protagonistas.

O presente artigo é parte de uma pesquisa mais ampla envolvendo o estudo sobre as concepções subjacentes à práxis da Conservação do patrimônio material nos âmbitos brasileiro e espanhol. Nesse contexto, a reflexão aqui apresentada explora um recorte da pesquisa supracitada, centrando o foco no sentido de analisar a legislação relativa ao cenário da preservação no Brasil, com ênfase nos bens culturais móveis, e sua relação com a profissão do conservador-restaurador.

Neste artigo abordam-se alguns aspectos alusivos ao âmbito brasileiro da investigação, tendo como fonte tanto uma pesquisa bibliográfica, quanto uma busca em sítios oficiais do governo brasileiro, em artigos científicos e outras publicações sobre as normas e leis que regem o campo patrimonial. As reflexões tomaram como referência autores como Carlan e Funari (2008), Paiva e Miranda (2011), Mattar (2012), dentre outros. Nessa imersão revelam-se as particularidades do âmbito brasileiro no que tange às normas e leis ligadas direta ou indiretamente à preservação do patrimônio tangível, colaborando também na compreensão da dinâmica de desenvolvimento da área de Conservação e da profissão do conservadorrestaurador no Brasil. Cumpre destacar que, embora o ponto focal deste estudo seja o patrimônio material, a evolução do sentido de preservação patrimonial não pode ser compreendida isoladamente. Desse modo, se analisa a questão do patrimônio de modo abrangente, visando percorrer a legislação de maneira ampla, não obstante a ênfase esteja posta sobre os bens culturais móveis. Sobre essa base nosso olhar buscou responder a uma grande questão, qual seja, como evoluiu esse campo do conhecimento no Brasil? Quais foram os grandes marcos que nortearam essa atividade profissional ao longo do tempo?

\section{CONTEXTUALIZAÇÃO HISTÓRICA SOBRE A QUESTÃO DO PATRIMÔNIO CULTURAL NO BRASIL}

Falar de patrimônio e de sua salvaguarda vai muito além de apontar sua legislação ou políticas de proteção normatizadas (FONSECA, 2005). No entanto, neste estudo não se pretende abordar com profundidade o complexo processo de tensões e conflitos que envolvem a produção e a apropriação do campo patrimonial. Aqui pretende-se, tão somente, refletir sobre as principais normas e leis ${ }^{6}$ relativas à preservação do patrimônio no Brasil, com ênfase ao patrimônio material móvel, para, a partir desse levantamento, compreender melhor a dinâmica do desenvolvimento do campo disciplinar e o desenho da profissão do conservador-restaurador neste país.

\footnotetext{
4 Neste estudo, o termo é grafado com maiúscula quando se refere ao campo disciplinar ou ao conjunto abrangente de ações que incluem ações mais específicas - a conservação preventiva, a conservação curativa ou a restauração - descritas pelo ICOM-CC e traduzidas para o português pela ABRACOR (ABRACOR, 2010).

5 Atual IPHAN, Instituto do Patrimônio Histórico e Artístico Nacional.

${ }^{6}$ Apenas para registro e ainda que não tenham poder normativo, cumpre-nos apontar que as Cartas Patrimoniais documentos que resultam de reuniões nacionais e internacionais relativas ao tema e que demonstram a preocupação com o trato do patrimônio - foram importantes documentos norteadores para a criação de normas e leis redigidas a partir do Século XX.
} 
Inicialmente é oportuno mencionar que o tratamento jurídico do campo patrimonial no Brasil vem se modificando ao longo dos anos. As primeiras tentativas - inócuas por falta de respaldo jurídico - foram dirigidas ao patrimônio edificado, havendo surgido durante o governo provisório ${ }^{7}$ em 1933 através dos Decretos no 22.928, de 12 de julho de 1933 e o de no 24.735, de 14 de julho de 1934 (BOJANOSKI, 2012, 20; ANDRADE, 1987, 67). 0 primeiro deu status de Monumento Nacional para a cidade de Ouro Preto e o segundo declarou necessária a autorização do Museu Histórico Nacional, presidido à época por Gustavo Barroso, para quaisquer intervenções nos imóveis classificados como monumentos. Além disso, o decreto indicou a organização de um catálogo de objetos históricos e artísticos no âmbito do país.

O primeiro órgão da Administração Pública com vistas ao cuidado com o patrimônio brasileiro, foi a Inspetoria de Monumentos Nacionais, criada em 1934 (RODRIGUES E SERRES, 2012, 31). Entretanto, suas atribuições limitavam-se à inspeção dos monumentos e do comércio de arte com caráter histórico (CHUVA, $2005,44)$. A temática do patrimônio apareceu explicitamente pela primeira vez na Constituição de 1934.0 Art. 148 atribuiu à União, aos Estados e aos Municípios a proteção dos objetos de interesse histórico e o patrimônio artístico do país (BRASIL, 1934). Gustavo Capanema, que à época estava à frente do Ministério da Educação e Saúde (MES), articulou com Mário de Andrade o projeto de criação de um Serviço Nacional para a defesa do patrimônio, cuja concepção de patrimônio era extremamente avançada para a época (RODRIGUES E SERRES, 2012, 34).

Capanema liderava a corrente modernista e Barroso, ao contrário, inclinava-se ao conservadorismo e à reafirmação das tradições do Estado, dos militares e das oligarquias (MAGALHÃES, 2017, 237). 0 projeto de Capanema não avançou e sucumbiu em 1937 à criação do Serviço de Patrimônio Histórico e Artístico Nacional (SPHAN) ${ }^{8}$, sob a direção de Rodrigo de Melo Franco. Percebe-se, nessa polarização de interesses entre Barroso e Capanema, o campo de tensões e disputas que a preservação patrimonial representava no âmbito do Estado (CHUVA, 2005, 45).

Podemos dizer que a gênese da legislação específica sobre o patrimônio é construída, concretamente, durante o chamado Estado Novo (1937-1945). O regime político instaurado por Getúlio Vargas caracterizou-se pela tentativa de criação de uma identidade nacional sustentada, política e ideologicamente, em três pilares fundamentais ${ }^{9}$ : o turismo, a propaganda e o patrimônio (VIANNA, 2018). Pautava-se, sobretudo, na construção de um novo modelo de identidade nacional e na criação de uma imagem positiva do Brasil para o mundo. Nesse contexto, o projeto do novo Brasil de Getúlio Vargas contou com as elites intelectuais modernistas ${ }^{10}$ como atores influentes na criação das políticas públicas relativas ao patrimônio ${ }^{11}$ nacional.

A questão patrimonial havia sido ampliada na Constituição de $1937^{12}$ ao incluir, além dos monumentos históricos e artísticos - já referenciados na Constituição anterior - os monumentos naturais e as paisagens. No afã de regular o campo patrimonial para operar a favor de sua agenda, Vargas criou, em janeiro de 1937, o SPHAN ${ }^{13}$, (BRASIL, 1937). Era o patrimônio a serviço do Estado para a construção de uma nação com personalidade própria e que passou a utilizar o barroco mineiro ${ }^{14}$ como referência identitária. Esse foi um marco do ponto de vista legal para a questão do patrimônio, ainda que possa ser entendido como um período de 'patrimônios decretados', ou seja, baseados numa imposição do que deveria ser a identidade cultural brasileira.

\footnotetext{
7 Tratava-se de um período de conflito entre as elites oligárquicas e o governo provisório liderado por Getúlio Vargas, logo após a deflagração da revolução de 1930.

${ }^{8}$ Atual IPHAN, Instituto do Patrimônio Histórico e Artístico Nacional.

${ }^{9}$ Vargas tinha um projeto de Nação cunhado a partir de ideais nacionalistas e anticomunistas, levado a cabo através da centralização do poder e do autoritarismo.

${ }^{10}$ Rodrigo Melo Franco de Andrade e Lucio Costa são algumas das personalidades que figuram em destaque no cenário da preservação do patrimônio no período getulista.

${ }_{11}$ Apesar das primeiras ações concretas em relação a preservação do patrimônio se darem no Estado Novo com a instituição do tombamento, é possível observar uma maior compreensão da necessidade de proteger desenvolvendo-se lentamente no cenário brasileiro. Assim, cumpre considerar que essa preocupação de preservar o patrimônio começa a tomar forma em fins do século XIX, em 1838, quando da criação do Instituto Histórico e Geográfico do Brasil - IHGB, e do Arquivo Nacional.

${ }^{12}$ Cabe mencionar que, à exceção da chamada Constituição Cidadã (1988), de que trataremos mais adiante, houve poucas alterações nas Constituições que sucederam: na de 1946, foram incluídos os documentos de valor histórico ou artístico no grupo dos bens protegidos (Art. 175) enquanto na de 1967, foram acrescentadas as jazidas arqueológicas.

${ }^{13}$ SPHAN e IBGE - Instituto Brasileiro de Geografia e Estatística (criado em 1938 oriundo do Instituto Nacional de Estatística e do Conselho Nacional de Geografia) - são órgãos que em mãos do governo embasaram e orientaram o planejamento de suas estratégias políticas e foram fundamentais na fundação do discurso e no estabelecimento das práticas do governo de Vargas.

${ }^{14}$ No período em que Rodrigo de Melo esteve à frente do SPHAN, grande parte dos monumentos e obras de arte tombadas estava relacionada ao chamado barroco mineiro, visto que a região de Ouro Preto era tida como modelo estético para a identidade nacional (SANTOS, GONÇALVES e BOJANOSKI, 2012, 22).
} 
Na mesma linha seguiu o Decreto-lei no 25, de 30 de novembro de 1937 (BRASIL, 1937) cujo fim é organizar a proteção do patrimônio histórico e artístico nacional, pautado visivelmente pelos bens pertencentes às elites ou à história oficial, utilizando o instituto do tombamento como norma da tutela patrimonial. Como reiteram Batista e Macedo (2008, 245), "O instituto legal do tombamento foi, até bem pouco tempo, o único instrumento de preservação do patrimônio cultural brasileiro de que o poder público dispunha".

Para explicar melhor a questão, é importante destacar que o regramento federal referendou o disposto na Constituição de 1937 no que tange à abrangência de bens que constituem o patrimônio histórico e artístico nacional, sintetizando-os no sentido dos bens móveis e imóveis que abrigam aqueles de interesse público para a preservação por sua vinculação a fatos memoráveis da história do Brasil ou por seu excepcional valor arqueológico, etnográfico, bibliográfico ou artístico.

De outra parte, sua inovação foi a instituição da figura jurídica do tombamento e dos seus efeitos, outorgando ao Poder Público a autoridade de atribuir valor cultural a determinados bens escolhidos pelo Estado. Segundo Santos, Gonçalves e Bojanoski $(2012,23)$, a "institucionalização do tombamento surge para dar ao Estado o direito de atuar no tombamento de bens de particulares". 0 poder de legitimação do status de bem patrimonial era, portanto, do Estado e foi amplamente utilizado para forjar uma identidade nacional que interessava à política autoritária em vigor à época, como aludido anteriormente, ou seja, "Dentro de um Estado Totalitário e Nacionalista, o Patrimônio Nacional tem a sua importância como legitimador de um poder central", conforme aludem Carlan e Funari $(2008,153)$.

Há que se considerar, no entanto, que a pauta da Cultura entrou formalmente na Administração Federal apenas em 1953, quando da sua incorporação no Ministério da Educação e Saúde através da criação do Ministério da Educação e Cultura (MEC) ${ }^{15}$. 0 governo de Vargas, foi ainda responsável pela instituição da figura jurídica do "destombamento" (BRASIL, 1941), qual seja, norma que dispõe sobre o cancelamento de tombamento de bens do patrimônio histórico e artístico nacional. 0 decreto teria sido uma "decisão casuística"16 cujo sentido efetivo era desembaraçar o avanço de algumas obras no país de interesse do governo, sob justificativa de interesses coletivos (PRIESTER e NITO, 2015). Mais uma vez, as normas são mecanismos através do qual o poder do Estado opera.

Anos mais tarde, já durante o período da ditadura militar (1964-1985), foi aprovada a Lei no 4.845, de 1965 (BRASIL, 1965), que "proíbe a saída, para o exterior, de obras de arte e ofícios produzidos no país, até o fim do período monárquico" (1889), assim como de obras relacionadas ${ }^{17}$ (BRASIL, 1965). Estabeleceu-se, então, limites para a o trânsito internacional de bens culturais no sentido de combater o tráfico ilícito do patrimônio material. Trata-se de um instrumento legal importante, considerando que os bens nacionais circulavam sem controle tanto interna quanto externamente ao país. Outra lei em sentido paralelo foi a Lei no 5.471, de 9 de Julho de 1968 (BRASIL, 1968), que "dispõe sobre a exportação de livros antigos e conjuntos bibliográficos brasileiros".

Anos mais tarde o IPHAN, então Instituto Brasileiro do Patrimônio Cultural - IBPC, divulgou a Portaria nํㅗ 262, de 14 de Agosto de 1992 que "veda a saída do Pais de obras de arte e outros bens tombados sem a prévia autorização do IBPC" (IBPC, 1992). A Portaria normalizou o processo dos pedidos que objetivem tais saídas e definiu as regras para os casos autorizados.

Como aludem Batista e Macedo $(2008,246)$, na década de 1970 se inicia um período em que os critérios da política de patrimônio cultural passaram a ser reexaminados e reconsiderados sistematicamente, culminando com o alargamento conceitual e a incorporação dos aspectos simbólicos assumidos na Constituição de 1988. Destacamos, desse período, a alteração promovida no Decreto-Lei n.o 25/1937 através da Lei no 6.292, de 15 de dezembro de 1975, que tornou o tombamento de bens em nível federal dependente de homologação do Ministro de Estado da Educação e Cultura, após parecer do respectivo Conselho Consultivo. 0 poder do Estado foi, então, ampliado e mais uma vez estabelecido em lei, pois, ainda que pessoas naturais ou jurídicas pudessem manifestar interesse no tombamento, cabia ao SPHAN, após juízo do Conselho Consultivo, inscrever o bem em um dos Livros Tombo, assim como conceder autorização para qualquer intervenção nos bens tombados.

O ano de 1979 ficou marcado como o início da fase moderna do SPHAN, quando Aloísio de Magalhães assume sua direção. As premissas de identificar, tombar e preservar monumentos, características da fase heroica que teve Rodrigo de Melo no comando, e que tinha o patrimônio histórico e artístico como objeto, são então

${ }^{15}$ A Saúde passou a ter pasta própria com a criação do Ministério da Saúde.

${ }^{16}$ Conforme relato do então diretor do IPHAN, Cyro Lyra, em reportagem de Thiago Guimarães publicada na Folha de São Paulo em 2005.

${ }^{17}$ Além destas, a lei inclui também as oriundas de Portugal e incorporadas ao meio nacional durante os regimes colonial e imperial e as obras produzidas no estrangeiro representativas do país no mesmo período (BRASIL, 1965). 
suplantadas por pressupostos antropológicos, tomando como foco um patrimônio com maior abrangência e acercando-se do conceito de bem cultural que, aos poucos, se consolidava ${ }^{18}$. Passa a operar então, como órgão executivo da preservação, a Fundação Pró-Memória ${ }^{19}$, atuando conjuntamente com o SPHAN, que passou a ser um órgão normativo (SANTOS, GONÇALVES e BOJANOSKI, 2012, 24).

Logo a seguir, com o fim da ditadura militar em 1985, deu-se início ao período de redemocratização do Brasil. A partir desse momento as atribuições da Cultura ganham relevo com a criação do Ministério da Cultura (MinC), o que outorgou um status maior ao tema do patrimônio no país.

À época foi sancionada a Lei no 7.347 de 24 de julho de 1985 (BRASIL, 1985), tratando-se de importante conquista para a preservação dos bens culturais no plano jurídico. A nova norma, denominada "Lei da Ação Civil Pública" ou "Lei dos Interesses Difusos", disciplina a ação civil pública de responsabilidade por danos causad os ao meio ambiente, ao consumidor, a bens e direitos de valor artístico, estético, histórico e turístico. Além dessas, há que mencionar a Lei no 7.505, de 2 de julho de 1986, que dispõe sobre benefícios fiscais na área do imposto de renda concedidos a operações de caráter cultural ou artístico.

\section{3. "CONSTITUIÇÃO CIDADÃ" COMO MARCO EVOLUTIVO}

A temática patrimonial teve um avanço significativo em 1988. 0 fim da ditadura militar (1985) foi a antessala da promulgação da Constituição Federal (CF) de 1988 (BRASIL, 1988) que colocou a preservação do patrimônio em outro patamar, alargando o conceito jurídico de cultura e de bens culturais (MATTAR, 2012). Essa ampliação conceitual está evidente na forma como foi redigido o Art. 216, que registra o termo patrimônio cultural brasileiro em substituição da expressão "patrimônio histórico e artístico" como aparecia nos documentos anteriores.

A CF de 1988 amplia a legislação relativa ao tema e "define as competências de promoção, regulamentação e fiscalização das práticas de preservação", como menciona Batista e Macedo $(2008,246)$, atribuindo um "papel mais significativo para o âmbito da administração municipal, e a participação popular nos processos". Além disso a carta magna é um marco de vanguarda jurídica, pois passou a reconhecer os bens de natureza imaterial, isto é, trouxe ao nosso ordenamento jurídico os conceitos internacionais de patrimônio cultural (BATISTA e MACEDO, 2008, 247).

Ademais das competências, das questões conceituais e da inclusão dos bens intangíveis, a Constituição de 1988 estabelece, além do tombamento - já instituído pelo Decreto-lei no 25 de 1937 - o registro ${ }^{20}$ e o inventário ${ }^{21}$ como formas de proteção do patrimônio cultural brasileiro. A inclusão dos bens de natureza imaterial e de novas formas de registro pelo Estado, vem ao encontro do que se repercutia no restante do mundo ocidental, posto que, conforme Mattar $(2012,36)$, inseriu no texto "a tendência internacional representada por constituições de outros países, bem como as declarações emanadas da Organização das Nações Unidas - ONU" através da Organização das Nações Unidas para a Educação, a Ciência e a Cultura (United Nations Educational, Scientific and Cultural Organization) - UNESCO 22.

Outro ponto importante da Constituição de 1988 consta em seu Art. 216, uma disposição que não é taxativa, mas exemplificativa, "[...] razão pela qual outras manifestações podem surgir da própria dinâmica da sociedade, resultando na configuração de novos bens culturais" (MATTAR, 2012, 38). Cabe destacar ainda que a Constituição reforça e instrumentaliza o exercício do direito aos bens culturais, tanto no que se refere ao acesso e fruição, quanto à preservação, que passam a ser garantidos por através de medidas judiciais ${ }^{23}$

\footnotetext{
180 conceito de Bem Cultural se consolidou na legislação com a Constituição de 1988.

${ }^{19}$ Extinta em 1990.

${ }^{20} \mathrm{O}$ Registro de Bens Culturais de Natureza Imaterial foi instituído em 2000 através do Decreto no 3.551 . Trata-se de um instrumento legal de preservação, reconhecimento e valorização dos bens que contribuíram para a formação da sociedade brasileira, tais como saberes, celebrações, formas de expressão e lugares.

${ }^{21}$ O Inventário Nacional de Referências Culturais (INRC) é uma metodologia de pesquisa para produzir conhecimento sobre os domínios da vida social aos quais são atribuídos sentidos e valores. Diz respeito a uma concepção antropológica de cultura, advinda da Constituição de 1988. Para saber mais, consultar a página do IPHAN: http://portal.iphan.gov.br/uploads/ckfinder/arquivos/Manual_do_INRC.pdf.

${ }^{22}$ Como agência especializada da ONU, a UNESCO assumiu, desde sua fundação em 1946, "um papel decisivo na tutela do patrimônio cultural e na evolução dos conceitos que o sustentam" (PAGANI, 2017, 41)

${ }^{23}$ Mandado de segurança, ação popular, ação civil pública.
} 
(MATTAR, 2012, 38). Apenas para registro, a regulamentação do patrimônio imaterial ocorreu somente doze anos depois, através do Decreto no 3.551 de 4 de agosto de $2000^{24}$.

Após a virada do século, a ascensão ao poder de grupos políticos ligados à classe trabalhadora, somada ao alargamento do conceito de cultura e de patrimônio, oportunizaram maior participação de coletivos sociais organizados, faz emergir expressões culturais populares, além de dar voz a atores sociais até então apartados do debate sobre a questão patrimonial. Assim, na medida em que os grupos identificaram certa ressonância em suas manifestações, passaram a se tornar mais presentes, seja através da reclamação por políticas públicas para suas demandas, em geral colocadas à margem para manter a supremacia do patrimônio das elites, seja por meio de denúncias de atos lesivos contra o patrimônio cultural. Como aludem Batista e Macedo $(2008,247)$, várias manifestações culturais passaram a ser inscritas, a partir de 2002, nos livros Saberes, Celebrações, Formas de Expressão e Livro dos Lugares.

Entretanto, apesar das alterações no marco legal, no sentido de proporcionar maior participação popular, o poder de decisão manteve-se sendo emanado do centro para a periferia, visto que são os técnicos, a serviço do Estado, que decidem a pertinência dos pedidos (BATISTA E MACEDO, 2008, 245, 250). 0 início do século XXI foi marcado por um olhar mais atento aos museus e suas coleções, havendo a incorporação de normas que instituem, por exemplo, o Sistema Brasileiro de Museus - SBM, em 2004. Dentre outros objetivos, o SBM tinha como finalidade promover o desenvolvimento das ações voltadas para várias áreas, dentre elas a Conservação.

Efetivamente, estava se construindo um ambiente mais democrático para o patrimônio, pensado como um elemento de desenvolvimento através de políticas públicas de inclusão social e de respeito à diversidade cultural, fato que traduzia uma mudança de paradigma. 0 momento político se mostrava bastante promissor dando grande status à Cultura, o que se refletia no campo da Conservação. Um marco foi a inclusão do parágrafo 3ํㅡo Artigo 215 da Constituição de 1988, através da Emenda Constitucional no 48 de 2005.

Nessa oportunidade foi previsto o estabelecimento de uma lei para a criação do Plano Nacional de Cultura (PNC), concebido anos mais tarde, em dezembro de 2010. 0 PNC é um programa que propõe reunir políticas públicas para o setor cultural transformadoras e democratizadoras quanto ao incremento dos investimentos. Surge, assim, a Lei $\mathrm{n}^{\circ} 12.343$, de 2 de dezembro de 2010, apresentando 53 metas ousadas relativas à área da Cultura.

Esta lei criou também o Sistema Nacional de Informações e Indicadores Culturais - SNIIC. O PNC estava previsto para durar dez anos e tinha o objetivo de transformar a cultura em um núcleo de desenvolvimento econômico.

Um ano antes da instituição do PNC, foi promulgado o Estatuto de Museus e a criação do Instituto Brasileiro de Museus - IBRAM, através das leis no 11.904, de 14 de janeiro de 2009 e oㅡ 11.906, de 20 de janeiro de 2009, respectivamente, ambas normas igualmente relevantes. A primeira, por ser uma lei que abriu caminho na esfera legal para que os bens culturais móveis e sua conservação tivessem sua importância reconhecida, ao apresentar diretamente os temas da preservação, da conservação e da restauração. A norma previu os princípios dos museus e determinou, dentre outras tantas regras, a necessidade dos museus garantirem a conservação e a segurança de seus acervos e de disporem de instalações adequadas para o cumprimento de suas funções.

De outra parte, a criação do IBRAM atendeu à Política Nacional dos Museus - PNM ${ }^{25}$ lançada em 2003 pelo Ministério da Cultura, que apresentou como grande objetivo a preservação e a fruição do patrimônio cultural brasileiro, considerado como um dos dispositivos de inclusão social e cidadania. O IBRAM tem como órgão antecessor, o Departamento de Museus e Centros Culturais - DEMU, criado em 2004 como ponto de partida para o estabelecimento de um órgão específico para a gestão de políticas públicas para os museus. O DEMU era uma instância departamental dentro do IPHAN e a evolução para o IBRAM revela o reconhecimento da Administração Pública das especificidades demandadas pela Política Nacional de Museus.

Outra norma que demonstra uma preocupação mais direta com os bens culturais móveis não tombados em comercialização, é a Instrução Normativa IPHAN no 01, de 11 de junho de 2007 IPHAN, 2007), alterada pela Instrução Normativa IPHAN no 01 , de 12 de janeiro de 2017 (IPHAN, 2017). 0 objetivo foi estabelecer o

\footnotetext{
${ }^{24}$ Institui o registro dos bens intangíveis, criou o "Programa Nacional do Patrimônio Imaterial" e estabeleceu os quatro livros de inscrição dos bens intangíveis, a saber, o Livro de Registro dos Saberes, o Livro de Registro das Celebrações, o Livro de Registro das Formas de Expressão e o Livro de Registro dos Lugares.

${ }^{25}$ A PNM foi uma mudança de paradigma promovida pelo Ministério da Cultura na medida em que passou a contemplar todos os museus brasileiros, independentemente da sua vinculação institucional, ou de sua natureza pública ou privada, considerando necessária a articulação entre Estado e sociedade civil.
} 
Cadastro Especial dos Negociantes de Antiguidades, de Obras de Arte de Qualquer Natureza, de Manuscritos e Livros Antigos ou Raros, de que tratam os artigos 26 e 27 do Decreto-lei 25/37. Percebe-se que o problema do comércio de bens móveis e do tráfico ilícito permanece, apesar das leis da década de 1960, como uma adversidade a ser combatida. A necessidade de novas normas também demonstra que o manejo do campo, apesar de não se limitar apenas à criação de leis, depende destas para estabelecerem os caminhos de sua organização e avanço.

As leis supracitadas, do Estatuto de Museus e do Instituto Brasileiro de Museus, tiveram seus dispositivos regulamentados pelo Decreto no 8.124, de 17 de outubro de 2013 (BRASIL, 2013. Este decreto, além de ter outorgado ao IBRAM a competência de regular, fomentar e fiscalizar o setor museológico, determinou que este órgão é responsável por regular, coordenar e manter atualizado para consulta o Inventário Nacional dos Bens Culturais Musealizados ${ }^{26}$ e o Cadastro Nacional de Bens Culturais Musealizados Desaparecidos ${ }^{27}$, dentre outros registros. Ademais, encarregou o IBRAM de ser responsável por elaborar, divulgar e manter atualizado material com recomendações técnicas relacionadas à preservação, conservação, documentação, restauração e segurança dos bens culturais musealizados e declarados de interesse público, dentre outras incumbências. Trata-se de um momento que distingue os acervos e museus em um cenário de alinhamento aos conceitos internacionais.

Apesar dos esforços de desenvolvimento deste amplo setor, repleto de particularidades atinentes a um país de dimensões continentais, o IBRAM chegou a ser extinto para dar lugar a uma agência de caráter privado, a Agência Brasileira de Museus - ABRAM, através da Medida Provisória no 850, o que, em caso de aprovação, representaria um retrocesso aos avanços já alcançados. Afortunadamente, a mobilização do setor logrou a rejeição da MP e manteve-se o funcionamento da autarquia, ainda que o desmantelamento tenha seguido seu curso, especialmente após a consumação do projeto político em vigor.

Situação semelhante está ocorrendo com o mencionado PNC, que não evoluiu como esperado. Segundo dados informados no sítio eletrônico da Secretaria Especial da Cultura ${ }^{28}$, das cinquenta e três metas propostas em 2010, apenas uma havia sido cumprida em 2018 e dezesseis estavam sem andamento. Há que se chamar a atenção para o fato de que, de 2018 até o presente, nenhum dado foi incluído nas tabelas e gráficos divulgados eletronicamente. A situação de inércia do PNC é um claro reflexo da perda de status da área cultural no atual governo, o qual, dentre outras ações, promoveu a extinção do Ministério da Cultura MinC através da medida provisória no 870 de $1^{\text {o }}$ de janeiro de 2019, convertida posteriormente na Lei $\mathrm{n}^{\mathrm{o}}$ 13.844, de 18 de junho de 2019. A pasta foi absorvida, então, pelo recém criado Ministério da Cidadania e, posteriormente, pelo Ministério do Turismo. 0 que restou desta pasta foi transferido para a Secretaria Especial de Cultura, órgão subordinado atualmente ao Ministério do Turismo. Encontramo-nos diante de um cenário pouco favorável para dezembro de 2020, período que coincide com o término do prazo de conclusão do PNC, especialmente se analisarmos cada meta pontualmente, uma vez que fica evidente a redução dos índices ano após ano.

\section{TRAJETÓRIA DA REGULAMENTAÇÃO PROFISSIONAL}

Em tese a profissão do conservador-restaurador nasce a partir da interação de três instâncias: o próprio profissional; os objetos, ou patrimônio; e o interesse público, ou, sociedade (RUIZ DE LACANAL, 2018). Pode-se afirmar, entretanto, que o primeiro passo para regulamentar uma profissão é estabelecer as suas competências.

Ao analisar a legislação brasileira no que tange ao patrimônio, percebe-se que pouco é mencionado acerca dos profissionais competentes para o cuidado dos bens culturais. A ênfase não está posta nesse aspecto, mas nas práticas de conservação e restauração de bens culturais móveis. A delimitação acontece, no entanto, junto aos bens imóveis, cuja responsabilidade é atribuída aos arquitetos pelas competências do trato com as edificações, porém não necessariamente está atrelada ao conhecimento e formação teórico-prática em Conservação do patrimônio.

\footnotetext{
${ }^{26}$ O Inventário Nacional dos Bens Culturais Musealizados é um instrumento de proteção e preservação do patrimônio museológico, normatizado pela Resolução Normativa nº 1, de 31 de julho de 2014. Não constam informações no sítio do IBRAM a respeito da conclusão dos trabalhos.

27 O CBMD foi lançado em 2019 e está disponível em: http://sca.ibram.gov.br/cbd_publico/

28 Para conhecer mais profundamente os dados, ver a página do PNC em: http://pnc.cultura.gov.br/
} 
Dados do Conselho de Arquitetura e Urbanismo do Brasil (CAU/BR) de fevereiro de 201929, informam que há 165 mil arquitetos e 24 mil empresas da área cadastradas na autarquia. Já o Censo dos Arquitetos e Urbanistas do Brasil realizado em 2012, informa que 66,14\% dos profissionais não tem curso de pósgraduação e que apenas $1,78 \%$ atuaram na área do patrimônio nos últimos dois anos anteriores ao estudo estatístico. Deduz-se, a partir desses números, que poucos arquitetos possuem especialização na área de Conservação.

Por outro lado, o campo do patrimônio consta no rol de atuação dos arquitetos e urbanistas junto ao Conselho de Arquitetura e Urbanismo do Brasil - CAU/BR, responsável por fiscalizar, regulamentar e promover a atividade desses profissionais em âmbito nacional. 0 CAU/BR regula a área na Resolução № 21/2012 ${ }^{30}$ (CAU, 2012). Essa resolução detalha o conteúdo do Artigo 2o da Lei no $12.378 / 2010^{31}$ (BRASIL, 2010), que estabelece como campo de atuação, dentre outros, o

Patrimônio Histórico Cultural e Artístico, arquitetônico, urbanístico, paisagístico, monumentos, restauro, práticas de projeto e soluções tecnológicas para reutilização, reabilitação, reconstrução, preservação, conservação, restauro e valorização de edificações, conjuntos e cidades (BRASIL, 2010).

Como se observa, a atuação sobre os bens imóveis está oficialmente a cargo dos arquitetos e urbanistas, o que é considerado legítimo ${ }^{32}$. Entretanto, os conservadores-restauradores, apesar do reconhecimento de necessidades específicas de qualificação, permanecem pleiteando a regulamentação do próprio ofício.

O que está em jogo é a delimitação e regulação de sua atuação, especialmente no que toca aos bens móveis, atribuições nas quais este é o profissional capacitado.

Tal demarcação de competências se deu a partir da década de 1980, fruto da própria evolução da área e da consolidação do conceito de patrimônio cultural como compreendemos hoje. O novo conceito de patrimônio acabou sendo um dos elementos provocadores da redação de um dos marcos que estabelecem, detalhadamente, a profissão do conservador-restaurador em nível internacional. Trata-se do documento The Conservator-Restorer: a Definition of the Profession (O Conservador-Restaurador: uma definição para a profissão) ${ }^{33}$ publicado pelo International Council of Museums - Committee for Conservation (Comitê para Conservação do Conselho Internacional dos Museus) - ICOM-CC em meio ao encontro trienal desta organização, ocorrido em Copenhague, em setembro de $1984^{34}$. Esse texto representa um ponto de inflexão na medida em que estabelece os objetivos básicos, princípios e requisitos da profissão. Ademais, revelou a transformação do perfil profissional, antes identificado com os artesãos ou artistas plásticos e que passou a ser delineado como um profissional especializado.

Cumpre destacar que, em nível internacional, algumas organizações relacionadas com a questão da Conservação já vinham sendo fundadas, o que demonstra claramente o avanço da importância deste campo profissional, a exemplo do Instituto Internacional para Conservação de Obras Históricas e Artísticas (International Institute for Conservation of Historic and Artistic Works - IIC), fundado em 1950, tendo como preocupação melhorar a prática profissional, fomentar publicações científicas e o treinamento para elevar os padrões técnicos. A criação do Centro Internacional para o Estudo da Preservação e Restauração do Patrimônio Cultural (International Centre for the Study of the Preservation and Restoration of Cultural Property - ICCROM), em 1959, é vista como resposta à destruição generalizada da II guerra, tendo como objetivo ser um centro intergovernamental para estudar e melhorar os métodos de restauração.

No curso desse processo, outras instituições vão sendo edificadas, momento que coincide com o amadurecimento da profissão. Surge assim, em 1991, a Confederação Europeia da Organização de

${ }^{29}$ Informações obtidas na apresentação do Portal da Transparência do CAU/BR disponível em: https://transparencia.caubr.gov.br/apresentacao/

${ }^{30}$ Outro documento, a Resolução no $51 / 2013$, descreve quais áreas de atuação são privativas dos arquitetos e urbanistas e quais são compartilhadas com outros profissionais e que incluem serviços técnicos do patrimônio histórico cultural e artístico (grifo nosso). No entanto está suspensa até 30 de novembro de 2020 (DELIBERAÇÃO PLENÁRIA DPOBR № 0102-01/2020).

${ }^{31}$ A lei regulamenta o exercício da Arquitetura e Urbanismo e cria o CAU/BR e os Conselhos Regionais. Antes da regulamentação do exercício abordada nessa lei, e da resolução mencionada acima, que eleva os arquitetos e urbanistas a uma categoria uniprofissional, os profissionais estavam regidos pela Lei no 5.194, de 24 de dezembro de 1966, que regula o exercício das profissões de engenheiro, de arquiteto e de engenheiro agrônomo.

${ }^{32}$ Há discussão, no entanto, no que se refere aos bens integrados ao patrimônio edificado, campo de disputa entre os arquitetos e os conservadores-restauradores.

${ }^{33} \mathrm{~A}$ íntegra do texto está publicada na página do ICOM-CC: http://www.icom-cc.org/47/about/definition-of-profession1984/\#.X4XHD5NKiL8

${ }^{34} \mathrm{~A}$ publicação é baseada em um texto de Agnes Ballestrem apresentado ao Comitê de Regras e Formação do ICCROM em 1978 e nas posteriores discussões do ICOM e de seu Comitê de Conservação. 
Conservadores-Restauradores (European Confederation of Conservator-Restorers' Organisations E.C.C.O.), que congrega várias organizações de profissionais da Europa, antecipando o surgimento da Associação Profissional de Conservadores-Restauradores de Portugal (ARP), em 1995, e a Rede Europeia de Educação para Conservação e Restauração (European Network for Conservation-Restoration Education - ENCoRE), em 1997, a qual foi concebida com o fito de promover a investigação e a educação no domínio da Conservação do patrimônio cultural.

Isto posto, a conformação do perfil profissional do conservador-restaurador está sendo lentamente forjada, cuja regulamentação expressa o triunfo de uma árdua disputa que teve êxito em poucos países. No Brasil o estatuto legal da profissão é discutido formalmente desde 2005, como discorreremos mais adiante. É mister frisar que as raízes desta profissão remetem ao final do século XIX, ainda que com um viés profundamente ligado ao campo das artes e com um perfil direcionado à restauração estética. Castro (2013) afirma, em sua tese de doutoramento, que o profissional aparece no quadro funcional da administração pública desde 1855, quando da reforma da Academia Imperial de Belas Artes - AIBA, momento em que é instituído o cargo de "Restaurador de Quadros e Conservador da Pinacoteca".

Referimo-nos aqui, portanto, aos primórdios da profissão no país, que nasceu subordinada ao campo da pintura e assim permaneceu por muito tempo no âmbito do funcionalismo público, ainda que com diversas alterações de nomenclatura e de status ao sabor dos altibaixos da política de proteção de bens patrimoniais.

De outra parte, é possível verificar, no campo específico da Conservação, que já nos anos 1930 havia uma "tendência ao reconhecimento e oficialização de uma profissão" (PAGANI, 2017, 85), ainda que tenha sido o diploma em museologia o exigido no primeiro concurso público para provimento do cargo de Conservador de Museu (Museu Nacional de Belas Artes) do Ministério da Educação e Saúde, em 1939.

Há que frisar o fato de que, até então os conservadores-restauradores eram escolhidos pelos diretores das instituições ${ }^{35}$. Regina Liberalli, profissional que assumiu o cargo, demonstrou franca sintonia ${ }^{36}$ com a tendência que se impõe na Europa no começo do século XX, época em que haviam sido adotados os princípios científicos da restauração, cujas bases foram lançadas pelo Escritório Internacional de Museus da Liga das Nações em 1930 em uma conferência internacional ${ }^{37}$ sobre o tema (ROSADO, 2011, 86). A posse da candidata aprovada revela que as instituições da época acompanhavam as tendências internacionais da conservação moderna, na qual os exames de laboratório e os conhecimentos da arte técnica passaram a sustentar o campo de atuação ${ }^{38}$.

Percebe-se, portanto, que a conformação desse profissional mantinha-se circunscrita basicamente à esfera pública (PAGANI, 2017, 90). Coincidimos com Castro quando reitera que se trata de "[...] uma atividade profissional silenciada por entre os bastidores e porões de museus, não alcançando, por conseguinte, a sua visibilidade social e seu reconhecimento político quando comparada às demais profissões" (CASTRO, 2013, 234). Castro agrega ainda que, considerando o universo das instituições por ele estudadas, que o profissional conservador-restaurador foi construído a partir de componentes diferenciados e, portanto, não demonstra articulação entre as instituições nem interlocução com seus pares. Segundo este autor, a criação da Associação Brasileira de Conservadores-Restauradores - ABRACOR, nos anos 1980, viria a contemplar essa carência, em que pese o fato de, a partir de uma ideologia comum, congregar os profissionais isolados em seus respectivos espaços de trabalho (CASTRO, 2013, 238).

Por essa razão e devido à ampliação do número de profissionais atuando sobre o patrimônio cultural móvel brasileiro, seja em museus, bibliotecas, arquivos ou até mesmo em ateliers particulares, fez-se necessária a participação de organizações fora do âmbito da administração pública. Além da ABRACOR, as décadas de 1980 e 1990 foram marcadas pela aparição de diversas associações de profissionais atuantes na conservação e restauração de bens culturais, tais como: Associação Catarinense de Conservadores e Restauradores de Bens Culturais - ACCR, primeira associação estadual, criada em 1987; Associação Brasileira de Encadernação e Restauro - ABER, fundada em em 1988; Associação Paulista de Conservadores e Restauradores de Bens Culturais - APCR, de 1994; Associação de Conservadores e Restauradores de Bens

\footnotetext{
${ }^{35}$ À exemplo da AIBA que voltaremos a mencionar na próxima seção, "Trajetória da regulamentação da profissão do conservadorrestaurador".

36 Para saber mais, ver a tese de doutorado de Aloísio Arnaldo Nunes de Castro, disponível em: https://repositorio.ufmg.br/bitstream/1843/JSSS-9GGJEC/1/tese_aloisio_arnaldo_nunes_de_castro.pdf

${ }^{37}$ Conferência Internacional para o Estudo de Métodos Científicos Aplicados para o Exame e Conservação de Pinturas.

${ }^{38}$ Cabe destacar, a atuação do artista plástico e restaurador Edson Motta no IPHAN do Rio de Janeiro, no cargo de "Perito em Belas Artes", o qual tomou posse em 1944. Motta nos seus 30 anos de atuação no IPHAN e na Escola de Belas Artes da Universidade Federal do Rio de Janeiro - EBA/UFRJ, onde ministrava a disciplinas de restauração, acabou formando inúmeros profissionais, alicerçados nos referenciais científicos da restauração, havendo trazido para o Brasil a "restauração científica" a partir de sua formação realizada no Fogg Museum, em Harvard, sustentada nos referenciais dos estudos técnicos e científicos
} 
Culturais do Rio Grande do Sul - ACOR-RS, criada em 2003; e Associação de Restauradores e Conservadores de Bens Culturais - ARCO.IT, no Paraná, que iniciou seus trabalhos igualmente em 2003.

As entidades regionais colaboraram intensamente com a ABRACOR na busca pela consolidação da área no país, as quais seguem envidando esforços em prol da união dos profissionais em torno a objetivos afins, especialmente em relação ao reforço identitário como classe profissional que anseia o reconhecimento legal. E é em razão desse cenário de interlocução de profissionais de vários estados brasileiros, sejam autônomos ou formalmente ligados às mais diversas instituições, que se instaura o debate da regulamentação profissional. Tal questão se inscreve no campo dos debates acerca da definição da profissão apresentada pelo ICOM-CC em 1984, como aludido anteriormente.

A construção profissional, portanto, está marcada pela luta pelo reconhecimento da área como tal, em que pese o fato de uma existência de fato, mas não de direito.

Além disso, há que considerar o elevado grau de invisibilidade social a que tal ofício acha-se submetido, não somente pelos órgãos públicos como sobretudo pela sociedade civil. As primeiras iniciativas datam dos anos 1990, contudo não avançaram, iniciando, de fato, somente em 2005, durante um encontro de conservadores-restauradores de diversos estados ocorrido na Pinacoteca de São Paulo. Nesse encontro as primeiras discussões foram levadas a efeito a partir de iniciativa das entidades representativas ${ }^{39}$ e de alguns profissionais autônomos.

Um ano mais tarde, em setembro de 2006, no XII Congresso da ABRACOR, o primeiro texto redigido por um grupo de profissionais foi apresentado, sendo disponibilizado logo em seguida na página da associação para uma avaliação de mais profissionais, já que nem todos estavam presentes no congresso supra mencionado. Para atender representativamente a categoria, em outubro do mesmo ano, foi realizada uma reunião específica entre os membros das associações APCR, ABRACOR e ABER, momento em que surgiu a reivindicação de inclusão dos técnicos de nível médio e tecnólogos que não estavam contemplados no texto inicial.

A discussão foi levada ao I Encontro de Conservadores-Restauradores realizado na Câmara dos Deputados, em novembro do mesmo ano, na Mesa "Profissão Restaurador - Regulamentação", que debateu a formação profissional e a regulamentação, oportunidade em que o presidente da Comissão de Educação e Cultura, deputado Carlos Abicalil, se dispôs a encaminhar um projeto de lei com as alterações propostas, sugerindo, inclusive, que a criação dos conselhos federais e estaduais não deveria estar atrelada à proposta, pois provavelmente restaria vetada ${ }^{40}$. Decorrido mais um ano (junho de 2007), ABER e ABRACOR anunciaram o novo texto. Não obstante, dias depois o Senador Edison Lobão apresentou no Senado proposição de um Projeto de Lei, o PL no 370/2007, que teria sido construíd o com base em sugestão de profissionais do Centro de Conservação e Restauração da Escola de Belas Artes da Universidade Federal de Minas Gerais ${ }^{41}$ CECOR//EBA/UFMG ${ }^{42}$.

O texto desse PL restringia a atuação profissional apenas aos diplomados, excluindo os técnicos da regulamentação, além de manter a questão da criação dos conselhos. Um mês depois, em agosto de 2007 em reunião com o deputado Carlos Abicalil foram dirimidas algumas dúvidas e as orientações permitiram a conclusão do texto da ABER e ABRACOR, o qual foi entregue em 24 de setembro de 2007 à presidência da Câmara dos Deputados. Sendo a inclusão dos técnicos um ponto de embate, a redação desse texto propunha a regulamentação e a definição de competências e atividades nos vários níveis profissionais (superior: bacharel e tecnólogo, médio: técnico) desde o Cientista da Conservação - ou Administrador da Preservação, até o técnico em Conservação e Restauração de Bens Culturais.

Assim, um novo projeto, o PL no 3053/2008, apresentado em agosto de 2008 pelo deputado Carlos Abicalil, começou a tramitar. Nestes termos, havia dois projetos de lei - com diferenças significativas - tramitando paralelamente. Em setembro do mesmo ano, o senado aprovou o PL 370/2007 que seguiu para a Câmara

\footnotetext{
${ }^{39}$ ABRACOR, ABER, ACCR, ARCO.IT e APCR.

${ }^{40} \mathrm{~A}$ criação dos Conselhos Profissionais é uma atribuição do Poder Executivo e não do Legislativo, logo, propor legislação a respeito resultaria em inconstitucionalidade.

${ }^{41}$ A EBA/UFMG possuía desde 1978 um Curso de Especialização em Conservação e Restauração de Bens Culturais, extinto somente em 2008 quando da criação do primeiro bacharelado em Conservação e Restauração de Bens Culturais Móveis do Brasil. O CECOR foi criado em 1980 como órgão complementar da EBA para apoiar e desenvolver ensino, extensão e pesquisa na área.

${ }^{42}$ Todas essas informações relativas aos conflitos do encaminhamento da regulamentação da profissão, encontravam-se publicadas no sítio eletrônico da ABRACOR, porém, o domínio da associação está inativo, restando apenas a página do Facebook da entidade que não apresenta esse conteúdo, apenas notícias e publicações específicas.
} 
dos Deputados, sendo este apensado ao PL 3053/2008, aglutinados, agora, sob um novo número, o PL no $4042 / 2008.43$

Com a união dos dois projetos, e sendo estes divergentes entre si, em dezembro de 2008 o Deputado Nelson Marquezelli, da Comissão de Trabalho, de Administração e Serviço Público, emitiu parecer sugerindo rejeição do PL 370/2007 e aprovação do 3053/2008. Era notória, portanto, a inconstitucionalidade da criação dos conselhos. Na intenção de aumentar as chances de aprovação tanto na Câmara como no Senado, a categoria chama uma assembleia que sucedeu durante o XIII Congresso da ABRACOR, em Porto Alegre, em abril de 2009. Partindo de votação realizada na assembleia mencionada, foi extraído um texto substitutivo que unificava as duas propostas. 0 documento foi finalizado em maio de 2009 e trouxe as seguintes proposições: a) inclusão dos profissionais de nível técnico; b) supressão das 1000 horas exigidas anteriormente para o curso de especialização; c) aumento para quatro anos a comprovação de atuação na área e d) retirada da proposta de criação dos Conselhos Federal e Estaduais. 0 texto foi aprovado e assinado pela ABRACOR, CECOR e ABER, havendo sido entregue ao relator da Comissão do Trabalho, deputado Mauro Nazif, em novembro de 2009. Este parlamentar emitiu parecer favorável, aprovando, um ano depois o texto que unificava os dois projetos.

O conflito de interesses entre graduados e técnicos estava, em tese, sanado, pois o texto substitutivo contemplava os dois níveis. Além disso, com a retirada da proposta de criação dos conselhos, o trecho que obstaculizava a provação estava vencido. Os trâmites seguiram com certa morosidade e, passados dois anos, o PL substitutivo foi aprovado em outubro de 2012 pela Comissão de Finanças. Em abril de 2013 seguiu para a Comissão de Constituição, Justiça e Cidadania, que elaborou a redação final - aprovada em junho do mesmo ano - e enviou à Mesa Diretora. Nessa instância foi desapensado o PL no 3.053/2008 e remetido ao Senado o PL substitutivo, ainda no mês junho.

Houve, entretanto, uma guinada no andamento do processo, quando em agosto do mesmo ano um parecer do relator do projeto no Senado, Senador Sérgio de Souza, rejeitou o projeto substitutivo e restabeleceu o texto do PL 370/2007, que contemplava apenas os profissionais com curso superior, além de manter o item relativo à criação dos Conselhos. 0 texto, já superado pelas discussões e com falhas na construção, foi para sanção do Poder Executivo, sendo vetado integralmente pela então Presidenta da República, Dilma Roussef, em setembro de 2013, com base na manifestação pró-veto dos Ministérios da Justiça, da Fazenda, do Planejamento, Orçamento e Gestão e a Advocacia-Geral da União.

No veto, a Presidenta remeteu à apreciação do Congresso Nacional, argumentando dois pontos fundamentais. 0 primeiro se referia à 'inconstitucionalidade formal por vício de iniciativa', pois os Conselhos profissionais devem ser demandados pelo poder executivo na figura do Presidente da República, tal como disposto no art. $61, \S 1$, inciso II, alínea e, da Constituição. 0 segundo se remete à violação do disposto no art. $5^{\circ}$, inciso XIII da Constituição, o qual assegura o livre exercício de qualquer trabalho, ofício ou profissão, cabendo a imposição de restrições apenas quando houver risco de dano à sociedade, algo que não corresponde ao ofício de conservador-restaurador (BRASIL, 2013).

0 primeiro argumento do veto, relativo à criação dos Conselhos, já havia sido sinalizado anteriormente, logo era previsível e inquestionável. 0 segundo parece refletir desconhecimento da área de Conservação tanto na instância política quanto no âmbito da Administração Pública. Lamentavelmente as contradições internas à categoria e a invisibilidade da profissão, ficaram nesse ato, francamente manifestos.

Apesar da regulação ser prescindível para considerarmos a existência de uma profissão, o veto demonstrou que a esfera pública no Brasil apresenta um entendimento limitado da complexidade da área, da sua importância como agente efetivo de preservação da memória e do patrimônio cultural. 0 exercício da profissão sem a qualificação e a devida regulação em nada contribui para os interesses do país.

A derrota desarticulou os profissionais que somente em 2017 encaminharam novo projeto, o PL no 9.063, de 2017, proposto pelo então Deputado Federal Chico Alencar (PSOL/DF). 0 texto desse novo projeto é exatamente o mesmo dado pela redação final do PL substitutivo de 2010 (da Câmara) e que, em tese, deveria ter sido apreciado pelo Poder Executivo. 0 novo projeto de lei tramitou na Câmara de Deputados até janeiro de 2019, quando foi arquivado nos termos do Artigo 105 do Regimento Interno da Câmara dos Deputados em virtude do término do mandato do deputado proponente. Em outros termos, tem-se, assim, uma nova derrota.

${ }^{43} 0$ Regimento Interno da Câmara determina em seu Art. 143 que as proposições do Senado terão precedência sobre os da Câmara e que os demais processos de mesmo objeto devem ser apensados ao processo precedente. Por estes motivos, e a fim de evitar decisões conflitantes, o PL 3053/2008, passa a tramitar junto com o PL 370/2007 (renomeado na Câmara para PL 4042/2008). 
Cabe destacar ainda que, nas eleições presidenciais, apenas cinco dos candidatos incluíram o tema do Patrimônio Cultural em seus planos de governo. 0 presidente empossado em 2019 decididamente nada agregou ao tema, senão justamente o contrário, ao reduzir significativamente o status da área da Cultura, além de extinguir o MinC.

Novo projeto foi apresentado, em fevereiro de 2019, na Câmara pela Deputada Fernanda Melchionna. Tratase do PL 1183/2019, cujo conteúdo é idêntico aos dois PL anteriores (9063/2017 e o substitutivo 4042/2008). Este texto foi remetido à apreciação conclusiva pelas comissões de Trabalho, de Administração e Serviço Público e Constituição e Justiça e de Cidadania em março de 2019. Do PL 1183/2019 a última tramitação foi a designação do Deputado Elvino Bohn Gass, da Comissão de Trabalho, de Administração e Serviço Público, como relator do projeto de lei, restando aguardar os pareceres das duas comissões supracitadas.

Outro ponto que afeta a área e que indiretamente está relacionado à questão da não regulamentação, diz respeito ao Decreto no 9.262, de 9 de janeiro de 2018, que extinguiu vários cargos no âmbito da administração pública federal direta, autárquica e fundacional, dentre eles o de conservador-restaurador. Tal medida evidencia a tendência de terceirização dos serviços do Estado, bem como a notória fragilidade da área perante a esfera pública.

Afora as questões enunciadas acima, a área em questão conhece, no caso brasileiro, graves problemas de delimitação e reconhecimento público, em flagrante contradição com o que sucede à escala internacional, especialmente na Europa e Estados Unidos. No caso brasileiro reina completa desinformação sobre quem é esse profissional e quais são as suas competências.

Exemplo tácito do limbo em que se acha submetido o ofício de conservador-restaurador pode ser visto nos documentos da Comissão Nacional de Classificação - CONCLA ${ }^{44}$, quais sejam, a Classificação Brasileira de Ocupações - CBO e a Classificação Nacional de Atividades Econômicas - CNAE ${ }^{45}$. Nas duas classificações a inclusão do profissional revela incongruências. Em síntese, a profissão e/ou as atividades a ela atinentes, se apresentam com certa imprecisão junto aos órgãos oficiais - responsáveis pela classificação e organização do trabalho, o que indica a lacuna de normas que controlem as atividades do campo da Conservação e, pontualmente, dos profissionais que nela atuam.

Outro ponto a destacar está no âmbito da educação superior, onde os cursos de bacharelado em Conservação e Restauração de Bens Culturais são desconsiderados pelas Diretrizes Curriculares Nacionais do Ministério da Educação - MEC ${ }^{46}$, o que denota certa invisibilidade da área frente aos órgãos oficiais.

É assaz complexa a tarefa de estimar o número de agentes que atuam, presentemente, na Conservação de bens móveis no Brasil pelos mais diversos motivos. 0 primeiro deles é que algumas atividades tem seus limites difusos e não é raro que outras áreas se apropriem de tarefas de competência do conservadorrestaurador. 0 segundo motivo é que há um grande número de indivíduos que atuam sem uma formação específica ou que, no limite, realizaram algum tipo de formação de curta duração e se consideram habilitados para o exercício das funções nesse âmbito. 0 terceiro motivo está diretamente associado aos dois anteriores e tem a ver com o fato que o país não dispõe de registro sobre o número de pessoas em atividade nesse campo de atuação profissional.

Dentro desse esforço de mensuração realizou-se, no marco do presente estudo, uma aproximação empírica sobre algumas áreas de formação ligadas à área da Conservação ${ }^{47}$. Com efeito, identificou-se a existência de 37 grupos de pesquisa cadastrados plataforma do Conselho Nacional de Desenvolvimento Científico e Tecnológico - CNPq que, em alguma medida, guardam relação com o patrimônio cultural tangível, os quais se concentram em áreas como Arquitetura e Urbanismo, Arqueologia, Artes, Museologia, Física e História ${ }^{48}$.

\footnotetext{
${ }^{44}$ A CONCLA é um órgão colegiado diretamente subordinado ao Ministério do Planejamento, Orçamento e Gestão. É integrado por dezesseis representantes sendo que desses, um é o Presidente da Fundação Instituto Brasileiro de Geografia e Estatística - IBGE, também responsável pela presidência da Comissão, e os demais são representantes de quinze Ministérios. A CONCLA disponibiliza em sua página as classificações estatísticas nacionais usadas no sistema estatístico e nos cadastros administrativos do país, além das classificações internacionais a elas associadas. Dentre as classificações definidas pela CONCLA, duas particularmente interessam aos conservadores-restauradores, a CBO e a CNAE.

45 Para conhecer mais sobre o assunto, ver Pagani (2017).

${ }^{46}$ Conforme verificado no Portal do MEC, Disponível em: http://portal.mec.gov.br/component/content/article?id=12991, Acessado em 18 de novembro de 2020.

${ }^{47}$ A busca fez uso das palavras" Restauro", "Restauração" e "Conservação" como palavras-chave na consulta parametrizada, excluindose posteriormente os grupos sem identificação com a área do patrimônio cultural.

${ }^{48}$ Vale ressaltar que a área de Conservação não está incluída em nenhuma grande área junto ao CNPq, restando aos investigadores cadastrarem seus grupos de pesquisa em áreas correlatas. Para os casos de patrimônio móvel é recorrente a vinculação com a área de Museologia, dentro das Ciências Sociais Aplicadas.
} 
Sabe-se também da existência atual de quatro cursos de graduação no país, todos em Universidades Federais, os quais já formaram 312 profissionais desde o surgimento dos bacharelados em $2008^{49}$. Em nível lato sensu, os dados do sistema e-MEC do Ministério da Educação informam a existência de dezoito cursos de especialização relacionados aos bens móveis ou imóveis, todos em universidades particulares, com carga horária máxima de 450 horas ${ }^{50}$. Dentre os programas de pós-graduação stricto sensu, desconhece-se no Brasil programa em nível de mestrado e doutorado específico em Conservação de Bens Culturais Móveis. Para suprir essa carência e dada a característica interdisciplinar da Conservação, o profissional usualmente recorre à formação junto a programas em áreas afins, como Artes, Museologia, História, Arquitetura, Arqueologia, dentre outras. Essa é uma resposta interessante de ser perseguida. No entanto, ainda que mereça atenção, a busca por dados relativos ao número estimado de mestres e doutores, cujas dissertações e teses versem sobre o tema da Conservação, é uma tarefa hercúlea e se distancia do escopo deste trabalho. Apenas para situar o leitor, é possível mencionar uma linha de pesquisa em Preservação do Patrimônio Cultural no Programa de Pós-graduação em Artes da UFMG, destinada a investigações sobre bens móveis e imóveis (mestrado de doutorado), além de dois mestrados profissionais dirigidos ao patrimônio edificado, um na Universidade Federal da Bahia e outro oferecido pelo IPHAN. Há também o Programa em Memória Social e Patrimônio Cultural da UFPEL, dentre outros que tangenciam a área.

Em síntese, trata-se de uma área complexa cujos contornos estão sendo moldados em meio à tensões e adversidades. Não obstante, trata-se, sobretudo, de um campo do conhecimento altamente tributário dos investimentos públicos (União, estados e municípios), mas especialmente do modo como a sociedade civil reconhece seus objetos históricos e sua própria cultura como dignos de serem preservados. Todavia, analisar essa questão extrapola os limites que impõe a reflexão aqui desenvolvida.

\section{CONSIDERAÇÕES FINAIS}

A partir do que foi abordado, em particular em relação ao levantamento da legislação relativa ao patrimônio, percebe-se que a área da Conservação avança a passos lentos e claramente à reboque da iniciativa e da tutela do Poder Público. Considera-se válido, portanto, o argumento de que as decisões sobre o que deve ser preservado, como se organiza o setor, as competências e abrangência de suas normas, estão claramente subordinados aos interesses ideológicos dos grupos que estão no poder. Dois momentos poderiam ser apontados como marcantes nesse percurso.

O primeiro se refere ao período oriundo do Estado Novo, em que a renovação cultural dos Modernistas serviu aos ideais políticos da época no sentido de criar um Novo - e unificado - Brasil, nação esta que seria forjada sob o alicerce de um patrimônio decretado. 0 segundo, relaciona-se ao período pós ditadura militar, tendo na promulgação da Constituição de 1988 um marco de referência, justamente por representar um avanço significativo com a ampliação do conceito de bens patrimoniais e incluir no seu repertório o patrimônio imaterial, e, particularmente, ao incorporar no nosso ordenamento jurídico a noção de 'bens culturais'.

A inclusão na legislação do registro dos bens intangíveis, ratifica o reconhecimento do Estado de que o campo tomou novos contornos e de que a tutela patrimonial imaterial é também sua responsabilidade, estando compatível com o cenário de redemocratização do período e com os conceitos internacionais de patrimônio. Percebe-se franco avanço do setor cultural, sobretudo nos primeiros quinze anos do novo milênio, período em que as expressões culturais populares passaram a ser reconhecidas pelo Poder Público, seja através dos registros nos livros relativos ao patrimônio intangível, seja no avanço das políticas públicas como instrumento de inclusão social e cidadania.

\footnotetext{
${ }^{49}$ Universidade Federal de Minas Gerais, Universidade Federal de Pelotas, Universidade Federal do Rio de Janeiro e Universidade Federal do Pará. Fonte: Censo da Educação Superior de 2008 a 2019, disponível no sítio eletrônico do Instituto Nacional de Estudos e Pesquisas Educacionais Anísio Teixeira - INEP (INEP, 2020).

${ }^{50}$ Apenas como comparativo, o curso de especialização do Centro de Conservação e Restauração de Bens Culturais - CECOR/UFMG, que durou trinta anos e deu lugar em 2008 à graduação em Conservação e Restauração da mesma universidade, possuía mais de 2000 horas entre disciplinas obrigatórias, optativas e estágio.
} 
O destaque dado aos museus e seus acervos com a criação do IBRAM, sintonizado à Política Nacional de Museus então estabelecida, reflete o alinhamento do cenário brasileiro aos conceitos internacionais, e reforça a ideia de que o período foi singular para os avanços da área de Conservação no país. Tal período coincide com algumas pequenas conquistas para um campo de atuação profissional que clama atenção para o Estado. A criação dos cursos de graduação em Conservação e Restauração de Bens Culturais Móveis é evidência irrefutável de que a política de desenvolvimento do período estava em plena articulação com a Cultura.

Apesar destes avanços,_também ficou evidente a incompreensão quanto à complexidade da área de Conservação, haja vista um dos argumentos do veto presidencial ao projeto de lei de regulamentação do conservador-restaurador ao desconsiderar os danos à dimensão social de uma possível atuação desqualificada sobre os bens culturais. Cabe destacar aqui o desconhecimento da diversidade de atividades que envolvem o campo da Conservação, ou, ainda, a complexidade na delimitação do próprio campo, considerando que um dos termos mais usados, restauração, é recorrentemente aplicado como sinônimo de reparação pela sociedade, o que reflete problemas de ordem semântica com respeito à área.

Há que se apontar, no entanto, que as dificuldades relativas ao reconhecimento do conservador-restaurador na esfera legal não são um fato exclusivo do Brasil. Tal situação atinge outros países, inclusive no âmbito europeu, como é precisamente o caso da Espanha. Argumentou-se, por exemplo, que a consolidação da área depende da interação tanto do próprio profissional, quanto do interesse público e do próprio patrimônio, ponto que conecta os outros dois. Do mesmo modo, estabelecer as competências do profissional é também o início da caminhada para a regulamentação.

O mercado comum europeu, já tem essa definição. Trata-se do Professional Guidelines (Diretrizes Profissionais) da European Confederation of Conservator-Restorers - E.C.C.O. (Confederação Europeia de Conservadores-Restauradores), onde estão descritas as competências necessárias para o exercício profissional do conservador-restaurador. Além do Código de Ética da área, o texto traz considerações relativas ao âmbito formativo em consonância com o European Qualifications Framework (Marco Europeu de Qualificações), fruto do Acordo de Bolonha. Em contrapartida, isso ainda não foi suficiente para concretizar legalmente a profissão em muitos países, como é o caso da Espanha, que luta pelo reconhecimento há várias décadas.

Em verdade, a formação de um campo profissional é um processo que se desenvolve em meio a uma arena de disputas e conflitos. Não seria diferente para com os conservadores-restauradores brasileiros, cujo exercício profissional passou a se desenhar, com maior clareza, em meados do século XX, posto que seu labor estava, antes disso, substancialmente vinculado ao domínio das artes e da arquitetura. Dentro da própria categoria, a tramitação da regulamentação está marcada por tensões, algo recorrente e legítimo em contextos profissionais que se estão consolidando.

Parece lógico supor que a regulamentação da profissão não pode ser vista como a solução dos problemas do campo da Conservação. Todavia, igualmente razoável pensar ser este um bom começo para que a preservação de nossos acervos e afirmação de nossas multifacetadas identidades. Dentro do entendimento contemporâneo do que vem a ser patrimônio cultural, o conservador-restaurador é, indiscutivelmente, um dos principais atores de preservação, dado o conhecimento aprofundado que é exigido para o trato direto com essa área tão complexa.

Isto posto, entende-se que a regulamentação da profissão é sim um dos caminhos determinantes para que se conquiste uma efetiva normatização para o universo dos bens culturais móveis. A profissão já existe de fato, a qual reivindica, legitimamente, seu reconhecimento por parte do Estado e da sociedade civil. Entretanto, como consequência natural de hiatos legais específicos para a Conservação dos bens culturais móveis, o palco onde atuam os conservadores-restauradores apresenta um ambiente frágil quanto à organização da categoria e também quanto ao exercício profissional no espaço do trabalho. A ligação e suposta subordinação dos bens culturais móveis ao patrimônio edificado, por exemplo, parece indicar que um estudo mais pontual, baseado nos próprios dados divulgados pelo IPHAN, seria capaz de colaborar na compreensão dos motivos pelos quais a profissão do conservador-restaurador apresenta tantas dificuldades de demarcar seu território no campo do trabalho.

Por fim, parece-nos inevitável sinalizar a atual conjuntura político-administrativa do país que se revela na contramão do avanço do campo da Cultura. Cortes orçamentários, rebaixamento do status da Cultura junto à administração pública são exemplos claros dos retrocessos verificados nos últimos cinco anos. Os impactos negativos desse esvaziamento são mais que evidentes, restando a convicção de que algo precisa ser feito para ao menos atenuar os danos ao patrimônio nacional. 


\section{REFERÊNCIAS}

[1] ABRACOR. Boletim Eletrônico da ABRACOR. № 1, junho de 2010. Rio de Janeiro, 2010.

[2] BATISTA, Vanessa Oliveira; MACEDO, Carmen Lúcia. O patrimônio cultural na legislação brasileira. Nomos: Revista do Curso de Mestrado em Direito da UFC. v. 28 n. 1, jan./jun. 2008, p. 237-260, 2008.

[3] BRASIL. Constituição (1988). Constituição Federal da República Federativa do Brasil de 1988. Brasília: Senado Federal, 1988.

[4] BRASIL. Decreto-lei no 25, de 30 de novembro de 1937. Organiza a proteção do patrimônio histórico e artístico nacional. Disponível em: http://www.planalto.gov.br/ccivil_03/decreto-lei/del0025.htm, Acesso em: 15 set. 2020.

[5] BRASIL. Decreto no 8.124, de 17 de outubro de 2013. Regulamenta dispositivos da Lei no 11.904, de 14 de janeiro de 2009, que institui o Estatuto de Museus, e da Lei no 11.906, de 20 de janeiro de 2009, que cria o Instituto Brasileiro de Museus - IBRAM. Disponível em: https://www2.camara.leg.br/legin/fed/decret/2013/decreto-8124-17outubro-2013-777268-norma-pe.html, Acesso em: 15 set. 2020.

[6] BRASIL. Lei no 4.845, de 19 de novembro de 1965. Proíbe a saída, para o exterior, de obras de arte e ofícios produzidos no país, até o fim do período monárquico. Disponível em: http://www.planalto.gov.br/ccivil_03/leis/14845.htm, Acesso em: 18 set. 2020.

[7] BRASIL. Lei no 5.471 , de 9 de julho de 1968. Dispõe sobre a exportação de livros antigos e conjuntos bibliográficos brasileiros. Disponível em: http://www.planalto.gov.br/ccivil_03/leis/15471.htm, Acesso em: 15 set. 2020.

[8] BRASIL. Lei 7.347, de 24 de julho de 1985. Disciplina a ação civil pública de responsabilidade por danos causados ao meio-ambiente, ao consumidor, a bens e direitos de valor artístico, estético, histórico, turístico e paisagístico e dá outras providências. Disponível em: http://portal.iphan.gov.br/uploads/legislacao/Lei_n_7.347_de_24_de_julho_de_1985.pdf, Acesso em: 21 set. 2020.

[9] BRASIL, Presidência da República, Despachos da Presidenta da República, Mensagem no 400, de 18 de setembro de 2013. Mensagem ao Senado Federal do veto ao Projeto de Lei no 370/2007. Diário Oficial da União: Seção 1: Presidência da República, Brasília, ano 150, no 182, p.1, 19 set. 2013.

[10] CARLAN, Cláudio Umpierre; FUNARI, Pedro Paulo Abreu. Resenha de Coletânea de Leis sobre Preservação e Patrimônio. Revista de Arqueologia (Sociedade de Arqueologia Brasileira. Impresso), v.21, p. 152-154, 2008.

[11] CARVAlHo, Ana Paula Corrêa de. O Curso de Especialização em Conservação de Bens Culturais Móveis da Escola de Belas Artes da UFRJ: Contribuições para a preservação do patrimônio. 2018. 252p. Tese (Doutorado em Museologia e Patrimônio). Centro de Ciências Humanas e Sociais, Universidade Federal do Estado do Rio de Janeiro e Museu de Astronomia e Ciências Afins, 2018.

[12] CASTRO, Aloisio Arnaldo Nunes de. Do restaurador de quadros ao conservador- restaurador de bens culturais: o corpus operandi na administração pública brasileira de 1855 a 1980. 2013. 256 f. Tese (Doutorado em Artes). Escola de Belas Artes, Universidade Federal de Minas Gerais, 2013.

[13] CHUVA, Márcia. Intelectuais e Estado: disputas em torno da noção de patrimônio nacional. Anais do Museu Histórico Nacional. Rio de Janeiro, vol. 36, p. 41-51, 2005.

[14] CNPQ. Base de dados Grupos de Pesquisa. Disponível em: http://lattes.cnpq.br/web/dgp/faq;jsessionid=B+amy00Zhy1Nvi9fQ4UjOZ7L.undefined?p_p_id=54_INSTANCE_39Zlb 9kA3d0e\&_54_INSTANCE_39Zlb9kA3d0e_struts_action=\%2Fwiki_display\%2Fview\&_54_INSTANCE_39Zlb9kA3d0e_n odeName=Main\&_54_INSTANCE_39Zlb9kA3d0e_title=11.+Consultar+Grupos+de+Pesquisa, Acesso em: 21 set. 2020.

[15] CONSELHO DE ARQUITETURA E URBANISMO DO BRASIL - CAU/BR. Resolução no 21, de 5 de abril de 2012. Dispõe sobre as atividades e atribuições profissionais do arquiteto e urbanista e dá outras providências. Brasília, 2012.

[16] E-MEC. Base de dados Cadastro Nacional de Cursos e Instituições de Educação Superior. Cadastro e-MEC. Disponível em: https://emec.mec.gov.br/, Acesso em: Acesso em: 21 set. 2020.

[17] FONSECA, Maria Cecília Londres. O patrimônio em processo: trajetória da política federal de preservação no Brasil. 2a ed. Rio de Janeiro: UFRJ; MinC - IPHAN, 2005.

[18] IBPC. Portaria no 262, de 14 de agosto de 1992. Veda a saída do País de obras de arte e outros bens tombados sem a prévia autorização do IBPC. Disponível http://portal.iphan.gov.br/uploads/legislacao/Portaria_n_262_de_14_de_agosto_de_1992.pdf, Acesso em: 14, set. 2020 .

[19] INEP. Sinopse Estatística da Educação Superior. Brasília: Inep, 2020. Disponível em: http://portal.inep.gov.br/basica-censo-escolar-sinopse-sinopse. Acesso em: 12, nov. 2020.

[20] IPHAN. Instrução Normativa no 01, de 11 de junho de 2007. Dispõe sobre o Cadastro Especial dos Negociantes de Antiguidades, de Obras de Arte de Qualquer Natureza, de Manuscritos e Livros Antigos ou Raros, e dá outras 
providências. Disponível em: http://portal.iphan.gov.br/files/Instrucao_Normativa_Negociantes_012007.pdf, Acesso em: 10, out. 2020

[21] IPHAN. Instrução Normativa no 01, de 12 de janeiro de 2017. Altera a Instrução Normativa no 01 , de 11 de junho de 2007, que dispõe sobre o Cadastro Especial dos Negociantes de Antiguidades, de Obras de Arte de Qualquer Natureza, de Manuscritos e Livros Antigos ou Raros. Disponível em: http://portal.iphan.gov.br/uploads/legislacao/instrucao_normativa_01_2017_altera_in_01_2007.pdf, Acesso em: 10, out. 2020.

[22] MATTAR, Eliana. Legislação patrimonial. In: SILVA, Maria Celina Soares de Mello e (org.). Segurança de acervos culturais. Rio de Janeiro: Museu de Astronomia e Ciências Afins, 2012. p. 33-52.

[23] PAGANI, Carlo. O valor da formação profissional para o patrimônio cultural. 2017.216p. Tese (Doutorado em Políticas Públicas e Formação Humana), Faculdade de Educação, Universidade do Estado do Rio de Janeiro. Rio de Janeiro, 2017.

[24] PRIESTER, Mariana Freitas; NITO, Mariana Kimie da Silva. Destombamento, explorando uma política pública controversa: o caso de São João Marcos. In: VI Seminário Internacional de Políticas Culturais, Rio de Janeiro, 2015. Anais do VI Seminário Internacional de Políticas Culturais. Rio de Janeiro: Fundação Casa de Rui Barbosa, 2015.

[25] ROSADO, Alessandra. História da Arte Técnica: um olhar contemporâneo sobre a práxis das Ciências Humanas e Naturais no estudo de pinturas sobre tela e madeira. - 2011. 289p. Tese (Doutorado em Artes) Escola de Belas Artes, Universidade Federal de Minas Gerais, Belo Horizonte, 2011.

[26] RUIZ DE LACANAL, M. D. Conservadores y Restauradores: La historia de la conservación y restauración de bienes culturales. Sevilla, España: Editorial Universidad de Sevilla, 2018. 


\section{Capítulo 10}

Um olhar transdisciplinar sobre a relação entre currículo e educação integral de acordo com a BNCC no Brasil

Gabriela Carradas

Kênia Kemp

Resumo: Compreende-se o conhecimento como a capacidade de contextualizar e englobar o que se aprende. 0 que se tornou um desafio, sendo que, as escolas seguem os princípios cartesianos de fragmentação do conhecimento. Isso suprimiu a possibilidade do pensamento multifacetado e global. Por isso, tornou-se necessário buscar uma nova forma de compreensão da realidade, da humanidade, da cidadania e da ética, que forme sujeitos capazes de enfrentar as diversas crises da humanidade e que visem à construção de um futuro melhor para todos. No Brasil, com a homologação da Base Nacional Comum Curricular em 2017, a educação básica passou a ter um documento norteador que prevê conhecimentos e habilidades essenciais, com uma concepção de educação integral que busca o pleno desenvolvimento que todos os educandos têm direito ao decorrer de suas vidas escolares. Assim, a transdisciplinaridade pode ser promissora como um caminho para enfrentar a fragmentação do conhecimento e auxiliar em uma compreensão mais abrangente da realidade. Essa pesquisa apresenta os conceitos da transdisciplinaridade atrelados ao objetivo de refletir sobre sua inserção na prática pedagógica como forma de resolver os atuais embates educacionais, em consonância com os preceitos almejados pela BNCC. A metodologia utilizada teve finalidade exploratória, desenvolvida com base em pesquisa bibliográfica e documental, através do método hipotético dedutivo e com abordagem qualitativa. Espera-se, contribuir para que a abordagem transdisciplinar seja difundida no campo acadêmico, e assim, conscientizar toda a comunidade escolar acerca de nossa responsabilidade com a educação integral.

Palavras-Chave: Educação integral. Transdisciplinaridade. BNCC. 


\section{INTRODUÇÃO}

A sociedade contemporânea enfrenta um desafio de complexidade que, devido a superespecialização e ao acúmulo de informações desconexas, cada vez mais, afasta as possibilidades de encontrar soluções para os problemas multidimensionais que assolam a humanidade.

A fragmentação do conhecimento é um dos resultados desse mundo descontextualizado. É preciso superar essa visão compartimentada do saber para passar a enxergar e formar o ser como um todo e não somente no âmbito cognitivo, como vem ocorrendo. Por conseguinte, percebe-se a necessidade de colocar o ser humano como centro das civilizações, ao invés de usar o conhecimento para fins egoístas e em razão de poder que, aliás, vai contra a democracia cognitiva.

Em vista disso, tornou-se necessário buscar uma nova forma de compreensão da realidade e da humanidade, que forme sujeitos capazes de enfrentar as diversas crises sociais, econômicas, políticas e ambientais, visando à construção de um futuro melhor para todos.

Assim, a transdisciplinaridade no âmbito escolar, pode ser uma promissora forma de enfrentar a fragmentação do conhecimento e a descontextualização do sujeito/objeto no processo de ensino aprendizagem, para possibilitar um modo de pensar aberto e livre que ajude a compreender a nossa própria realidade.

Face ao exposto, o objetivo geral desse trabalho é mostrar a importância da transdisciplinaridade na educação, em consonância com o currículo e a formação integral almejada pela Base Nacional Comum Curricular (BNCC), como forma de transformar o atual paradigma educacional.

\section{METODOLOGIA}

Conforme Gil (2002), a primeira etapa de uma pesquisa consiste em seu planejamento, na elaboração do problema, na identificação dos objetivos, no desenvolvimento de hipóteses etc. Isto posto, o problema aqui formulado, foi em relação fragmentação do saber na educação básica e de como isso vai contra os objetivos gerais da BNCC para o desenvolvimento integral do ser. Para Corrêa (2008), o problema de pesquisa é aquilo que se pretende resolver e está ligado a hipóteses, que serão uma resposta prévia ao problema. Então, após a formulação do problema, houve a busca por sua solução, constituindo um raciocínio demonstrativo de uma hipótese que soluciona o problema pesquisado. (SEVERINO, 2016, p. 140). Nesta pesquisa, a elaboração da hipótese está apoiada em teorias e estudos anteriores sobre a temática da transdisciplinaridade.

Com base nos objetivos gerais, pode-se classificar a pesquisa em questão como exploratória, que segundo Gil (2002), tem o objetivo de criar maior entendimento sobre o problema e aprimorar ideias, e que, portanto, seu planejamento é bastante flexível.

De acordo com Corrêa (2008), o método dedutivo é um modo de pensamento lógico fundamentado por premissas que, se forem somente hipóteses, passa, então, a ser o hipotético-dedutivo. Em suma, ainda define o método qualitativo como uma técnica que visa entender objetos de estudo, sem preocupação com suas quantidades.

A pesquisa bibliográfica, é realizada a partir de dados ou teorias de pesquisas anteriores, devidamente registradas. Já na pesquisa documental, suas fontes são documentos, não somente impressos, mas também de outros tipos, como documentos legais. (SEVERINO, 2016, p. 131).

Conclui-se então que, a metodologia nesse trabalho foi desenvolvida com base em pesquisa bibliográfica e documental, através do método hipotético dedutivo, com abordagem qualitativa e tendo finalidade exploratória. Assim, possibilitando a correlação entre a teoria explorada, as suas hipóteses dedutivas e a análise dos dados colhidos em documentos nacionais.

\section{FUNDAMENTOS DA TRANSDISCIPLINARIDADE E DA COMPLEXIDADE}

A transdisciplinaridade, como o prefixo 'trans' aponta, está ao mesmo tempo entre, através e além das disciplinas. "Seu objetivo é a compreensão do mundo presente, para qual um dos imperativos é a unidade do conhecimento". (NICOLESCU, 1999, p. 53) 
Na visão da física clássica, não existe nada entre e através das disciplinas, considerando que cada fragmento do "big-bang disciplinar" é uma pirâmide inteira, e enxerga a transdisciplinaridade como absurdo por não ter um objeto. No entanto, a transdisciplinaridade não vê o pensamento clássico como absurdo, mas considera seu campo de aplicação como restrito. Nicolescu (1999) afirma que, diante dos vários níveis de realidade, o espaço entre e através das disciplinas está cheio.

Para o autor, a estrutura descontínua do espaço transdisciplinar é determinada pela estrutura descontínua dos níveis de realidade, o que demonstra a grande diferença entre a pesquisa transdisciplinar e a pesquisa disciplinar. Geralmente, a pesquisa disciplinar remete a um único nível de realidade, em contrapartida, a transdisciplinaridade se interessa pelo processo gerado pela ação de vários níveis de realidade ao mesmo tempo, mas a descoberta deste processo, inevitavelmente, percorre pelo conhecimento disciplinar, desta vez, de modo inovador e fecundo, o que não aconteceria somente pela metodologia disciplinar. Os dois tipos de pesquisas não são opostos e sim complementares.

A metodologia da transdisciplinaridade é determinada por três pilares, que são: os níveis de realidade; a lógica do terceiro incluído; e a complexidade; que de acordo com o nível de satisfação alcançado por cada pilar, produz diferentes graus de transdisciplinaridade.

No decorrer do século XX, concomitantemente ao surgimento dos diferentes níveis de Realidade e das novas lógicas (como a do terceiro incluído), dentro dos estudos naturais surge a complexidade. Ela se espalha rapidamente pelo mundo, tornando-se um desafio para nossa existência, pois, parece ter destruído o sentido em todos os campos do conhecimento.

Conforme aponta Nicolescu (1999), a complexidade se alimenta do crescimento disciplinar e acelera a multiplicação das disciplinas. A área de cada disciplina se torna cada vez mais estreita, tornando difícil, ou até impossível, a comunicação entre elas. Uma realidade complexa, aparentemente, substitui a realidade unidimensional simples do pensamento clássico. 0 indivíduo é bombardeado por uma quantidade cada vez maior de peças destacadas, estudadas pelas diferentes disciplinas. E isso reflete à uma tecnociência sem controle e sem valores, além da eficácia pela eficácia.

Complexus quer dizer o que foi tecido junto; Para Edgar Morin (2011), a complexidade existe quando diferentes elementos são inseparáveis e constituem um todo. E em nossa era global somos, cada vez mais, confrontados pelos desafios da complexidade.

Para Nicolescu, "na visão transdisciplinar, a pluralidade complexa e a unidade aberta são duas facetas de uma única e mesma Realidade" (NICOLESCU, 1999, p. 63). Explica que, este Princípio de Relatividade cria uma nova forma de olhar a cultura social, e que, quando nossa percepção de mundo muda, o mundo muda também. Os diferentes níveis de percepção possibilitam que o conhecimento humano acesse os diferentes níveis de Realidade, permitindo assim, uma visão cada vez mais geral, unificante, englobante da Realidade.

A visão transdisciplinar de Realidade tem consequências, principalmente no estudo da complexidade, em que seu lado contrário, a simplicidade, está se mostrando cada vez mais distante entre o ser humano e a Realidade. E desse modo, incorporando uma alienação autodestrutiva do ser humano e seu destino.

\section{CRISE MODERNA MULTIFORME E A FRAGMENTAÇÃO DO CONHECIMENTO}

Experimentamos uma crise pós-moderna e não sabemos ao certo suas origens. Segundo Nicolescu (1999), estamos expandindo os conhecimentos e atingindo níveis antes inimagináveis, porém, o acúmulo desse conhecimento e sua transmissão em forma de informações soltas e desvinculadas de seus contextos, não permite que as civilizações os integrem em seu interior. É irônico pensar que buscamos tanto conhecimento, mas nos tornamos reféns dele. Como explica Morin:

O conhecimento só é conhecimento enquanto organização, relacionado com as informações e inserido no contexto destas. As informações constituem parcelas dispersas de saber. Em toda parte, nas ciências como nas mídias, estamos afogados em informações. 0 especialista da disciplina mais restrita não chega sequer a tomar conhecimento das informações concernentes a sua área. Cada vez mais, a gigantesca proliferação de conhecimento escapa ao controle humano. (MORIN, 2014, pag. 15) 
Como disse Pascal (apud MORIN, 2014), "considero impossível conhecer as partes sem conhecer o todo, tanto quanto conhecer o todo sem conhecer, particularmente, as partes...”. Dessa forma, em concordância, Morin (2014) complementa que, o desafio da globalidade, é também, de complexidade. Realmente, há complexidade, quando as partes que formam o todo (como o econômico, o político, o psicológico, o afetivo, o sociológico, o mitológico) são indivisíveis e "existe um tecido interdependente, interativo, e interretroativo entre as partes e o todo, o todo e as partes". Assim sendo, frequentemente, estamos sendo confrontados com os desafios da complexidade e quanto mais a crise da modernidade avança, menor é a capacidade de refleti-la.

Apesar dos desenvolvimentos disciplinares das ciências serem vantajosos na divisão de trabalho, também trouxeram as desvantagens da superespecialização, do confinamento e do despedaçamento do saber.

Ao invés de repensar esses desenvolvimentos, nosso sistema de ensino tem sido conivente a eles. Como afirma Morin (2014):

Na escola primária nos ensinam a isolar os objetos (de seu meio ambiente), a separar as disciplinas (em vez de reconhecer suas correlações), a dissociar os problemas, em vez de reunir e integrar. Obrigam-nos a reduzir o complexo ao simples, isto é, a separar o que está ligado; a decompor, e não a recompor; e a eliminar tudo que causa desordens ou contradições em nosso entendimento. (MORIN, 2014, p. 15)

Portanto, de acordo com Morin (2014), concordamos que o conhecimento é algo indissociável da realidade do sujeito. E acrescentando, em conformidade com Araújo (2002), distanciar os sujeitos de sua realidade, desconecta a educação formal dos interesses e desejos dos alunos.

Retomando sobre a fragmentação do conhecimento em relação à transdisciplinaridade, continua, Nicolescu:

Aprendendo a conhecer também significa ser capaz de estabelecer as pontes entre as diferentes disciplinas e entre essas disciplinas e os significados e nossas habilidades interiores. Essa abordagem transdisciplinar será um complemento indispensável para a abordagem disciplinar, porque significa a emergência de seres continuamente conectados, capazes de adaptarem-se às exigências cambiantes da vida profissional e dotados de uma flexibilidade permanente sempre orientada na direção da atualização de suas potencialidades interiores. (NICOLESCU, 1997. Não Paginado.)

"A missão desse ensino é transmitir não o mero saber, mas uma cultura que permita compreender nossa condição e nos ajude a viver, e que favoreça, ao mesmo tempo, um modo de pensar aberto e livre". (Morin, 2014, p. 11). Ademais, Araújo (2002) acrescenta, defendendo a busca por uma educação em valores e de uma escola que tenha um ideal democrático de ensino, relacionando-se à vida das pessoas.

\section{A BASE NACIONAL COMUM CURRICULAR E SUA RELAÇÃO COM A EDUCAÇÃO INTEGRAL E O CURRÍCULO}

Em virtude da homologação da BNCC em dezembro de 2017, o Brasil passou a ter uma base com as aprendizagens previstas para toda a educação básica. E, conforme instituído pela LDB (Lei de Diretrizes e Bases da Educação Nacional) no 9.394/1996, deve orientar os currículos dos sistemas e redes de ensino das Unidades Federativas, assim como as propostas pedagógicas de todas as escolas públicas e privadas de educação básica no Brasil. Portanto, determina-se conhecimentos, competências e habilidades que todos os estudantes devem desenvolver ao decorrer da escolaridade básica. Guiada por princípios éticos, políticos e estéticos estabelecidos pelas Diretrizes Curriculares Nacionais da Educação Básica, a Base se une aos propósitos que a educação brasileira busca para a formação humana integral e o desenvolvimento de uma sociedade justa, democrática e inclusiva.

A BNCC deixa nítido seu compromisso com a Educação Integral e, evidencia que a Educação Básica deve buscar o pleno desenvolvimento humano, por meio de uma postura acolhedora e que respeite as singularidades e diversidades, sendo necessário a compreensão da complexidade e não linearidade desse processo, quebrando os antigos padrões reducionistas que privilegiava apenas a dimensão cognitiva. (BRASIL, 2018, p. 14) 
A Educação Integral da qual se trata na BNCC, não diz respeito à jornada escolar, mas sim, a ideia de criar processos educativos que proporcionem aprendizagens significativas que estejam associadas aos contextos, possibilidades e necessidades dos educandos, e também, aos desafios da atualidade. Deste modo, a BNCC coloca o educando no centro de suas aprendizagens, dando sentido ao que se aprende ao valorizar os seus contextos, possibilitando que eles possam ser aplicados na vida real. E para isso, coloca como parte fundamental a superação da fragmentação radical do conhecimento.

A BNCC e os currículos tem funções complementares, sendo que, as aprendizagens só acontecem por meio do conjunto de decisões que constituem o currículo utilizado. "São essas decisões que vão adequar as proposições da BNCC à realidade local, considerando a autonomia dos sistemas ou das redes de ensino e das instituições escolares, como também o contexto e as características dos alunos". (BRASIL, 2018, p. 16). Os sistemas e redes de ensino, bem como as escolas, são responsáveis por inserir aos currículos e as propostas pedagógicas a abordagem de temas da atualidade que interferem na vida humana, seja, local, regional ou global, de maneira transversal e integradora.

\section{RESULTADOS E DISCUSSÃO}

Ainda há muitas discussões e reflexões sobre o conteúdo da BNCC, especialmente, em relação as propostas para a educação integral, assim, fazendo-se fundamental que profissionais e estudiosos da área da educação busquem a apropriação e a compreensão do referido documento.

Certamente, a burocracia no sistema de ensino durante a implementação de uma mudança, torna tudo mais lento e gradual, e a própria BNCC, não dispõe de elementos e informações suficientes sobre como colocar em prática essa nova abordagem curricular. Isso têm gerado inseguranças e dúvidas aos educadores e gestores escolares quanto à sua efetiva aplicação.

Não resta dúvidas que a BNCC é um agente em potencial para a construção curricular como política de Educação Integral, já que ela apresenta em seu texto introdutório esta concepção. (WEFFORT, ANDRADE e DA COSTAS, 2019, p. 6). Foi estabelecido e garantido um currículo com uma nova concepção, integral e transversal, que propõe a superação da fragmentação do conhecimento, coloca o educando no centro de sua aprendizagem, valoriza a contextualização do que se aprende e visa desenvolver a capacidade de atender e resolver as demandas complexas da vida cotidiana. 0 que trouxe à tona antigas discussões sobre os temas transversais e não disciplinares.

Assim sendo, para "superar esta fragmentação, há diversas alternativas, como a pluridisciplinaridade, a interdisciplinaridade, a transdisciplinaridade, ou mesmo, a transversalidade, que prescinde da lógica disciplinar". (WEFFORT, ANDRADE e DA COSTAS, 2019, p. 90).

A transdisciplinaridade surge como uma proposta emergente, sendo citada direta e indiretamente na BNCC, e tem levado à recentes reflexões sobre o tema, mas ainda escassas no âmbito acadêmico. Ela se mostra como um promissor caminho para esse novo conceito de currículo transversal que visa o pleno desenvolvimento humano, pois, de acordo com Moraes (2015), sustentada por um olhar complexo da realidade como ação epistemológica, princípio e metodologia aberta de construção do conhecimento, tornase um instrumento capaz de garantir o lugar de interconexão disciplinar, de uma educação intercrítica e intercultural, alimentada por múltiplos olhares, linguagens, entendimentos e percepções da realidade que elimina o dogmatismo, o fundamentalismo e pensamento unívoco. Dessa forma, não só auxilia a compreender que o ser humano e suas várias dimensões fogem a qualquer recorte de caráter disciplinar, como também, que a educação como atitude transformadora das multidimensionalidades da vida, ocorre pela integração do que acontece nos diferentes níveis de materialidade do objeto, ou seja, de natureza física, biológica, social, cultural, psicológica e espiritual. A referida autora acredita que:

[...] uma metodologia transdisciplinar, pode se transformar em um fio condutor de uma nova proposta de educação que promova o encontro entre as perspectivas intercultural e intercrítica capazes de reconhecer, compreender e valorizar a diversidade humana, as relações culturais que nela se constituem e a necessária reciprocidade crítica, aspectos estes fundamentais para que possamos enfrentar os principais desafios vividos no mundo contemporâneo, bem como os diversos dilemas educacionais que tanto nos afligem. (MORAES, 2015, p. 31) 
Em consonância com a BNCC, em que "reconhecem que a educação tem um compromisso com a formação e o desenvolvimento humano global, em suas dimensões intelectual, física, afetiva, social, ética, moral e simbólica" (BRASIL, 2018, p.16), Moraes (2015) ressalta ainda que, também será preciso desenvolver o sujeito interior, resgatar o autoconhecimento e o reconhecimento do outro, a capacidade inerente do ser humano de auto-organização, autotransformação de sua consciência e renovação da própria vida.

A autora se refere a uma pedagogia transdisciplinar, em que o ser, o estar, o conhecer, o fazer, o sentir, o pensar e o agir estão unidos mutuamente. Que busca integrar "as dimensões corporais, psicológicas, sentimentais e espirituais do ser humano, com as dimensões sociais, econômicas, tecnológicas e culturais oferecidas pelo contexto em que se vive" (MORAES, 2015, p.21), porém, deixa claro que antes é preciso garantir uma educação de qualidade. Deste modo, Moraes conclui que:

Assim, necessitamos de uma educação integral disciplinar nutrida por novas visões conceituais capazes de promoverem um pensamento que não mais fragmenta, reduza ou dissocie a realidade. Uma nova proposta educacional que evite a dissonância cognitivo-afetiva, capaz de integrar pensamento e sentimento, educação e vida, teoria e prática docente. Uma educação que resgate o diálogo entre os elementos integrantes do triângulo da vida, constituídos pelas relações indivíduo/sociedade/natureza; que resgate e valorize a vida no seu sentido mais amplo, e em especial, a reconheça nos ambientes de ensino e aprendizagem. (MORAES, 2015, p.21)

Aqui, nota-se que a transdisciplinaridade não exclui os conhecimentos disciplinares e a sua função, mas sim, alimenta-se deles. De acordo com Moraes (2015), ela ocorre a partir desse conhecimento e vai além das fronteiras disciplinares, com uma abordagem diferenciada do conhecimento, da compreensão e situação de nossa própria existência. É fundamental assimilar que a atitude transdisciplinar possuí uma visão abrangente de que as coisas não são antagônicas, mas complementares. Resgatando assim, o caráter multidimensional do sujeito, com seus diversos níveis de percepção, como também, a multidimencionalidade da realidade, formada pelos diferentes níveis de materialidade do objeto.

Nesse aspecto, a educação transdisciplinar ressalta a importância de contextualizar o conhecimento, tal como previsto pela BNCC. Por isso, é preciso atender as necessidades reais e sentidas dos educandos como condição para compreender os níveis de realidade em que se encontram, indicados por seus devidos níveis de percepção. "Isso é assim porque sabemos que o que nos rodeia está inscrito dentro de cada um de nós, o que nos leva a perceber as implicações de nossas relações com a natureza, com a sociedade e com o sagrado presente em nosso interior". (MORAES, 2015, p. 100)

Com isso, percebe-se que o sujeito faz surgir o seu mundo conforme suas ações, como esclarece Moraes:

sendo sua atuação determinante e construtiva de seu domínio existencial, ou seja, do nível de realidade em que se encontra, assim como dos processos interativos que se apresentam e que o levam a encontrar ou não as possíveis soluções aos problemas emergentes. Meio, recursos e sujeitos estão entrelaçados, imbricados em uma rede de processos mútuos em situação de codeterminação, fazendo com que os processos de desenvolvimentos da consciência resultem, pois, de uma história tecida em conjunto, nascida de processos codeterminados, no quais sujeitos e mundos se influenciam mutuamente. (MORAES, 2015, p. 100)

Portanto, trabalha-se com o conceito de aprendizagem integrada, em que os fenômenos psíquicos e biofísicos são inseparáveis; não se prioriza o saber cognitivo em detrimento dos demais, pois, conforme Nicolescu (1997), entende-se que na construção do conhecimento transdisciplinar só se pode alcançar uma educação integral, se esta, for direcionada para a totalidade aberta do ser humano e não somente para um de seus componentes.

Entretanto, mesmo que a atualidade exija a formação integral e não fragmentada, o paradigma disciplinar da compartimentação do conhecimento continua hegemônico e predominante em nosso sistema educacional.

Portanto, a transdisciplinaridade se mostra como uma necessidade para esse enfrentamento, e apesar de já não ser uma utopia e ter seus fundamentos acadêmicos, ainda se mostra distante da prática pedagógica. Cordeiro (2019 apud MORAES 2010) destaca ainda que, a transdisciplinaridade não é uma nova crença ou teoria pedagógica que chega para sobrepor tudo o que foi alcançado em educação até hoje. 
Decerto, o maior desafio para a transdisciplinaridade se efetivar nas instituições de ensino hoje, é a formação docente. Nessa perspectiva, Cordeiro (2019) explana que:

espera-se que o Ministério da Educação (MEC), órgão federal responsável pela política nacional de educação, procure garantir aos profissionais do ensino esclarecimentos e orientações sobre o que são e como esses temas podem ser inseridos no contexto da Educação Básica de forma a contribuir com a construção de uma sociedade mais justa, igualitária e ética, e cumprir seu compromisso em promover uma educação integral assim como está previsto na própria BNCC. (CORDEIRO, 2019, p. 15)

Em contrapartida, ainda que as iniciativas oficiais sejam válidas, não podemos deixar a responsabilidade de importantes definições na área das políticas públicas e das práticas educacionais à cargo dos burocratas da educação. (CORDEIRO, 2019, p. 90 apud MORAES, 2010, p.291)

A BNCC deve ser devidamente reconhecida por sua finalidade, mas não obstante, a comunidade escolar e social deve reconhecer sua responsabilidade frente a educação e buscar na visão transdisciplinar, formas de mudar o paradigma educacional.

\section{CONSIDERAÇÕES FINAIS}

Entende-se, em conformidade com a BNCC que, a educação tem um compromisso com o desenvolvimento integral do educando. E que, de acordo com Moraes (2015), a metodologia transdisciplinar fomentada pela epistemologia da complexidade é capaz de apresentar as respostas necessárias para os iminentes desafios sociais, culturais, éticos e políticos de nossa época. Trata-se de uma pedagogia mais humana, que almeja criar uma consciência integral transdisciplinar e que busca uma educação que una as diversas dimensões da vida. Isto mostra que, uma educação significativa deve ser contextualizada e levar em consideração os diferentes contextos e percepções.

Sabemos que existe uma dificuldade em promover uma educação que remete à totalidade aberta do sujeito aprendente, que em sua maioria, trabalha-se somente com um de seus componentes. Por isso, não podemos permanecer assim, favorecendo a inteligência cognitiva em detrimento das demais, privilegiando o exterior sobre o interior.

Uma outra questão que tem prejudicado a renovação das atividades pedagógicas é a escassez de bases teóricas científicas durante a formação dos profissionais de educação, atrelado à dificuldade de repensar nosso próprio pensar. A formação docente enfrenta um obstáculo no que se refere a trabalhar as questões de natureza filosófica e epistemológica nas práticas pedagógicas, quando se trata de assegurar que a transdisciplinaridade e complexidade se transformem em efetivas propostas de atuação e intervenção no sistema educativo. Isso resultou em uma grande dificuldade para a mudança de paradigma educacional. (MORAES, 2015, p. 162).

É preciso enfatizar, ainda em conformidade com Cordeiro (2019), que a abordagem transdisciplinar não será a resolução de todos os problemas sociais e educacionais, entretanto, ela propõe aos educadores e aos envolvidos com a educação que, o conhecimento ocorra de forma reflexiva, baseada em um constante diálogo e mediada por um planejamento contextual e flexível fundamentado por um currículo que não deve ser limitado a grade curricular (sendo ela comum ou não) e nem fragmentado, mas sim, que seja aberto para outros saberes, em que o aprender para transformar a realidade seja tão importante quanto ensinar "as ciências".

Assumido esse compromisso com a formação integral, democrática e cidadã, que possibilita uma reforma de pensamento, entende-se que, todos têm uma responsabilidade social, coletiva e educacional. A comunidade escolar deve buscar meios de atuar com equidade, ética, solidariedade, respeito ao ser humano e ao pluralismo de culturas. (CORDEIRO, 2019, p. 88)

Deste modo, a transdisciplinaridade se mostra um caminho para uma ação educacional concreta, mas que só será possível para os que estiverem dispostos a transformar o modelo de ensino tradicional. Compreende-se que essa mudança será difícil, mas que isso, não exclui a legitimidade e eficácia dessa proposta, pois, um projeto não se mede somente pelo tempo que custa para o levar adiante e nem pelos esforços para o efetivar, muito menos pelos resultados. 
"Dá-se, sobretudo, pelo potencial de transformação pessoal e social que faz emergir o milagre de converter as dificuldades em possibilidades." (MORAES, 2015, p. 144) Por isso, acredita-se que os somos responsáveis e convidados à construir a educação transdisciplinar do futuro.

Ademais, anseio que debates e estudos mais profundos acerca dos problemas e soluções aqui propostos sejam analisados, e que seus desdobramentos, quando possível, sejam aplicados à prática pedagógica no sistema educacional do país.

Sei que ainda existe muito a ser explorado em relação a transdisciplinaridade, mas iniciei nesta pesquisa uma reflexão que espero dar continuidade em estudos e pesquisa de campo no futuro, para analisar as práticas docentes que incorporem noções da transdisciplinaridade como caminho para superar a hegemonia do cognitivo sobre a integralidade do humano.

\section{REFERÊNCIAS}

[1] ARAÚJO, Ulisses Ferreira de. A construção de escolas democráticas: histórias sobre complexidade, mudanças e resistências. São Paulo: Moderna, 2002.

[2] _ _ Temas transversais, pedagogia de projetos e as mudanças na educação. São Paulo: Summus, 2014.

[3] BRASIL. Ministério da Educação. Base Nacional Comum Curricular, versão final homologada em 2018. Disponível em: http://basenacionalcomum.mec.gov.br/images/BNCC_EI_EF_110518_versaofinal_site.pdf>. Acesso em 11 de junho 2020 .

[4] CORRÊA, Luiz Nilton. Metodologia Científica: Para trabalhos acadêmicos e artigos científicos. Florianópolis, SC: Do Autor, 2008.

[5] NICOLESCU, Basarab. Educação e transdisciplinaridade.

[6] GIL, Antônio Carlos. Como Elaborar Projetos de Pesquisa. 4. ed. São Paulo: Atlas, 2002.

[7] MORAES, Maria Cândida. Transdisciplinaridade, criatividade e educação: Fundamentos ontológicos e epistemológicos. Colaboração de Juan Miguel Batolloso Navas. Campinas, SP: Papirus, 2015. (Coleção Práxis)

[8] MORIN, Edgar, A cabeça bem-feita: repensar a reforma, reformar o pensamento/ Edgar Morin; tradução Eloá Jacobina. 21르 ed. Rio de Janeiro: Bertrand Brasil, 2014.

[9] MORIN, Edgar. Os sete saberes necessários à educação do futuro. Tradução de Catarina Eleonora F. da Silva e Jenne Sawaya; revisão técnica de Edgard de Assis Carvalho. - 2. Ed. Ver. - São Paulo: Cortez; Brasília, DF: UNESCO, 2011.

[10] CORDEIRO, Natália de Vasconcelos. Temas Contemporâneos e Transversais na BNCC: as contribuições da Transdisciplinaridade. 2019. 111 f. Dissertação de Mestrado em Educação. UCB, Brasília, 2019.

[11] NICOLESCU, A evolução transdisciplinar na universidade: condição para o desenvolvimento sustentável. In: Congresso Internacional A responsabilidade da Universidade para com a sociedade. Bankok, Thailand; 1997. (nov 12 14). Disponível em: <http://ciret-transdisciplinarity.org/bulletin/b12c8por.php>. Não paginado. Acesso em: $10 / 06 / 2018$

[12] _ _. _ Manifesto da Transdisciplinaridade. [Tradução: Lúcia Pereira de Souza]. São Paulo: TRIOM, 1999.

[13] SEVERINO, Antônio Joaquim, Metodologia do Trabalho Científico - 24 ed. Ver. E atual. - São Paulo: Cortez, 2016.

[14] WEFFORT, Helena F.; ANDRADE, Julia P.; DA COSTA, Natacha G. Currículo e educação integral na prática: uma referência para estados e municípios - 1. Ed. - São Paulo: Associação Cidade Escola Aprendiz, 2019. 


\title{
Capítulo 11
}

\section{As Ciências Humanas e a disciplina Geografia no contexto das políticas públicas educacionais atuais no Ensino Fundamental e Médio no Brasil}

\author{
Ana Cláudia Ramos Sacramento
}

Resumo: Nos últimos vinte anos, temos vivido diferentes reformas educacionais no mundo globalizado. Este tema vem sendo apresentado nas políticas públicas educacionais como uma forma de legitimar uma condição social e econômica importante para a reestruturação de currículos, avaliações, formações de todos os níveis, materiais didáticos e outros que afetam a estrutura das disciplinas ensinadas na escola básica. As Ciências Humanas têm sido desprestigiadas no Brasil - como em todo o mundo - principalmente, por agentes do Governo Federal ao alegarem ser um campo do conhecimento que não é aplicável ou não tem uma rentabilidade rápida ao mercado de trabalho. A Base Nacional Comum Curricular (BNCC) é um documento cujo princípio orientador é um projeto de nação, uma proposta de currículo, de sujeito, de aprendizagem e de sociedade que se quer constituir. Desde 2019, vem desempenhando efetivamente o papel regulador a Educação nacional. Traz o componente curricular Geografia no ensino fundamental, contudo - em relação ao ensino médio (2018) - está estruturada por áreas de conhecimento: Ciências Humanas e Sociais Aplicadas (Geografia, História, Filosofia e Sociologia) e suas habilidades nas quais as disciplinas não aparecem mais separadas. Desta forma, o objetivo deste trabalho é discorrer a respeito das mudanças que vem ocorrendo dentro das Ciências Humanas e em especial da disciplina Geografia no ensino fundamental e médio. Estas causam impactos na escola e na universidade tanto na prática docente como na estrutura das escolas, uma vez que os diferentes níveis de ensino em todo o país precisam adaptarem-se as novas políticas curriculares. Este estudo é derivado do projeto de pesquisa intitulado "As reformas nas Políticas Públicas Educacionais Brasileiras: o caso das Ciências Humanas e da disciplina Geografia na Formação de Professores", financiado pela FAPERJ por meio do Programa Jovem Cientista do Nosso Estado nos períodos de 2018 a 2021. A pesquisa possui como um dos objetivos avaliar os efeitos das reformas educacionais nacionais na disciplina Geografia no ensino fundamental e médio. A partir da metodologia qualitativa por meio da análise de discurso, podese realizar um estudo sobre a linguagem e a produção de sentidos para considerar a ideologia e a política nos textos construídos para pensar as suas finalidades e seus diferentes impactos. Como instrumento de pesquisa, utilizar-se-á o documento da Base Nacional Comum Curricular do Ensino Fundamental e Médio (2018) para compreender a presença da disciplina Geografia no contexto das Ciências Humanas. Assim, podemos questionar: Qual será o papel da Geografia frente as novas mudanças sugeridas nas políticas curriculares nacionais para z sociedade? Espera-se como resultado revelar a importância da Geografia para a sociedade ao mostrar sua relevância social na escola, uma vez que contribui para a reflexão da leitura e da do espaço geográfico nas diferentes escalas dos arranjos territoriais e das paisagens como uma forma de compreensão do mundo e dos fenômenos geográficos.

Palavras-chave: Políticas Públicas Educacionais. Geografia. BNCC. 


\section{INTRODUÇÃO}

As diferentes reformas educacionais ocorridas no mundo desde 1990 mostram a necessidade de refletir sobre como os países hibridizam a construção das suas políticas públicas educacionais e adaptam as condições socioeducacionais pré-existentes. Em especial, no Brasil, desde 2013; um conjunto de ações vem se realizando pelos diferentes governos para desenvolver a educação de base no país. Desta maneira, citamse o Plano Nacional de Educação (2014-2024), a Base Nacional Comum Curricular dos ensinos fundamental e Médio (2018), a Reforma do Ensino Médio (2017) e outros documentos criados para dar legitimidade as novas formas de pensar a educação nacional.

Estes documentos têm discursos propositivos para os Estados e Municípios organizarem seus textos curriculares na construção do conhecimento científico voltado a união dos entes federativos. Segundo o discurso presente na BNCC (2018), o objetivo é "superar a fragmentação das políticas educacionais, enseje o fortalecimento do regime de colaboração entre as três esferas de governo e seja balizadora da qualidade da educação" (p. 8). Esse argumento é recorrente em mudanças como "superação e fortalecimento", visto que a questão central da Educação não é sempre a tentativa de alinhar as políticas públicas em prol de uma educação igualitária, humana e acessível. Pode-se notar que todo pacote de reformas é vendido como sendo decorrente de um grande consenso nacional.

Desde 2018, concretizou-se a construção da Base Nacional Comum Curricular para a Educação Básica com as etapas de Ensinos Infantil, Fundamental e Médio, na qual o objetivo "define o conjunto orgânico e progressivo de aprendizagens essenciais que todos os alunos devem desenvolver ao longo das etapas e modalidades da Educação Básica" (BNCC, 2018, p.7). A necessidade de aprendizagem é outra prerrogativa sempre presente em documentos curriculares para estabelecer obrigações de transformações na concepção de ser o conhecimento escolar. Este conhecimento que está relacionado não mais a disciplina, mas em áreas do conhecimento e de componentes curriculares.

Neste texto, serão destacadas a área de conhecimento Ciências Humanas (Geografia e História) no Ensino Fundamental e área de Ciências Humanas e Sociais Aplicadas (Geografia, História, Filosofia e Sociologia), e suas habilidades no Ensino Médio na qual as disciplinas não aparecem mais separadas.

0 estudo deriva-se do projeto de pesquisa intitulado "As reformas nas Políticas Públicas Educacionais Brasileiras: o caso das Ciências Humanas e da disciplina Geografia na Formação de Professores", financiado pela FAPERJ através do Programa Jovem Cientista do Nosso Estado entre os períodos de 2018 a 2021. Apresenta um dos objetivos de avaliar os impactos das reformas educacionais nacionais na disciplina Geografia no ensino fundamental e médio.

Desta forma, reafirma-se que a finalidade deste trabalho, portanto, é discorrer a respeito das mudanças em Ciências Humanas e, especificamente, na disciplina de Geografia nos ensinos fundamental e médio.

Portela (2018) assim como Couto (2016) analisam a BNCC (2018) e comentam a urgência de uma reflexão sobre o significado das Ciências Humanas para pensar a relação com o componente curricular Geografia. A importância de considerar a Geografia para a formação dos estudantes está no fato de "ajudar o aluno a desenvolver, por meio de conteúdos, o pensamento geográfico que seja orientador das práticas espaciais cotidiana" (Cavalcanti, 2013, p. 47). Para tanto, discute-se, então, o propósito não do componente curricular, mas da disciplina na escola básica.

Para o desenvolvimento da pesquisa, busca-se através da metodologia qualitativa auxiliada pela análise de discurso um estudo sobre a linguagem e a produção de sentidos para considerar a ideologia e a política nos textos construídos, para pensar as suas finalidades e seus diferentes impactos. Como instrumento de pesquisa, utilizar-se-á o documento da Base Nacional Comum Curricular do Ensino Fundamental e Médio (2018) para compreender a presença da disciplina Geografia no contexto das Ciências Humanas.

0 texto está dividido em três momentos. 0 primeiro destaca as reformas nos últimos tempos no país, o segundo visar refletir como as Ciências Humanas estão articuladas na BNCC (2018) e no terceiro a concepção da disciplina Geografia sendo um competente curricular na BNCC (2018).

\section{REFORMAS EDUCATIVAS NO BRASIL E A RELAÇÃO COM A BNCC}

Nos últimos anos, temos vivenciado diferentes reformas educativas para comportar a urgência dos enquadramentos vinculados às formulações das leis vigentes no país desde 2013. Elas vêm sempre como salvadoras da pátria - como se fazer reformas fosse resolver todos os problemas da educação, como se não fosse uma questão estrutural e política de Estado. 
Em textos de Morais, Sacramento, Oliveira e Moraes (2018); e de Couto (2016); destacam as mudanças educacionais ocorridas no país desde a Constituição Federal, tratando de abordar sobre os diferentes impactos de políticas, leis e documentos curriculares na educação brasileira.

Essas leis trazem em suas redações discursos para implementação das ações a serem desenvolvidas para responder as metas. Sendo assim, atenta-se que a Lei no 12.796 de 2013 - que "altera a Lei no 9.394 de 20 de dezembro de 1996, que estabelece as diretrizes e bases da educação nacional para dispor sobre a formação dos profissionais da educação e dar outras providências" (BRASIL, 2013) - estabelece no artigo 26 que:

Os currículos do ensino fundamental e do ensino médio devem ter base nacional comum, a ser complementada, em cada sistema de ensino e em cada estabelecimento escolar, por uma parte diversificada, exigida pelas características regionais e locais da sociedade, da cultura, da economia e dos educandos. (BRASIL, 2013, s/p.)

A proposição do artigo citado é legitimar que Governo Federal estabeleça uma normativa na qual exista um documento base para a organização e sistematização dos currículos dos Estados e Municípios garantindo, assim, que nas redações dos documentos apareçam o texto da Base como definidor das concepções teóricometodológicas bem como pedagógica, respeitando as diversidades regionais de cada lugar. Lopes (2018, p. 23) destaca que:

Dentre eles podemos citar brevemente a insistência em um vínculo imediato entre educação e desenvolvimento econômico, a valorização do caráter salvacionista da educação (quase todos os problemas sociais são supostos como resolvidos com mais educação), a redução da educação a níveis de aprendizagem e ao fornecimento de garantias sociais de que todos os alunos e as alunas terão credenciais/padrões de aprendizado uniformes, a restrição da crítica teórica à BNCC ao registro ideológico (sob certo registro depreciativo da ideologia), a suposição de que os docentes não sabem o que fazer nas escolas sem uma orientação curricular comum.

Os discursos realizados por aqueles que propõem as mudanças são sempre como se as outras políticas precisassem ser destituídas em favor de uma nova pela necessidade de vincular à questão econômica. Sendo assim, concordamos com o argumento da autora. Os documentos, de maneira geral, padronizam os estudantes para um saber único, já que, ao ser implementados de fato, os estados e municípios seguem o geral.

Costa, Rodrigues e Stribel (2019) destacam que o documento mostra "ser o balizador de elementos decisivos na educação como na formação de professores, na avaliação e na elaboração de conteúdos educacionais" (p. 99). Desta maneira, eles ratificam a BNCC (2018) como o documento norteador das políticas educacionais e corroboram com as nossas preocupações a respeito do impacto do documento na política educacional brasileira.

A Lei 13.005 de 2014 - "a qual instituiu o Plano Nacional de Educação com vigência de 10 anos. São 20 metas para melhorar a qualidade da Educação Básica, sendo que quatro delas tratam da Base Nacional Comum Curricular" (BRASIL, 2014) apresenta a meta 2.2 que diz:

Pactuar entre União, estados, Distrito Federal e municípios, no âmbito da instância permanente de que trata o $§ 5^{\circ}$ do art. 7ํㅡ desta lei, a implantação dos direitos e objetivos de aprendizagem e desenvolvimento que configurarão a base nacional comum curricular do ensino fundamental. (BRASIL, 2014, s.p.)

0 discurso apresentado aponta a pactuação entre os entes para vigorar o documento da base nacional, a fim de que seja obrigatória sua articulação, bem como a organização e implementação em todos os níveis. Podese compreender os sentidos vinculados à idealização de uma proposta de implementação de um documento voltado para pensar a configuração da base e do desenvolvimento dos objetivos de aprendizagem. 
A Lei no 13.415 de 16/02/2017 “altera as Leis no 9.394. de 20 de dezembro de 1996, que estabelece as diretrizes e bases da educação nacional, e 11.494, de 20 de junho 2007, que regulamenta o Fundo de Manutenção e Desenvolvimento da Educação Básica e de Valorização dos Profissionais da Educação, a Consolidação das Leis do Trabalho - CLT, aprovada pelo Decreto-Lei no 5.452 , de 1o de maio de 1943, e o Decreto-Lei no 236, de 28 de fevereiro de 1967; revoga a Lei no 11.161, de 5 de agosto de 2005; e institui a Política de Fomento à Implementação de Escolas de Ensino Médio em Tempo Integral”: (BRASIL, 2017).

Art. 12. Os sistemas de ensino deverão estabelecer cronograma de implementação das alterações na Lei no 9.394, de 20 de dezembro de 1996,

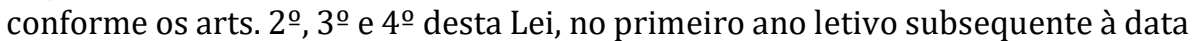
de publicação da Base Nacional Comum Curricular, e iniciar o processo de implementação, conforme o referido cronograma, a partir do segundo ano letivo subsequente à data de homologação da Base Nacional Comum Curricular. (BRASIL, 2017, s/p)

Neste artigo, as propostas já estão estabelecidas em relação à implementação da base entre os entes, após o período referido pelo documento. Desta forma, já mostra a obrigatoriedade do processo de realização pelos sistemas de ensino os ditos do documento.

Esses discursos destacam a relevância da BNCC (2018) para a construção de uma educação nacional. A prerrogativa está no próprio documento a seguir:

A Base Nacional Comum Curricular (BNCC) é um documento de caráter normativo que define o conjunto orgânico e progressivo de aprendizagens essenciais que todos os alunos devem desenvolver ao longo das etapas e modalidades da Educação Básica, de modo a que tenham assegurados seus direitos de aprendizagem e desenvolvimento, em conformidade com o que preceitua o Plano Nacional de Educação (PNE). (BNCC, 2018, p. 7)

A leitura inicial é que a BNCC é um documento dinâmico com o objetivo de pensar a construção de aprendizagens estruturantes para as diferentes esferas, para que se organize de forma linear as políticas públicas para sua execução de maneira uniforme.

a BNCC integra a política nacional da Educação Básica e vai contribuir para o alinhamento de outras políticas e ações, em âmbito federal, estadual e municipal, referentes à formação de professores, à avaliação, à elaboração de conteúdos educacionais e aos critérios para a oferta de infraestrutura adequada para 0 pleno desenvolvimento da educação. (BNCC, 2018, p. 8)

A BNCC tornou-se um documento no qual legitima uma lógica de pensar a educação por um viés voltado para os interesses atuais neoliberais dos governos vinculados à manutenção de uma lógica de individualista, cidadã consumista e de aprendizagem para o mercado de trabalho.

Cossio (2014) defende que a BNCC (2018) é um projeto de reeducação e manipulação da aprendizagem. Isto porque, para elas, o aluno que futuramente ingressará no mercado de trabalho tenha ao menos condições necessárias para exercer suas funções tem empresas que garantam uma mão de obra minimamente qualificada. Além disso, atentam que o aluno é educacionalmente formatado para tornar-se um cidadão que seja consumista, visto que o que é excluído e a margem da pobreza é considerado também como potencial consumidor.

\section{AS CIÊNCIAS HUMANAS NO CONTEXTO DA BNCC}

As Ciências Humanas aparecem nos documentos como área do conhecimento agregando os componentes curriculares (História e Geografia) no ensino fundamental e no ensino médio (História, Geografia, Filosofia e Sociologia). Couto (2016) atenta-se que essa divisão de áreas está, de acordo com a organização do ENEM, não tendo nenhum aspecto científico que situe epistemologicamente as ciências humanas ou naturais. Portela (2018) também corrobora com essa questão, ao buscar compreender como aparece o termo na ciência brasileira e mostrar que não há uma conotação teórica para essa classificação de Ciências Humanas. 
A BNCC (2018) referente ao ensino fundamental estabelece que a área traz contribuições aos estudantes em pensar as categorias e suas especificidades destacando as diferenças da diversidade humana. Desta forma,

A área de Ciências Humanas contribui, para que os alunos desenvolvam a cognição in situ, ou seja, sem prescindir da contextualização marcada pelas noções de tempo e espaço, conceitos fundamentais da área. Cognição e contexto são, assim, categorias elaboradas conjuntamente, em meio a circunstâncias históricas específicas, nas quais a diversidade humana deve ganhar especial destaque com vistas ao acolhimento da diferença. (BNCC, 2018, p. 353)

O discurso apresentado salienta que a cognição e o contexto sobre categoria - para ajudar a condição das circunstâncias históricas a qual aponta que os conceitos fundamentais da área - são tempo e espaço. Se discutirmos sobre a dimensão epistemológica, bem como sobre a história das duas disciplinas; vamos considerar que elas não têm o mesmo objeto. Assim, como juntar duas disciplinas que possuem características distintas, apesar da relação tempo-espaço?

Uma questão importante é a caracterização da Geografia e História como componentes curriculares, ou seja, a soma de conhecimentos e de disciplinas que ao final resultará em um produto ou serviço. Trabalhar o componente curricular faz-se necessário para a aplicação de conhecimentos (saber), habilidades (saber fazer) e atitudes (saber ser), isto é a competência. Destarte, o competente curricular não é disciplina e, sendo assim, os professores das outras áreas do conhecimento podem ensinar o componente. Este raciocínio didático-metodológico acontece em relação ao Ensino Médio, pois a organização da BNCC não tem os componentes curriculares, mas a área do conhecimento.

A importância da disciplina sendo matérias ensinadas aos alunos, normalmente referentes aos diferentes campos do conhecimento humano como a matemática, línguas, história, ciências entre outros. É buscar, a partir de sua epistemologia, produzir formas de conhecimento sobre a ciência. Em função disto, as disciplinas não trazem em si essa concepção pedagógica, por isso é mais interessante para a BNCC (2018) se trabalhar com competência.

Os conhecimentos específicos na área de Ciências Humanas exigem clareza na definição de um conjunto de objetos de conhecimento que favoreçam o desenvolvimento de habilidades e que aprimorem a capacidade de os alunos pensarem diferentes culturas e sociedades, em seus tempos históricos, territórios e paisagens (compreendendo melhor o Brasil, sua diversidade regional e territorial). E também que os levem a refletir sobre sua inserção singular e responsável na história da sua família, comunidade, nação e mundo (BNCC, 2018, p. 354).

Nessa discussão, os autores apontam para o desejo de ponderar acerca dos objetos de conhecimento e da aprendizagem escolar, quando consideram Geografia e História como componentes. Podem dizer que o conhecimento seria uma soma de coisas e pode ser ensinado sem levar em consideração muitos aspectos da própria ciência de origem. Assim, destacamos a explicação de Couto (2016, p. 191)

A linguagem é inerente ao fazer científico: todas as ciências constituem-se através de e se materializam em linguagens. A geografia nunca se encaixou perfeitamente nas ciências humanas e nem nas ciências naturais, pois aborda temas humanos e naturais, por força da filosofia neo-kantiana na virada do século XIX para o XX. Da mesma forma, o ser humano pode ser interpretado como um sujeito-objeto de estudo da história natural e, simultaneamente, social.

Concordamos com a ideia proposta por Couto (2016) ao afirmar que é difícil dimensionar a geografia para ciências humanas ou naturais, posto que discorre em sua epistemologia a relação sociedade e natureza. Os elementos físico-naturais são partes da discussão da produção do espaço, com isso, possibilitando a geografia ter uma linguagem única. 
Em relação ao Ensino Médio, podemos observar a Resolução no 4 de 17 de dezembro de 2018 (*) que "Institui a Base Nacional Comum Curricular na Etapa do Ensino Médio (BNCC-EM), como etapa final da Educação Básica, nos termos do artigo 35 da LDB, completando o conjunto constituído pela BNCC da Educação Infantil e do Ensino Fundamental com base na Resolução CNE/CP no 2/2017 fundamentada no Parecer CNE/CP no 15/2017”. BRASIL, 2018). Estabelece que o ensino médio será organizado por áreas do conhecimento.

Art. 10. A formação geral básica tem a BNCC-EM como referência obrigatória, sendo composta pelas previstas competências e habilidades, articuladas como um todo indissociável, e enriquecidas pelo contexto histórico, econômico, social, ambiental, cultural, local, do mundo do trabalho e da prática social deverá ser organizada nas seguintes Áreas do Conhecimento: I - Linguagens e suas tecnologias; II - Matemática e suas tecnologias; III - Ciências da natureza e suas tecnologias; IV - Ciências humanas e sociais aplicadas. (BRASIL, 2018, p.6)

Desta maneira, o documento explicita a divisão do ensino médio somente por área de conhecimento estando os componentes curriculares diluídos nelas.

A BNCC da área de Ciências Humanas e Sociais Aplicadas - integrada por Filosofia, Geografia, História e Sociologia - propõe a ampliação e o aprofundamento das aprendizagens essenciais desenvolvidas no Ensino Fundamental, sempre orientada para uma formação ética. Tal compromisso educativo tem como base as ideias de justiça, solidariedade, autonomia, liberdade de pensamento e de escolha, ou seja, a compreensão e o reconhecimento das diferenças, o respeito aos direitos humanos e à interculturalidade, e o combate aos preconceitos de qualquer natureza (BNCC, 2018, p. 561).

Os componentes curriculares não consideram as especificidades das ciências em si, mas buscam conceitos e categorias que possam ter um diálogo entre os componentes que estão agregados na área do conhecimento. No próprio trecho tratado, propõe aprofundamento de aprendizagens, contudo, terão "habilidades" consideradas essenciais à Geografia que não serão tratadas no ensino médio, principalmente, às ligadas aos componentes físico-naturais tão necessárias para a construção do conhecimento geográfico.

Considerando as aprendizagens a ser garantidas aos jovens no Ensino Médio, a BNCC da área de Ciências Humanas e Sociais Aplicadas está organizada de modo a tematizar e problematizar algumas categorias da área, fundamentais à formação dos estudantes: Tempo e Espaço; Territórios e Fronteiras; Indivíduo, Natureza, Sociedade, Cultura e Ética; e Política e Trabalho. Cada uma delas pode ser desdobrada em outras ou ainda analisada à luz das especificidades de cada região brasileira, de seu território, da sua história e da sua cultura (BNCC, 2018, p. 562)

As categorias que versam os componentes curriculares desta área buscam orientar a formação dos estudantes. Aparentemente, elas estão imbricadas na dinâmica conceitual mais geral da área e atenta-se para trabalhar a diversidade regional do país.

Uma questão relevante é notar a relação entre Tempo e Espaço como categorias escolhidas para explicar os fenômenos na área, ou seja, permeia o processo de construção do conhecimento no ensino médio.

Tempo e Espaço explicam os fenômenos nas Ciências Humanas, porque permitem identificar contextos, sendo categorias difíceis de se dissociar. No Ensino Médio, a análise de acontecimentos ocorridos em circunstâncias variadas torna possível compará-los, observar suas semelhanças e diferenças, assim como compreender processos marcados pela continuidade, por mudanças e por rupturas (BNCC, 2018, p. 563)

Destaca-se que na explicação o contexto histórico é dado mais ênfase como forma de mostrar a complexidade do conhecimento a ser ensinado por quatro componentes curriculares que tem objetos distintos: a Geografia - o espaço, a História - o tempo, a Sociologia - os problemas sociais e a Filosofia - o conhecimento. Desta forma, como buscar uma epistemologia única para um conjunto de saberes complexos, com diferentes métodos e epistemologias, tendo em comum a sociedade? 


\section{A DISCIPLINA GEOGRAFIA NO CONTEXTO DA BNCC}

Alguns autores têm se debruçado a compreender a disciplina Geografia na BNCC (2018). Couto (2016), Pinheiro e Lopes (2017), Portela (2018), Costa, Rodrigues e Stribel (2019) são alguns exemplos de autores empenhados na discussão sobre a importância dessa disciplina e suas implicações teóricas. Entende-se que análises se tornam necessárias para as leituras críticas sobre o significado da Geografia neste contexto.

À vista disto, o presente estudo não procura debater se o documento é essencial ou não, pois ele é uma realidade recorrente nas escolas brasileiras, mas possibilitar entender o alinhamento entre os documentos vigentes no país e refletir sobre o impacto dentro da Geografia. Como não é mais uma disciplina e, sim, um componente curricular que vigora no discurso do documento. Entende-se também que há um limite de escrita e há uma escolha sobre o tratamento a ser realizado durante o texto.

A BNCC (2018) do ensino fundamental estabelece a organização do proponente por meio do componente curricular. Vale a pena mencionar novamente que neste trabalho que não se considera "componente" e "disciplina" como conceitos didáticos equivalentes.

Estudar Geografia é uma oportunidade para compreender o mundo em que se vive, na medida em-que esse componente curricular aborda as ações humanas construídas nas distintas sociedades existentes nas diversas regiões do planeta. (BNCC, 2018, p. 359).

Então, tratamos a Geografia como disciplina, pois tem uma epistemologia, um método e uma história dentro da ciência com suas especificidades necessárias para pensá-la no sentido de ajudar a "formar um tipo de raciocínio, para que o aluno aprenda a se relacionar com o mundo como objeto de pensamento" (CAVALCANTI, 2013, p. 58).

O documento constitui-se de elementos para destacar a relevância da Geografia; a partir da categorização de algumas características como pensamento espacial, raciocínio geográfico, situação geográfica. São partes dos componentes da ciência e dão legitimidade a construção geográfica como o caso dos conceitos. Diante disto, pode-se analisar que

a BNCC está organizada com base nos principais conceitos da Geografia contemporânea, diferenciados por níveis de complexidade. Embora o espaço seja o conceito mais amplo e complexo da Geografia, é necessário que os alunos dominem outros conceitos mais operacionais e que expressam aspectos diferentes do espaço geográfico: território, lugar, região, natureza e paisagem. (BNCC, 2018, p. 361)

Os autores argumentam a organização dos conceitos-chaves trabalhados dentro da Geografia que são estruturantes dentro da ciência e que potencializam o conhecimento geográfico escolar. Há concordância com o documento, levando em consideração o que Haesbaert (2011) destacou sobre a importância desses conceitos: região, território, lugar e paisagem como constelação conceitual da categoria-chave espaço geográfico. Contudo, os autores se limitaram nas citações dos conceitos sem um aprofundamento em questão.

Ao discorrer sobre a dimensão pedagógica, os autores ratificam a divisão por unidades temáticas e habilidades: "Para dar conta desse desafio, o componente Geografia da BNCC foi dividido em cinco unidades temáticas comuns ao longo do Ensino Fundamental em uma progressão das habilidades" (BNCC, 2018, p. 361). As implicações na organização do documento de Ciências Humanas - Geografia mostram os impactos na articulação da produção do conhecimento geográfico na escola básica. Concordamos, deste modo, com Costa, Rodrigues e Stribel (2019, p. 102) ao discorrerem que:

Desenvolver um olhar geográfico, a partir de conceitos, é defendido, então, com um objetivo da Geografia escolar que, embora, repouse na objetividade dos conceitos, projeta a subjetividade no olhar individual dos sujeitos envolvidos com a e na educação em Geografia. Não se trata, portanto, de uma disciplina que busque o pragmatismo no desenvolvimento de habilidades ou de um saber fazer pautado na expectativa de transmissão de conteúdos. 
Os autores evidenciam outro fato relevante. Se a dimensão é pensar, a partir dos conceitos geográficos, por meio do pensamento espacial e raciocínio geográfico; existe, por assim dizer, uma contradição em querer estabelecer as competências e as habilidades para construir o conhecimento geográfico em si. Desta maneira, as implicações estão no tratamento à dimensão atribuída ao ensinar Geografia que está para além de habilidades e, sim, "ajudar os alunos a desenvolver esse olhar geográfico e apreenderem a construir explicações para a espacialidade que é experimentada, que é vivida cotidianamente por eles" (CAVALCANTI, 2013, pp. 58).

Em relação ao ensino médio, não existe mais a separação dos componentes curriculares. Então, as competências e aprendizagens estão articuladas na área.

Considerando as aprendizagens a ser garantidas aos jovens no Ensino Médio, a BNCC da área de Ciências Humanas e Sociais Aplicadas está organizada de modo a tematizar e problematizar algumas categorias da área, fundamentais à formação dos estudantes: Tempo e Espaço; Territórios e Fronteiras; Indivíduo, Natureza, Sociedade, Cultura e Ética; e Política e Trabalho. Cada uma delas pode ser desdobrada em outras ou ainda analisada à luz das especificidades de cada região brasileira, de seu território, da sua história e da sua cultura. (BNCC, 2018, p. 562)

Observa-se a tentativa de organizar a área por conceitos que os autores caracterizam como problematizadores dentro dos componentes curriculares em questão. Do ponto de vista macro, pode-se dizer que são conceitos estruturantes para compreender determinados aspectos do conhecimento dos componentes curriculares em si. Mas, ao se debruçar na leitura mais detalhada de como esses conceitos são desenvolvidos, não existe de fato uma epistemologia clara desses conceitos.

Caracterizar que existe os conceitos de Espaço, Território, Fronteira, Natureza, Trabalho comumente vistos na Geografia não garantem que haverá um diálogo com conteúdo de fato a pensá-la, uma vez que alguns destes conceitos estão muito genéricos. Entretanto, há alguns conceitos que se aproximam das discussões realizadas na Geografia. Ao tratar sobre o espaço, os autores buscam trazer que:

A compreensão do espaço deve contemplar suas dimensões histórica e cultural, ultrapassando suas representações cartográficas. Espaço está associado aos arranjos dos objetos de diversas naturezas e, também, às movimentações de diferentes grupos, povos e sociedades, nas quais ocorrem eventos, disputas, conflitos, ocupações (ordenadas ou desordenadas) ou dominações. No espaço (em um lugar), se dá a produção, a distribuição e o consumo de mercadorias. Nele, são realizados fluxos de diversas naturezas (pessoas e objetos) e são desenvolvidas relações de trabalho, com ritmos e velocidades variados. (BNCC, 2018, p. 563)

O estudo retrata que o espaço é categoria com dimensões históricas e com seus arranjos de objetos tanto naturais como humanos constituindo assim formas de pensar a geografia, além das funções que são estabelecidas deste espaço. Pode-se explicar, a partir da categoria de Território, que a discussão teórica já está vinculada a uma condição tradicional do seu uso, para que possa abarcar os outros componentes curriculares. Este mais relacionado ao território solo, ou seja, espaço limite delimitado, pouco usado atual.

Território é uma categoria usualmente associada a uma porção da superfície terrestre sob domínio de um grupo e suporte para nações, estados, países. É dele que provêm alimento, segurança, identidade e refúgio. Engloba as noções de lugar, região, fronteira e, especialmente, os limites políticos e administrativos de cidades, estados e países, sendo, portanto, esquemas abstratos de organização da realidade. Associa-se território também à ideia de poder, jurisdição, administração e soberania, dimensões que expressam a diversidade das relações sociais e permitem juízos analíticos. (BNCC, 2018, p. 564)

Destarte, observa-se a necessidade de adequação deste conceito para a área. Limitou-o a uma discussão tradicional, mesmo com a associação à ideia de poder, mas a ideia geral é do território fixo. Isso acontece com as outras categorias o que enfraquece do ponto de vista conceitual os diferentes objetos estudados das disciplinas específicas do conhecimento. 


\section{CONCLUSÃO}

O discurso trazido pelos documentos apresentados busca trazer a BNCC (2018) como um elemento essencial na transformação da educação brasileira e propõem formas de condução das Ciências Humanas e da disciplina Geografia que nos fazem refletir sobre o seu papel frente essas mudanças.

Entende-se que a BNCC (2018) é um documento com base em competências e habilidades, organizado em áreas do conhecimento; a partir dos componentes curriculares e tem a função de nortear as aprendizagens nos diferentes estados e municípios.

Desta maneira, a área de Ciências Humanas trazida por Couto (2016) e Portela (2018) não representa uma área científica em si, com um conjunto de conceitos e conteúdos organizados. Além disso, não defendemos o componente curricular, pois não é sinônimo de disciplina e, sim, uma soma de conhecimento sem fundamento conceitual histórico.

Assim, vê-se uma Geografia não disciplinar na BNCC (2018), mas componente que busca por meio de elementos em comum da ciência geográfica estabelecer um conjunto de elementos que a justifique como tal desconsiderando toda uma história no campo disciplinar. Logo, concordamos com Lopes $(2018$, p. 27)

uma base curricular comum, tal como organizada no país, pressupõe apostar em um registro estabelecido como tendo um selo oficial de verdade, um conjunto de conteúdos que adquire o poder de conhecimento essencial a ser ensinado e aprendido, metas uniformes e projetos identitários fixos, trajetórias de vida preconcebidas, esforços para conter a tradução e impor uma leitura como a correta, única e obrigatória.

Compreendemos que existem outras formas de pensar as Ciências Humanas e a Geografia para além do que estar descrito no documento, não sendo só ele quem tem a verdade e o elemento essencial de ensino e de aprendizagem, pois temos desigualdades e diferenças no âmbito escolar e social, como também de ensino em suas diferentes escalas.

Portanto, destacamos que a importância de ensino de geografia disciplinar que busca conceber um pensamento geográfico que seja orientador de práticas socioespaciais dos estudantes constituídos não só nos discursos presentes nos documentos, como também nas dinâmicas das relações socioespaciais e educativas das diferentes escolas.

\section{REFERÊNCIAS}

[1] BRASIL. Presidência da República. Casa Civil. Lei no 12.796, de 4 de abril de 2013 - Altera a Lei no 9.394, de 20 de dezembro de 1996, que estabelece as diretrizes e bases da educação nacional, para dispor sobre a formação dos profissionais da educação e dar outras providências. Diário Oficial da União. Brasília, DF, 2013. Disponível em:http://www.planalto.gov.br/ccivil_03/_ato2011-2014/2013/lei/112796.htm. Acesso em: 26 abr. 2020.

[2] BRASIL. Lei 13.005 de 25 de junho de 2014. Aprova o Plano Nacional de Educação -PNE e dá outras providências. Diário Oficial da União. Brasília, DF, 2014. Disponível em https://www.jusbrasil.com.br/diarios/72231507/dou-edicao-extra-secao-1-26-06-2014-pg-1 Acesso em: 26 abr. 2020.

[3] BRASIL. Lei no 13.415, de 16 de fevereiro de 2017. Altera as Leis noㅇ 9.394, de 20 de dezembro de 1996, que estabelece as diretrizes e bases da educação nacional, e 11.494, de 20 de junho 2007, que regulamenta o Fundo de Manutenção e Desenvolvimento da Educação Básica e de Valorização dos Profissionais da Educação, a Consolidação das Leis do Trabalho - CLT, aprovada pelo Decreto-Lei no 5.452, de 1o de maio de 1943, e o Decreto-Lei no 236, de 28 de fevereiro de 1967; revoga a Lei no 11.161, de 5 de agosto de 2005; e institui a Política de Fomento à Implementação de Escolas de Ensino Médio em Tempo Integral. Diário Oficial da União. Brasília, DF, 2017. Disponível em http://www2.camara.leg.br/legin/fed/lei/2017/lei-13415-16-fevereiro-2017-784336-publicacaooriginal-152003pl.html.Acesso em: 26 abr. 2020.

[4] BRASIL. Resolução no 4, de 17 de dezembro de 2018 (*). Institui a Base Nacional Comum Curricular na Etapa do Ensino Médio (BNCC-EM), como etapa final da Educação Básica, nos termos do artigo 35 da LDB, completando o conjunto constituído pela BNCC da Educação Infantil e do Ensino Fundamental, com base na Resolução CNE/CP no 2/2017, fundamentada no Parecer CNE/CP no 15/2017. Diário Oficial da União. Brasília, DF, 2018. Disponível em http://portal.mec.gov.br/docman/dezembro-2018-pdf/104101-rcp004-18/file. Acesso em: 26 abr. 2020.

[5] BRASIL. Base Nacional Comum Curricular. Brasília: MEC, 2018. Disponível em:http://basenacionalcomum.mec.gov.br/images/BNCC_EI_EF_110518_versaofinal_site.pdf Acesso em: 26 abr. 2020. 
[6] CAVALCANTI, Lana de Souza. Geografia escolar e a busca de abordagens teórico/práticas para realizar sua relevância social. In: SILVA, Eunice Isaías da; PIRES, Lucineide Mendes. Desafios da didática de geografia. Goiânia: Ed. da PUC Goiás. 2013, p. 45-68.

[7] COSSIO, Maria de Fátima. Base Comum Nacional: uma discussão para além do currículo. São Paulo: Revista eCurriculum, v. 12 n. 3, out./dez, 1570-1590p., 2014. (Programa de Pós-graduação Educação: Currículo - PUC/SP). Disponível em https://revistas.pucsp.br/index.php/curriculum/article/view/21669. Acesso em: 29 abr. 2020.

[8] COSTA, Hugo Heleno Camilo; RODRIGUES, Phelipe Florez; STRIBEL, Guilherme Pereira. Teoria Curricular e Geografia: convites à reflexão sobre a BNCC. Revista Brasileira de Educação em Geografia, Campinas, v.9, n. 17, 86-108p., jan./jun. Disponível em http://www.revistaedugeo.com.br/ojs/index.php/revistaedugeo/article/view/578. Acesso em: 29 abr. 2020.

[9] COUTO, Marcos Antônio Campos. Base Nacional Comum Curricular - BNCC Componente curricular: Geografia. Revista da ANPEGE, v. 12, n. 19, 183-203p., 2016. Disponível em: http://ojs.ufgd.edu.br/index.php/anpege/article/view/6379. Acesso em: 29 abr. 2020.

[10] HAESBAERT , Rogério. Espaço como categoria e sua constelação de conceitos: uma abordagem. In: TONINI, Ivaine Maria et al. 0 ensino de geografia e suas composições curriculares. 2011, p. 109-120.

[11] LOPES, Alice Casimiro. Apostando na produção contextual do currículo. In AGUIAR, Márcia Angela da S.; DOURADO, Luiz Fernando. A BNCC na contramão do PNE 2014-2024: avaliação e perspectivas. [Livro Eletrônico]. Recife: ANPAE. p. 23-33, 2018. http://www.anpae.org.br/BibliotecaVirtual/4-Publicacoes/BNCC-VERSAO-FINAL.pdf

[12] MORAIS, Eliana Marta Barbosa et. al. Os documentos curriculares nacionais: A reforma do ensino médio e a disciplina Geografia. In: IX Fórum Nacional NEPEG de Formação de professores. Caldas Novas. Anais... Caldas Novas: NEPEG, 2018, p. 520-530.

[13] PINHEIRO, Isadora; LOPES, Claudivan Sanches. Reflexões sobre a Geografia na Base Nacional Comum Curricular (BNCC). In: X Encontro Internacional de Produção Científica. UniCesumar. Maringá. Anais.... Maringá: X EPCC,2017, s/p. Disponível em: https://proceedings.science/epcc/papers/reflexoes-sobre-a-geografia-na-basenacional-comum-curricular- $\% 28 \mathrm{bncc} \% 29$

[14] PORTELA, Mugiany Oliveira Brito. A BNCC para o ensino de Geografia: A proposta das Ciências Humanas e da Interdisciplinaridade. OKARA: Geografia em debate (UFPB), v.12, n. 1, 48-68p. 2018.Disponível em: https://periodicos.ufpb.br/ojs2/index.php/okara/article/view/38216. Acesso em: 29 abr. 2020. 


\section{Capítulo 12}

Projeto "Departures - de Ponta Grossa para o mundo!": Sintetizando dois anos de realizações

\section{Juvancir da Silva}

\section{Eugênio Maurício da Silva Neto}

Janaina Rodrigues de Almeida

\section{Carolina Scalise Taques Fonseca Schlumberger}

Resumo: 0 projeto Departures - de Ponta Grossa para o mundo! desenvolve e promove ações visando contribuir para a internacionalização do curso de Administração da Universidade Estadual de Ponta Grossa, especificamente no que diz respeito ao processo denominado Internationalization at Home ( $\mathrm{IaH}) .0$ presente artigo objetiva apresentar, sintetizada e retrospectivamente, as ações e as conquistas do projeto, durante os dois primeiros anos desde seu protocolo inicial, ou seja, no período de 2018 a 2020. Assim, menciona o Fórum de Mobilidade, as palestras de lançamento do Fórum de internacionalização, o II fórum de internacionalização, os eventos em língua inglesa "Let's talk about..." e a participação em eventos locais, regionais, nacionais e internacionais.

Palavras-chave: Internacionalização acadêmica. Empreendedorismo. Mobilidade acadêmica. 


\section{INTRODUÇÃO}

O projeto tratado no presente trabalho intitula-se "Departures - de Ponta Grossa para o mundo!" e faz parte do Programa de Internacionalização, Trabalho e Empreendedorismo (PRINTe), do curso de Administração, da Universidade Estadual de Ponta Grossa. As ações extensionistas do presente projeto destinam-se a docentes, discentes e funcionários da Universidade Estadual de Ponta Grossa (UEPG). Além disso, impactam a comunidade empresarial da cidade de Ponta Grossa e a comunidade acadêmica da cidade e da região dos Campos Gerais.

Os municípios atingidos por meio das ações extensionistas desse projeto são Ponta Grossa e todos os municípios da região dos Campos Gerais. As ações são realizadas no campus central da UEPG, em Ponta Grossa, Paraná.

\subsection{JUSTIFICATIVA}

0 projeto Departures se justifica pela necessidade de internacionalização que permeia o curso de Administração. Partiu-se do princípio de que o projeto pedagógico destaca a importância de atividades interdisciplinares que possibilitem a inserção do aluno na sociedade onde vive e, também, da importância do desenvolvimento de estratégias de internacionalização destacadas pelo PDI (Plano de Desenvolvimento Institucional) da UEPG.

As atividades desenvolvidas no contexto do projeto Departures visam proporcionar a reflexão sobre a importância da internacionalização para cada indivíduo, apontar os caminhos para a internacionalização a partir de ações internas (como a curricularização da internacionalização, por exemplo) e facilitar e promover o contato com pessoas de outras culturas, por meio de ações da chamada Internationalization at Home (IaH).

\subsection{OBJETIVOS}

O objetivo geral do projeto Departures é contribuir para a promoção da internacionalização do Curso de Administração da UEPG e, para atingí-lo, foram definidos os seguintes objetivos específicos:

I. Resgatar e apresentar experiências de mobilidade discente e docente;

II. Identificar facilidades e dificuldades a partir das experiências resgatadas;

III. Apresentar possibilidades de mobilidade dentro da UEPG;

IV. Despertar o interesse pela curricularização da internacionalização;

V. Fornecer ferramentas e informações para a atividade profissional internacionalizada;

VI. Refletir sobre a experiência internacional.

\section{METODOLOGIA}

Durante os dois anos de existência do projeto Departures, foram realizados dois Fóruns próprios (2018 e 2019), um evento de lançamento com duas palestras (2019), uma Live em rede social (2020). Foram realizadas quatro reuniões, denominadas "Let's talk about..." em que executivos estrangeiros, de organizações multinacionais ou com atuação internacional, conversaram em inglês, com alunos e professores do curso de Administração, sobre as mais diversas áreas do conhecimento administrativo.

A equipe do Departures foi convidada a promover e coordenar uma mesa redonda no ADM 2019 Congresso Internacional de Administração e outra, por meio de uma Live no ADM 2020 - Congresso Internacional de Administração.

Finalmente, graças a esse projeto, foram produzidos dois trabalhos para eventos internacionais (2019), um trabalho para evento nacional (2020), um trabalho para evento regional (2019) e quatro trabalhos para evento local (2019 e 2020). Além disso, a coordenação do projeto realizou visita técnica a duas Universidades norte-americanas (University of Central Florida e Valencia College), a fim de estabelecer parcerias que já começaram a ser delineadas e só não evoluíram mais por conta da pandemia do Covid-19. 


\section{RESULTADOS}

A primeira atividade do Projeto Departures foi o Fórum de Mobilidade Acadêmica (Figura 1), realizado no dia 30 de novembro de 2018. Nessa ocasião, docentes e discentes apresentaram suas experiências internacionais. Discutiu-se sobre facilidade e dificuldades enfrentadas no processo de mobilidade, bem como sobre os principais resultados e benefícios. Foram apresentadas experiências internacionais na Bolívia, na Irlanda, nos Estados Unidos e no México.

Figura 1 - Fórum de Mobilidade Acadêmica - equipe de discentes voluntários da organização.

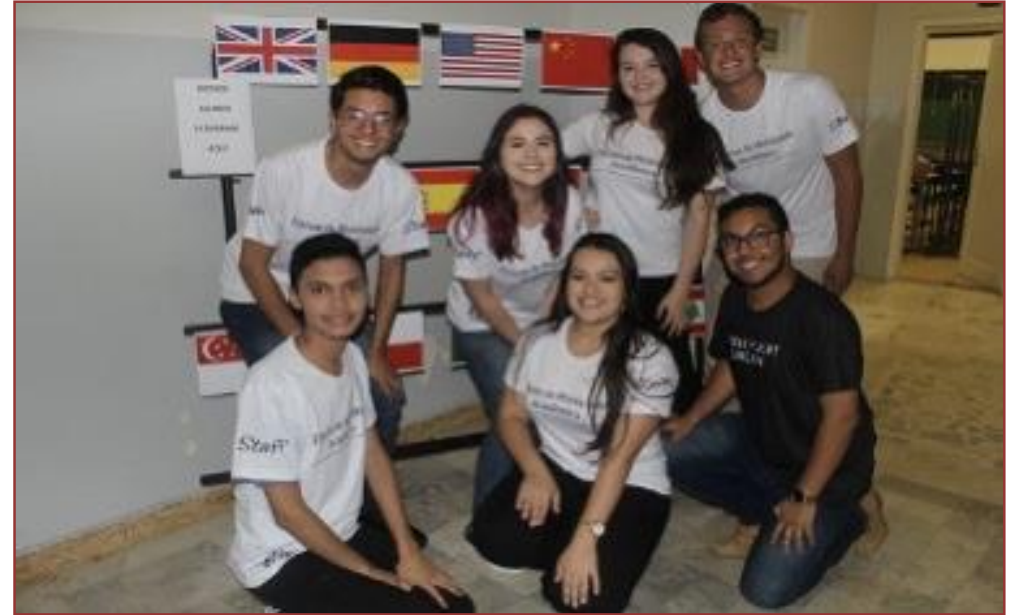

Legenda: Alunos do curso de ADM/Comércio Exterior, voluntários do projeto, 2018.

A equipe do Escritório de Relações Internacionais (ERI) da UEPG explicou os procedimentos para a realização da mobilidade a partir das normas internas da UEPG. 0 relato sobre esse fórum aconteceu em forma de resumo/apresentação oral, no evento internacional da Brazilian Association for International Education (FAUBAI 2019 Conference). Um trabalho apresentado no 17ํㅡㄹ Conex/ 2ํㅡㄹ EAEX apresentou todos os detalhes referentes ao formato e aos resultados do referido Fórum.

No ano de 2019, foi realizado o Lançamento do II Fórum de Internacionalização (Figura 2) , no dia 21 de março de 2019, com duas palestras: a primeira abordou os requisitos, critérios e procedimentos para a mobilidade acadêmica direcionada aos EUA e, a segunda, foi apresentada por um empresário e ex-executivo de uma multinacional européia, que discutiu as dificuldades e os aprendizados de quem realiza mobilidade no contexto profissional.

Figura 2 - Lançamento do Fórum de Internacionalização

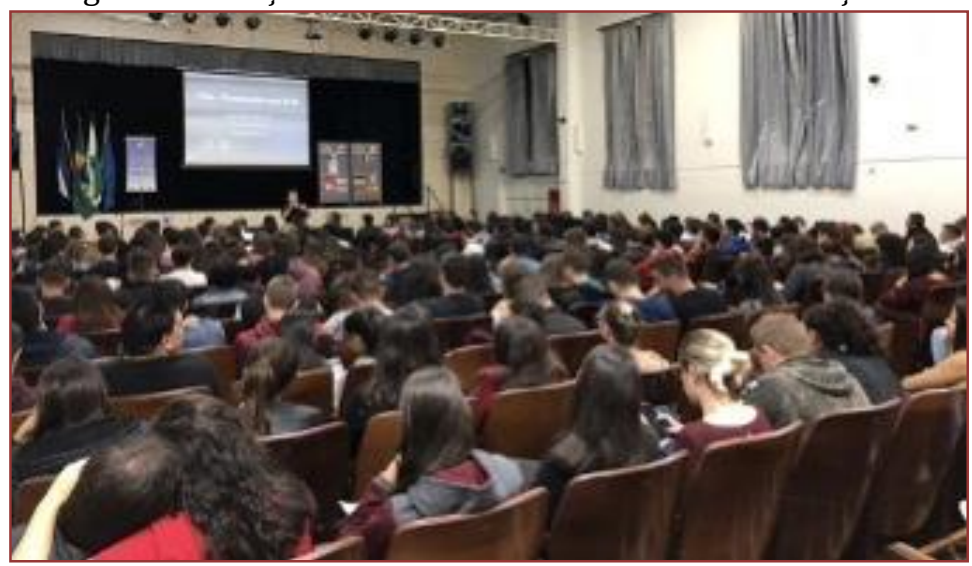

Legenda: Palestra de lançamento do II Fórum de Internacionalização, 2019. 
Já no período de 10 a 12 de junho de 2019, foi realizado o 2ํㅜ Fórum de Internacionalização do Curso de Administração da UEPG. Adotou-se, para esse evento, um novo formato, buscando propiciar, especialmente aos acadêmicos, diferentes experiências de internacionalização, a fim de mostrar que não é necessário viajar ao exterior para se experimentar uma vivência internacional. A realização desse Fórum resultou na participação no 37ํㅗㄹ, realizado em Florianópolis/SC.

Ao longo de 2019, partindo da experiência intercultural vivenciada no 2 o Fórum, foram realizadas palestras, em língua inglesa, com executivos brasileiros e estrangeiros. 0 projeto Departures trouxe para os acadêmicos o diretor para a América Latina de uma multinacional chinesa (AEOLUS); o diretor de desenvolvimento de negócios no Brasil, de uma multinacional holandesa (DAF Trucks); o diretor geral de uma empresa brasileira com negócios internacionais (AGROICONE) e a gerente global de treinamento e desenvolvimento de uma multinacional sueca (ELECTROLUX).

Ainda em 2019, o projeto Departures coordenou uma mesa-redonda no ADM 2019, denominada "MakingInternationalization Happen", no dia 04 de outubro, quando foram discutidas as perspectivas e os programas dentro da UEPG e relatadas as experiências internacionais de uma escola de ensino médio local (Colégio Sepam) e a vivência com o processo de "internationalization at home" do departamento de administração da UEPG.

Finalmente, em 2020, foi realizada a "Live: desmistificando a internacionalização acadêmica" (Figura 03), no dia 06 de julho, com uma psicóloga especialista em internacionalização acadêmica, sobre as principais barreiras mentais desenvolvidas por estudantes e que bloqueiam ou dificultam o início de um processo de internacionalização.

Além disso, foi realizada a participação no ADM2020 - Congresso Internacional de Administração, quando a coordenação do projeto conduziu uma "super-live" com profissionais da área de internacionalização acadêmica, professores e alunos que vivenciaram experiências de estudo e trabalho no exterior.

Figura 3 - Material de divulgação da Live Desmistificando a Internacionalização Acadêmica

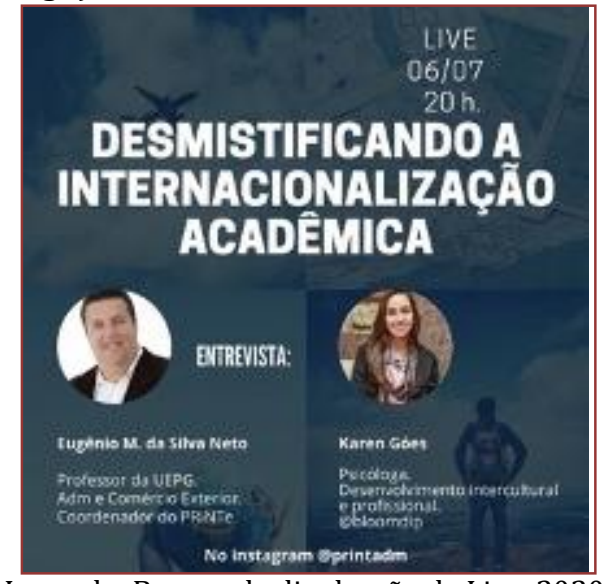

Legenda: Banner de divulgação da Live, 2020.

\section{CONSIDERAÇÕES FINAIS}

De acordo com Knight e De Wit (1995), a internacionalização consiste em atividades que buscam fornecer uma experiência internacional em um ambiente que integrauma perspectiva global (MARANHÃO et al., 2017) e, como Knight (2004, p.11) explica posteriormente, a internacionalização do ensino superior integra as dimensões internacional, intercultural e global.

Maranhão et al. (2017, p. 29), identificaram que estudantes universitários não realizam mobilidade internacional por dois principais motivos: falta de recursos financeiros (38\%) e falta de oportunidade (29\%). Com base nisso, é possível afirmar que as ações voltadas à Internacionalização em casa (IAH Internationalizations at Home) contribuem com a aproximação a uma realidade internacional, tanto pela redução de custo quanto pela oferta de oportunidades. Entende-se, portanto, que o presente projeto contribui, por meio de suas diversas ações, para o alcance dos objetivos propostos e para a internacionalização do curso de administração. Percebe-se que os alunos estão interessados, os professores estão comprometidos e a comunidade está respondendo positivamente para esse movimento que parte de dentro da universidade. 
A internacionalização é uma realidade e a mobilidade, segundo Urry (2005), tanto física quanto virtual, é uma característica do homem pós-moderno. Assim, para que a internacionalização do curso seja efetiva, torna-se imperativo pensar na curricularização da internacionalização e na adequação do projeto pedagógico do curso de administração com vistas a contemplar tal aspecto e na continuidade das ações que o projeto Departures vem desenvolvendo.

O projeto conta com o apoio da PROEX/UEPG na manutenção da discente bolsista do projeto.

\section{REFERÊNCIAS}

[1] MARANHÃO, C. M. S., COTADUTRA, I. I., MARANHÃO, R. K. A. Internacionalização do ensino superior: um estudo sobre barreiras e possibilidades. Administração: ensino e pesquisa, RJ, v. 18, n. 1, p. 9-38, 2017.

[2] URRY, J. Les systèmes de la mobilité. Cahiers internationaux de sociologie, n.118, p. 23-35, 2005.

[3] KNIGHT, J.; DE WIT, H. Strategies for internationalisation of higher education: Historicaland conceptual perspectives. Strategies for internationalisation of higher education: A comparative study of Australia, Canada, Europe and the United States of America, European Association for International Education, v. 5, p. 32, 1995.

[4] . Internationalization remodeled: Definition, approaches, and rationales. Journal of Studies in International Education, v. 8, n. 1, p. 5-31, 2004. 


\section{Capitulo 13}

Levantamento de pesquisas sobre internacionalização no campo de currículo em eventos luso-brasileiros

\section{Ana Lisa Nishio}

\section{Jussara Cassiano Nascimento}

Resumo: Nesse texto, apresentamos o trabalho de pesquisa desenvolvido na disciplina Prática de Pesquisa II, coordenada pelos professores doutores Antônio Flávio Barbosa Moreira e Dayse Hora, na Universidade Católica de Petrópolis, localizada no Rio de Janeiro, Brasil., foi-nos Primeiramente, proposto levantar dados no conjunto dos trabalhos apresentados nos Colóquios Luso-Brasileiros realizados no período de 2000 a 2008. Tal investigação estava vinculada ao projeto do Professor Doutor Antonio Flávio Barbosa Moreira apresentado ao CNPq, cujo tema é "A internacionalização do Campo do Currículo: condições, desafios e possibilidades de um novo paradigma." A base teórica e metodológica, se espelha nos trabalhos de Moreira (1997, 1999, 2012), Pacheco (2002), Pinar (2006) e Silva (1999). Das categorias selecionadas pelos professores, elegemos para os nossos estudos: o cosmopolitismo e hibridização, porque acreditamos que as práticas cotidianas fornecem indícios e um possível entendimento sobre os currículos que são praticados.

Palavras-chave: Currículo; Internacionalização; Prática de pesquisa. 


\section{INTRODUÇÃO}

O objetivo desse texto foi apresentar o trabalho desenvolvido no ano 2013 na proposta de prática de pesquisa I, coordenada pelos professores Antônio Flávio Barbosa Moreira e Dayse Martins Hora, na Universidade Católica de Petrópolis, localizada no Estado do Rio de Janeiro.

O grupo era formado por estudantes de Doutorado, Mestrado e Graduação, além dos dois professores. Nossos encontros aconteceram às quartas-feiras e tivemos como proposta de trabalho: realizar pesquisa no conjunto dos trabalhos apresentados nos Colóquios Luso-Brasileiros realizados no período de 2000 a 2006.

A investigação desenvolvida foi vinculada ao projeto de pesquisa do Professor Doutor Antônio Flávio Barbosa Moreira apresentado ao CNPq, cujo tema era "A internacionalização do Campo do Currículo: condições, desafios e possibilidades de um novo paradigma", onde o objetivo geral proposto é

compreender o atual processo de internacionalização do campo do currículo, tal como se está expressando em eventos e textos associados à International Association for the Advancement of Curriculum Studies (IAACS), à American Association for the Advancement of Curriculum Studies (AAACS) e aos Colóquios Luso-Brasileiros sobre Questões Curriculares, bem como nas perspectivas de seus principais promotores ( MOREIRA, 2012, p.217).

Moreira (2012) ainda nos esclareceu que o campo do currículo tem sido alvo de sua atenção desde a elaboração de sua tese de Doutorado, onde buscou compreender a emergência do campo do currículo no Brasil, sob a influência americana (p.216). Para ele, a internacionalização do campo do currículo não é um fenômeno recente, tendo em vista que seus reflexos vem sendo observados desde a nova influência da sociologia do currículo e os Colóquios Luso-Brasileiros têm representado momentos em que pesquisadores brasileiros e portugueses se reúnem e trocam experiências de trabalho e de pesquisa.

O projeto apresentado pelo Professor Dr. Antônio Flávio ao CNPq envolveu uma série de etapas, tendo sido organizada de forma prévia e provisória, tendo início em 2010 até 2014.

Portanto, iniciamos este texto contextualizando os encontros de pesquisa na Universidade Católica de Petrópolis, logo depois apresentamos brevemente o movimento que vem sendo denominado de Internacionalização do campo do currículo; a seguir incluímos algumas considerações sobre as categorias cosmopolitismo e hibridização que estiveram presentes nas mesas redondas do Colóquio de 2008 e que privilegiamos para destacar neste texto. Por fim, vamos desenvolver algumas considerações sobre todo o trabalho apresentado.

Dentre as diversas categorias, selecionadas por nós, pesquisadores, escolhemos as categorias cosmopolitismo e hibridização, por acreditarmos que as práticas cotidianas que são desenvolvidas nas escolas, fornecem inúmeros indícios para a compreensão das redes complexas que nelas se formam, pois a partir do seu estudo, é possível um entendimento sobre os currículos que são praticados.

\section{METODOLOGIA - CONTEXTUALIZANDO NOSSOS ENCONTROS}

O Projeto de pesquisa organizado pelo Professor Dr. Antônio Flávio foi proposto ao CNPq para ter uma duração de 5 (cinco) anos, tendo início em 2010. Porém, demos continuidade ao projeto em março de 2013, na Universidade Católica de Petrópolis, onde 14 (quatorze) estudantes se reuniram uma vez por semana, durante todo semestre nas dependências da Universidade, para discutir questões voltadas para a pesquisa que estaríamos desenvolvendo.

Como pesquisadores, estávamos buscando um caminho na quantidade de dados, que coletamos do conjunto de trabalhos apresentados nas edições de 2002, 2004 e 2006 eleitas para o estudo. Por onde começar, o que fazer e como fazer? Nossa preocupação era a de como realizar uma pesquisa de grande porte. A pesquisa Survey foi sugerida, por se tratar de um método de coleta de informações diretamente de pessoas a respeito de suas ideias, sentimentos, saúde, planos, crenças e de fundo social, educacional e financeiro, e que estivesse vinculada aos Congressos Luso Brasileiros. Porém, concluímos que isso ocorreu indiretamente através da formulação de tabulações dos dados coletados.

Foram necessários alguns encontros de orientação com a professora Dayse Hora, para que pudéssemos traçar um caminho que direcionasse nossos estudos e pesquisas. Em primeiro lugar, foi acordado que iríamos trabalhar em duplas, com os textos desses Colóquios a partir de 2002, sabendo que este foi o ano 
do I Congresso Luso Brasileiro, realizado em Portugal. A partir de 2002, a cada dois anos ele passou a acontecer com edições alternadas em Portugal e no Brasil.

Mas o que fazer com esses textos? Pensamos em tabelar os diversos textos fazendo uso do aplicativo do Office, chamado Excel. Mas como categorizá-los? Depois de muitas discussões, iniciamos os trabalhos, nomeando os textos e ajustando-os em categorias que identificamos com recorrentes e que emergiam das análises dos resumos dos trabalhos apresentados no evento.

Essas categorias foram assim elencadas: Identidade, Conhecimento escolar, Tradução, Transferência e Transformação, Cosmopolitismo e Hibridismo, Gênero, Diferença, Etnia e Raça, Sexualidade, Internacionalização, Globalização e mundialização, Metodologia, Multiculturalismo, Avaliação, Formação inicial e continuada, Tecnologias de comunicação e informação e outros.

Para o preenchimento da tabela, selecionamos títulos e todos do grupo combinamos em completar usando fontes maiúsculas. Os títulos utilizados para a tabela foram construídos da seguinte forma: número do artigo no CD, nome do artigo, data da classificação, nome do aluno responsável, ano, país, cidade/estado, instituição de origem, autor e/ou outros autores, tipo de apresentação, temática, categoria, cenário 1 e cenário 2 (estes cenários estavam ligados a ser um texto voltado para ensino público ou privado).

Além de preenchermos a tabela em Excel, era necessário fazer um breve resumo sobre o texto, onde seria colocado o título do artigo, o ano do Colóquio, e o número do artigo, trazendo as principais ideias abordadas.

Semanalmente cada estudante-pesquisador deveria incluir na tabela os dados coletados nos livros impressos ou CDs dos Colóquios Luso Brasileiros de 2002, 2004 e 2006. Esses materiais nos foram cedidos pelo Prof. Antônio Flávio durante nossos encontros. Em geral, cada estudante escolhia os textos que desejava trabalhar. Porém durante nossos encontros um embate se estabeleceu: o professor sugeriu que deveríamos usar somente as mesas redondas em nossas análises iniciais, devido ao curto tempo que tínhamos: somente um semestre. Portanto, passamos a fazer nossas classificações utilizando as mesas redondas. Somente para o Colóquio de 2002 (o primeiro que tabelamos) foram utilizados os textos das comunicações livres além dos textos das mesas redondas.

Combinamos fazer uma espécie de ata, intitulada por nós de "diário de bordo" no qual seriam registrados os encontros de pesquisa, pois ele serviria para que tivéssemos um registro escrito de tudo o que foi acordado, em cada encontro, principalmente no caso de algum pesquisador não estar presente naquele dia.

Moreira (2012) destaca a relevância desta pesquisa, uma vez que aborda com profundidade as recentes mudanças pelas quais passa esse campo, e pela intenção de propiciar uma compreensão mais aguçada das trocas culturais que hoje se estimulam e se desenvolvem.

Terminamos o semestre com o trabalho que nos propomos a tabelar concluído, porém os professores Antônio Flavio e Dayse Hora, nos propuseram escrever um texto sobre a experiência de trabalhar em um grupo de pesquisa, catalogando dados para realização de uma pesquisa de grande porte. Entretanto, além dessa experiência, seria necessário escolher uma das categorias selecionadas por nós, trazendo questões do currículo abordadas por autores diversos.

Após preenchermos todos os campos da tabela, que foram catalogados de acordo com as nossas classificações, ou seja, a partir dos trabalhos apresentados nos Colóquios Luso-Brasileiros de 2002 a 2006, percebemos a existência efetiva dessa internacionalização do campo do currículo. E, de forma semelhante a Pinar (2003) e Moreira (2009), observamos que cresce e se desenvolve um campo cada vez mais sofisticado, derivado de uma sugestiva conversação com colegas de diferentes países. Portanto, é preciso discutir a configuração de um campo de estudos que se amplia em nível mundial.

\section{REFERENCIAL TEÓRICO - O PROCESSO DE INTERNACIONALIZAÇÃO NO CAMPO DO CURRÍCULO}

O campo do currículo vem passando nos dias de hoje, por um processo de internacionalização que está se desenvolvendo de forma acelerada, cujos sinais já se podem verificar há alguns anos. Encontros organizados entre pesquisadores de diversos países demonstram a força que essa mudança paradigmática vem tomando, desde a primeira década do século XX.

Foram criadas algumas associações e reuniões internacionais que representam fontes importantes nas discussões sobre a internacionalização deste campo. Espaços de discussões como o que aconteceu na China, na Finlândia em 2006, na África do Sul em 2009 e no Rio de Janeiro em 2012, mostram o quanto a internacionalização do currículo vem se mostrando em expansão. 
Os Colóquios Luso-Brasileiros também refletem o crescimento desse campo, pois se constituem como uma das iniciativas vinculadas a essa internacionalização do currículo. Os Colóquios vêm acontecendo desde 2002, e além de contarem com a participação de pesquisadores portugueses e brasileiros, registram a participação de pesquisadores dos Estados Unidos, da Argentina, Espanha, Finlândia, França e Canadá.

Percebe-se que acadêmicos de diversos países têm procurado reconfigurar e descentrar suas tradições de conhecimentos, de forma a obter um trabalho conjunto, com a finalidade de discutir variadas temáticas sobre o currículo. Porém, Moreira (2012) nos apresenta alguns questionamentos: quando especialistas de diversas origens se juntam, com histórias internacionais que envolvem colonização, dominação, alienação política e arrogância, como garantir um diálogo democrático? Como identificar relações de poder que se expressem nessa conversação?

A internacionalização tem sido compreendida como um encontro entre pesquisadores que se expande em nível mundial, onde eles se esforçam para entender e analisar o que acontece no âmbito do currículo, nas diversas nações. Seus fundadores desejam que esses encontros proporcionem apoio aos debates acadêmicos locais e internacionais sobre os processos educacionais que tem o currículo como seu contexto intelectual.

Segundo Silva (1999), toda teoria do currículo tem como pano de fundo a discussão do conhecimento a ser ensinado aos estudantes. Sendo assim, as discussões relativas aos conhecimentos escolares, são questões centrais para pesquisadores, mas também para os docentes que estão o tempo todo tendo que tomar decisões sobre o que deve ser priorizado para ensinar.

Em estudos desenvolvidos por Moreira em 1997, sobre o processo de transferência educacional, onde ele analisa a emergência do campo do currículo no Brasil sobre a influência norte-americana, verificou-se em uma primeira etapa que até o final dos anos 70, aconteceu no país uma adaptação instrumental do discurso curricular norte-americano com a intenção de aproveitá-lo para a nossa realidade. Moreira já afirmava que:

[...] não há transporte mecânico de conhecimento de um país a outro. Entre a transferência e a recepção, processos mediadores dentre os quais destacam-se o dinamismo e as especificidades do contexto receptor, bem como a atuação dos agentes envolvidos na transferência afetam o modo como determinada teoria ou prática estrangeira é recebida, difundida e aplicada (Moreira, 1997, p.5).

Porém, tendo em vista as significativas mudanças de ordem políticas, sociais e culturais que ocorreram tanto no panorama nacional quanto internacional, foi necessário realizar uma adaptação crítica desses materiais recebidos, tornando o campo do currículo mais autônomo.

No processo de internacionalização do currículo estão envolvidas relações de poder, uma vez que estamos o tempo todo selecionando, destacando, ocultando, propondo e impondo, ações a serem feitas, e é neste sentido que Silva (1999) argumenta que o currículo é também uma questão de poder.

Moreira (2009) em texto intitulado "Estudos de Currículo: avanços e desafios no processo de internacionalização" alerta para a necessidade de se descobrir e criticar algumas escolhas, que conscientes ou não, nem sempre norteiam por tolerância e solidariedade, sendo possível que outros interesses venham estimular a homogeneização cultural e necessidades locais.

Para isso, será necessário reconhecer a importância do diálogo entre os acadêmicos, estimulando-se a exploração de uma leitura incessante, que estimule outros questionamentos, outras interpretações de forma que elas possam apresentar uma nova solidariedade, pois segundo Moreira (1999), sempre haverá limites em relação ao que podemos entender do Outro e de nós mesmos.

Em análise dos editoriais do Transnational Curriculum Inquiry, Moreira (1999) constatou que a internacionalização implica num trabalho conjunto de estudiosos de diferentes países, com a intenção de configurar um campo que se caracteriza por uma perspectiva transnacional, mas não uniforme.

Moreira (1999) acrescenta ainda que os textos redigidos por Gough (2004) e Pinar (2005) que compõem o primeiro editorial do Transnational Curriculum Inquiry, podem ser considerados fundamentais para que se possa compreender a visão de internacionalização sustentada pela revista.

Após uma década, Moreira (2009), ressalta a importância dos Colóquios Luso-Brasileiros sobre questões curriculares enfatizando que constituem uma das iniciativas que podem ser associadas à internacionalização do campo. Segundo ele, além da presença de estudiosos de Portugal e do Brasil, os colóquios têm propiciado a participação de pesquisadores dos Estados Unidos, da Argentina, Espanha, 
Finlândia, França e do Canadá. Aproximam-se, assim, especialistas de distintos países, contribuindo para que se socializem questões e teorizações tanto de interesse geral quanto local.

O autor relata em seu artigo "Estudos de currículo: avanços e desafios no processo de internacionalização" os temas centrais dos colóquios já realizados, incluindo-se o que ora se desenvolve, expressando determinadas tendências nos rumos dos elos que têm aproximado investigadores brasileiros e portugueses. Considerando que as temáticas dos quatro colóquios foram, respectivamente, Currículo e Produção de identidades; Currículo: Pensar, Inventar, Diferir; Globalização e Educação: desafios para políticas e práticas; e Currículo, teorias, métodos, o autor chama a atenção para as introduções dos anais dos encontros e permite considerar que as atenções dos pesquisadores se têm voltado, expressivamente, para as relações entre currículo e conhecimento escolar e entre currículo e cultura, temas clássicos nos estudos de currículo, que parecem continuar a despertar o interesse dos participantes. Também acrescenta que nesse amplo panorama, algumas temáticas mais específicas se destacaram - identidade, diferença, desigualdade, inclusão, políticas curriculares -, abordadas tanto segundo realidades locais quanto com referência a contextos internacionais (Pacheco, 2002; Moreira, Pacheco, Garcia, 2004; Moreira, Pacheco, 2006).

Os focos observados nos colóquios confirmam os pontos de vista de Silva (1999), para quem toda teoria de currículo tem como pano de fundo a discussão do conhecimento a ser ensinado aos estudantes. Ao mesmo tempo, acrescenta Silva (1999a), a pergunta relativa ao que ensinar jamais se separa de outra: que se espera que os alunos venham a ser? Em síntese, as preocupações com o conhecimento escolar e com as identidades dos estudantes têm merecido a atenção de pesquisadores de distintos países. Cabe esperar que essas (e outras) temáticas venham a inspirar estudos que possam incrementar a internacionalização do campo e contribuir para sua maior sofisticação teórica, assim como para consolidar o compromisso dos pesquisadores com justiça social e equilíbrio ecológico (Pinar, 2006).

Gough (2004) argumenta que novos públicos transnacionais podem produzir narrativas mais defensáveis para o trabalho em currículo do que o nacionalismo; fazendo-se necessárias o uso de outras linguagens empregadas no discurso curricular. Pinar (2005), aposta num encontro entre a tradição chinesa e a canadense, onde aconteçam vantagens nessa relação dinâmica, chamada por ele de "conversação complicada", fazendo com que aconteçam avanços no campo do currículo.

\section{RESULTADOS E DISCUSSÃO}

Ao levantar questões de natureza política e social, alguns trabalhos nos Colóquios suscitam perguntas como: A aposta no currículo comum para todos é de fato uma via para a conquista da justiça social? O debate sobre a composição de currículos, na Educação Básica, é uma absoluta necessidade, porque "aí se está decidindo a base da formação cultural comum para todos os cidadãos, seja qual for sua origem social, independentemente de suas probabilidades de permanência no sistema educativo em níveis de educação não obrigatórios"? (BORDIEU 1998, GIMENO SACRISTÁN, 2000, PINAR, 2009)

Por outro lado, diante de uma sociedade globalizada, com o advento de recursos tecnológicos jamais vividos em outras gerações, que homogeneidade encontraremos? Concordando com Pinar, Moreira (2009, p.368) defende a "viabilidade de um processo de hibridização cultural, no qual elementos de distintas origens e posições hierárquicas se desterritorializem e se reterritorializem" Sobre isso ou excerto é importante de ser considerado em nossa análise.

Ao mesmo tempo que se difundem os benefícios decorrentes da ampla mobilização de conhecimentos científicos de todos os tipos, esboçam-se com mais intensidade os riscos decorrentes das traduções e interpretações pasteurizadas de uma mídia globalizada, nas quais as imagens da realidade e as visões de mundo transmitidas são as que beneficiam os grupos sociais poderosos. Assim, diferentes saberes, formas de vida e visões de mundo encontram-se, atritam-se, confrontam-se, subordinam-se, renovam-se. Se o processo pode causar homogeneização, invasão, destruição de manifestações culturais, pode, por outro lado, estimular uma apropriação crítica de ideias e teorias elaboradas pelo "outro". (MOREIRA, MACEDO, 2006, p.18-19)

Mostra assim sua defesa em relação à categoria hibridização. Da mesma forma, defende a categoria cosmopolitismo, argumentando (MOREIRA, MACEDO, 2006) em prol da compreensão do processo de trocas culturais, que expressa uma posição em relação à diversidade, uma predisposição de se envolver com o outro, "a uma busca de contrastes, ao invés de uniformidade". 
O cosmopolita seria um indivíduo livre para recolher de uma dada cultura somente o que lhe interessasse, ou, então, para aceitá-la de modo mais amplo. Acolhendo parcial ou totalmente a cultura estrangeira, o cosmopolita não se limitaria ao compromisso com esta; ao contrário, garantiria sempre sua habilidade de "encontrar a saída". 0 cosmopolita utilizaria sua mobilidade para incorporar, crítica e seletivamente, experiências e significados apreendidos em sua trajetória por inúmeros territórios culturais. Na sociedade global, o intelectual cosmopolita seria capaz de explorar as oportunidades e os efeitos decorrentes do incessante fluxo de ideias e teorias, bem como de empregá-las para evitar homogeneização e situações de opressão e de imperialismo. (MOREIRA, 2009, p.376)

Concordando com os autores, verifica-se que essa citação demonstra a necessidade do diálogo acadêmico, o qual deve acontecer dentro e fora das Universidades; é necessário aprofundar e socializar as pesquisas e os estudos que se dediquem nas escolhas dos conteúdos, a partir do contexto e no desdobramentos dos processos educativos, culminado no currículo. Os resultados desses diálogos tendem representar consideráveis conquistas na proposta de se aumentar a compreensão do processo curricular, como afirma Moreira (2009).

\section{CONSIDERAÇÕES FINAIS}

Concluímos, afirmando que é de grande valia para as análises sobre o currículo a compreensão da Internacionalização do seu Campo, assim como a fundamentação teórica nessa área através dos autores envolvidos e das categorizações necessárias para a melhor compreensão do estudo.

Nessa proposta, o trabalho de pesquisa em equipe provou uma fala do professor Moreira (2009, p.379) “[...] nessas conversas, deseja-se a confluência, mas não a homogeneização, de distintos modos de pensar, de imaginar e de improvisar. Nelas, autonomia, respeito e cosmopolitismo precisam ocupar lugares de destaque, para que não se desvalorizem ou se subjuguem discursos, vozes e interesses locais." Ou seja, um grupo diversificado em relação à história de vidas, de formação e proposta de pesquisa se auxiliou mutuamente alcançando até objetivos não previamente estabelecidos.

Diante da diversidade de histórias de vida, de comportamentos, das infinitas possibilidades de aprender, de transcender, de viver, verificamos a importância do debate constante que favorece o enriquecimento de novas propostas e que superem o pensamento "local" e desenvolva uma rede onde todos tenham as mesmas oportunidades de encontrar benefícios nesse debate.

\section{REFERÊNCIAS}

[1] BORDIEU, Pierre. Escritos de Educação. Petrópolis: Vozes, 1998.

[2] GIMENO SACRISTÁN J. O currículo: os conteúdos do ensino ou uma análise prática. In:

A. I. Compreender e transformar o ensino. 4. ed. Porto Alegre: ArtMed, 2000. Cap. 6, p. 119-148. ; PÉREZ GÓMEZ,

[3] GOUGH, N. Thinking globally in environmental education: implications for internationalizing curriculum inquiry. In: PINAR, W. P. (ed.) International handbook of curriculum research. Mahwah, London: Lawrence Erlbaum Associates, 2003. p.53-72.

[4] HANNERZ, U. Cosmopolitas e locais na cultura global. In: FEATHERSTONE, M. (org.) Cultura global: nacionalismo, globalização e modernidade. Petrópolis: Vozes, 1994. p.251-266.

[5] MOREIRA, A. F. B. Currículos e programas no Brasil. 3.ed. Campinas: Papirus, 1997.

[6] _ (org.). Currículo: Políticas e práticas. Campinas: Papirus, 1999.

[7] Estudos de Currículo: avanços e desafios no processo de internacionalização. Cadernos de Pesquisa, v.39, n.137, p.367-381, maio/ago. 2009.

[8] _. _. _ recente produção científica sobre currículo e multiculturalismo no Brasil (1995-2000): Avanços, desafios e tensões. Revista Brasileira de Educação, Campinas: Autores Associados/ANPED, 2001, no 18, p. 6581.

[9] .A internacionalização do campo do currículo. Revista Contemporânea de Educação N o 13 janeiro/julho de 2012 
[10] The Currículum field in Brazil: emergence and consolidation. In: PINAR, W. P. (ed.) International handbook of curriculum research. Mahwah, London: Lawrence Erlbaum Associates, 2003. p.171-184.

[11] _ MACEDO, E. F. Faz sentido ainda o conceito de transferência educacional? In: MOREIRA, A. F. B. (org.) Currículo: políticas e práticas. 9. ed. Campinas: Papirus, 2006. p.11-28.

[12] 2006.

[13] 2004.

[14] MOUFFE, C. O Regresso do político. Lisboa: Gradiva, 1996.

[15] PACHECO, J. A. Notas de abertura. In: MOREIRA, A. F. et al. (orgs.) Currículo e produção de identidades. Braga: Universidade do Minho, 2002. p.7-8.

[16] PINAR, W. F. Curriculum theory since 1950: crisis, reconceptualization, internationalization. Vancouver, 2006. mimeo

[17] ___ The Internationalization of curriculum studies: a status report. [Apres. no Encontro Anual da American Association for the Advancement of Curriculum Studies, New Orleans, 2002.] mimeo

[18] __. Introduction. In: PINAR, W. F. (ed.) International handbook of curriculum research. Mahwah: Lawrence Erlbaum Associates, 2003. p.1-31.

[19]___ The Synoptic text today and other essays: curriculum development after the reconceptualization. New York: Peter Lang, 2006a.

[20]___. What is curriculum theory? Mahwah: Laurence Erlbaum Associates, 2004.

[21] POLLOCK, S. et al. Cosmopolitanisms. In: BRECKENRIDGE, C. A. et al. (eds.) Cosmopolitanism. Durham, London: Duke University Press, 2002.

[22] RAGATT, P. One person's periphery. Compare, v. 13, n. 1, p.1-5, 1983.

[23] SANTOS, B. S. Os Processos da globalização. In: SANTOS, B. S. (org.) A Globalização e as ciências sociais. São Paulo: Cortez, 2002. p.25-104.

[24] SARLO, B. Escenas de la vida posmoderna: intelectuales, arte y videocultura en la Argentina. Buenos Aires: Ariel, 1999.

[25] SILVA, T. T. O Currículo como fetiche: a poética e a política do texto curricular. Belo Horizonte: Autêntica, 1999.

[26] ___. Documentos de identidade: uma introdução às teorias do currículo. Belo Horizonte: Autêntica, 1999 a. 


\section{Capítulo 14}

Dupla diplomação em Portugal: Percepção dos estudantes de Engenharia Civil da UTFPR dos Câmpus Curitiba e Pato Branco

\section{Renata Sá Brito Stramandinoli \\ Clarice Farian de Lemos \\ Gustavo Lacerda Dias}

Resumo: Neste artigo buscou-se apresentar as contribuições ocorridas com a implantação do Programa de Dupla Diplomação entre a Universidade Tecnológica Federal do Paraná e o Instituto Politécnico de Bragança, em Portugal, na formação dos alunos do curso de Engenharia Civil dos Câmpus Curitiba e Pato Branco. Para isso, foi elaborado um questionário com 38 questões entre abertas e fechadas, na qual os próprios alunos que terminaram ou em fase de conclusão das atividades da mobilidade pudessem mostrar a sua percepção sobre o programa. Dos alunos considerados para a pesquisa, 97\% desses responderam às questões e verificou-se os benefícios gerados, tanto no âmbito pessoal quanto profissional dos futuros profissionais de engenharia, bem como as oportunidades de melhoria para o Programa como um todo.

Palavras-chave: Engenharia Civil. Internacionalização. Dupla Diplomação. Educação Superior. 


\section{INTRODUÇÃO}

Graças ao fenômeno da Globalização, a internacionalização na educação superior adquiriu novas conotações a partir do final do século XX (MAUÉS e BASTOS, 2017). Porém, é preciso fazer a distinção entre os conceitos de globalização e internacionalização. A globalização se apresenta sob a forma multidimensional, abrangendo aspectos relacionados à economia, finanças, ciência, tecnologia, comunicações, educação, cultura e política (LAUS, 2012). Já no campo da educação superior, a internacionalização pode ser entendida como um conjunto de políticas e práticas desenvolvidas pelos sistemas acadêmicos, instituições e indivíduos para fazer frente ao ambiente global (LUCE et al, 2016).

Segundo Santos e Almeida Filho (apud MAUÉS e BASTOS, 2017), a internacionalização pode ser considerada a quarta missão da Universidade, depois das outras três: Ensino, Pesquisa e Extensão. Contudo, no Brasil, a internacionalização ganhou maiores proporções mediante o fomento do Estado, como se viu em programas como o Ciência sem Fronteiras (2011 - 2015), o Idiomas sem Fronteiras (2012-atual) e o Programa Institucional de Internacionalização da Capes (2018-atual) (LEAL, 2019).

No âmbito da UTFPR, a internacionalização faz parte das políticas de ensino da Instituição, através de diversas práticas, como: a Dupla Diplomação; a realização de estágios e/ou Trabalhos de Conclusão de Curso em outros países; apoios a convênios multilaterais de estudos, de pesquisa e de desenvolvimento; e intercâmbios pedagógico, científico, técnico, tecnológico e cultural, entre docentes, pesquisadores e discentes de diferentes IES (Instituições de Ensino Superior).

Dentro desse contexto, este trabalho visa apresentar as contribuições do convênio de Dupla Diplomação com o IPB (Instituto Politécnico de Bragança) na formação dos estudantes do curso de Engenharia Civil da UTFPR (Universidade Tecnológica Federal do Paraná), nos Câmpus Curitiba e Pato Branco, através de um estudo feito diretamente com os alunos participantes desse convênio.

\section{ACORDO DE DUPLA DIPLOMAÇÃO UTFPR E IPB}

Atualmente, a UTFPR oferece mobilidades acadêmicas internacionais com diferentes países e, no âmbito do curso de Engenharia Civil, tem-se firmado acordos de Dupla Diplomação com Institutos de Portugal, sendo um deles com o IPB (Instituto Politécnico de Bragança). Esse acordo foi assinado em 2017, em ambos os Câmpus (Curitiba e Pato Branco), na qual determina que os estudantes envolvidos devem permanecer matriculados na respectiva instituição de origem, e isentos do pagamento de taxas/anuidades (incluindo inscrição) na instituição anfitriã.

Os candidatos ao Programa de Dupla Diplomação têm que atender ao requisito de ter concluído, no mínimo, 7 períodos acadêmicos da sua graduação. Sendo que durante a mobilidade, os estudantes devem realizar 2 períodos letivos e, no seu retorno à UTFPR, concluir o período faltante, caso ainda não tiver realizado. Porquanto, o período de mobilidade internacional está estipulado para um ano e, caso seja necessário, há possibilidade de um adicional de 4 meses para finalização e defesa pública da dissertação/projeto/estágio no IPB, que corresponde ao relatório de estágio e TCC (Trabalho de Conclusão de Curso), na UTFPR. Ainda, para essa dissertação/projeto/estágio, o estudante deve ser orientado por professores doutores de ambas as instituições.

Embora a estrutura dos cursos não seja idêntica, a Dupla Diplomação foi consolidada por reconhecimento da graduação da UTFPR (5 anos) com a graduação (licenciatura) e o mestrado do IPB $(3+2=5$ anos). Portanto, após término do período de mobilidade internacional e conclusão da graduação na UTFPR, é atribuído o diploma de Mestre em Engenharia da Construção pelo IPB e é garantida a equivalência ao grau de Licenciado em Engenharia Civil, permitindo o exercício profissional em Portugal e, por conseguinte, na Comunidade Europeia.

\section{MATERIAIS E MÉTODOS}

Considerando o objetivo deste trabalho - que é investigar a percepção dos estudantes em relação à contribuição da Dupla Diplomação à sua formação - adotou-se o método de pesquisa quali-quantitativa, de caráter exploratório. Para tanto, usou-se, como sujeitos desta pesquisa, 31 alunos do curso de Engenharia Civil, dos Campus de Curitiba e Pato Branco, na qual já finalizaram o processo de mobilidade acadêmica ou que estão em fase de conclusão, com a defesa de dissertação marcada no IPB. Dentre estes, foram obtidas 30 respostas, ou seja, apenas um aluno não respondeu. 
O instrumento de coleta de dados foi um questionário, disponibilizado online através de ferramenta própria do Google, com perguntas abertas e fechadas. Ao todo foram 38 questões divididas em seis eixos: a) Dados de Identificação; b) Expectativa dos Estudantes; c) Gestão do Programa no Brasil e em Portugal; d) Disciplinas Cursadas e Rendimento Acadêmico; e) Sistema de Ensino; e f) Conhecimentos e Experiências Adquiridas.

As respostas foram armazenadas automaticamente em planilha Google Docs e permitiram realizar uma avaliação quantitativa, a partir do que os alunos assinalaram em suas respostas, com tratamento dos dados utilizando ferramentas estatísticas básicas disponíveis no programa Microsoft Excel; e uma avaliação qualitativa, com base no que os alunos comentam, a partir de suas percepções pessoais.

\section{RESULTADOS E DISCUSSÕES}

Por meio das respostas dos estudantes foi possível realizar a análise quantitativa e qualitativa dos aspectos referentes aos eixos mencionados no item 3 , conforme a percepção em relação à mobilidade acadêmica que vivenciaram. Dos alunos que responderam à pesquisa, 47\% (14 alunos) são do Campus Curitiba e $53 \%$ (16 alunos) são do Campus Pato Branco. Dentre esses estudantes, 8 alunos iniciaram a mobilidade em setembro de 2017, 8 e 10 alunos em fevereiro e em setembro de 2018, respectivamente e 4 alunos em fevereiro de 2019. Já, em relação à duração do período de mobilidade, têm-se no Campus Curitiba: 11 estudantes terminaram dentro do prazo de 12 a 16 meses, um terminou em menor tempo, 10 meses e 2 extrapolaram esse prazo (um em 18 e outro em 20 meses); e no Campus Pato Branco: 12 alunos finalizaram entre 12 e 16 meses, um extrapolou o prazo e 3 alunos estão em fase de conclusão, com a defesa de dissertação agendada.

\subsection{AVALIAÇÃO GERAL DA MOBILIDADE}

Nas respostas quantitativas, dos eixos "b" e "c", já definidos no item 3, foi utilizada escala Lickert, e as análises foram feitas em relação à média das respostas e o desvio padrão, com o propósito de perceber o grau de dispersão dos valores em relação à média. Foram também apresentados os valores mínimos e máximos de cada item, com a finalidade de identificar respostas discrepantes. Para as respostas dos demais eixos foram apresentados gráficos referentes às análises ou mencionados os resultados diretamente no texto.

\subsubsection{EXPECTATIVA DOS ESTUDANTES}

Sobre as expectativas dos estudantes ao se candidatarem ao Programa, foram considerados cinco itens para avaliação, em uma escala Lickert de 5 pontos (sendo 1 totalmente irrelevante e 5 totalmente relevante). Todos os itens tiveram uma resposta com média bastante elevada, como mostra a Tabela 1, sendo o item "Melhorar o currículo e a empregabilidade" o que obteve a maior média ficando em 4,97 (desvio padrão de $0,23)$ o que indica alta positividade. 0 item "Cursar disciplinas diferenciadas" foi o que teve a menor média $(4,06)$, mesmo assim, ainda alta. Isso mostra que todos estes itens foram importantes para os alunos se candidatarem ao Programa.

Tabela 1 - Expectativa dos Estudantes.

\begin{tabular}{|c|c|c|c|c|}
\hline Expectativa dos Estudantes & Média & $\begin{array}{l}\text { Desvio } \\
\text { padrão }\end{array}$ & Mínimo & Máximo \\
\hline Melhorar o currículo e empregabilidade & 4,93 & 0,25 & 4,00 & 5,00 \\
\hline $\begin{array}{l}\text { Ampliar experiências pessoais a partir de uma } \\
\text { nova inserção sociocultural }\end{array}$ & 4,80 & 0,48 & 3,00 & 5,00 \\
\hline $\begin{array}{l}\text { Adquirir experiência acadêmica internacional } \\
\text { para ampliar conhecimento em novos contextos } \\
\text { de aprendizagem: }\end{array}$ & 4,47 & 0,81 & 2,00 & 5,00 \\
\hline Poder trabalhar na União Europeia & 4,30 & 0,94 & 2,00 & 5,00 \\
\hline Cursar disciplinas diferenciadas & 4,10 & 1,08 & 2,00 & 5,00 \\
\hline
\end{tabular}


As etapas do Programa de Dupla Diplomação iniciam-se com o lançamento do Edital de Seleção. Nesse edital estão as informações do número de vagas, início do programa, requisitos mínimos, documentação necessária, dos prazos para inscrição e publicação dos resultados, dos critérios de seleção e classificação, entre outros. Além do aviso de que toda as despesas decorrentes da mobilidade internacional são de responsabilidade do estudante. Depois de selecionados, os candidatos encaminham os documentos, tais como: Plano de Estudos, cópia do passaporte, Histórico Escolar e Currículo, para a DIRINTER - Diretoria de Relações Internacionais, que envia para o IPB. No prazo máximo de um mês, a Carta de Aceite é disponibilizada e, juntamente com uma declaração da universidade, emitida pelo DERINT - Departamento de Relações Internacionais, o estudante pode iniciar o procedimento de obtenção do visto de estudo no Consulado Português, concomitante ao planejamento de sua viagem e estadia.

Todo o processo de encaminhamento dos selecionados para a instituição parceira portuguesa é acompanhado pela figura do PRAInt - Professor Responsável pelas Atividades de Internacionalização, com o apoio da Coordenação de Curso. Ao chegar ao IPB, os estudantes são recepcionados pelo Gabinete de Relações Internacionais e Diretor de Curso.

Portanto, neste eixo do questionário, os alunos foram indagados em 6 itens, sobre o grau de satisfação em relação à Gestão do Programa, também em escala Lickert de 5 pontos, sendo 1 muito insatisfeito e 5 muito satisfeito. Os resultados podem ser observados na Tabela 2.

Tabela 2 - Gestão do Programa.

\begin{tabular}{|l|c|c|c|c|}
\hline \multicolumn{1}{|c|}{ Gestão do Programa no Brasil e em Portugal } & Média & $\begin{array}{c}\text { Desvio } \\
\text { Padrão }\end{array}$ & Mínimo & Máximo \\
\hline $\begin{array}{l}\text { Apoio recebido pelo Coordenador do Curso e } \\
\text { PRAInt durante a mobilidade }\end{array}$ & 4,77 & 0,56 & 3,00 & 5,00 \\
\hline $\begin{array}{l}\text { Apoio recebido, durante a mobilidade, pela } \\
\text { Instituição em Portugal }\end{array}$ & 4,50 & 0,76 & 2,00 & 5,00 \\
\hline Grau de clareza do Edital & 4,20 & 0,87 & 2,00 & 5,00 \\
\hline $\begin{array}{l}\text { Apoio recebido pelo DERINT/DIRINTER durante a } \\
\text { mobilidade }\end{array}$ & 4,10 & 0,98 & 2,00 & 5,00 \\
\hline Pontuação do Edital & 4,07 & 1,00 & 2,00 & 5,00 \\
\hline $\begin{array}{l}\text { Apoio recebido, durante a mobilidade, pelo } \\
\text { Diretor de Curso em Portugal }\end{array}$ & 3,97 & 1,08 & 1,00 & 5,00 \\
\hline
\end{tabular}

Ainda que os valores médios sejam elevados nas respostas dos estudantes, há registro de notas baixas atribuídas a todos os itens, exceto o apoio recebido pelo coordenador de curso e PRAInt. Isso denota a necessidade de aprimoramento dos mecanismos burocráticos e de procedimentos internos das duas instituições para aprimorar o programa.

\subsubsection{DISCIPLINAS CURSADAS E RENDIMENTO ACADÊMICO}

Os alunos da UTFPR devem frequentar e obter aprovação de, no mínimo, 3 UCs (Unidades Curriculares) e, no máximo, 5 UCs do curso de mestrado no IPB, havendo necessidade de que sejam previamente acordadas no Plano de Estudos, previsto para o período de 12 meses. Logo, os alunos foram questionados sobre as disciplinas que cursaram na mobilidade e o rendimento que tiveram. Foram 8 itens, sendo 5 quantitativos e 3 qualitativos (destes 1 não obrigatório).

A primeira pergunta foi sobre quantas disciplinas cada aluno cursou durante a mobilidade. Os resultados são apresentados na Figura 1. Percebe-se que mais de dois terços dos alunos cursaram mais do que o número mínimo de 3 disciplinas previsto no acordo. Isto se deve a 2 motivos: interesse em assuntos específicos ofertados no IPB ou interesse em convalidar unidades curriculares na UTFPR após o retorno do intercâmbio. 


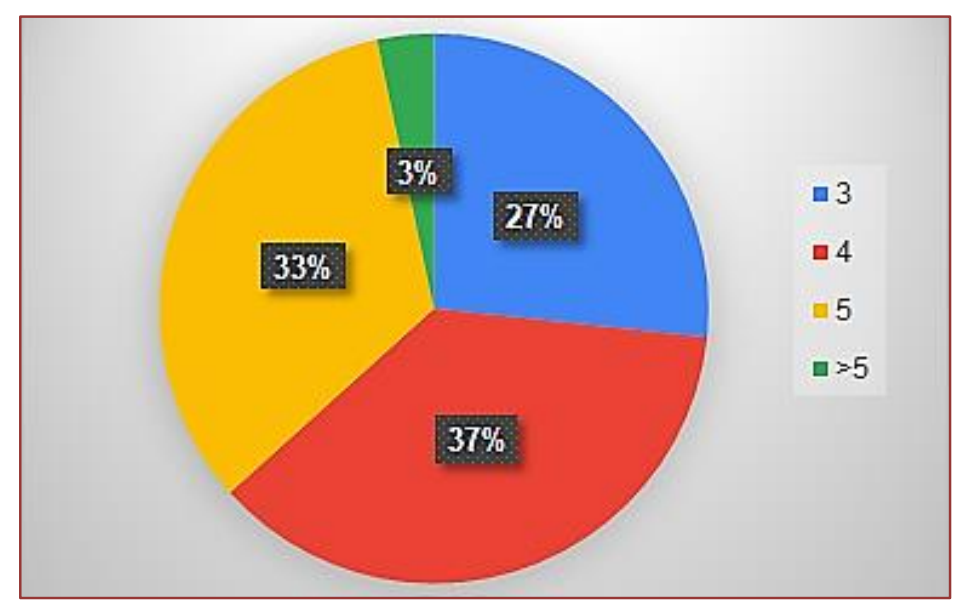

A segunda e terceira perguntas foram qualitativas e os resultados estão apresentados no item 4.2. Já a quarta pergunta trata da porcentagem das disciplinas cursadas no IPB que diferenciam das já cursadas na UTFPR (Figura 2). 0 gráfico mostra que para a maioria dos estudantes as matérias cursadas em Portugal eram diferentes das que já tinham cursado na UTFPR.

Figura 2 - Gráfico da Disciplinas diferenciadas.

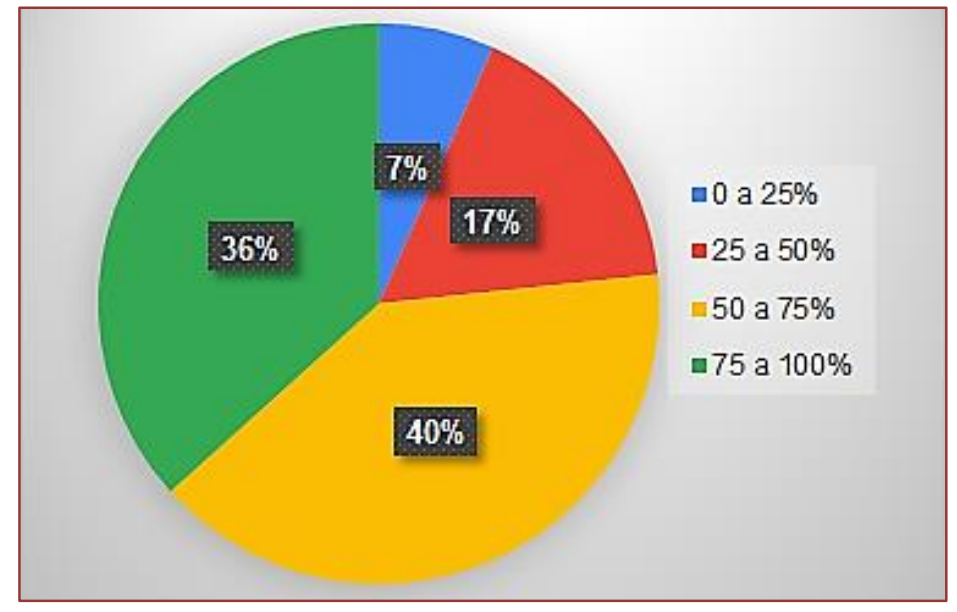

A quinta pergunta foi sobre o rendimento acadêmico em relação às disciplinas. Do total, $75 \%$ dos estudantes obtiveram um excelente rendimento nas disciplinas, rendimento entre 75 e 100\%; e 25\% tiveram um rendimento bom, entre 50 e $75 \%$.

As duas perguntas finais deste item, foram em relação à dissertação, na qual $100 \%$ dos alunos obtiveram um rendimento entre 75 e 100\%. Isso fortalece o programa e denota um grau elevado de comprometimento dos alunos da UTFPR na mobilidade. Embora os resultados tenham sido expressivos, com base na escala Lickert, apenas um aluno considerou a dissertação de nível fácil, 7 alunos consideraram de nível médio, 15 alunos de nível difícil e 7 alunos consideraram de nível muito difícil. 


\subsubsection{CONHECIMENTOS E EXPERIÊNCIAS ADQUIRIDAS}

Neste eixo os alunos foram questionados em relação a importância da mobilidade e das experiências que tiveram. Sendo as duas primeiras perguntas em relação a importância da mobilidade internacional à sua formação pessoal e profissional, respectivamente. Para ambas as perguntas foram utilizadas a escala Lickert de 5 pontos, sendo 1 sem importância e 5 muito importante. As respostas podem ser observadas na Figura 3. É possível observar que a formação pessoal foi mais importante que a profissional.

Figura 3 - Gráfico da Importância da Mobilidade Internacional na Formação Pessoal e Profissional

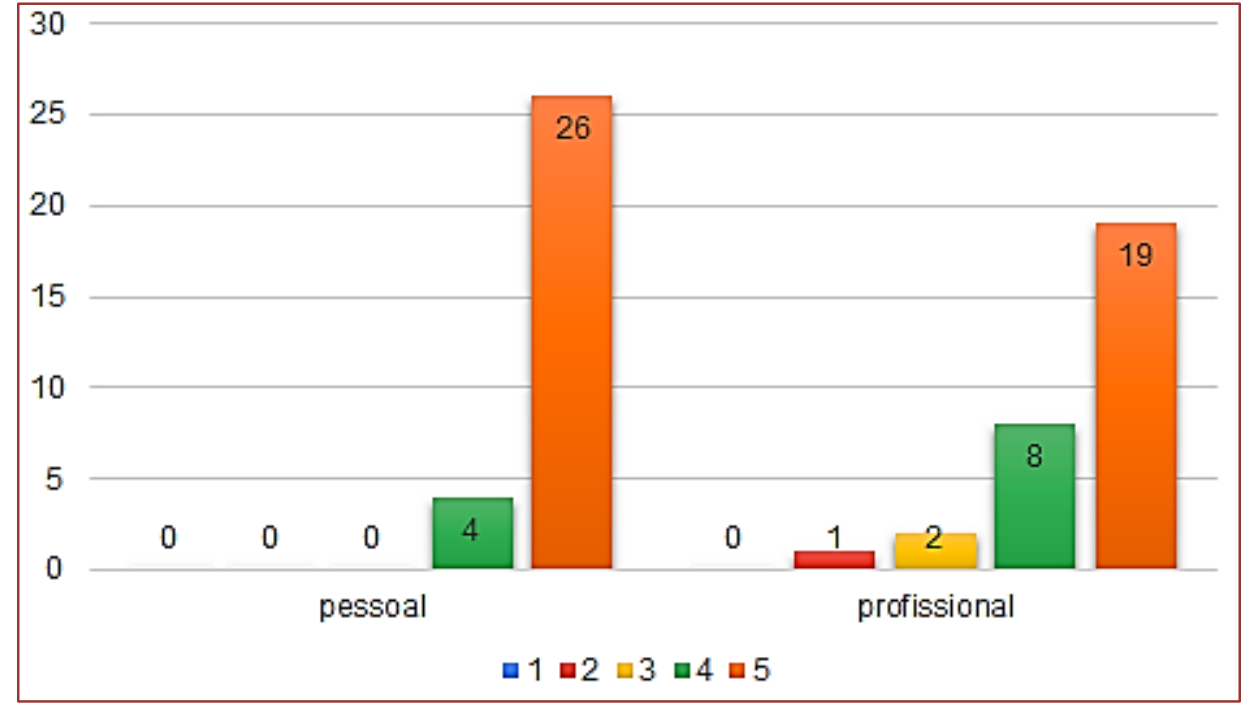

A quarta pergunta indagou se o estudante recomendaria aos demais alunos do curso a participarem do Programa, sendo que $80 \%$ dos alunos respondeu que recomendaria, e $20 \%$ respondeu que recomendaria, mas com ressalvas. Isto mostra o quanto os alunos aprovam o Programa.

\subsection{PERCEPÇÃO DOS ESTUDANTES SOBRE O PROGRAMA DE DUPLA DIPLOMAÇÃO}

Além das questões quantitativas, foram deixados campos abertos em determinados pontos do questionário, na qual os estudantes podiam se expressar livremente acerca dos pontos abordados nesta pesquisa. Permitindo assim, que as respostas qualitativas fornecessem uma riqueza de informações e traduzissem as percepções pessoais dos estudantes sobre a experiência vivida. A seguir são analisadas questões relativas a duas dimensões abrangidas pelo questionário.

\subsubsection{SISTEMA DE ENSINO NO INSTITUTO POLITÉCNICO DE BRAGANÇA}

Em linhas gerais, é possível perceber que a maioria dos alunos não veem diferenças significativas em termos de conteúdos de aulas e métodos de ensino entre a UTFPR e o IPB. Entretanto, há diferenças em determinados pontos que podem ser consideradas relevantes, tais como a maior autonomia requerida dos alunos, bem como a percepção de que há disciplinas que são mais voltadas para a prática do que a teoria, muitas vezes expressas em atividades de desenvolvimento de projetos a serem entregues ao final do semestre letivo. Eis alguns relatos interessantes:

[...] As metodologias são bem semelhantes, com aulas presenciais, trabalhos e avaliações.

[...] A maior diferença para mim era na quantidade de alunos em sala. Fazendo as disciplinas do mestrado a quantidade de alunos era de, em média, 10-12 alunos por aula. A maioria brasileiros. 
[...] O curso no Brasil é muito mais teórico, enquanto que na Europa os cursos são ligeiramente mais voltamos para a prática.

[...] As disciplinas têm, cada uma, um grande projeto a ser desenvolvido ao longo de todo o semestre. Os conteúdos apresentados ao longo das aulas vão se encaixando ao projeto como um quebra-cabeça, tornando a compreensão e aplicação destes conhecimentos algo mais simples e fácil de se realizar.

[...] Em muitos casos, as avaliações são feitas em formato de um projeto final, o que eu julgo muito útil. Os alunos tem a oportunidade de aprender um software e desenvolver um projeto similar aos que encontrariam na vida profissional.

[...] Em Transportes, o trabalhou resultou em um projeto de 87 páginas. Algo extremamente prático em que deu pra aplicar bastante a teoria, apesar de também ter sido aplicada uma prova com o conteúdo inteiro do semestre. Acredito que foi uma forma excelente de aprendizado que é difícil ocorrer na UTFPR.

A percepção sobre a autonomia dos alunos pode ser observada pelas seguintes narrativas:

[...] Os professores em geral desenvolvem mais pesquisas acadêmicas, mas esperam que o aluno desenvolva o trabalho de forma independente.

\section{[...] Pouca assistência dos professores na parte de exercícios e trabalhos.}

[...] Não recebi o apoio esperado pelo meu orientador que teve lado positivo e negativo. Negativo, pois não estava acostumado com isso e foi muito difícil concluir a tese. Positivo, por ter sido muito difícil e ter que ser feito muito por conta própria foi um ponto em que eu me desenvolvi muito em ser uma pessoa mais independente e responsável pelos meus próprios resultados. Avaliando de maneira geral, foi muito positivo para o meu amadurecimento.

[...] Acredito que o grau de dificuldade da dissertação seja justificado não pela dificuldade do tema, mas sim pela falta de orientação do orientador de Portugal, visto que era um tema novo e eu não possuía domínio.

\subsubsection{CONHECIMENTO ADQUIRIDO E BENEFÍCIOS DE TER PARTICIPADO DO PROGRAMA}

Analisando as respostas quanto às expectativas que os alunos tinham quando se inscreveram para o programa, e suas opiniões sobre a validade da experiência que tiveram, em linha geral há aqueles que ressaltam a abertura de possibilidades no campo profissional, enquanto outros enfatizam os ganhos no âmbito de crescimento pessoal. Entretanto, para uma parcela dos alunos, fica nítido que o principal objetivo pretendido e alcançado foi o de abrir portas de emprego na Comunidade Europeia, por conta da obtenção da titulação em Portugal. Isto fica expresso quando afirmam que: 
[...] Poder trabalhar na União Europeia foi disparadamente o maior motivo pelo qual me inscrevi.

[...] A experiência foi super válida. Já estou no meu segundo emprego como engenheira em Portugal. Também já recebi algumas propostas para trabalhar na Alemanha e na Inglaterra.

[...] Estou empregado na Irlanda pois sou Engenheiro também na Europa. Meu salário é 4 vezes maior que o salário médio dos meus ex-colegas de universidade.

Há também um número significativo de alunos que considera que o principal ganho com o intercâmbio foi no lado pessoal, ao terem a oportunidade de conhecer novas culturas e, para alguns, a possibilidade de vivenciar sua independência pessoal ao sair pela primeira vez da casa de seus pais. Isto fica evidenciado em relatos como:

[...] o benefício foi ter tido a chance, através de minha universidade no Brasil e do IPB, de conseguir andar sozinho, e acabar por me tornar independente de meus pais, como eles fizeram. Foi uma grande oportunidade de se mudar de vida e de aflorar perspectivas positivas sobre o futuro.

[...] A bagagem pessoal com certeza foi a mais impactada. Expandi meus horizontes, pensamentos e desenvolvi principalmente o autoconhecimento.

[...] Pessoalmente, a experiência internacional foi, juntamente com a minha ida para Pato Branco em 2013, as melhores experiências de vida que tive. Pude conhecer culturas e lugares novos, e valorizar também meu próprio país. Acredito que minha visão e objetivos para o futuro são muito influenciados pelo intercâmbio que realizei para Portugal.

Contudo, tem ainda aqueles que valorizam os conhecimentos técnicos adquiridos, ao relatarem pontos importantes, tais como:

[...] Serviu como ignição para meu desenvolvimento acadêmico com mais de 7 publicações, sendo algumas em jornais reconhecidos e aclamados pela comunidade científica da área.

[...] A experiência foi válida pelo fato de ter cursado disciplinas que não tive contato na UTFPR, voltadas à sustentabilidade na construção.

[...] Com certeza, acredito que esta experiência melhorou meu currículo, além do crescimento pessoal.

[...] Apesar de eu não ter como objetivo trabalhar fora do Brasil, a experiência internacional é muito valiosa perante as empresas e perante $o$ mercado como um todo. Profissionalmente, também tenho conhecimentos que não são tratados de forma geral no Brasil, como, por exemplo, o estudo térmico de edificações. 
Apesar do convênio de Dupla Diplomação entre a UTFPR e o IPB ser recente, o resultado tem sido expressivo para os alunos dos Câmpus Curitiba e Pato Branco, como pode ser observado na análise das respostas dos estudantes. É notável a satisfação dos estudantes pela oportunidade de terem uma experiência em outro país e os diversos relatos de crescimento pessoal e profissional.

Após a conclusão da Dupla Diplomação, aproximadamente 30\% dos alunos obtiveram oportunidades de trabalho ou de continuar os estudos em Portugal ou em outros países da Comunidade Europeia. Se por um lado isso pode significar uma perda para o Brasil pela evasão de jovens capacitados, no âmbito profissional o programa abre-lhes maiores perspectivas de empregabilidade.

0 relato de estudantes acerca dos benefícios pessoais em termos de crescimento pessoal é igualmente relevante, pois um dos propósitos do programa é contribuir na formação de cidadãos cada vez mais conscientes e tolerantes com as diferenças.

Finalmente, as respostas e relatos dos estudantes a respeito da gestão do programa no Brasil e em Portugal trazem contribuições para que diferentes aspectos do processo possam ser aprimorados. Há menção a questões burocráticas, como melhorias no edital de seleção, obtenção de vistos de estudante, enfim, a necessidade de centralização e padronização de encaminhamentos durante o intercâmbio. Além disso, houve relatos de estudantes que sentiram eventualmente necessidade de um melhor acolhimento dos portugueses e também da própria UTFPR em determinadas situações. Tudo isso fornece subsídios importantes para que as pessoas envolvidas na gestão do programa conheçam seus pontos fortes e fracos e possam torna-lo cada vez mais benéfico para nossos estudantes.

\section{REFERÊNCIAS}

[1] LAUS, Sonia Pereira. A internacionalização da educação superior: um estudo de caso da Universidade Federal de Santa Catarina. 2012. 319 f. Tese (Doutorado em Administração)- Universidade Federal da Bahia, Salvador, 2012.

[2] LEAL, Fernanda. A consolidação da 'internacionalização da educação superior' no Brasil segundo os moldes do capitalismo universitário global. Disponível em: https://iberoamericasocial.com/a-consolidacao-dainternacionalizacao-da-educacao-superior-no-brasil-segundo-os-moldes-do-capitalismo-universitario-global/. Acesso em: 27 mar. 2020.

[3] LUCE, Maria Beatriz; FAGUNDES, Caterine Vila; MEDIEL, Olga Gonzáles. Internacionalização da educação superior: a dimensão intercultural e o suporte institucional na avaliação da mobilidade acadêmica. Avaliação Campinas, Sorocaba, v.21, n.2, p. 317-339, 2016.

[4] MAUÉS, Olgaíses Cabral; BASTOS, Robson dos Santos. Políticas de internacionalização da Educação Superior: o contexto brasileiro. Educação, Porto Alegre, v.40, n.3, p. 333-342, 2017. 


\section{Capítulo 15}

Possibilidades do uso das Tecnologias da Informação e Comunicação em sala de aula

\section{Sunamita de Souza Belido}

\section{David de Brito}

Resumo: 0 objetivo geral deste artigo foi: demonstrar as possibilidades pedagógicas do uso das Tecnologias da Informação e Comunicação (TICs) em sala de aula. Entendendo a tecnologia como auxiliar no processo educacional, utilizada de acordo com os objetivos e competências a serem desenvolvidos. A tecnologia abre novas possibilidades em relação a abordagem do professor e a compreensão do aluno. Para melhor compreender o tema foi desenvolvido uma pesquisa bibliográfica, com método exploratório e análise qualitativa que consiste na leitura e análise de diversos pesquisadores com informações disponibilizadas em diversas fontes. Assim, foi possível constatar que unicamente a disponibilidade de recursos tecnológicos não é fator de melhoria do processo ensinoaprendizagem, a tecnologia é uma importante ferramenta para tornar a aula mais atraentes além de contribuir para inclusão social, pois está presente no cotidiano e o seu conhecimento é necessário para inserção do indivíduo na sociedade. Portanto, as tecnologias existem há muito tempo e, perpetuam até os dias atuais com programas que buscam levar a tecnologia a todas regiões, mas as escolas ainda não estão totalmente equiparadas para sua eficácia e eficiência, tão pouco, professores fazem verdadeiras obras na busca de uma educação de qualidade.

Palavras-chave: Tecnologias da Informação e Comunicação, Educação, Professor, Aprendizagem. 


\section{INTRODUÇÃO}

No decorrer do presente artigo serão discutidas as possibilidades do uso das tecnologias como instrumentos de avanços em sala de aula, assim, para melhor compreender os elementos aqui apresentados é necessário analisar que as mídias constituem os meios de comunicação com o uso das TICs, sendo assim, essa abordagem se alicerça no contexto da análise dos avanços tecnológicos no mundo escolar, considerando o processo ensino-aprendizagem.

Contempla-se no presente artigo que a escola é a segunda instituição que a pessoa faz parte (sendo a primeira a família) e, passa a ser uma das mais importantes na vida de cada indivíduo, todavia, é importante que existam resultados em todo o processo ensino-aprendizagem e, para isso, é importante discutir os instrumentos tecnológicos e a mídia como canal de comunicação entre professores e alunos.

Entende-se que para que a tecnologia ofereça bons resultados no processo de qualificação da comunicação na escola é essencial que professores e alunos possam se apropriar de forma ativa das tecnologias e das mídias, construindo um processo ensino- aprendizagem dinâmico e qualitativo a partir da construção de conhecimentos mediados pela tecnologia (DAMASCENO, 2009).

Assim, o desenvolvimento desse artigo é justificado pelo grande potencial existente no uso das TICs em sala de aula, como instrumentos de melhoria da aprendizagem, de forma a fomentar a comunicação construtiva e positiva entre professores -alunos, permitindo avanços na educação e nos resultados da aprendizagem.

Nesse sentido, o presente artigo foi elaborado tendo como objetivo geral: analisar como as Tecnologias da Informação e Comunicação (TICs) como podem aprimorar a comunicação professor/aluno e gerar avanços no processo ensino- aprendizagem.

Por tanto o uso das mídias nas escolas públicas brasileiras, em todo o país existem há muito tempo e, perpetuam até os dias atuais com programas que buscam levar a tecnologia a todas regiões, aumentar a inserção tecnológica nas escolas públicas e, reescrever a história da qualidade da educação em todos os níveis no Brasil, mas, para isso as mídias devem se apresentarem como possibilidades de avanços na educação.

\section{METODOLOGIA}

No momento em que buscamos o desenvolvimento de um estudo científico é importante o reconhecimento do melhor caminho metodológico a ser trilhado e, especificamente, no decorrer do desenvolvimento desse artigo a opção foi por uma pesquisa bibliográfica, com base em uma revisitação aos conceitos e estudos sobre o uso das mídias na educação, bem como, trouxe os avanços tecnológicos no traço histórico temporal, fazendo a relação do uso dessas tecnologias como elemento de qualificação de todo o processo ensinoaprendizagem. É um estudo aprofundado em dados secundários, que segundo Marconi e Lakatos (2013) é um primeiro passo para a estrutura de qualquer trabalho, pois, é a viabilização do conhecimento do pesquisador, a partir de estudos já trabalhados por outros pesquisadores, com informações disponibilizadas em diversas fontes.

Na concepção de Gil (2010), contempla um processo de estudo aprofundado, por parte do pesquisador, junto aos temas formadores da pesquisa, tanto o principal Tecnologia da Informação e Comunicação nas salas de aula, como os adjacentes (educação, professor e aprendizagem). Pode-se assim, dizer que o presente método teve o objetivo de discutir a influência da mídia no processo ensino-aprendizagem em sala de aula e, ainda na comunicação professor/aluno.

Com relação ao tipo de análise desenvolvida no artigo, este estudo trouxe a pesquisa qualitativa, que segundo o que avalia Gil (2010), constitui uma análise que eleva a forma interpretativa do pesquisador e contempla a estrutura ou reestrutura de conhecimentos, possibilitando ainda, a resposta ao objetivo geral traçado.

\section{AS TECNOLOGIIAS NA EDUCAÇÃO}

Quando se inicia a apresentação da tecnologia na educação no mundo contemporâneo é preciso apresentar o traço histórico do Brasil, assim, pode -se considerar que a década de 1940 foi o marco da iniciação do uso das tecnologias na educação no país, com a continuidade dessas ações até a década de 1970, quando tiveram origem as experiências de universidades federais com as TICs. Todavia, somente na Universidade de Brasília em 1981 e Universidade Federal da Bahia em 1982, iniciou um programa de informática na educação, se 
expandindo posteriormente para todas as universidades e demais instituições de ensino, surgindo assim, como instrumento nas escolas (CARDOSO et al., 2013).

A introdução das tecnologias na escola brasileira, de acordo com Leite (2010), surgiu no momento em que o país vivia num contexto econômico cujo objetivo era inserir o Brasil no mercado econômico mundial como produtor e consumidor de bens. Com isso, a proposta era levar para sala de aula novos equipamentos tecnológicos modernização pedagógica apoiou um modelo tecnicista que percebia a educação como um produzido pela sociedade industrial. Na educação, essa inserção da tecnologia para universo fechado e por isso não envolvia questões sociais. Nesse contexto surge a área de Tecnologia Educacional (TE) que, dentro da visão tecnicista, significava dar ênfase aos meios na educação sem questionar suas finalidades. A utilização da tecnologia na escola foi associada a uma visão limitada de educação, baseada em fundamentos teóricos e ideológicos externos (LEITE, 2010, p. 14). Contudo, a partir dos anos 80, a Tecnologia Educacional passou a ser entendida de forma mais critica o que permitiu a compreensão da utilização tecnológica na educação como uma forma de integrar as questões sociais ao cotidiano escolar, ampliando a visão crítica dos alunos. A inclusão da tecnologia no cotidiano da escola parece imprescindível, entretanto ela por si só não é capaz de ser determinante para qualidade de ensino. 0 docente precisa saber utilizá-la (se necessário) de acordo com o conteúdo que ele pretende ensinar. 0 domínio do professor deve se concentrar no campo crítico e pedagógico, pois assim ele evita ser vítima de imposição tecnológica na sala de aula, e pode ter a opção de integrar ou não a tecnologia em seu currículo, de acordo com os objetivos e competências a serem desenvolvidos, e ainda escolher o momento apropriado para fazê-lo. O professor não pode perder a dimensão pedagógica (LEITE, 2010, p. 16). A educação pode ser mediada pela tecnologia abrindo novas possibilidades em sala de aula para auxiliar na formação do indivíduo. Quando bem utilizadas as tecnologias promovem, de acordo com Kenski (2010), uma nova relação entre a abordagem do professor e a compreensão do aluno sobre o conteúdo veiculado.

“O desafio é o de inventar e descobrir usos criativos da tecnologia educacional que inspirem professores e alunos a gostar de aprender, para sempre” (KENSKI, 2010, p.67). É necessário investir na atualização dos professores já que a escola perdeu o papel de principal meio de transmissão de conhecimento. Os meios de comunicação, a televisão e a internet, por exemplo, estão ao alcance de todos e o professor pode ajudar o aluno a fazer uma leitura crítica, por exemplo, de um programa de televisão, promovendo assim um debate produtivo sobre assuntos em voga. A evolução dessas tecnologias vai desde a criação dos antigos sistemas postais até a invenção do telégrafo, do telefone, do rádio, da televisão, do computador, da telefonia celular, das redes de computador e de várias outras interfaces criadas para melhoria do processo de comunicação (PAIS, 2008, p. 93). Além disso, a incorporação das novas tecnologias em sala de aula promove constante mudança e o professor precisa assumir uma postura dinâmica diante da nova situação. Segundo Tajra (2001), a capacitação do professor para ser completa precisa envolver além de conhecimentos básicos de informática, novas formas de gerenciamento da sala de aula com os novos recursos tecnológicos em relação aos recursos físicos e ao aluno que agora passa a ter uma atitude ativa no processo. Além disso, a comunicação entre os professores é fundamental para que experiências sejam compartilhadas e para que as mudanças ocorram naturalmente.

\section{0 AVANÇO DA TECNOLOGIA NA SALA DE AULA}

O processo de desenvolvimento tecnológico alcançou a humanidade em todas as áreas e atividades, ainda mais no campo da comunicação, essa nova e dinâmica comunicação vem transformando a educação, não apenas por oferecer um volume de informações maior, como também, por originar novos canais de comunicação, que podem ser favoráveis para a relações professor/aluno, como também ser apenas novos instrumentos utilizados de forma inadequada (NASCIMENTO; HETKOWSKI, 2009).

Ao se falar em TICs e avanços tecnológicos a primeira observação é que são instrumentos contemporâneos, porém, o traço histórico da tecnologia disserta que a tecnologia é um processo longo, que tem sua origem com Tales de Mileto, quando em 700 a.C. (antes de Cristo), na Grécia iniciou as primeiras experiências com eletricidade, observando o resultado do atrito do âmbar junto a pele de carneiro. Importante citar que a palavra âmbar em Grego é élektron, fato este que originou o termo eletricidade (CURY; CAPOBIANCO, 2011).

Séculos depois da primeira experiência de Tales de Mileto, (século XVII), teve início as pesquisas, que objetivavam o uso da eletricidade, todavia, foi apenas no século XIX, no ano de 1873, que James Clerk Maxwell publicou um tratado sobre eletricidade e magnetismo, o que pode ser considerado o primeiro elemento de avanço da industrialização e uso das TICs, as quais têm papel essencial na mídia (CURY; CAPOBIANCO, 2011). 
De acordo com Tajra (2001), na década de 80 os países desenvolvidos transformaram a inclusão dos computadores nas escolas uma necessidade. Em 1983, 53\% das escolas dos EUA já utilizavam computadores com grande apoio de empresas privadas que atuavam nesta área. A França, por meio do Plano "Informática para Todos", e a Espanha, por meio do Projeto Atena, estimularam a formação de professores para o atendimento de vários alunos (TAJRA, 2001, p. 29). No Brasil, em 1995 foi criado pela Secretaria de Educação a Distância (SEED/MEC) um projeto denominado Proinfo (Programa Nacional de Informática na Educação) que visava a formação de Núcleos de Tecnologias Educacionais em todo o país. De acordo com o Ministério da Educação, o objetivo desses núcleos é capacitar professores para que estes possam multiplicar a política da Informática Educacional. 0 mais recente programa regulamentado foi o Programa “Um Computador por Aluno" (Prouca), trata-se de um programa em que estados, municípios e o Distrito Federal podem adquirir computadores portáteis para uso nas redes públicas de educação básica. 0 computador é uma máquina que possui diferentes utilidades: a interatividade, a criação de textos, planilhas, dentre outros recursos, tornando mais fácil o desenvolvimento de várias habilidades que contribuirão para formação do indivíduo. 0 professor capacitado pode encontrar várias formas de utilizar os diferentes programas disponíveis para planejar as atividades educacionais.

Aponta-se que o século XXI é um marco na história da revolução informacional e nos meios de comunicação, assim, em todos os ambientes, inclusive no escolar é preciso que os professores possam utilizar as tecnologias como instrumento para qualificar o processo ensino-aprendizagem, em todos os níveis escolares, tornando mais dinâmica a educação e gerando benefícios para o meio escolar, isto porque as salas de aula já não são as mesmas que há séculos, quando a tecnologia era menos participativa no cotidiano escolar (MAINART; SANTOS, 2012).

Ao se falar em avanços da tecnologia é importante apontar que é preciso observar a história da humanidade e, compreender que:

A primeira grande conquista tecnológica foi o livro que, há anos, vem sendo o carro-chefe tecnológico na educação e não constatamos que o livro é resultado de uma técnica. Por quê? Porque já incorporamos de tal forma que nem percebemos que é um instrumento tecnológico. [...] tecnologia só é tecnologia quando ela nasce depois de nós. 0 que existia antes de nascermos faz parte de nossa vida de forma tão natural que nem percebemos que é tecnologia (TAJRA, 2012, p. 37).

E o livro enquanto instrumento tecnológico é ainda hoje a principal ferramenta nas escolas e, tem papel relevante no processo ensino-aprendizagem, todavia, a cada dia vem sendo substituído, inclusive nas salas de aulas pelas ferramentas que geram informações e trazem a mídia como diversidade de comunicação.

No período da industrialização e do desenvolvimento tecnológico a escola foi um dos ambientes mais atingidos por esse processo de modernização, sendo primeiramente o quadro negro e o giz substituídos por um quadro branco e um pincel e, depois veio o retroprojetor, o qual logo foi substituído pelo projetor/datashow, nesse período houve o surgimento de um importante instrumento tecnológico nas salas de aula, o computador, que venho como um transformador na vida de professores e alunos, porém, essa mudança somente pode ser considerada um avanço se tais instrumentos são utilizados em prol do ensinoaprendizagem, tendo em vista que todo e qualquer recurso não constitui garantia de aprendizado é preciso que tais instrumentos sejam utilizados de forma produtiva, com a inserção da tecnologia em sala e não apenas dos equipamentos tecnológicos (FERNANDES; ZITZKE, 2012).

É claro que as primeiras ferramentas tecnológicas foram revolucionárias na sociedade e, também, na vida escolar, no entanto, é preciso observar que a cada ano tais instrumentos são tecnologicamente mais avançados e, teoricamente, mais relevantes para o aprendizado das crianças, mas, isso somente ocorre quando os professores sabem utilizar tais instrumentos, inclusive as mídias, tendo melhores canais de comunicação com os alunos. Assim, pode-se dizer que a evolução tecnológica está presente nas salas de aulas, mas, se não utilizada de forma adequada não trará a revolução na educação, tão necessária (FREITAS et al., 2014).

Os meios eletrônicos de comunicação são precursores da facilitação da coleta e transmissão de informações, bem como, são capazes de memorizar uma gama inimaginável até há uma década, isso porque possibilitam que as pessoas possam interagir com diversas formas de representação simbólica, tais como, textos, gráficos, imagens, notas musicais e imagens em movimento, com diferentes fontes como textos, livros, revistas e jornais, com vasto formatos de comunicação e informação como entrevistas, debates, documentários, filmes, novelas, músicas, noticiários, jogos, softwares, CD-ROM e, a Internet, sendo esses somente exemplos de mídias a serem utilizadas para a educação, buscando sua amplitude de saber e 
conhecer, para qualificar o processo ensino-aprendizagem em todos os níveis da escolaridade (MAINART; SANTOS, 2012).

O processo de evolução tecnológica que desaguou nas TICs trouxe uma gama importante de perspectivas em diferentes campos, especialmente, na educação, com novas perspectivas de comunicação e fontes de informações. Assim, a possibilidade de expandir todas as ciências e levar sempre mais longe o conhecimento se agigantou com os avanços tecnológicos, mas, tudo isso necessita ser trabalhado de forma adequada para que ocorra o aproveitamento desses instrumentos e, que a educação possa ser beneficiada com as mídias e demais TICs (CURY; CAPOBIANCO, 2011).

É interessante ainda comentar que no caso dos meios de comunicação, esses tiveram um processo de evolução relevante no limiar do século XX, com avanços na telefonia (especialmente a móvel), rádio, televisão e o computador, sendo esse último a mais importante fonte de informação e comunicação, que se utilizado de forma adequada pode transformar a escola e a aprendizagem (RABOY; SOLERVINCENS, 2006).

Considera-se que a partir da década de 1980, quando surgiram os primeiros computadores em rede e de portabilidade, ocorreu maior evolução das TICs, bem como influência dessas nas sociedades em todo o mundo e, evolução e revolução nas instituições escolares em todos os níveis, enfatizando a educação infantil, pois, esses instrumentos têm o potencial de encantar as crianças e motivar para a aprendizagem (CURY; CAPOBIANCO, 2011).

Assim, considera-se que as tecnologias e as diferentes mídias tornaram-se vitais para a globalização e a transferência de informações, bem como, quando corretamente utilizadas são essenciais para a qualificação da educação. Assim, o histórico evolutivo do uso desses instrumentos tecnológicos, especificamente, do computador tornou -se fundamental nas escolas, todavia, deve ser utilizado adequadamente como instrumento de aprendizagem (FREITAS et al., 2014).

Assim, segundo Fernandes e Zitzke (2012, p. 4): “O uso de variadas tecnologias deve ser constantemente reavaliado e readaptado para que cumpra com seu real papel: auxiliar alunos e professores na produção de conhecimento. [...]".

Recursos como a televisão, os jornais e revistas que se caracterizam como tecnologias de informação e comunicação podem ser utilizados em sala de aula para discussão de temas que estejam em voga. Os jornais e as revistas são um grande veículo de comunicação e de informação. 0 professor deve estar atento ao sensacionalismo das reportagens contidas nos jornais e revistas, visto que as redações jornalísticas, geralmente, utilizam expressões e argumentações que muitas vezes distorcem a realidade, visando atrair a atenção do leitor e o atendimento do retorno comercial (TAJRA, 2001, p. 136). 0 professor poderá auxiliar o aluno para que este enxergue a notícia além do que está escrito, fazendo uma leitura crítica do assunto.

Embora se observe o valor da tecnologia é preciso compreender que para uma educação de qualidade é importante que os recursos tecnológicos e os diferentes tipos de mídias sejam utilizados pelos professores com criatividade e incentivo para a aprendizagem, porém, não devem ser os únicos instrumentos de educação, especialmente para as crianças, outras técnicas de ensino não podem ser renegadas por seu potencial educativo, como, por exemplo, trabalhos em grupos, teatro, aulas de campo e conversação (FERNANDES; ZITZKE, 2012).

\section{RESULTADOS E DISCUSSÃO}

A partir da pesquisa realizada, fica claro que as tecnologias são necessárias em sala de aula, mas não indispensáveis. A ideia é auxiliar o professor na promoção de uma aula mais interessante que possibilite ao aluno novas descobertas e inclusive a inclusão social visto que a tecnologia está presente no cotidiano e para que um indivíduo possa fazer parte da sociedade efetivamente precisa conhecer, por exemplo, o computador e as suas utilidades. Contudo, deve- se investir na capacitação dos professores para que eles integrem a tecnologia com a sua proposta de ensino com segurança sobre o que estão fazendo. Desde os primórdios da humanidade, quando o homem deixou de ser nômade, fixou residência e passou a produzir seu próprio alimento, houve a necessidade de utilizar máquinas e demais equipamentos para facilitar sua atividade, todavia, todo esse processo foi construído durante séculos, chegando hoje ao ápice tecnológico com o computador e logicamente a Internet e todos os benefícios que esses instrumentos e mídias tecnológicas oferecem, além de outros meios de comunicação e informação, como a televisão e o rádio, bem como, os materiais que usam a tecnologia para serem impressos como jornais, revistas e livros, esses últimos de relevância inquestionável para a escola e a qualidade do processo ensino-aprendizagem. 
Com os levantamentos e análises teóricas realizadas fica claro que as TICs e as mídias são necessárias em sala de aula, são instrumentos de qualificação e aprimoramento da aprendizagem escolar, desde que professores/alunos tenham acesso a essas ferramentas e, saibam utilizar em sua amplitude, quebrando paradigmas no campo didático-pedagógico e, oferecendo aos alunos um ambiente favorável para o uso da tecnologia e o avanço do conhecimento. A ideia é auxiliar o professor na promoção de uma aula mais interessante que possibilite ao aluno novas descobertas e inclusive a inclusão social visto que a tecnologia está presente no cotidiano e para que um indivíduo possa fazer parte da sociedade efetivamente precisa conhecer, por exemplo, o computador e as suas utilidades. Contudo, deve-se investir na capacitação dos professores para que eles integrem a tecnologia com a sua proposta de ensino com segurança sobre o que estão fazendo.

\section{CONSIDERAÇÕES FINAIS}

Ao se falar sobre as tecnologias no aprimoramento da educação, concluiu -se que unicamente a disponibilidade de recursos tecnológicos não é fator de melhoria do processo ensino-aprendizagem, por isso é importante que professores/aluno tenham conhecimento sobre tais instrumentos, bem como, a tecnologia seja usada com foco na motivação e encantamento de alunos para que a aprendizagem seja criativa e crítica.

A escola deve estar voltada para promoção da educação, os professores devem compartilhar as experiências visando à melhora do processo de utilização das tecnologias em sala de aula. Até mesmo por se tratar do "novo", muitos professores podem ter várias dúvidas e criar muitas expectativas em torno da nova realidade. Mas é certo afirmar que o professor jamais será substituído pelos recursos tecnológicos, é a atitude dele (dentre outros fatores) que poderá aperfeiçoar o ensino e melhorar a educação. No Brasil, várias ações estão sendo realizadas para que o acesso às tecnologias utilizadas na sociedade moderna seja possível para todos, contudo ainda há muito a ser feito.

Por tanto concluiu-se que o uso das mídias nas escolas públicas brasileiras, em todo o país teve início no final da década de 1990 e, perpetuam até os dias atuais com programas que buscam levar a tecnologia a todas regiões, aumentar a inserção tecnológica nas escolas públicas e, reescrever a história da qualidade da educação em todos os níveis no Brasil, mas, para isso as mídias devem se apresentarem como avanços na educação e não retrocessos.

\section{REFERÊNCIAS}

[1] KENSKI, Vani Moreira. Educação e tecnologias: o novo ritmo da informação. 6. ed. Campinas: Papirus, 2010.

[2] LEITE, Lígia Silva (coord.). Tecnologia educacional: descubra suas possibilidades na sala de aula. 5. ed. Petrópolis: Vozes, 2010.

[3] PAIS, Luiz Carlos. Educação escolar e as tecnologias da informática. Belo Horizonte: Autêntica, 2008.

[4] MINISTÉRIO DA EDUCAÇÃO. Programa Nacional de Tecnologia Educacional. Brasília, DF: MEC, Secretaria de Educação a Distância, 2009. Disponível em Acesso em: 02 mai.2011.

[5] BRANDÃo, Pollyanna de Araújo Ferreira; CAVALCANTE, Ilane Ferreira. Reflexões acerca do uso das novas tecnologias no processo de formação docente para a educação profissional. Anais do III Colóquio Nacional. Eixo Temático III - Formação de professores para a educação profissional. P. 1-7, 2010. BRASIL. Ministério da Educação (MEC). Secretaria de Ensino Fundamental (SEF). Parâmetros Curriculares Nacionais. Brasília: MEC/SEF, 1998.

[6] BRITO, Glaucia da Silva; PURIFICAÇÃO, Ivonélia da. Educação e novas tecnologias: um repensar. São Paulo: Pearson, 2012.

[7] MARCONI, Marina de Andrade; LAKATOS, Eva Maria. Fundamentos de metodologia científica. 5. ed. São Paulo: Atlas, 2003.

[8] CURY, Lucilene; CAPOBIANCO, Lígia. Princípios da história das tecnologias da informação e comunicação grandes invenções. VIII Encontro Nacional de História da Mídia. Unicentro. Guarapuava-PR, 28 a 30 de abril de 2011.

[9] DAMASCENO, José Alves. O uso das TICS nas aulas de história e estratégias para inclusão digital dos professores. Curitiba-Paraná: Programa de Desenvolvimento Educacional, 2009.

[10] FAGUNDES, Léa. Novo paradigma para a educação. In: COMITÊ GESTOR DA INTERNET NO BRASIL. Pesquisa Sobre o Uso das Tecnologias de Informação e Comunicação no Brasil: TIC Educação 2011. São Paulo: CGI.br, 2012. 
[11] FAVA, Rui. O ensino na sociedade digital. 2012. Disponível em: <http://semesp.org. br/portal/index.php>. Acesso em: 22 maio 2019.

[12] FERNANDES, Elizangela da Rocha; ZITZKE, Valdir Aquino. A evolução da Técnica e o surgimento da tecnologia no contexto econômico e educacional. Anais do III Congresso Internacional de História da UFG/Jataí: Hist'ria e Diversidade Cultural, Textos Completos. 25 a 27 de setembro de 2012.

[13] TAJRA, Sanmya Feitosa. Informática na educação. 6. ed. São Paulo: Érica, 2001.

[14] FERREIRA, Maria Fernanda. O universo das crianças na mídia digital: a experiência de blogs. Anais do I Simpósio de comunicação e tecnologias interativas. 2009.

[15] FREITAS, E. B.; SANTOS, E. A.; PAULA, L. F. A introdução das TICs como ferramenta de ensino-aprendizagem no Ensino Fundamental e Médio. Congresso Ibero-Americano de Ciência, Tecnologia, Inovação e Educação. Buenos Aires- Argentina, 12, 13 e 14 de novembro 2014.

[16] GIL, Antônio Carlos. Como elaborar projetos de pesquisa. 12. ed. São Paulo: Atlas, 2010.

[17] LIMA, Ana Lúcia D’Imério. TIC na educação no Brasil: o acesso vem avançando. E a aprendizagem? In: COMITÊ GESTOR DA INTERNET NO BRASIL. Pesquisa Sobre o Uso das tecnologias de informação e comunicação no Brasil: TIC Educação 2011. São Paulo: CGI.br, 2012.

[18] MAINART, Domingos de A.; SANTOS, Ciro M. A importância da tecnologia no processo ensino-aprendizagem. VII Convibra Administração - Congresso Virtual

[19] MARCONI, Maria de Andrade; LAKATOS, Eva Maria. Fundamentos de metodologia científica. 9. ed. São Paulo: Atlas, 2013.

[20] MORAES, Maria Cândida. Informática educativa no Brasil: uma história vivida, algumas lições aprendidas. Revista Brasileira de Informática na Educação. (SBC- IE, UFSC), n. 01, setembro 1997.

[21] NASCIMENTO, Antonio Dias; HETKOWSKI, Tânia Maria. (Orgs.). Educação e contemporaneidade: pesquisas científicas e tecnológicas. Salvador-Bahia: EDUFBA, 2009.

[22] QUARTIERO, Elisa Maria. Da máquina de ensinar à máquina de aprender: pesquisas em tecnologia educacional. Vertentes. São João Del-Rei. v. 29, p. 51-62, 2007.

[23] RABOY, Mark; SOLERVINCENS, Marcelo. Meios de comunicação. 2006 . Disponível em: <http://vecam.org/article684.html> Acesso em: 02 nov. 2018.

[24] SAVIANI, Demerval. Pedagogia histórica-crítica: primeiras aproximações. Campinas-São Paulo: Autores Associados, 2014

[25] TAJRA, Sanmya Feitosa. Informática na educação: novas ferramentas pedagógicas para o professor na atualidade. 9. ed. rev., atual. e ampl. São Paulo: Érica, 2012.

[26] TAJRA, Sanmya Feitosa. Informática na escola 2. São Paulo: Érica, 2014.

[27] VOSGERAU, Dilmeire Sant'anna Ramos. A tecnologia nas escolas: o papel do gestor neste processo. In: COMITÊ GESTOR DA INTERNET NO BRASIL. Pesquisa Sobre o Uso das Tecnologias de Informação e Comunicação no Brasil: TIC Educação 2011. São Paulo: CGI.br, 2012. 


\section{Capítulo 16}

A implementação de políticas públicas de tecnologias educacionais nas escolas do Município de Paranaguá: Um olhar crítico

Arlane Queiroz Pereira

Eduardo Alberto da Silva

Larissa Costa Souza

Leticia Izabela Ferreira Guimarães Godoi

Lo Ruama Dyenifer Passos de Souza

Luana Carla Bernardo

Raquel Matciulevitz Moraes de Oliveira

Sthefany dos Santos Pereira

Resumo : 0 objetivo central deste artigo consistiu em identificar os programas de tecnologias educacionais inseridos no município de Paranaguá. A metodologia adotada constou de pesquisa documental em sites dos órgãos governamentais, além de pesquisa bibliográfica na literatura da área acadêmica. Também foi realizada pesquisa de campo por meio de realização de entrevista com funcionário da rede municipal de ensino de Paranaguá, com a finalidade de possibilitar o levantamento de dados sobre a inserção das tecnologias no contexto pesquisado. Os resultados permitem comprovar que as políticas públicas de implementação de ferramentas tecnológicas nos espaços escolares do município de Paranaguá têm se revelado positivas, embora permaneçam restritas a ações pontuais que ainda precisam ser melhor exploradas.

Palavras-chave: Tecnologias educacionais. Políticas públicas. Paranaguá. 


\section{INTRODUÇÃO}

As transformações relacionadas à ciência e tecnologia têm provocado mudanças na sociedade em vários aspectos. Tais mudanças refletem na educação e na forma de ensinar. Nesse sentido, a Base Nacional Comum Curricular (BNCC) prevê o uso das tecnologias no processo de ensino e aprendizagem, cabendo, então, ao município implantar políticas que favoreçam a plena atuação do professor em sala. Isso tem sido feito? 0 município de Paranaguá tem implantado políticas públicas de tecnologias educacionais? A partir desses questionamentos, desenvolveu-se essa pesquisa, cujo objetivo foi conhecer os programas de tecnologias educacionais inseridos no município de Paranaguá.

O caminho metodológico percorrido consistiu em realizar pesquisa documental em sites dos órgãos governamentais, além de pesquisa bibliográfica na literatura acadêmica, com vistas a investigar de que forma as tecnologias foram implantadas nas escolas federais e nas escolas estaduais do Paraná. A pesquisa de Moraes (2000) guiou-nos nesse sentido, pois abordou “Informática, Educação e História no Brasil". Para compreender a importância das tecnologias na educação analisou-se as produções acadêmicas sobre esse tema, em que se destacam os estudos de Dowbor (2001), Brito (2009) e Roth (2011). Foi ainda realizada pesquisa de campo, por meio da aplicação de questionário e roteiro de entrevista com funcionários da rede municipal de ensino, com a finalidade de possibilitar o levantamento de dados sobre a inserção das tecnologias no contexto pesquisado. Os estudos de Gil (2002) foram considerados na elaboração deste trabalho, pois as questões foram formuladas no sentido de traduzir os objetivos específicos da pesquisa.

\section{O ENTENDIMENTO DOS AVANÇOS TECNOLOGICOS NA EDUCAÇÃO COMO FERRAMENTA NOS PROCESSOS DE ENSINO APRENDIZAGEM}

Reconhecemos que estamos inseridos em um mundo repleto de tecnologia e que está a todo o momento se reinventando e se desenvolvendo cada dia mais, por esse motivo o ser humano se torna inteiramente conectado e dependente dessa nova ferramenta tecnológica, por estar inserida em todos os momentos do dia a dia.

A utilização das novas tecnologias afeta todos os campos educacionais. Elas encaminham as instituições para a adoção de uma "[...] cultura informática educacional que exige uma reestruturação sensível, não apenas das teorias educacionais, mas também da própria percepção e ação educativa” (KENSKI, 2007, p. 67).

A presença das tecnologias digitais no ambiente escolar, ainda bastante contestada por muitos professores e /ou instituições, representa uma consequência natural da própria conformação da sociedade, permeada por um fluxo constante de informações e artefatos que instigam os sujeitos a buscar o acesso cada vez maior aos recursos tecnológicos disponíveis. Esta realidade interfere diretamente na forma de atuação do professor.

As tecnologias digitais hoje são muitas, acessíveis, instantâneas e podem ser utilizadas para aprender em qualquer lugar, tempo e de múltiplas formas. 0 que faz a diferença não são os aplicativos, mas estarem nas mãos de educadores, gestores (e estudantes) com uma mente aberta e criativa, capaz de encantar, de fazer sonhar, de inspirar. Professores interessantes desenham atividades interessantes, gravam vídeos atraentes. Professores afetivos conseguem comunicar-se de forma acolhedora com seus estudantes através de qualquer aplicativo, plataforma ou rede social. (MORAN, 2017, p.1).

Neste cenário, pode-se dizer que a tecnologia tem um impacto direto sobre a educação, posto que, segundo Dowbor (2001, p.11) “[...] não é uma área em si, mas um processo permanente de construção de pontes entre o mundo da escola e o universo que nos cerca". Assim sendo, para que esse recurso seja melhor explorado, a educação deve trabalhar em conjunto com essa era do mundo digital que só tem a agregar, trazendo novas perspectivas de práticas educativas com o intuito de implementá-las e compreendê-las como uma ferramenta para a construção do conhecimento.

Tanto os professores quanto os alunos devem abrir-se para esse campo, observando e utilizando a tecnologia para seu próprio enriquecimento, deixando de lado a ideia de que os instrumentos digitais servem apenas para os momentos de lazer, diversão e para a praticidade. Em entrevista sobre este tema, Roth afirma que: 
[...] Dominar as novas linguagens, especialmente a da internet, é outro ponto importante e que precisa de atenção. Não basta deixar que as crianças usem a tecnologia em sala de aula. É preciso dominá-la para atribuir novo significado a esse uso. (ROTH, 2011, s/p).

Portanto, faz-se necessário que a tecnologia faça parte do cotidiano dos estudantes, para que esses a tornem um recurso para seu próprio ensino aprendizagem. Nesta perspectiva, o professor precisa estar preparado e inteirado sobre esses recursos, para que possa aproveitá-los como fonte enriquecedora de sua prática, pois por se tratar de uma ferramenta atual e que chama atenção acaba trazendo outra perspectiva para os discentes dessa geração tecnológica. Entende-se que a tecnologia hoje é a nossa realidade educacional, haja vista que os processos pedagógicos a partir desse avanço permitem que haja uma reconfiguração na sociedade.

A tecnologia está cada vez mais abrindo portas para um mundo digital, de modo que é urgente e necessário que adentre o ambiente escolar e se articule com novas concepções de ensinar e aprender. Embora em muitas escolas existam computadores muitas vezes sucateados, ou até mesmo trancados em laboratórios, limitando o acesso aos que realmente deveriam usar, é preciso buscar uma maior autonomia na atuação dos professores, fazendo que interajam com os alunos, de forma que a utilização dos meios tecnológicos seja direcionados ao pleno aprendizado. As escolas estão em processo de construção para se emancipar, caminham para construir seus saberes e criar sistemas de conhecimento a partir do agir pedagógico.

No entendimento de que é primordial reconstruir o mundo digital na educação, Fóglia (2007) supõe que há uma tradição de verificação humanística, a qual pode conduzir a uma crescente autonomia. Embora a tecnologia possa ser concebida como um meio de interação entre a escola e os alunos, não se configura uma ferramenta suficiente para solucionar todas as dificuldades da educação, porém, quando se une com a prática social e o contato com a humanidade, ajuda na reconstrução de novos conhecimentos. É possível, ainda, aproveitar os frutos adquiridos no desenvolvimento de uma crítica cultural para problematizar o uso das tecnologias no âmbito escolar

É importante entender a reflexão e ação a respeito das tecnologias, pois se compreende que a prática social demanda condições humanas como moral, ética, estética e política. Portanto, as ações pedagógicas precisam se concentrar aos interesses dos professores e alunos (FÓGLIA, 2007).

Por fim, é importante ressaltar que os profissionais da educação concordam que o uso da tecnologia nas aulas auxilia no processo de ensino e aprendizagem. Para Brito (2009), a tecnologia constitui parte integrante da vida humana e está presente em toda parte. Isto equivale a afirmar que o professor, ao valerse de recursos tecnológicos, pode tornar sua aula mais interessante e proporcionar a construção de novos conhecimentos para o aluno. No entanto, é preciso que o Estado invista em mais recursos tecnológicos nas escolas e na formação continuada dos professores, pois de nada adianta proporcionar os recursos e não dar uma capacitação para a utilização das tecnologias. A tecnologia por si só não garante o conhecimento do aluno, mas facilita o aprendizado, pois uma aula com apresentação de imagens, por meio do data show ou uma aula de pesquisa, por meio da internet, desperta a curiosidade do aluno por ser algo novo. Portanto, a utilização de tecnologia na educação pode ser algo inovador, que desperta o interesse dos alunos, mas é preciso ter investimento do Estado nas escolas públicas e profissionais capacitados para trabalharem com esses novos recursos.

\section{BREVE HISTÓRICO DO DESENVOLVIMENTO DE TECNOLOGIAS EDUCACIONAIS NO BRASIL}

A implementação de tecnologias relacionadas à informática no Brasil, desde a sua origem, esteve relacionada ao interesse dos militares. Sua vinculação com a educação ocorreu a partir do momento em que surge a necessidade de mão de obra especializada nesse setor. Em sua pesquisa sobre Informática, Educação e História no Brasil, Moraes (2000) descreve que o regime militar de 1964 orientou essas políticas com o projeto "Brasil Grande Potência” e a Marinha brasileira efetivou essas políticas ao comprar fragatas inglesas com equipamentos eletrônicos e elaborar um projeto de protótipo de computador no próprio país de forma a garantir o controle bélico das embarcações. Com isso, houve a mobilização de órgãos e agências para financiar a construção do protótipo.

Surge em 1972 a Coordenação de Assessoria ao Processamento Eletrônico (CAPRE), com “[...] a finalidade de adotar e propor medidas visando à racionalização dos investimentos governamentais no setor e à elevação da produtividade na utilização dos equipamentos de processamento de dados instalados e a instalar" (BRASIL, 1972). 
De 1972 até os dias atuais, Moraes (2000) informa que foram criados 10 projetos relacionando tecnologias e educação, são eles; a Secretaria Especial de Informática (SEI) em 1979; o Centro de Informática do MEC (Ministério da Educação) (CENIFOR) em 1982; o Núcleo Interdisciplinar de Informática Aplicada à Educação/Universidade de Campinas (NIED/UNICAMP) e o Projeto Educação com computador (EDUCOM) em 1983; o Ministério de Ciência e Tecnologia (MCT) em 1985; o Comitê Assessor de Informática na Educação de 1ํ e 2o graus em 1986; o Projeto Formar em 1987; o Programa Nacional de Informática Educativa (PRONINFE) em 1989 e o mais recente é o Programa Nacional de Tecnologia Educacional (ProInfo),

Foi criado pelo Ministério da Educação, em 1997, para promover o uso da tecnologia como ferramenta de enriquecimento pedagógico no ensino público fundamental e médio. A partir de 12 de dezembro de 2007, mediante a criação do Decreto ${ }^{\circ}$ 6.300, foi reestruturado e passou a ter o objetivo de promover o uso pedagógico das tecnologias de informação e comunicação nas redes públicas de educação básica (BRASIL, 2007, s/p).

O Programa Nacional de Tecnologia Educacional atualmente proporciona duas ações direcionadas a estudantes e professores do ensino fundamental e médio das redes de ensino públicas, são ações voltadas para o uso didático-pedagógico das Tecnologias da Informação e Comunicação (TIC) no cotidiano escolar, articulado ao fornecimento de equipamentos tecnológicos e digitais. Uma dessas ações é o Programa "Um Computador por Aluno" (PROUCA), que foi Instituído pela Lei no 12.249, de 14 de junho de 2010, que tem por objetivo estimular o uso de das tecnologias com a distribuição de computadores portáteis (laptops) para os alunos da rede de ensino pública, agregando dessa forma aos laboratórios de informática e a disponibilização desses para objetivos educacionais com incentivo e estímulo ao uso pedagógico da informática (BRASIL, 2010).

Outra ação promovida foi a de distribuição de tablets, o MEC transferiu recursos para vinte e quatro Estados e Distrito Federal para a compra de 382.317 equipamentos, destinados às escolas públicas, 53 coordenadores receberam curso de formação para mais tarde repassarem aos professores de cada Estado participante. Além de diversas especificidades técnicas, o tablet pode ser conectado a televisores, monitores e projetores, podendo assim ser utilizados para apresentações em sala e outros ambientes (BRASIL, 2010).

\subsection{BREVE HISTÓRICO DO DESENVOLVIMENTO DE TECNOLOGIAS EDUCACIONAIS NO ESTADO DO PARANÁ}

O primeiro passo em relação à informática na educação no Paraná foi dado no ano de 1985, pelo Plano Estadual de Educação do Paraná. Em 1987, foi criado um Centro de Informática na Educação (CIED), na cidade de Maringá, que ficou como polo de investigações em informática da educação. No mesmo ano da criação do CIED, foi criado Comitês de Assessoramento de Informática Educativa, com isso houve resultados para criação de mais programas e projetos relacionados à informática na Educação, como: Projeto Formar (1987, 1989 e 1992) e Concursos de Softwares Educativos (1987 a 1989).

No ano de 1991, foi instituída a formação por meio do Programa Televisivo Salto para o futuro e em 1997, foram criados outros programas televisivos, sendo assim efetivado como Programa de formação, pelo Ministério da Educação (MEC). Em 1996, foi criada a Secretaria de Educação à Distância (SEED) que ficou responsável pela implantação da política de educação a distância.

Em 1996, surgiu a proposta do Programa Nacional de Informática na Educação, o ProInfo, com o objetivo de implantar o uso do computador nas escolas públicas estaduais e municipais e também criar Núcleos de Tecnologia Educacional para capacitar e ensinar o professor a utilizar essa ferramenta como instrumento pedagógico. Estava previsto pelo ProInfo instalar 13 Núcleos de Tecnologia Educacional pelo Estado do Paraná, em 1997/1998 foram instalados 6 NTEs, em 1999 mais 6 NTEs e em 2000 se instalou o 13№ NTEs. Em todos os Núcleos de Tecnologia Educacional, existiam profissionais da educação para formar o grupo de multiplicadores, auxiliando no processo de formação continuada para a utilização das tecnologias na escola (CANTINI, 2008).

Este mesmo autor menciona que em 1996 foi criado mais um projeto nas escolas estaduais, o Programa de Extensão, Melhoria e Inovação do Ensino Médio do Paraná, o Proem, tendo sido projetadas reformas nas escolas públicas estaduais, bem como a construção de bibliotecas e laboratórios de informática (CANTINI, 2008). 
Fóglia (2007, p. 8) sinaliza que:

Utilizar novas tecnologias com responsabilidade é um dos caminhos que o governo está apostando para a melhoria significativa da educação paranaense. Nesse sentido, caminhar do uso instrumental de tecnologias para a utilização consciente e reflexiva focada no desenvolvimento da cultura e filosofia de uso do "Software Livre", por exemplo, é um dos pilares das ações de formação continuada, tendo como elemento norteador desta ação as Diretrizes Curriculares do Estado do Paraná. Outra preocupação que não pode ficar de fora das discussões sobre a utilização das novas tecnologias é a que se refere à necessidade de se desenvolver a capacidade de realizar uma leitura crítica sobre as mensagens e imagens veiculadas por tais tecnologias.

Nos dias atuais, a secretaria procura sempre inovar através das tecnologias, buscando novos meios para a educação incluindo capacitações para professores de novas tecnologias e comunicações. O Centro de Excelência em Tecnologia Educacional do Paraná (CETEPAR) é responsável pela implementação de políticas públicas, onde desencadeia um processo de inovação, articulando a educação com a tecnologia. Com isso são disponibilizados equipamentos para as escolas possibilitando produções de novos conteúdos, respeitando as diretrizes curriculares propostas pela SEED.

Dentre esses projetos de inovações, pode-se citar a robótica que também foi apresentada como umas das principais revoluções, criada pelo Departamento de Políticas e Tecnologias Educacionais (DPTE) da SEED, que oferta programações diferenciadas para professores, alunos e toda a comunidade escolar.

Cantini (2008) pondera que existem ainda muitas barreiras a serem transpostas no processo de formação continuada dos professores das escolas para uso das tecnologias, dentre elas pode ser destacada a falta de incentivo no processo de progressão de carreira aos professores que implementarem o uso de tecnologias na sua prática pedagógica, disponibilidade dos professores para participar do processo de formação continuada em sua jornada de trabalho, pois em sua hora atividade a prioridade é dada ao preparo e correção de avaliações.

\subsection{BREVE HISTÓRICO DO DESENVOLVIMENTO DE TECNOLOGIAS EDUCACIONAIS NO MUNICÍPIO DE PARANAGUÁ}

O primeiro investimento em tecnologias para a educação no município de Paranaguá foi um incentivo do estado do Paraná no governo de Jaime Lerner (1995 - 2003), inaugurando o laboratório de informática do município, contemplando o colégio Estadual “José Bonifácio" e posteriormente os colégios "Alberto Gomes Veiga” e Instituto Estadual de Educação “Dr. Caetano Munhoz da Rocha”, com a intenção de ofertar cursos técnicos nas áreas de Logística, Vendas e Técnica de Portos, no ano de 1999. Posteriormente ao ano de 1999, apenas em 2008 foram feitas implementações de tecnologias visando à educação (FOLHA LITORAL, 2013).

A implementação do ano de 2008 deu-se na perspectiva de subsídio municipal após um pregão que financiou a compra de computadores da marca Positivo, de memória DDR-2. Complementando a iniciativa, no ano de 2012, foram comprados novos computadores Positivo, com memória DDR-3, que estão em uso até o momento (2019) nas escolas atendidas pelo município.

No ano de 2015, houve a aquisição de 727 computadores, 78 notebooks, assim como centenas de equipamentos, roteadores, entre outros itens, pela quantia de mais de $\mathrm{R} \$ 2$ milhões. 0 processo de implementação de tais equipamentos foi mediado no governo de Edison Kersten, prefeito na época (FOLHA LITORAL, 2019).

Com a intenção de disponibilizar internet nas instituições escolares em consonância com a implementação dos equipamentos adquiridos, realizou-se a contratação de rede banda larga pelos serviços da empresa "Oi" (Companhia de Telecomunicações), que confirmou vínculo até o ano de 2018. No ano de 2018, o município migrou de serviço, fazendo uso até o momento (2019) da internet fornecida pela empresa Copel (Companhia Paranaense de Energia), que aprimorou a disponibilidade da internet na utilização de fibra óptica (FOLHA LITORAL, 2019). .

Ainda em 2018, a prefeitura de Paranaguá procedeu à entrega de mais de 150 mesas digitais para serem utilizadas nas escolas, tendo em vista aprimorar o uso das tecnologias no processo de ensino aprendizagem e tendo como discurso o envolvimento com pedagogias de cunho lúdico. 0 objetivo da mesa digital consistia 
em auxiliar os professores em sua prática pedagógica, atuando como uma ferramenta lúdica da qual contribuiria no desenvolvimento das habilidades cognitivas do educando (FOLHA LITORAL, 2019).

A prioridade para a implementação da mesa visualizava a necessidade de equipar as salas de AEE (Atendimento Educacional Especializado). Neste sentido, apesar de as mesas digitais terem sido adquiridas pensando no ensino aprendizagem na sala de recursos multifuncionais, de atendimento especializado, as escolas que não atuam com a modalidade de educação especial também adquiriram o equipamento interativo, na perspectiva de incentivar a atuação com o instrumento digital enquanto ferramenta e recurso de ensino aprendizagem, para crianças de 3 a 8 anos de idade, o que contempla Educação Infantil e Ensino Fundamental l - anos iniciais (FOLHA LITORAL, 2019).

A Secretaria de Educação do Município de Paranaguá, protagonista no processo de implementação e desenvolvimento de projetos em relação a Tecnologias da Educação, relatou que houve uma investigação para saber o posicionamento das escolas em relação a implementação das mesas digitais, antes que houvesse a efetivação da compra. Na ocasião, os representantes das escolas concordaram com a implementação, sabendo que haveria a necessidade da disponibilidade de um docente para receber a capacitação do uso das mesas, e, por consequência, esses docentes, capacitados, seriam os responsáveis por repassar as técnicas de manuseios para os demais docentes da equipe escolar onde atuavam (FOLHA LITORAL, 2019).

Neste sentido, a capacitação focou na explanação do manuseio da mesa digital, enquanto, a tarefa de explorar os conteúdos da mesa digital ficou sob a responsabilidade dos profissionais, assim como pensar em meios de sua utilização dentro das suas propostas desenvolvidas para o ensino aprendizagem.

Após os processos de capacitação e distribuição das mesas, não houve uma pesquisa por parte da Secretaria da Educação do Município para saber sobre o uso das mesas nas escolas. Até o momento não houve feedback investigando se houve, efetivamente ou não, a utilização das mesas como instrumento auxiliador no processo de ensino aprendizagem. Ou seja, ainda não se sabe se alcançaram o objetivo de utilizar as mesas como ferramenta lúdica, e como assessora - principalmente - na modalidade de Educação Especial (FOLHA LITORAL, 2019).

Na ocasião do evento de inauguração das mesas, no Ginásio de Esportes “Joaquim Tramujas", o atual prefeito da cidade, Marcelo Roque, reiterou para o jornal Folha do Litoral que:

Investir em educação é investir no nosso futuro. As prioridades de qualquer gestor devem ser sempre a saúde, a segurança e a educação. Não podemos fugir dessas três pastas tão importantes. Tenho certeza de que o IDEB vai aumentar no ano que vem, pela qualificação dos nossos profissionais e a educação. Não podemos fugir dessas três pastas tão importantes. Tenho certeza de que o IDEB vai aumentar no ano que vem, pela qualificação dos nossos profissionais e a infraestrutura que estamos dando (FOLHA LITORAL, 2019).

O investimento em educação se dá, também, através da implementação de projetos, no entanto, há de repensar a forma como tais projetos são mediados no processo de execução. Assim como as mesas digitais, a implementação dos computadores e de internet, são investimentos sustentados por projetos que significam uma intenção, no entanto, não são executadas investigações e acompanhamentos para saber se os objetivos dos projetos estão realmente sendo alcançados, o que ocasiona uma situação de esquecimento dos recursos disponibilizados.

Em síntese, há duas situações conflituosas nas implementações e investimento em tecnologias educacionais no município de Paranaguá. A primeira é a efetiva capacitação dos profissionais que farão uso dos recursos disponibilizados. Capacitação que deveria ser análoga ao processo de ensino aprendizagem, refletindo no uso dos recursos como auxiliador do ensino, e não apenas no manuseio técnico dos materiais. A segunda situação conflituosa refere-se ao acompanhamento da utilização dos recursos disponibilizados, o qual não é feito de maneira eficaz. A falta da investigação reflete no esquecimento dos recursos disponibilizados, o que ocasiona a sensação de que não há investimentos.

\section{ANÁLISE DO USO DE TECNOLOGIAS EDUCACIONAIS NO MUNICÍPIO DE PARANAGUÁ}

Na intenção de buscar mais informações a respeito da implementação de Tecnologias Educacionais no Município de Paranaguá, foi elaborado um questionário destinado à Secretaria da Educação do Município 
(SEMEDI). À época de realização da pesquisa, a responsável por responder as perguntas era membro da Secretaria, atuando no departamento de coordenação dos assuntos voltados à implementação de recursos educacionais no Município.

As perguntas elaboradas tiveram por objetivo mapear informações quantitativas de atendimento de escolas municipais, investigar o desenvolvimento de projetos destinados ao incentivo de tecnologias educacionais, compreender o processo de aquisição das mesas interativas e os procedimentos posteriores à compra, no que diz respeito à capacitação dos professores para a utilização das mesas e o incentivo ou determinação de projetos pedagógicos envolvidos a criação de propostas lúdicas de atuação junto às mesas.

Respondendo a primeira pergunta, a respeito da rede de atendimento da Secretaria, constatou-se que o município atende 33 (trinta e três) escolas urbanas, 5 (cinco) escolas do campo e 23 (vinte e três) CMEIs. Pensando na aquisição das mesas interativas, proposta mais recente de implementação de tecnologias educacionais, foi respondido que os CMEIS tiveram menor prioridade na aquisição, em consequência, por se tratar de uma proposta pedagógica de atendimento especializado, as mesas foram disponibilizadas em maior quantidade em escolas que atendem a modalidade de Educação Especial e as escolas de Ensino Integral.

Ainda em outra questão do roteiro da entrevista, foi informado que o número de mesas adquiridas estaria no site da prefeitura, no Edital no 084/2017. No subtítulo terceiro do edital, no que diz respeito "Do preço e da dotação orçamentária" (PARANAGUÁ, 2017, p. 5) é possível visualizar a quantidade de mesas interativas adquiridas no $1^{\circ}$ e $2^{\underline{o}}$ lote, e os valores.

No primeiro lote o número total de mesas interativas adquiridas soma a quantidade de 130 (cento e trinta), no segundo lote o total de mesas interativas adquiridas somam 390 (trezentos e noventa). 0 valor total gasto no primeiro lote para a aquisição foi de $\mathrm{R} \$$ 1.867.667,10 (um milhão oitocentos e sessenta e sete mil e seiscentos e sessenta e sete e dez centavos), no segundo lote o valor total gasto foi de $\mathrm{R} \$ 5.603 .001,30$ (Cinco milhões e seiscentos e três mil e um e trinta centavos). Somando a quantidade total de mesas adquiridas obtém-se o número de 520 (quinhentos e vinte), onde o valor de cada mesa é o de $\mathrm{R} \$ 14.366,67$ (quatorze mil trezentos e sessenta e seis e sessenta e sete centavos) (PARANAGUÁ, 2017).

No parágrafo de IV conclusão, é esclarecido que:

Assim sendo, o total de mesas a serem adquiridas para implantação das salas interativas em todas as Escolas Municipais e CMEIS's é de 520 unidades. Deste modo, pretende-se deixar transparente a forma organizacional que esta Secretaria Municipal de Educação e Ensino Integral construiu a logística de distribuição da implantação das salas e espaços interativos por Instituição de Ensino e número de alunos. Para concluir, destacase que o objetivo da aquisição da mesa interativa é integrar no cotidiano das escolas os jogos interativos que trabalham diversas disciplinas no aprendizado infantil, tornando o processo de ensino e aprendizagem mais divertido e prazeroso, como uma brincadeira, para incentivar não só o gosto pelo estudo e pela escola, mas também para estimular a interação entre os estudantes e entre os professores. A Secretaria Municipal de Educação e Ensino Integral, com esta iniciativa pretende aproximar a ludopedagogia dos processos de aprendizados. (PARANAGUÁ, 2017, p.41).

Após a aquisição das 520 mesas interativas, houve a distribuição e repasse para as escolas, tendo prioridade as escolas de ensino integral e aquelas que realizam atendimento especializado em Educação Especial. É interessante ressaltar que entre os critérios para a distribuição levou-se em consideração o número de estudantes por escola. As escolas que atendem um número maior que 300 (trezentos) estudantes receberam 10 (dez) mesas, destinando duas mesas para as salas de atendimento especializado e as restantes para as salas interativas. As escolas com o número menor de 300 (trezentos) estudantes, receberam cada uma 7 (sete) mesas, sendo duas mesas para o atendimento especializado (PARANAGUÁ, 2017).

Em paralelo ao processo de aquisição e distribuição das mesas foi promovida, pela SEMEDI, a formação para a utilização da ferramenta. A formação teve como enfoque instruir a utilização técnica do material lúdico, explorando suas capacidades para a atuação. Na entrevista, foi informado que um professor por escola ficou 
responsável por participar da formação e repassar os conhecimentos ao corpo docente da instituição em que atuava. Neste sentido, ficou por critério da escola escolher o professor que receberia a formação.

A respeito da fiscalização da utilização das mesas, e o feedback das escolas e dos professores em relação ao uso do material como ferramenta pedagógica lúdica de recursos para o ensino aprendizagem, foi respondido que ainda não há um retorno nem positivo nem negativo em relação à utilidade e aproveitamento. Ainda foi salientado pela entrevistada que o feedback será mediado pela empresa contratada na compra da mesa.

No esclarecimento sobre os projetos pedagógicos envolvidos para a utilização da mesa como recurso didático-educativo-lúdico, foi respondido que as escolas, no exercício de sua autonomia, ficaram responsáveis por desenvolver, a partir do planejamento e proposta política pedagógica subscrita do PPP (Projeto Político Pedagógico), a prioridade da utilização das mesas em consonância com a atuação instrutiva no desenvolver do decurso pedagógico.

No que tange ao desenvolvimento de propostas voltadas ao incentivo e introdução de novas tecnologias educacionais na rede municipal, foi respondido que o departamento de Tecnologias Educacionais é o responsável por trazer novas propostas e articular a execução. Atualmente (2019), o projeto arquitetado de implementação de tecnologias tem sido o de aprimoramento da rede banda larga disponibilizada nas escolas do município, tendo em vista o aumento da velocidade da internet já em serviço.

\section{CONSIDERAÇÕES FINAIS}

A elaboração deste artigo teve como objetivo geral identificar os programas de tecnologias educacionais inseridos no município de Paranaguá.

A pesquisa bibliográfica realizada permitiu comprovar que as tecnologias educacionais assumem especial importância no contexto da sociedade contemporânea, imersa em uma extensa rede de tecidos sociais mediados pelos artefatos tecnológicos de toda espécie.

Deste modo, discutir a inserção das tecnologias no ambiente escolar mostra-se bastante oportuno, na medida em que se trata de representar uma consequência natural da própria conformação da sociedade, em que os sujeitos encontram-se imersos em redes sociais das mais variadas, valendo-se de dispositivos móveis para a execução das tarefas do cotidiano, das mais simples às mais complexas.

Entende-se que a escola, como agência social por excelência, não pode se distanciar da realidade vivenciada por seus alunos. Deste modo, a realidade interfere diretamente na forma de atuação do professor, que precisa também aprimorar seus conhecimentos para fazer frente ao trabalho com os recursos tecnológicos que estão adentrando o ambiente escolar.

Quando se abordou a implementação das tecnologias educacionais no Brasil, foram encontrados elementos que confirmam a criação, a partir da década de 1970, da Secretaria Especial de Informática (SEI) e outros centros de apoio à informática aplicada à educação. 0 próprio Ministério de Ciência e Tecnologia (MCT), criado em 1985, contribuiu para disseminar programas como o ProInfo (Programa Nacional de Tecnologia Educacional).

No âmbito regional, o estado do Paraná conta com o Centro de Excelência em Tecnologia Educacional do Paraná (CETEPAR), responsável pela implementação de políticas públicas, visando promover a articulação entre a educação e a tecnologia.

Por sua vez, no município de Paranaguá - foco da pesquisa que deu origem a este artigo, a partir de 2003 houve iniciativas voltadas para a inserção das tecnologias na escola, como a criação de laboratórios de Informática, manutenção de Internet em todas as instituições de ensino, e, mais recentemente, a aquisição de mesas digitais com a finalidade de aprimorar o uso das tecnologias no processo de ensino aprendizagem por meio de atividades lúdicas.

Quando se buscou compreender a forma pela qual se concretizou a implementação dos recursos tecnológicos educacionais no município, foram encontrados subsídios junto a funcionários da Secretaria da Educação do Município (SEMEDI).

Em primeiro plano, obteve-se a confirmação de que a inserção tecnológica no âmbito escolar é uma preocupação do Executivo municipal. Ao investigar o desenvolvimento de projetos destinados ao incentivo de tecnologias educacionais, foi dada ênfase no processo de aquisição das mesas interativas e os procedimentos posteriores à compra, no que diz respeito à capacitação dos professores para seu efetivo 
uso. Foi possível evidenciar ainda uma preocupação com a efetiva utilização do equipamento, vinculada aos objetivos do processo ensino aprendizagem da clientela a que se destina.

Foi mencionada ainda a adequação da rede de banda larga disponível nas instituições de ensino, como pressuposto para garantir a efetividade das ações que permitem o uso de equipamentos tecnológicos com maior rapidez e eficácia.

De forma geral, constatou-se que as políticas públicas de implementação de ferramentas tecnológicas nos espaços escolares do município de Paranaguá têm se revelado positivas em muitos aspectos, embora permaneçam restritas a ações pontuais que ainda precisam ser melhor exploradas, observando a capacitação efetiva dos professores da rede e a construção mais planejada de projetos pedagógicos que tornem o conhecimento potencializado pelas ferramentas tecnológicas mais eficazes.

Nesta perspectiva, deve-se sugerir, para futuras pesquisas, a ampliação da abrangência da pesquisa para instituições da rede estadual de ensino, além de aplicação de pesquisa de campo junto a professores, pedagogos e gestores, visando identificar as dificuldades no uso de tais equipamentos, bem como a avaliação dos resultados educacionais percebidos.

\section{REFERÊNCIAS}

[1] BRASIL. Decreto no 70.370. Cria a Comissão de Coordenação das Atividades de Processamento Eletrônico, e dá outras providências. Diário Oficial da União - Seção 1. Brasília: DF, 6 abr.1972. Disponível em: <https://www2.camara.leg.br/legin/fed/decret/1970-1979/decreto-70370-5-abril-1972-418827publicacaooriginal-1-pe.html> Acesso em 22 set. 2019.

[2] BRASIL. Decreto no 6.300. Dispõe sobre o Programa Nacional de Tecnologia Educacional - ProInfo. Diário Oficial da República Federativa do Brasil. Brasília: DF, 13 dez. 2007. Disponível em: <http://www.planalto.gov.br/ccivil_03/_ato2007-2010/2007/decreto/d6300.htm >. Acesso em: 22 set. 2019.

[3] BRASIL, 2010. Lei no 12.249, de 11 de junho de 2010. Cria o Programa Um Computador por Aluno. Brasília, DF, Jun, 2010. Disponível em: <http://www.planalto.gov.br/ccivil_03/_Ato2007-2010/2010/Lei/L12249.htm. Acesso em: 16 out. 2019.

[4] BRASIL. Programa Nacional de Informação na Educação. PROINFO. Disponível em: <http://www.fnde.gov.br/index.php/programas/proinfo> Acesso em: 16 out. 2019.

[5] BRITO, A. C. A. G. et al. Um Olhar sobre Educação: uma abordagem a partir das novas tecnologias. In: Revista Digital Pandora Brasil no 9. 2009.

[6] CANTINI, Marcos César. Políticas Públicas e Formação de Professores na Área de Tecnologias de Informação e Comunicação - TIC na Rede Pública Estadual de Ensino do Paraná. Dissertação ( Mestrado em Educação) Curitiba: PUC, 2008.

[7] DOWBOR, Ladislau. Tecnologias do Conhecimento: os desafios da educação. Petrópolis/RJ: Editora Vozes Ltda., 2001.

[8] FOGLIA, Eliane. O uso de novas tecnologias como política pública na educação: A formação docente em questão no Estado $\quad$ do $\quad$ Paraná. $2007 . \quad$ Disponível em: http://www.gestaoescolar.diaadia.pr.gov.br/arquivos/File/producoes_pde/artigo_eliane_foglia.pdf> . Acesso em: 26 set. 2019.

[9] FOLHA LITORAL. Desde 2013 prefeitura estruturou setor de educação em Paranaguá. Disponível em: https://folhadolitoral.com.br/educacao/desde-2013-prefeitura-estruturou-setor-de-educacao-emparanagua/\#.XYwccEZKiUl. Acesso em: 25 de setembro de 2019.

[10] FOLHA LITORAL. Prefeitura entrega mais de 150 mesas digitais para as escolas do município. Disponível em: https://folhadolitoral.com.br/educacao/prefeitura-entrega-mais-150-mesas-digitais-para-as-escolas-domunicipio/\#.XYwexEZKiUl. Acesso em 25 de Setembro de 2019.

[11] GIL, Antônio Carlos. Como elaborar projetos de pesquisa. 4. ed. São Paulo: Atlas, 2002.

[12] HABOWSKI, Adilson Cristiano, CONTE, Elaine e TREVISAN, Amarildo Luiz. Por uma Cultura Reconstrutiva dos Sentidos das Tecnologias na Educação. Educ. Soc., Campinas, v.40, e0218349, 2019.

[13] KENSKI, Vani Moreira. Educação e tecnologias. 3. ed. Campinas: Papirus, 2007.

[14] MEC. Programa nacional de informação na educação. PROINFO. Disponível em: <http://www.fnde.gov.br/index.php/acesso-a-informacao/institucional/area

[15] -de-imprensa/noticias/item/3917-ministro-entrega-tablets-e-tem-in\%C3\%ADcio-aforma\%C3\%A7\%C3\%A3/o-de-coordenadores. Acesso em: 16 out. 2019. 
[16] MORAES, Raquel de Almeida. Informática, educação e história no Brasil. Revista Conecta, v. 3, 2000. Disponível em: https://cutt.ly/Qk0vPR2. Acesso em: 21 set. 2019-09-21.

[17] MORAN, José. Tecnologias digitais para uma aprendizagem ativa e inovadora. Blog, 04 jul. 2011. Disponível em: encurtador.com.br/lAHL2. Acesso em: 16, fev, 2021.

[18] PARANÁ. Diretrizes para o uso de tecnologias educacionais / Secretaria de Estado da Educação. Superintendência da Educação. Diretoria de Tecnologias Educacionais. - Curitiba: SEED - Pr, 2010. Disponível em: http://portaldoprofessor.mec.gov.br/storage/materiais/0000015327.pdf>. Acesso em: 26 set. 2019.

[19] PARANÁ. Inovações tecnológicas da Seed são apresentadas em evento internacional / Secretaria de Estado da Educação. $16 / 05 / 2019 . \quad$ Disponível em: http://www.educacao.pr.gov.br/modules/noticias/article.php?storyid=8205\&tit=Inovacoes-tecnologicas-daSeed-sao-apresentadas-em-evento-internacional-> Acesso em: 26 set. 2019.

[20] PARANAGUA, Município. Edital do Pregão eletrônico no 084/2017: Registro de Preços no 064/2017. Disponível em:

[21] http://www.paranagua.pr.gov.br/lic.php?licitacao_id=345. Acesso em: 10 de Outubro de 2019.

[22] ROTH, Martina. Revista Nova Escola. Martina Roth fala sobre educação e tecnologia. Disponível em:https://novaescola.org.br/conteudo/904/martina-roth-fala-sobre-educacao-e-tecnologia. Novembro, 2011. Acesso em setembro, 2019. 


\title{
Capítulo 17
}

\section{As TIC no ensino de Física: Relato de experiência com os conteúdos de ótica}

\author{
Ruth Brito de Figueiredo Melo \\ Pedro Steinmüller Pimentel \\ José Edielson da Silva Neves \\ Gyovanna Kelly Matias do Nascimento \\ Deivyson Anderson Silva Candido \\ Olavio Vinícios Barbosa
}

Resumo: Vivemos em uma sociedade em que os avanços tecnológicos são notáveis, trazendo mudanças significativas, inclusive no contexto educacional. Para isso, autores como Filho (2010), Moran (2007), Kenski (2007), Medeiros e Medeiros (2002) e Silva (2001), defendem que simulações computacionais e o uso das TIC (Tecnologias de Informação e Comunicação) devem ter mais inserções no ensino. Nesse contexto, o simulador PhET, pode ser utilizado, proporcionando uma visão diferente para os alunos na compreensão dos conceitos físicos relacionados à ótica e proporcionando um entendimento mais significativo, além disso, melhorando a interação entre os alunos e o próprio docente. Sendo assim, torna-se uma ferramenta viável utilizá-lo como recurso didático no processo de ensino e aprendizagem em sala de aula. Diante disto, esta proposta tem como objetivo relatar uma experiência vivenciada em âmbito escolar, através da utilização do simulador PhET nos conteúdos de ótica, com uma turma de $2^{\circ}$ ano do ensino médio regular, pertencente à uma escola estadual, situada na cidade de Campina Grande - PB. Através das observações feitas, pode-se detectar que os alunos ficaram mais motivados em participar das aulas, bem como relataram sentir uma maior facilidade na compreensão dos conceitos físicos ministrados com a utilização do simulador.

Palavras-chave: Tecnologia de Informação e Comunicação; Simulador; Ensino de Física; Ótica; Phet. 


\section{INTRODUÇÃO}

As TIC (tecnologias de informação e comunicação) fazem parte do cotidiano das pessoas, em especial dos jovens, os quais, inseridos nesse contexto, partilham informações, interagem com outras pessoas, jogam e assistem a vídeos online, ouvem músicas e navegam em redes sociais. Apesar de boa parte do acesso ao computador, estarem relacionados ao entretenimento, muitos jovens se conectam também para buscar informações e se manterem atualizados.

Fora da escola, os professores e alunos estão ligados diretamente e indiretamente com as tecnologias que se tornam cada vez mais avançadas, sendo participativos em diversas atividades, porém, não utilizam ou não conseguem introduzi-las de forma significativa no contexto educacional.

O uso das TIC apresenta desafios e possibilidades para seu planejamento e inserção no processo de ensino e aprendizagem. Entre os desafios enfrentados para aplicação desta abordagem metodológica, encontramse a falta de compreensão do uso das tecnologias por parte dos docentes e a capacitação na área, falta de recursos e estruturas mínimas nas escolas necessárias para o efetivo uso das TIC.

Os recursos tecnológicos estão se disseminando de forma acelerada, gerando mudanças na sociedade. Moura (2016) comenta que a sociedade está imersa ao mundo tecnológico e que devemos usá-las como aliada para facilitar e ajudar no processo de ensino e aprendizagem, já que os jovens estudantes estão numa era digital, com fácil acesso aos celulares, tablets e computadores que são importantes nos dias atuais, sendo a principal atividade a comunicação.

As dificuldades no ensino da Física são diversas e discutidas por vários teóricos, inclusive no ensino de ótica com a falta de materiais didático experimental, inexperiência dos professores com utilização de experimentos e falta de estrutura das escolas para atender as demandas tecnológicas são fatores que favorecem uma aula tradicional e sem inovações didáticas.

Nesse sentido, Costa e Barros (2015) enfatiza que a Física se caracteriza como, na maioria dos casos, a ausência do laboratório de ciências, pela formação docente descontextualizada, pela indisponibilidade de recursos tecnológicos e pela desvalorização da carreira docente.

A ótica é um dos conteúdos relevantes da Física no Ensino Médio, em que vários experimentos e simulações relacionados aos fenômenos óticos são abrangentes e que relacionam com aplicações do cotidiano. Com isso, comumente é transmitido para os alunos de maneira matematizada, sem nenhuma explicação ou contextualização de como se chegou ao conhecimento atualmente aceito, e quais aplicações possíveis; o ensino geralmente apresenta-se tradicionalista, no qual os alunos memorizam temporariamente as equações e conceitos para serem aplicadas em exercícios e avaliações.

Dentro deste contexto, o objetivo deste estudo foi o desenvolvimento e aplicação de uma proposta didática para a compreensão dos conceitos físicos relacionados a ótica, utilizando o simulador PhET, por meio de simulações computacionais, em uma turma do $2^{2}$ ano do Ensino Médio de uma escola pública em Campina Grande - PB.

\section{REFERENCIAL TEÓRICO}

O simulador é uma ferramenta de grande potencialidade para o processo de ensino-aprendizagem da Física nas escolas, uma vez que oportuniza aos estudantes observar fenômenos e assimilar conceitos com aplicações computacionais, no qual torna-se uma tarefa árdua sem a utilização deste recurso tecnológico. Para Zara, (2011) as simulações funcionam como verdadeiros laboratórios virtuais e que podem ser de grande valia em sala de aula, principalmente nas escolas que não possuem laboratórios adequados para aulas as práticas.

As simulações computacionais possibilitam aos alunos observar em alguns minutos a evolução temporal de um fenômeno que levaria horas, dias, meses ou anos em tempo real, além de permitir ao estudante repetir a observação sempre que o desejar (TAVARES, 2008).

De acordo com Filho (2010) é imprescindível que os materiais que estão ligados aos recursos didáticos tecnológicos sejam potencialmente significativos, fazendo ligação entre o conhecimento prévio dos alunos e o novo conhecimento apresentado, vislumbrando a consolidação, revisão e diferenciação dos conceitos trabalhados anteriormente.

No mundo tecnológico, os simuladores são softwares funcionando como verdadeiros laboratórios virtuais, sendo de grande valia nas aulas, principalmente nas escolas que não possuem recursos suficientes e 
laboratórios para fornecerem aulas práticas. 0 uso desta ferramenta pelo professor pode contribuir para uma clareza dos conteúdos e tornar as aulas dinâmicas, reforçando e fixando as definições de ótica aprendida em aulas teóricas.

As simulações se caracterizam por proporcionar aos alunos a manipulação de parâmetros físicos envolvidos em diversas situações e fenômenos, possibilitando uma maior interação do estudante com o conceito estudado e motivando no processo de aprendizagem. Diversos simuladores podem ser utilizados no ensino de Física, a exemplo do PhET 51.

\section{METODOLOGIA}

A referente pesquisa caracteriza-se como um relato de experiência da aplicação de uma proposta didática desenvolvida com o uso do simulador PhET simulations, por ser uma plataforma virtual e uma fonte de acesso a variados tipos de simuladores com foco no ensino de Física. 0 projeto é da Universidade do Colorado Boulder que elabora simulações interativas gratuitas de Matemática e Ciências. O PhET é baseado em extensa pesquisa em educação e envolve os alunos através de um ambiente intuitivo em que aprendem através da exploração e da descoberta.

A pesquisa foi aplicada na escola Ademar Veloso Silveira, situada na cidade de Campina Grande - Paraíba, em uma turma do 20 ano do Ensino Médio com 30 alunos, no ano de 2019 do turno da manhã e teve duração de quatro aulas em dias alternados. Na primeira fase da pesquisa foi aplicado um questionário com o intuito de sondar os conhecimentos prévios dos alunos acerca das TIC e sua utilização no espaço educacional. A segunda fase se deu por duas etapas, onde na primeira etapa foi exposto o conteúdo de lei de Snell, refração, reflexão e dispersão da luz, lente convergente e divergente. Na segunda etapa, os alunos foram guiados por meio de um roteiro a utilizarem o simulador e responderam as atividades referentes aos conteúdos propostos anteriormente. A terceira e última fase da pesquisa, foi aplicado um questionário acerca do uso do simulador por parte dos alunos.

\section{RESULTADOS E DISCUSSÃO}

Na primeira fase da pesquisa foi avaliado o conhecimento prévio dos alunos por meio de um questionário prévio sobre o nível de domínio em tecnologia, e sobre o uso das TIC no ambiente escolar. Ao analisarmos as respostas dos alunos $70 \%$ responderam que tinham domínio tecnológico, $27 \%$ razoável e $6 \%$ ruim. Quanto ao uso das TIC no espaço educacional, todos afirmaram que a escola possui e disponibiliza esses recursos, porém em relação ao seu uso por parte dos professores, $53 \%$ responderam que utilizam em suas práticas educacionais, e $47 \%$ afirmaram que não.

Na segunda fase da pesquisa, os alunos demonstraram bastante interesse e motivação na utilização do simulador proposto. Eles foram guiados por um roteiro, em que responderam algumas questões relacionadas a execução do simulador. Durante a atividade foi possível observar o bom domínio da maioria dos alunos durante a realização da pesquisa tanto na parte tecnológica, quanto nos conteúdos de ótica, em que os mesmos conseguiram utilizar a ferramenta sem muita dificuldade.

Ao analisarmos a questão 1, da segunda fase da pesquisa, em que foi perguntado sobre o fenômeno observado ao clicar no botão para emitir o raio do laser, $70 \%$ dos alunos responderam que estava ocorrendo uma refração, desvio na emissão de luz, mudança no índice de refração de acordo com o material utilizado e os raios fótons eram contínuos, ou seja, os alunos conseguiram enxergar de fato e entenderam o fenômeno visto, argumentando o que achavam e fazendo relações com o conteúdo físico. $15 \%$ responderam que observaram raios em direção a água, mudando sua direção, e $15 \%$ responderam que viam que o raio refletido mudava sua direção. Ou seja, esses $30 \%$ responderam o fenômeno visto com outra visão, mas nada fora da compreensão correta do conhecimento físico.

Nesse sentido, Richardson et al. (2008) comenta que a utilização do simulador facilita descrever a complexidade de problemas e hipóteses, bem como analisar a interação entre variáveis, compreender e classificar determinados processos. Pois, foi possível observar que os alunos obtiveram um fácil

51 PhET (Physics Education Technology Project) da Universidade do Colorado (EUA). Este projeto disponibiliza grande quantidade de simuladores virtuais para o uso educativo. Os simuladores são de fácil utilização e após baixados podem ser executados sem conexão com a internet. Em geral os simuladores deste projeto exploram os conteúdos físicos com riqueza de detalhes e com boa interatividade, possibilitando ao usuário a alteração dos parâmetros da simulação. 
entendimento do assunto sobre a teoria envolvida e fenômenos complexos que seriam difíceis/complicados de demonstrar na vida real, analisando com várias ferramentas (variáveis) que o simulador PhET os proporcionou.

Na questão 2, foi pedido aos alunos, que mudassem a opção de raio para ondas, para observarem o fenômeno e depois voltar para a opção anterior (raio), acrescentando a ferramenta de medição da intensidade dos raios, repetindo a medição com diversos materiais para os meios, conforme Figura 1.

Figura 1: Observando a intensidade dos raios

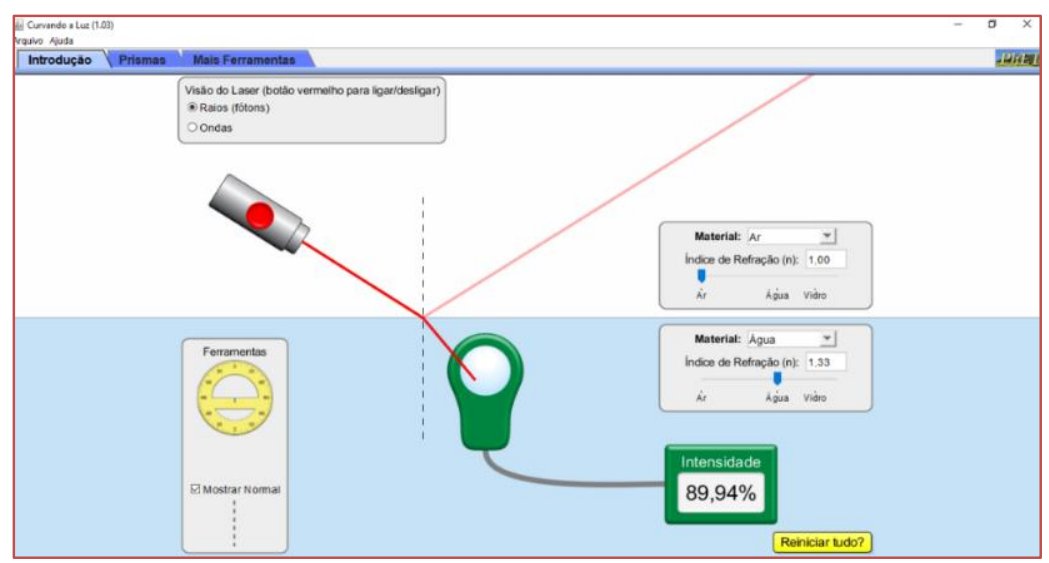

Fonte: Phet simulations

Analisando as respostas dos alunos, 75\% responderam que o fenômeno da refração foi diferente dependendo do material estudado, enfatizando que cada material possui um índice de refração distinto enfatizando um aumento ou diminuição de acordo com a mudança de material. 12\% disseram que dependendo do material, a intensidade dos raios irá sofrer variações e 13\% responderam que interferia, mas que não há refração e sim uma reflexão, enfatizando que a luz não segue em linha reta e sim que desviava. Logo, a maioria dos alunos conseguiram chegar na resposta coerente do que se pedia.

Conforme Medeiros e Medeiros (2002) a utilização de simulações, de fato, contribuíram no processo de ensino e aprendizagem dos alunos que, mesmo não sendo uma opção para solucionar os desafios que eles enfrentam no ensino, proporcionou uma atividade mais dinâmica e interessante, despertando a curiosidade dos alunos e a vontade de aprender mais.

$\mathrm{Na}$ terceira questão, foi solicitado aos alunos a incrementação da ferramenta do transferidor, movimentando o laser para analisar os ângulos e os demais fenômenos observados anteriormente, relatando o que acontecia se alterar os materiais com a movimentação do laser de acordo com o ângulo selecionado, conforme a Figura 2.

Figura 2 - Ângulo entre raios e análise dos materiais

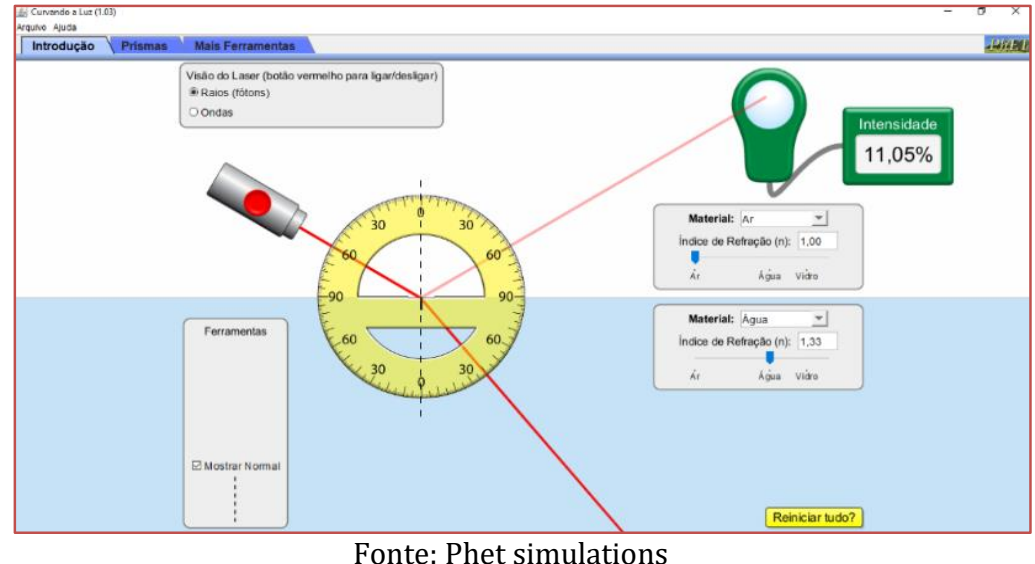


Analisando as respostas dos alunos, $80 \%$ dos alunos responderam que, com a alteração do ângulo, observase uma variação da refração, como consequência o aumento ou diminuição da sua intensidade, argumentando que o fenômeno de reflexão aparece também e que sofre mudanças. 10\% responderam que apenas o ângulo de reflexão e refração sofria variações e 10\% disseram que a reflexão é menor devido a sua intensidade baixa e a refração é maior por causa da sua intensidade que aumenta. Nesse sentido, Ribeiro e Verdeaux (2012) comenta que o estudo de ótica é um dos principais ramos relevantes da Física, no sentido de demonstrar experimentos reais e/ou virtuais e exploração de conceitos a partir de atividades práticas que levam os alunos à reflexão.

No geral, ao analisarmos todas as questões respondidas, todos os alunos conseguiram resolver as questões com o simulador Phet, tendo um resultado significativo e satisfatório, alcançando os objetivos da pesquisa, proporcionando uma compreensão dos conceitos físicos trabalhados na proposta Nesse sentido, Oliveira e Moura (2015) comentam que as TIC quando são utilizadas, melhoraram o processo de ensino, pois criam ambientes virtuais de aprendizagem, colaborando com o aluno na assimilação dos conteúdos e no desenvolvimento do pensamento crítico-criativo e na aprendizagem cooperativa, uma vez que torna possível a realização de atividades interativas.

Na terceira fase de análise da pesquisa, foi aplicado um questionário sobre o uso do simulador. Em uma das perguntas, os alunos foram interrogados se eles acharam que o uso do simulador contribuiu para melhorar o ensino e a aprendizagem dos conteúdos de ótica, em que todos responderam que "sim". Nessa análise, podemos citar a fala de um aluno, em que fez o seguinte comentário: "o uso do simulador facilitou muito o aprendizado, aproximando mais da realidade e associando as teorias estudadas em fenômenos observados por meio de experimentos virtuais" (aluno x). Outro aluno comentou que foi mais prático o uso do software e que auxiliou no entendimento do assunto, deixando a aula mais dinâmica, fazendo com que os alunos interagissem mais. Um terceiro aluno comentou que o simulador como ferramenta proporciona a interação e visualização do conteúdo, tornando o assunto mais interessante.

De modo geral, ao verificar as falas elencadas dos alunos, foi possível observar bons resultados da pesquisa, uma vez que os alunos gostaram da proposta, comentando que a mesma facilitou no entendimento do assunto e ficou mais fácil de associar a teoria com a prática utilizando o simulador.

Diante destas análises, podemos citar Tavares (2008), quando comenta sobre a oportunidade de que os alunos possuem de observar o fenômeno físico que levaria um tempo considerável para compreensão da teoria em sala de aula, nos livros e imagens, além de permitir que os discentes repitam a observação sempre que desejar, despertando mais ainda a sua curiosidade. Nesse contexto, Coelho (2002) também argumenta sobre as vantagens do acesso aos laboratórios experimentais e simuladores, uma vez que, os mesmos, podem proporcionar a clareza no entendimento da teoria envolvida, com o uso dessas ferramentas tecnológicas, como o uso das diversas variáveis que os alunos manusearam no simulador utilizado na proposta desta pesquisa, como as ferramentas de medição da intensidade da velocidade do raio, ângulo de incidência e refração, etc.

\section{CONSIDERAÇÕES FINAIS}

A presença e utilização das TIC nas escolas devem ter como foco promover o acesso às informações, auxiliar na construção de conhecimentos, desenvolver novas habilidades como o uso de diferentes mídias, facilitar o processo de ensino e aprendizagem e propiciar melhor interação entre a comunidade escolar.

Nesse contexto, o uso dos simuladores computacionais no ensino de Física é uma alternativa que pode possibilitar a melhoria do processo de ensino-aprendizagem, uma vez que, por meio das simulações o aluno tem a oportunidade de levantar e desenvolver hipóteses, testá-las, analisar e discutir resultados obtidos, melhorando a aprendizagem dos conteúdos, apresentando-se se como um poderoso recurso didáticopedagógico para atualizar, qualificar e aperfeiçoar o processo didático.

Sabe-se que muitas vezes o estudo da ótica é muitas vezes ministrado de forma expositiva, mecânica e sem importância significativa, com demonstrações das fórmulas e conceitos rápidos, com poucos exemplos e/ou assimilações com o cotidiano. Sendo assim, a realização da pesquisa trouxe meios para a melhoria do processo de ensino e aprendizagem e novas oportunidades para desenvolver aulas mais dinâmicas e interativas, com o uso do simulador Phet.

As TIC apresentam a perspectiva de transformar e melhorar a educação, mas deve-se levar em consideração que ainda existem muitos problemas que estão associados à incorporação dessas tecnologias nas escolas e no processo de ensino-aprendizagem. Os simuladores se bem utilizados, poderão propiciar processos 
educativos mais dinâmicos onde os alunos terão a possibilidade de observar os fenômenos físicos, interagindo com as suas variáveis, sendo construtores do próprio conhecimento.

\section{REFERÊNCIAS}

[1] COSTA, L. G.; BARROS, M. A. O Ensino da Física no Brasil: Problemas e Desafios. 2015.

[2] COELHO, Rafael Otto. O uso da informática no ensino de física de nível médio. Dissertação (Mestrado em Educação) - Faculdade de Educação. Universidade Federal de Pelotas. Pelotas, 2002.

[3] FILHO, Geraldo Felipe de Souza. Simuladores computacionais para o ensino de Física básica: uma discussão sobre produção e uso. Dissertação de Mestrado (Programa de Pós-Graduação em Ensino de Física), Instituto de Física, da Universidade Federal do Rio de Janeiro. Rio de Janeiro, 2010.

[4] KENSKI, V. M. Educação e Tecnologias: o novo ritmo da informação. 3aㅗ ed. Campinas, SP: Papirus, 2007.

[5] MEDEIROS, Alexandre; MEDEIROS, Cleide de Farias. Possibilidades e Limitações das Simulações Computacionais no Ensino da Física. Revista Brasileira de Ensino de Física, v. 24, n.2, 2002.

[6] MORAN, José. As mídias na educação. São Paulo, 2007.

[7] MOURA, Wlademir Cardoso de. Proposta de ensino de Física em óptica geométrica usando uma simulação do PhET e óptica física através de experimentos. 2016. 140 f. Dissertação (Mestrado Profissional em Ensino de Física PROFIS). Instituto Fed. de Educ, Ciên. e Tecn. do Rio Grande do Norte, São Paulo, 2016.

[8] OLIVEIRA, Cláudio de; MOURA, Samuel Pedrosa. Tic's na educação: a utilização das tecnologias da informação e comunicação na aprendizagem do aluno. Periódicos PUC Minas. v.3 n1. 2015. Disponível em: http://periodicos.pucminas.br/index.php/pedagogiacao/article/view/11019/8864. Acesso em: 27 out. 2019.

[9] RIBEIRO, Jair Lucio Prados da Silva, e VERDEAUX, Maria de Fátima da Silva. Atividades experimentais no ensino de óptica: uma revisão. DF, 2012.

[10] RICHARDSON, R. J. et al. Pesquisa social: métodos e técnicas. 3. ed. São Paulo: Atlas, 2008.

[11] SILVA, Marco. Sala de aula interativa: a educação presencial e a distância em sintonia com a era digital e com a cidadania. In: CONGRESSO BRASILEIRO DA COMUNICAÇÃO, 24., 2001, Campo Grande. Anais do XXIV Congresso Brasileiro da Comunicação, Campo Grande: CBC, set. 2001.

[12] TAVARES, R. Animações interativas e mapas conceituais: uma proposta para facilitar a aprendizagem significativa em ciências. Revista online Ciência \& Cognição, v. 13, n. 2, p. 99-108, 2008.

[13] ZARA, R.A. Reflexão sobre a eficácia do uso de um ambiente virtual no ensino de Física. In: II Encontro Nacional de Informática e Educação, Campus Cascavel-PR, 265-272. 2011. 


\section{Capítulo 18}

Cursos Superiores de Tecnologia: Inserção e importância no atual cenário educacional brasileiro

\section{Sylvia Cristina de Azevedo Vitti}

Resumo: Este artigo é resultado de uma revisão de literatura que tomou por base trabalhos de autores cujos estudos têm como foco os Cursos Superiores de Tecnologia e sua expansão no cenário educacional nacional, além de dados disponibilizados pelo MEC e legislação pertinente. 0 estudo tem como objetivo apresentar os Cursos Superiores de Tecnologia como uma modalidade de ensino superior atualmente em evidência. Esta vem favorecer, com o auxílio de políticas públicas educacionais, o acesso de grande parte da população ao ensino superior, além de preconizar os princípios da indissociabilidade entre a formação geral e profissional na perspectiva de uma educação integral e que se adequa às necessidades dos graduandos diante das altas exigências de empregabilidade no Brasil. Nesse contexto, conclui-se que tais cursos, oferecidos por instituições públicas e privadas, desempenham um papel importante como ferramenta oportuna para a expansão do ensino superior brasileiro. Os Cursos Superiores de Tecnologia constituem um tipo de graduação disponível em nosso país, são reconhecidos pelo MEC e possuem Diretrizes Curriculares Nacionais definidas pelo Conselho Nacional de Educação. Eles oferecem uma formação mais breve, focada, competitiva e de qualidade e se adequam muito bem ao atual contexto educacional brasileiro e às crescentes demandas do mercado de trabalho por profissionais com formação sólida em sua área de atuação.

Palavras-chave: Cursos Superiores de Tecnologia; Ensino Superior; Educação profissional. 


\section{INTRODUÇÃO}

A educação é um fator essencial no desenvolvimento dos indivíduos, propiciando a formação de cidadãos plenos, questionadores, autônomos e capazes de atuar positivamente na promoção de mudanças sociais e no crescimento de seu país. Ela influencia grandemente a mobilidade social e econômica, principalmente para aqueles que completam o ensino superior.

0 acesso ao ensino superior no Brasil não é uma realidade presente na vida de todos os brasileiros, embora a busca por esta formação tenha aumentado expressivamente nos últimos anos. Isto pode ser observado pelo crescente número de matrículas nas mais diversas instituições de ensino superior do país, fato que vem ocorrendo desde a década de 1970. A expansão do ensino superior brasileiro deu-se de tal forma, que o acesso a este nível de ensino atingiu um público que até então não havia imaginado a possibilidade de realizá-lo, como, por exemplo, alunos com faixas etárias mais elevadas (SCHWARTZMAN; CHRISTOPHE, 2005). A busca pelo ensino superior segue intensa até o presente momento e faz parte do desejo dos que almejam uma inserção no competitivo mercado de trabalho, constituindo-se, também, em uma necessidade para atender às exigências atuais de empregabilidade.

Nos últimos anos, políticas públicas voltadas para a área da Educação têm favorecido uma expressiva expansão da educação superior brasileira. O Plano Nacional da Educação (PNE), decenal, aprovado pela Lei $13.005 / 2014$ e que estará em vigor até 2024 , e que estará em vigor até 2024 , apresenta metas e estratégias para melhorar e expandir a educação no país em todos os níveis, num esforço conjunto das esferas federal, estadual e municipal. A meta 12 do PNE visa elevar a oferta de vagas no ensino superior e aumentar a taxa de matrículas de jovens na faixa etária de 18 a 24 anos, assegurando-lhes educação de qualidade (BRASIL, 2014). Além disso, de acordo com a Secretaria de Assuntos Estratégicos da Presidência da República e do Instituto de Pesquisa Econômica Aplicada - IPEA, segundo UOL ECONOMIA, 2013, os jovens brasileiros da atualidade são e serão a maior força de trabalho da história do país. A previsão é de que nos próximos dez anos os jovens de 15 a 29 anos chegarão a cerca de 50 milhões de pessoas, representando $26 \%$ da população brasileira, o que remete à importância das políticas públicas atuais direcionadas à qualificação do ensino profissional no Brasil.

Nesse contexto, os Cursos Superiores de Tecnologia (CST), ofertados por instituições públicas e privadas, vêm desempenhando um importante papel e ganhando destaque, uma vez que são uma ferramenta importante no que diz respeito à expansão do ensino superior brasileiro, à qualificação de jovens e sua inserção no mercado de trabalho.

O presente trabalho é fruto de uma revisão bibliográfica baseada em trabalhos de autores cujos estudos têm como foco os CST e sua expansão no Brasil, além de dados disponibilizados pelo MEC e legislação pertinente. O estudo visa apresentar os CST como uma modalidade de ensino superior em evidência e apresenta um panorama da história, evolução e características destes cursos no atual cenário educacional brasileiro. Tendo em vista o acesso crescente ao ensino superior e a crescente evidência e procura pelos CST no contexto nacional, faz-se necessário conduzir estudos que tenham tal temática como foco. Os CST apresentam caráter profissionalizante, mas também podem ser vistos dentro da ótica da formação integral, o que contribui para a formação de cidadãos plenos, críticos e reflexivos.

\section{ASPECTOS HISTÓRICO-POLÍTICOS DA EDUCAÇÃO PROFISSIONAL E TECNOLÓGICA NO BRASIL}

As origens da Educação Profissional no Brasil remontam ao ano de 1909, considerado o ano oficial da sua criação em nosso país, quando o presidente da república Nilo Peçanha criou as primeiras Escolas de Aprendizes Artífices em diferentes unidades federativas do país, destinadas ao ensino profissional, primário e gratuito, visando, inicialmente, dar formação profissional e beneficiar as camadas mais desfavorecidas da sociedade. De acordo com dados oficiais do Portal do MEC, em 2009 foi comemorado o centenário da criação da Educação Profissional no Brasil (BRASIL, 2017).

Desde a sua origem, ao longo das décadas, a Educação Profissional foi passando por transformações e evolução, impulsionada por uma política de criação de novas escolas e novas especializações e constantes mudanças da legislação. Na década de 1940 foram criadas as Escolas Industriais e Técnicas de nível médio. No governo de Juscelino Kubitschek, de 1956 a 1961, foram criadas as Escolas Técnicas Federais em decorrência de um grande desenvolvimento industrial e a preocupação com a formação de profissionais voltados para as metas de desenvolvimento do país. Na década de 1970 foram criados os Centros Federais de Educação Tecnológica - CEFETs e teve início a criação da Rede Federal de Educação Profissional e Tecnológica do país (BRASIL, 2017). 
Na década de 1980 foi elaborada a nova Constituição Federal de 1988, que assegura o direito à educação e formação a todos os cidadãos em termos de igualdade. Na década seguinte, o governo de Fernando Henrique Cardoso (1995-2030), marcado por ideologia neoliberal, trouxe novas tendências para a política de educação profissional do país, considerando como urgente a necessidade de formação de trabalhadores capazes de se adaptarem às inovações tecnológicas do mercado de trabalho, em sintonia com agências internacionais, como o Banco Interamericano do Desenvolvimento (BID) e o Banco Internacional para Reconstrução e Desenvolvimento (BIRD), sendo a Educação Profissional concebida como uma das estratégias para resolver o problema da qualificação da mão de obra brasileira (RAMOS, 2014). De acordo com Ramos (2014), nesse período a Educação Profissional foi impulsionada pelo Plano Nacional de Formação Profissional - PLANFOR, do Ministério do Trabalho, em 1995. Nessa época também ocorreu a expansão da iniciativa privada na área da educação, com a adesão da sociedade civil ao Programa de Expansão da Educação Profissional - PROEP, do MEC, e os dados do Censo de 2003 demonstram, então, que a oferta de Educação Profissional pelo setor privado superou a oferta pública (RAMOS, 2014).

Em 1996 foi criada a nova Lei de Diretrizes e Bases da Educação (LDB), Lei no 9.394/96, que é considerada o marco legal na história e evolução da Educação Profissional e Tecnológica, por dispor sobre ela num capítulo próprio, concedendo-lhe destaque em seus artigos 39 a 42, estabelecendo os seus princípios norteadores, instituindo os CST no Brasil e a verticalização dessa modalidade de educação, tratando esses cursos de forma adequada, apropriada, moderna e inovadora (BRASIL, 1996).

De acordo com o Parecer CNE/CP 29/2002, que dispõe sobre a Educação Tecnológica na Legislação Educacional atual, "A Educação Profissional não é mais concebida como um simples instrumento de política assistencialista ou linear de ajustamento às demandas do mercado". Ela é agora concebida como importante estratégia para os cidadãos terem acesso às conquistas científicas e tecnológicas da sociedade, visando, além da formação técnica específica, a compreensão global do processo produtivo, numa abordagem integral (BRASIL, 2002, p.14).

Segundo Rosetti Jr. e Schimiguel (2011), conforme a LDB/1996, atualmente no Brasil, a expressão educação tecnológica tem um sentido legal preciso, que é a formação de nível superior de curta duração voltada para a capacitação para as profissões, sobretudo na área industrial, enquanto a educação técnica refere-se à formação de nível médio. Portanto, os CST não podem ser confundidos com os cursos de nível médio e sequenciais. Rosetti Jr. e Schimiguel (2011) afirmam que esses cursos não são novidade em nosso país, uma vez que centenas deles já são reconhecidos nacionalmente e já formaram inúmeros profissionais. Da mesma forma, os autores mencionam que novos cursos de educação superior tecnológica têm sido implantados em instituições públicas e privadas brasileiras e que registros históricos apontam que os tecnólogos brasileiros já atuam no Brasil há aproximadamente cinquenta anos. Esta modalidade de graduação teve sua origem e composição na estrutura da educação profissional brasileira e a implantação destes cursos já constava na Lei Federal 5.540/1968, conhecida como lei da reforma universitária, que abria a possibilidade de criação de cursos profissionais de curta duração, habilitações intermediárias de grau superior. De acordo com os autores, os objetivos definidos para a Educação Tecnológica por esta lei visam [...] "atender aos diversos setores da economia, abrangendo áreas especializadas” (ROSETTI JR.; SCHIMIGUEL, 2011, p. 06). Os autores esclarecem que os objetivos são iguais aos definidos pela LDB/1996 para a Educação Superior, no que tange a "formar diplomados nas diferentes áreas de conhecimentos, aptos para a inserção em setores profissionais".

Na segunda metade do mandato do presidente Luiz Inácio Lula da Silva (2003 - 2010), houve um grande impulso dado à Educação Profissional no país, em seus vários níveis, em defesa de uma organização sistêmica da educação profissional, com definição de financiamento específico, com integração curricular do ensino médio e técnico, conforme prevê o parágrafo 2º do artigo 36 da LDB/1996, e monitoramento e garantia da qualidade, com controle social, do nível tecnológico da educação profissional (RAMOS, 2014). Nessa época, em 2008, foram criados os Institutos Federais de Educação, Ciência e Tecnologia, instituições públicas dentro do Plano de Expansão da Rede Federal de Educação Profissional e Tecnológica, que, dentre outros aspectos, ficou marcado pela determinação do presidente Lula em assegurar à educação tecnológica um lugar privilegiado nas políticas do seu governo, por considerá-la de grande importância para um desenvolvimento nacional soberano, sustentável e inclusivo. Pacheco, Pereira e Sobrinho (2010) em artigo sobre a criação desses institutos, ressaltam a nova face da Educação Profissional e Tecnológica brasileira. De acordo com os autores, a SETEC/MEC vem, desde então, empenhando-se em oferecer oportunidades de escolarização e profissionalização a milhares de jovens brasileiros, a partir de 18 anos, que se encontram à margem da sociedade, seja no que tange à escolarização seja na perspectiva de sua inserção no mercado de trabalho. Segundo os autores, as ações da SETEC/MEC procuram pautar-se pela indissociabilidade entre formação geral e profissional na perspectiva de uma educação integral. 
Atualmente, os CST acham-se em evidência, pois na última década houve um aumento significativo na oferta de educação superior em decorrência de políticas governamentais de expansão e democratização do ensino superior. Muitos centros universitários, faculdades, universidades, centros de educação tecnológica, faculdades de tecnologia, escolas e instituições superiores passaram a oferecer novas modalidades e novos cursos, frutos de alterações da legislação educacional e, também, dos novos contornos sociais e econômicos do país. Também concorreram para isso as políticas públicas educacionais do governo federal que, visando a democratização e a expansão do ensino superior entre a população brasileira, criou os programas que visam incentivar e apoiar o acesso e permanência de jovens estudantes nos estudos superiores, tanto em instituições públicas da rede federal como na rede privada.

A revisão da literatura revela que em meados do século XX havia uma desvalorização dos cursos profissionalizantes em relação aos de bacharelado e licenciatura, por estarem associados à história da educação profissional no Brasil, originalmente destinada às classes desfavorecidas e desprivilegiadas da sociedade, o que resultou numa "dualidade" no seio da educação brasileira (DETREGIACHI Fo., 2012; RAMOS, 2014). Entretanto, as políticas educacionais das últimas décadas e pós LDB/1996 ressaltam o valor e a importância da educação profissional para o desenvolvimento do país e a sua inserção na área tecnológica, para a formação de nível superior e qualificação de jovens, assim como para a melhora dos níveis de empregabilidade e renda da população, contribuindo para a superação dessa dualidade e preconceito (RAMOS, 2014; MARIN et al., 2019).

\section{0 ENSINO SUPERIOR BRASILEIRO NUMA SOCIEDADE EM TRANSFORMAÇÃO}

Estamos vivendo em uma sociedade em constante transformação e rápidas mudanças vêm ocorrendo no ensino superior brasileiro nas últimas décadas em decorrência das novas demandas do mercado de trabalho nacional e internacional e, também, da globalização. As rápidas transformações sociais e tecnológicas têm afetado profundamente o ser humano, o meio ambiente e as instituições e organizações, principalmente as produtivas, com a adoção das novas tecnologias, que impactam hábitos, valores e tradições já consolidados (JUCÁ; OLIVEIRA; SOUZA, 2010). Consequentemente, a graduação universitária tem sofrido alterações devido a estas novas demandas. Atualmente, o que se observa são exigências cada vez mais sofisticadas por parte das empresas, que procuram profissionais com competências afinadas e foco em suas áreas de atuação Como consequência, os CST estão sendo oferecidos como resposta a essas demandas; são estruturados de forma mais direcionada a essa nova realidade e oferecidos num período mais breve do que os de bacharelado e licenciatura. Eles são uma grande oportunidade para a formação superior num prazo mais curto e a um custo menor, com um grande apelo junto aos jovens, fazendo com que sua procura e oferta venham crescendo rapidamente nos últimos anos, atraindo cada vez mais o interesse dos jovens brasileiros interessados em qualificação e formação profissional, que atendam às demandas das empresas e o mercado de trabalho (ROSETTI JR.; SCHIMIGUEL, 2011). Deste modo, esses cursos vêm conquistando espaço em um cenário antes dominado por bacharelados e licenciaturas, conforme dados dos Censos de Educação Superior de 2016, 2017 e 2018.

De acordo com a Revista G1 - Educação, 2018, a procura por CST dobrou no período de 2007 a 2017, registrando um aumento de 119,4\%. Segundo o Censo de Educação Superior/2018, 58\% dos alunos ingressam em cursos de bacharelado, 20,9\% nos CST e 20,5\% ingressam em cursos de licenciatura (BRASIL, 2018; 2019). Outro dado interessante apresentado pela revista anteriormente citada foi que o número de alunos que concluem a graduação tecnológica também dobrou entre 2007 e 2017, indo de 84.341 em 2007 para 196.999 em 2017, sendo que as matrículas aumentaram em 140\%. Em 2018, das inscrições para os cursos superiores de tecnologia efetuadas pelo Sistema de Seleção Unificada (SiSU), a maioria concentrouse nos cursos de Análise e Desenvolvimento de Sistemas, Gestão Pública, Alimentos, Gestão Ambiental, Gestão de Turismo, Radiologia, Logística, Redes de computadores, Automação Industrial e Sistemas para Internet, segundo a Revista G1 - Educação, 2018.

De acordo com informações do Ministério da Educação (MEC), que constam do Portal da Rede Federal de Educação Científica e Tecnológica, os CST são oferecidos em instituições de ensino públicas integrantes da Rede Federal de Educação Profissional e Tecnológica, como os Centros Federais de Educação Tecnológica (CEFETs), os Institutos Federais de Educação, Ciência e Tecnologia (IFs) e em universidades ou faculdades públicas e privadas, que oferecem Educação Profissional e Tecnológica (BRASIL, 2009). 
Segundo Rosetti Jr. e Schimiguel (2011), a rede de ensino superior privada é mais afinada às novas necessidades e atuais demandas do mercado de trabalho, sendo que estas instituições vêm liderando a oferta de novos cursos de formação de tecnólogos, com oferta abundante e diversificada. 0 número de matrículas na rede privada nos últimos 10 anos (485.623 matrículas) foi bem superior ao da rede pública (98.884 matrículas), sendo que quase a metade destas matrículas ocorreram em cursos à distância, conforme dados da Revista G1 -Educação, 2018.

\section{CONSIDERAÇÕES SOBRE A EDUCAÇÃO SUPERIOR TECNOLÓGICA}

Atualmente no Brasil existem três tipos de cursos superiores: bacharelado, licenciatura e tecnológico. Os cursos de bacharelado e licenciatura requerem de quatro a seis anos, em média, para serem concluídos, enquanto os CST podem ser concluídos em dois ou três anos, dependendo do curso. Todas essas modalidades de cursos superiores são graduações reconhecidas pelo MEC, permitindo ao aluno concluinte cursar todo tipo de pós-graduação. Entretanto, foi com a LDB/1996 que houve um grande avanço no contexto dos Cursos Superiores de Tecnologia, uma vez que tais cursos foram inseridos de forma horizontal aos de bacharelado e licenciatura, passando a ser vistos em pé de igualdade com as demais modalidades de educação superior, deixando de lado o estigma de curso superior de curta duração, favorecendo e estimulando o trabalhador, jovem ou adulto, a se qualificar e progredir em sua formação profissional como tecnólogo (BRASIL, 1996), cuja profissão vem sendo cada vez mais reconhecida e valorizada.

Para Leite Lima:

Os Cursos Superiores de Tecnologia são legalmente cursos regulares de graduação, com Diretrizes Curriculares Nacionais definidas pelo CNE, focados no domínio e na aplicação de conhecimentos científicos e tecnológicos em áreas de conhecimento relacionado a uma ou mais áreas profissionais. Permitem todo tipo de pós-graduação. Buscam o desenvolvimento de competências profissionais que possibilitem a correta utilização da tecnologia. 0 acesso ao curso de tecnologia ocorre como nos outros cursos de graduação: é aberto a candidatos que tenham concluíd o o ensino médio e tenham sido classificados em processo seletivo (LEITE LIMA, 2002, apud SCHWARTZMAN; CHRISTOPHE, 2005, p. 88).

De acordo com a Legislação Básica da Educação Profissional e Tecnológica de nível superior, elaborada pelo MEC, os Cursos Superiores de Tecnologia:

Têm por finalidade o desenvolvimento de competências profissionais que permitam tanto a correta utilização e aplicação da tecnologia e o desenvolvimento de novas aplicações ou adaptação em novas situações profissionais, quanto o entendimento das implicações daí decorrentes e de suas relações com o processo produtivo, a pessoa humana e a sociedade. 0 objetivo a ser perseguido é o do desenvolvimento de qualificações capazes de permitir ao egresso a gestão de processos de produção de bens e serviços resultantes da utilização de tecnologias e o desenvolvimento de aptidões para a pesquisa tecnológica e para a disseminação de conhecimentos tecnológicos (BRASIL, MEC, Parecer CNE/CP n 29/2002, p.271).

Segundo Schwartzman e Christophe (2005), a Educação Tecnológica em nosso país é a formação superior de menor duração e voltada à capacitação para diversas profissões, principalmente na área industrial, sendo mais orientada para o mercado de trabalho.

Atualmente a oferta dos CST é grande, abundante e diversificada e a procura por eles está em ascensão. No ano de 2006, através do Decreto 5.773/2.006, foi elaborado pelo MEC o primeiro Catálogo Nacional de Cursos Superiores de Tecnologia, que apresentou 98 denominações de cursos. Uma segunda versão foi disponibilizada em 2010, apresentando 113 cursos. 0 catálogo é atualizado periodicamente e em sua terceira e última edição, com a publicação da Portaria MEC no 413, de 11 de maio de 2016, apresenta 134 denominações de cursos superiores, divididos em 13 eixos tecnológicos, que estruturam sua organização (BRASIL, 2016). 
O advento da globalização e internacionalização do mercado de trabalho brasileiro, resultaram em um aumento das exigências por escolaridade e formação superior e a graduação superior tecnológica está sendo considerada como uma oportuna solução acadêmica para essa demanda; ela vem atender a essa necessidade de formação superior requerida pelo atual sistema produtivo brasileiro, com agilidade, especificidade e competência. Os CST têm demonstrado uma significativa capacidade de adequação ao novo contexto do ensino superior brasileiro e, por serem ofertados num período de tempo mais curto do que os tradicionais, tornam possível para uma enorme parcela da população brasileira a formação superior com menor custo e grande afinidade às necessidades das organizações empresariais no Brasil (JUCÁ; OLIVEIRA; SOUZA, 2010; ROSETTI JR.; SCHIMIGUEL, 2011).

A revisão da literatura pertinente mostra a preocupação do governo e do MEC em revitalizar, fortalecer e consolidar uma cultura de formação profissional no Brasil, e que a estratégia governamental de fomentar a Educação Profissional e os Cursos Superiores Tecnológicos não consiste em uma novidade quanto à criação de uma nova modalidade, mas a reorganização, reformulação e expansão desses cursos.

\section{CONTRIBUIÇõES DA EDUCAÇÃO SUPERIOR TECNOLÓGICA PARA A EXPANSÃO DA EDUCAÇÃo SUPERIOR NO BRASIL}

O avanço da Educação Superior Tecnológica deu-se a princípio na esfera federal, através dos Institutos Federais de Ensino Superior. Posteriormente, o crescimento foi observado não somente na esfera pública, mas também na privada, sendo esta modalidade de ensino superior uma importante ferramenta para a expansão das instituições privadas.

Os CST têm sido ofertados pelas instituições particulares de ensino superior por motivos diversos, que representam grandes atrativos para os estudantes. Dentre estes estão a duração mais enxuta destes cursos, o que favorece uma menor taxa de evasão, o foco em determinadas carreiras, mensalidades mais acessíveis e o desenvolvimento de cursos de acordo com as áreas de maior demanda e, também, regionais do país (COSTA et al., 2012). Eles representam um grande avanço no que diz respeito à expansão do ensino superior brasileiro; são cursos regulares de graduação, com Diretrizes Curriculares definidas pelo Conselho Nacional de Educação e focados no domínio de conhecimentos científicos e tecnológicos relacionados a áreas profissionais específicas. Atualmente, os currículos desses cursos apresentam grande aderência à nova realidade do ensino superior e às demandas do mercado de trabalho, uma vez que são cada vez maiores as exigências por escolaridade e pela formação superior.

Segundo Marin et al. (2019), o aumento de matrículas nos CST nos últimos anos, tanto nas modalidades presencial como a distância (EaD), sinalizam que "[...] estão sendo realizados investimentos na educação profissional e tecnológica de nível superior, principalmente pela inciativa privada, mas também apoiada pela expansão dos IFES - Institutos Federais de Ensino Superior" (BRASIL, 2002, apud MARIN et al. 2019, p. 127). Os autores apontam que a nova estrutura social e política atual do país, os novos modelos de produção industrial combinados com as crescentes inovações tecnológicas passam a requerer dos trabalhadores uma escolaridade adequada e contínua qualificação profissional. Isto requer um novo tipo de profissional, que passa a ser exigido pelo mercado: o tecnólogo (MARIN et al., 2019).

\section{CONSIDERAÇÕES FINAIS}

Os CST vêm apresentando um expressivo crescimento no cenário educacional brasileiro, conquistando espaço em um contexto antes dominado pelos cursos de bacharelado e licenciaturas, contribuindo para a expansão e acesso ao ensino superior, ao mesmo tempo que oferecem oportunidades de qualificação e formação de profissionais sintonizados com as transformações sociais e tecnológicas da atualidade. Eles proporcionam grande interação com as empresas e os profissionais formados são inseridos mais rapidamente no mercado de trabalho devido a seus currículos especializados e operacionalizados dentro da prática profissional. Desta forma, tornam-se uma ótima oportunidade para aqueles que desejam uma formação superior mais breve ou até mesmo uma reprofissionalização, sem abrir mão de uma formação sólida (JUCÁ; OLIVEIRA; SOUZA, 2010).

Nas instituições privadas de ensino superior, o crescimento da educação superior tecnológica tem sido uma constante pelas vantagens que oferece em termos de menor duração dos cursos e sua orientação mais focada nas necessidades do país. 
Conforme Rosetti Jr. e Schimiguel (2011), a internacionalização do mercado de trabalho nacional aumentou a exigência pela formação superior, sendo que a graduação tecnológica vem ao encontro desta demanda e os CST adequam-se à formação requerida pelo sistema produtivo brasileiro, com agilidade e competência.

Os tecnólogos representam e representarão um grande conjunto de profissionais e novos graduados, em grande sintonia com necessidades específicas do mundo do trabalho. São profissionais que vêm sendo cada vez mais valorizados no competitivo ambiente empresarial, onde competência e habilidades particulares fazem-se necessárias.

\section{REFERÊNCIAS}

[1] BRASIL. Senado Federal. Lei de Diretrizes e Bases da Educação Nacional n. 9.394/96. Brasília, 1996. Disponível em: https://www2.senado.leg.br/bdsf/bitstream/handle/id/70320/65.pdf. Acesso em: 18 abr. 2020.

[2] BRASIL. Ministério da Educação. Secretaria de Educação Profissional e Tecnológica. Diretrizes Curriculares Nacionais no Nível de Tecnólogo. Legislação Básica - Nível Superior. Parecer, CNE/CP no 29/2002. Brasília 2008. 7ạ ed. Disponível em: http://portal.mec.gov.br/setec/arquivos/pdf_legislacao/superior/legisla_superior_parecer292002.pdf. Acesso em: 27 ago. 2020.

[3] BRASIL. Ministério da Educação. Plano Nacional da Educação. 2014. (Lei no 13.005/2014). Disponível em: http://pne.mec.gov.br/18-planos-subnacionais-de-educacao/543-plano-nacional-de-educacao-lei-n-13-005-2014. Acesso em: 28 ago. 2020.

[4] BRASIL. Ministério da Educação. Catálogo Nacional dos Cursos Superiores de Tecnologia, 2016. Disponível em: $\quad$ http://portal.mec.gov.br/index.php?option=com_docman\&view=download\&alias=98211-cncst-2016a\&category_slug=outubro-2018-pdf-1\&Itemid=30192. Acesso em: 27 ago. 2020.

[5] BRASIL. Ministério da Educação. Censo da Educação Superior 2016 - Notas Estatísticas 2016. Disponível em: http://download.inep.gov.br/educacao_superior/censo_superior/documentos/2016/notas_sobre_o_censo_da_educac ao_superior_2016.pdf. Acesso em: 10 jul. 2020.

[6] BRASIL. Ministério da Educação. Censo da Educação Superior 2017 - Notas Estatísticas 2017. Disponível em: http://download.inep.gov.br/educacao_superior/censo_superior/documentos/2018/censo_da_educacao_superior_20 17-notas_estatisticas2.pdf. Acesso em: 26 ago. 2020.

[7] BRASIL. Ministério da Educação. Portal da Rede Federal de Educação Profissional, Científica e Tecnológica. 2017. Disponível em: http://redefederal.mec.gov.br/links/1085-secretaria-de-educacao-profissional-diz-que-mecquer-atrair-os-jovens-para-o-ensino-tecnologico. Acesso em: 14 ago. 2020.

[8] BRASIL. Ministério da Educação. Censo da Educação Superior 2018 - Notas Estatísticas 2018. Disponível em: http://download.inep.gov.br/educacao_superior/censo_superior/documentos/2019/censo_da_educacao_superior_20 18-notas_estatisticas.pdf. Acesso em: 27 ago. 2020.

[9] COSTA, D. M.; PAIVA, R. V. C.; FERREIA, J. C. P.; BARBOSA, F. D. Educação Superior Tecnológica: benefícios e perspectivas. Pretexto, Belo Horizonte, v.13, n.4, p.66-83, out./dez., 2012. Disponível em: http://www.fumec.br/revistas/pretexto/article/view/49. Acesso em: 27 ago. 2020.

[10] DETREGIACHI Fo., E. A evasão escolar na educação tecnológica: estudo de uma Unidade do Centro Estadual de Educação Tecnológica Paula Souza. 2012. 126f. Tese (Doutorado em Educação) - Universidade Estadual Júlio de Mesquita Fo. Faculdade de Filosofia, Ciências e Letras. Marília, SP, 2012.

[11] JOVENS SÃO A MAIOR FORÇA DE TRABALHO DO PAÍS, DIZ ESTUDO. UOL ECONOMIA. Empregos e Carreiras. 2013. Disponível em: https://economia.uol.com.br/empregos-e-carreiras/noticias/redacao/2013/07/22/jovens-saoa-maior-forca-de-trabalho-do-pais-diz-estudo.htm. Acesso em: 30 jul. 2020.

[12] JUCÁ, M. C.; OLIVEIRA, P. J.; SOUZA, R. J. Cursos superiores tecnológicos: um avanço da educação superior no Brasil. In: X Coloquio Internacional sobre Gestión Universitaria em América del Sur. 2010. Disponível em: https://repositorio.ufsc.br/bitstream/handle/123456789/97065/CURSOS\%20SUPERIORES\%20TECNOL\%c3\%93GI COS\%20UM\%20AVAN\%c3\%870\%20DA\%20EDUCA\%c3\%87\%c3\%830\%20SUPERIO.pdf? sequence=1\&isAllowed=y. Acesso em: 09 jul. 2020.

[13] MARIN, A.C.; JUNGER, A.P.; ASSAYAG, R.M.; AMARAL, L.H. Cursos Superiores Tecnológicos no Brasil: o crescimento da modalidade de ensino superior nos últimos anos. Revista Humanidades \& Inovação, Palmas - TO, v.6, n. 2, p. 120-135, fev. 2019. Disponível em: file:///C:/Users/Particular/Downloads/962-Texto\%20do\%20artigo-4106-110-20190307.pdf. Acesso em: 28 ago. 2020.

[14] PROCURA POR CURSO DE ENSINO SUPERIOR NA MODALIDADE “TECNOLÓGICA” DOBRA EM 10 ANOS. G1 EDUCAÇÃ̃. Guia de Carreiras. 2018. Disponível em: https://g1.globo.com/educacao/guia-de- 
carreiras/noticia/2018/12/12/procura-por-curso-de-ensino-superior-na-modalidade-tecnologica-dobra-em-10anos.ghtml. Acesso em: 10 jul. 2020.

[15] RAMOS, M. N. História e Política da Educação Profissional. Coleção Formação Pedagógica, vol. V, 1aㅡ ed. Curitiba: Instituto Federal do Paraná, 2014. 121p. Disponível em: https://curitiba.ifpr.edu.br/wpcontent/uploads/2016/05/Hist\%C3\%B3ria-e-pol\%C3\%ADtica-da-educa\%C3\%A7\%C3\%A3o-profissional.pdf. Acesso em: 18 mar. 2020.

[16] ROSETTI JUNIOR, H.; SCHIMIGUEL, J. Histórico e Contexto Econômico dos Cursos Superiores de Tecnologia no Brasil. Observatório de la Economia Latino-americana. no 152, 2011. Disponível em: http://www.eumed.net/cursecon/ecolat/br/11. Acesso em: 25 jan. 2020.

[17] SCHWARTZMAN, S.; CHRISTOPHE, M. A Sociedade do Conhecimento e a Educação Tecnológica. SENAI, Série Estudos Educacionais, Brasília: 2005. 61p. 


\section{Capítulo 19}

Ensino de engenharia na modalidade remota: A adaptação da disciplina de Saneamento Básico e Ambiental I

\section{Paula Nobre de Andrade}

Maria Bernadette Frota Amora Silva

Resumo: As novas diretrizes curriculares para o ensino de engenharia introduziram mudanças necessárias no sistema de ensino e aprendizagem dessa área. 0 isolamento social ocasionado pela pandemia da COVID-19 forçou a adaptação da educação a novas metodologias de forma abrupta e inesperada. 0 objetivo desse trabalho foi relatar como funcionou a experiência da transição da modalidade de ensino, que passou de presencial para ensino remoto, na disciplina de Saneamento Básico e Ambiental I do Curso de Engenharia Civil do Centro Universitário Christus (UNICHRISTUS). A disciplina foi ministrada no mesmo horário da modalidade presencial com o uso de ferramentas digitais como Google Meet e Moodle. Constatou-se que o resultado do desenvolvimento da disciplina foi satisfatório, pois foi cumprido $100 \%$ da ementa e obteve-se a aprovação de $96 \%$ dos alunos.

Palavras-chave: Ensino Remoto. Ensino por competências. Moodle.

Uma versão inicial desse artigo foi publicada no XLVIII Congresso Brasileiro de Educação em EngenhariaCOBENGE 2020. 


\section{INTRODUÇÃO}

O ensino de engenharia no Brasil passou por mudanças desde a publicação das novas Diretrizes Curriculares Nacionais do Ministério da Educação, de acordo com a Resolução № 2, de 24 de Abril de 2019. 0 Art. 5o da referida resolução, em seus incisos I, II e III, esclarece que existem três tipos de profissionais de engenharia: o engenheiro empreendedor (aquele com perfil de empresário, que tem foco no mercado, em atuar de forma autônoma ou prestando serviços para empreendimentos de maior porte), o engenheiro inovador (centrado na produção e no desenvolvimento técnico) e o engenheiro professor/pesquisador (dedicado a pesquisa acadêmica).

Com as novas diretrizes estabelecidas, o ensino de engenharia deve ser conduzido de tal forma que resulte em uma formação por competências, na qual é necessário que sejam oferecidas ao estudante ferramentas e possibilidades para que possa atuar e/ou escolher quaisquer uma dessas vertentes. Para tanto, é necessário que o aluno sinta que está em um curso de engenharia desde o início, seja pela aplicação prática das ciências básicas ou através de outras ferramentas computacionais (Art. 9o $§ 1$ o da Resolução oㅡ 2 de 24 de abril de 2019).

Segundo Zabala (2010), existem três níveis de transformação do ensino com foco no desenvolvimento de competências: a conversão dos conteúdos tradicionais para o uso desses conteúdos sob a lógica das competências, onde o objetivo é que o aluno saiba aplicar os conhecimentos de cálculo e física em resoluções de situações ou em problemas reais (nível 1), a perspectiva da formação profissional por competências, onde os conteúdos acadêmicos convencionais não são suficientes, pois não incluem muitas das habilidades gerais das profissões (nível 2) e a formação integral dos alunos por um ensino orientado por competências, onde além de saber fazer e saber ser, o aluno deve ser ensinado a saber conviver (nível 3).

A transição da lógica do conteúdo para a lógica do uso efetivo do conhecimento é marcada pela introdução do termo competência no ensino que mobiliza habilidades e atitudes e aproxima a formação do contexto profissional. As competências transversais refletem as habilidades e atitudes que os profissionais devem demonstrar em variados contextos de trabalho, associadas às competências técnicas específicas (MORENO, 2006).

A aprendizagem por competências se converge com a aplicação de desafios, pois, assim, estimula-se a reflexão e a ação. Além do mais, esses resultados vão além de uma simples estatística entre aprovado ou não aprovado, se bem analisados podem preencher lacunas ou deficiências no aprendizado e isso vira base de alimentação do processo construtivo dos objetivos da aprendizagem. Daí a importância de entender a avaliação como etapa e não como objetivo final do processo ensino-aprendizagem (FERRAZ et al.,2019).

Nesse novo panorama, são permitidas atividades com modalidade a distância com carga horária máxima de $40 \%$ da carga horária total do curso podendo ser aplicada a disciplinas inteiras ou parte de disciplinas (Art. 2 o da Portaria no 2.117 de 06 de dezembro de 2019), desde que as mesmas possuam, obrigatoriamente: um tutor que seja engenheiro educador (Parágrafo único da Portaria no 1.134 de 10 de outubro de 2016), alguns

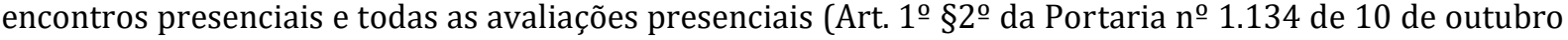
de 2016).

Para as atividades em modalidade a distância, devem-se aplicar métodos e práticas que incorporem o uso integrado de tecnologias de informação e comunicação - atividades mediadas pela tecnologia, por exemplo, a plataforma MOODLE (Art. 2oda Portaria no 1.134 de 10 de outubro de 2016), material didático específico bem como para a mediação de docentes, tutores e profissionais da educação com formação e qualificação em nível compatível com o previsto no Projeto Pedagógico do Curso (PPC) e no plano de ensino da disciplina (Art. $4^{\circ}$ da Portaria no 2.117 de 06 de dezembro de 2019).

Além das novas diretrizes curriculares, a educação tradicional de ensino superior sofreu uma transformação significativa em decorrência da pandemia da COVID-19, doença infecciosa causada por um coronavírus recém-descoberto que possui alta transmissibilidade. Para se controlar a proliferação descontrolada do vírus, que já vitimou mais de 90 mil pessoas no Brasil (BRASIL, 2020), a Organização Mundial de Saúde (OMS) recomendou adotar-se como medida efetiva o isolamento social, que resultou no fechamento total de escolas e universidades, além de outros setores, impedindo que o ensino fosse continuado em seu formato presencial (WHO, 2020a).

Com base no que foi supracitado, este trabalho teve como objetivo relatar como funcionou a experiência da transição abrupta da modalidade de ensino, que passou de presencial para ensino remoto, na disciplina de Saneamento Básico e Ambiental I do Curso de Engenharia Civil do Centro Universitário Christus (UNICHRISTUS), instituição de ensino privada situada no município e Fortaleza, Ceará. 
Além disso, foram avaliados os resultados obtidos pelos discentes da turma no semestre de 2020.1, que abrangeu o período inicial do isolamento social.

\section{IMPLANTAÇÃO DO ENSINO REMOTO}

Com início em 29 de Janeiro de 2020, quando a situação epidêmica grave da COVID-19 concentrava-se na China e em alguns países da Europa (WHO, 2020b), as atividades acadêmicas do semestre 2020.1 ocorreram de forma presencial de acordo com a previsão do calendário acadêmico oficial da UNICHRISTUS. Na instituição, o semestre é divido em três etapas e, ao final de cada uma delas, são feitas as avaliações para compor as notas parciais.

Com o decreto № 33.510 de 16 de março de 2020 do Governo do Estado do Ceará, que decretou situação de emergência em saúde e dispôs sobre medidas para enfrentamento e contenção da infecção humana pelo novo Coronavírus, recomendou-se ao setor privado a suspensão das atividades educacionais presenciais em todas as universidades, faculdades e escolas a partir de 19 de março (Art. 3ㅇ $4^{\circ}$ o do Decreto №33.510 de 16 de março de 2020). Portanto, após a aplicação das avaliações referentes ao primeiro período do semestre letivo, as atividades passaram a ser ministradas de forma integralmente remota.

\section{METODOLOGIAS E RECURSOS UTILIZADOS}

As atividades letivas passaram a ocorrer de forma remota através da integração do Google Meet, que é o serviço de comunicação por vídeo da Google, com a plataforma Modular Object Oriented Distance Learning (Moodle), que é um modelo em software livre, utilizado como ferramenta de apoio ao ensino e à aprendizagem.

O Moodle é um ambiente virtual de aprendizagem que funciona como uma sala de aula online e concentra, num único espaço, todas as informações relativas à disciplina (Figura 1).

Figura 1 - Interface do Moodle da docente.

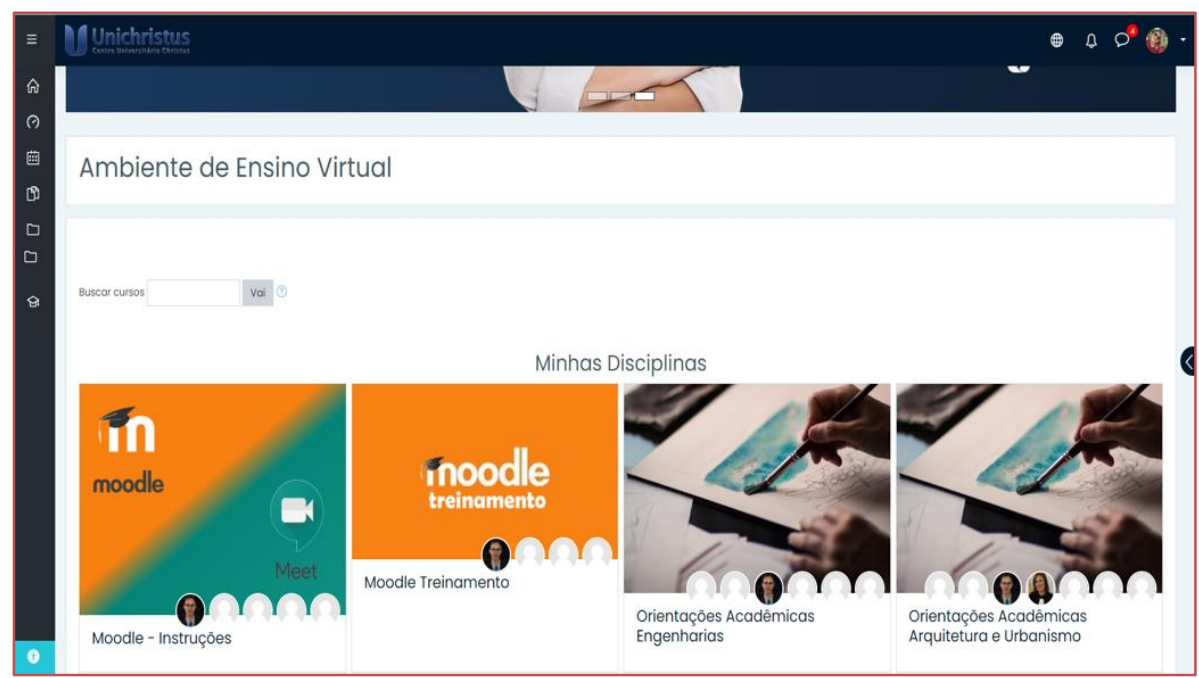

Fonte: Elaborado pelas Autoras (2020).

Dentro do ambiente virtual da disciplina, foi disponibilizado pe///la docente, a cada aula, o assunto que seria abordado com um breve resumo, juntamente com material complementar para estudo, notas de aula, chat para registro de frequência, endereço da videoconferência no Google Meet e vídeo de registro da aula (Figura 2). 
Figura 2 - Ambiente da sala de aula virtual.

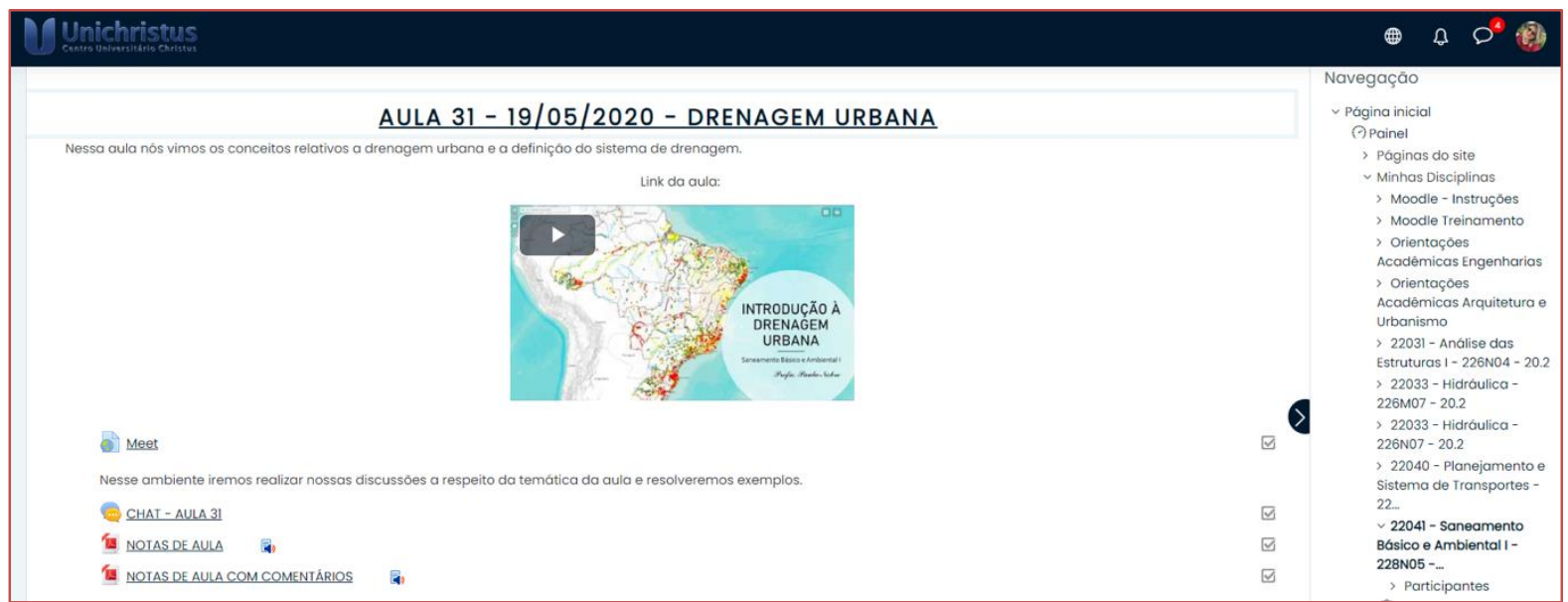

Fonte: Elaborado pelas Autoras (2020).

As aulas foram ministradas de forma remota obedecendo ao mesmo horário vigente desde o início do semestre, de acordo com a decisão institucional de não modificar a grade de horários dos alunos. Com autorização prévia dos participantes, as aulas eram gravadas e disponibilizadas pela professora em um canal na plataforma YouTube (Figura3).

O objetivo principal da criação do canal para depósito dos vídeos foi dar a possibilidade de que os discentes que não puderam, por algum motivo de força maior, comparecer à aula tivessem acesso ao conteúdo posteriormente, pois o momento da pandemia trouxe diversos reveses para o sistema ensinoaprendizagem.

Figura 3 - Canal da professora "Paula Nobre" no Youtube.

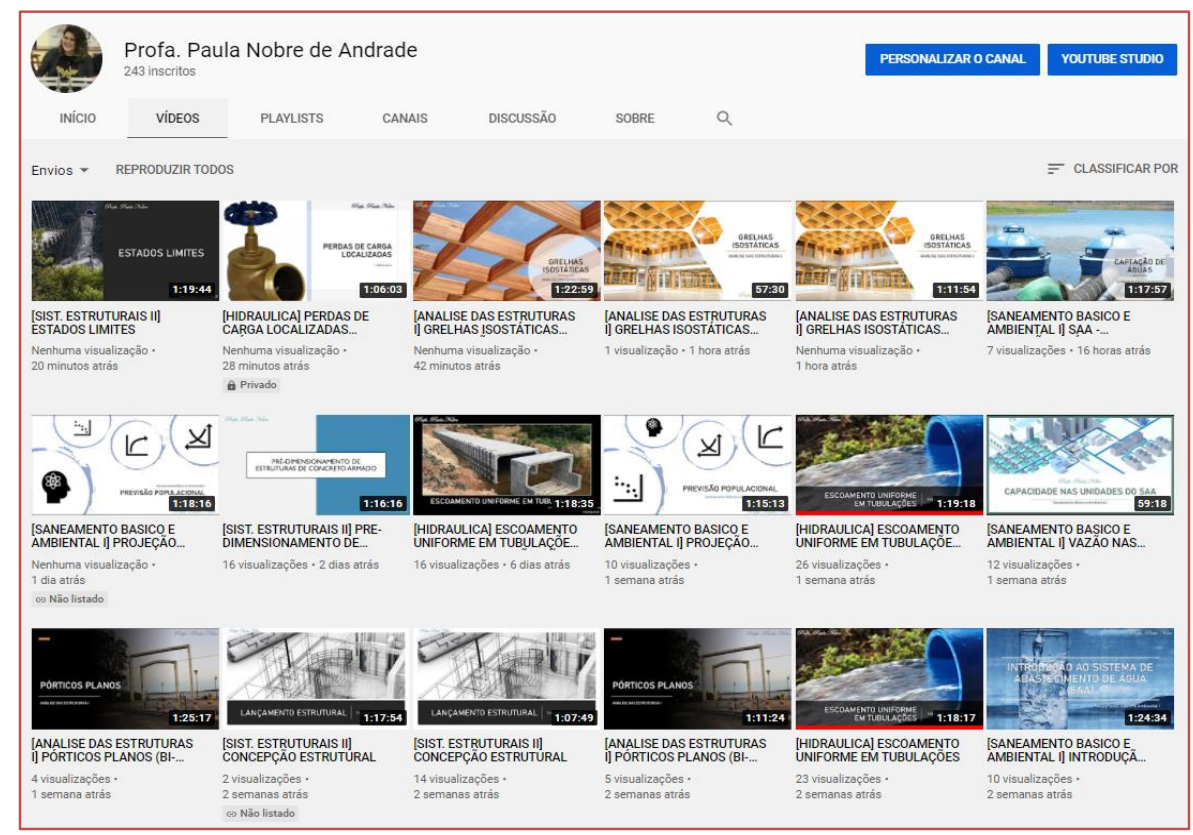

Fonte: Elaborado pelas Autoras (2020).

Entre as adversidades enfrentadas pelos discentes no decorrer das aulas da disciplina, as mais comuns foram problemas com a conexão com a internet e a falta de um ambiente adequado e silencioso em casa para que o aluno pudesse acompanhar as aulas.

A disciplina de Saneamento Básico e Ambiental I possui diversas vertentes a serem abordadas. De ementa variada, aborda dois dos quatro pilares do saneamento básico: abastecimento humano de água e drenagem urbana. Em virtude da necessidade de se realizar cálculos e discussões, a metodologia utilizada para a 
disciplina foi diversificar as ferramentas disponíveis: slides, mesa digitalizadora e softwares (EPANET, Redem.exe, Canais3, ABC6 e Microsoft Excel), conforme pode ser visto na Figura 4.

O uso da mesa digitalizadora durante as aulas mostrou-se crucial, pois a ação de interatuar através da escrita manual ao invés de apenas apresentar as informações digitadas em uma apresentação aumentou a interação entre a professora e a turma, incentivando a participação dos alunos e estimulando o aprendizado.

Figura 4 - Exemplos de aplicação da mesa digitalizadora nos slides das aulas.

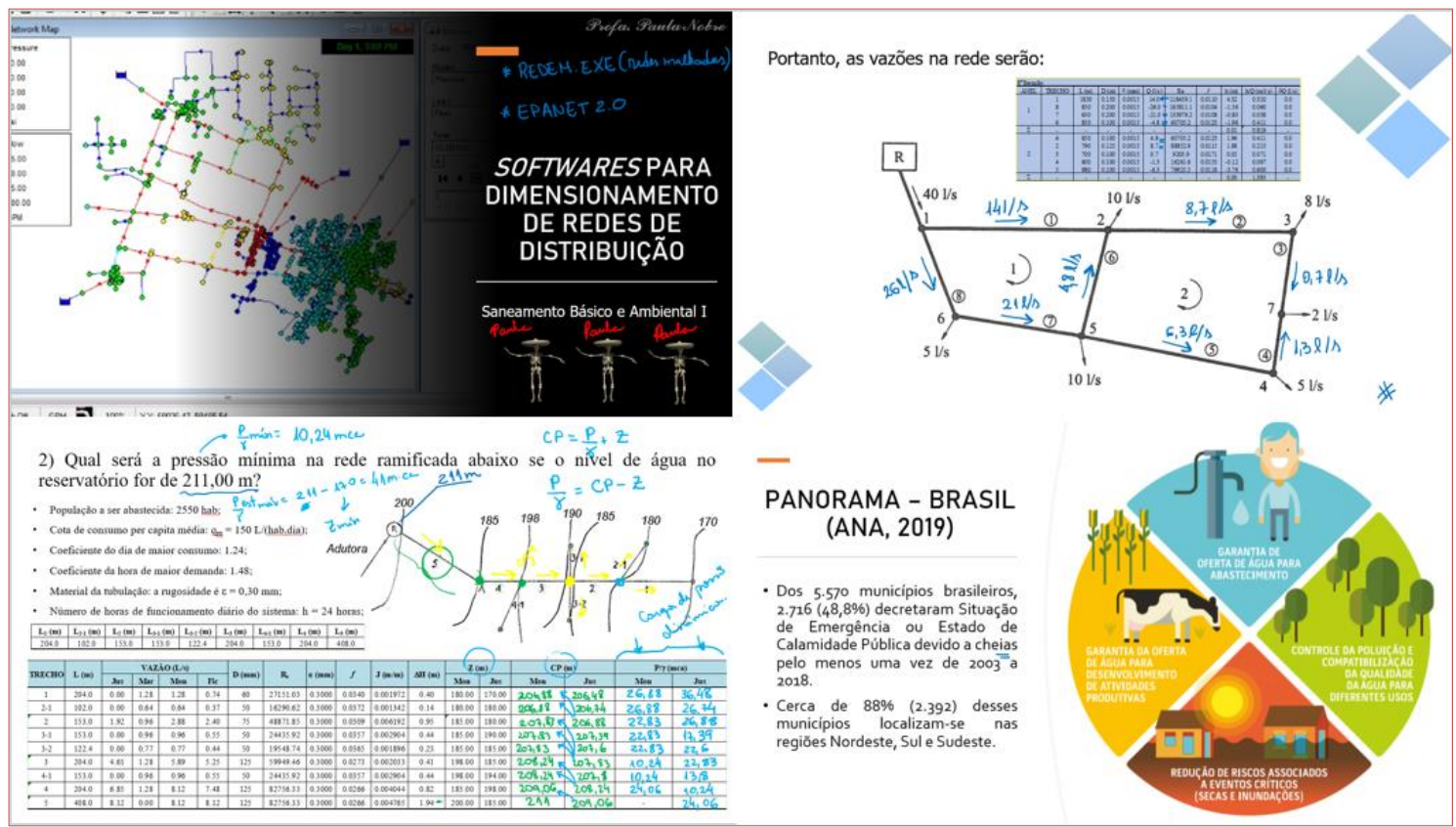

Fonte: Elaborado pelas Autoras (2020).

Além das ferramentas supracitadas, desenvolveu-se sessões intituladas como "Formação do Pensamento Crítico", onde os alunos eram instruídos a assistir vídeos de palestras de eventos internacionais relacionados aos assuntos vistos em aulas anteriores para elaborar redações elencando os conteúdos ministrados nas aulas e nas palestras.

\subsection{AVALIAÇÕES REMOTAS}

As avaliações da primeira etapa (NP1) ocorreram de forma presencial, no dia 12 de março de 2020. Logo após a aplicação da 1a avaliação parcial houve a mudança para o ensino remoto. As avaliações da segunda e da terceira etapas (NP2 e NP3) ocorreram de forma remota, através do ambiente virtual de aprendizagem da plataforma Moodle.

Por recomendações institucionais, cada questão da avaliação foi inserida em um questionário individual com tempo de disponibilidade definido de acordo com a complexidade da questão (Figura 5). 
Figura 5 - Questionários para aplicação de avaliação parcial.

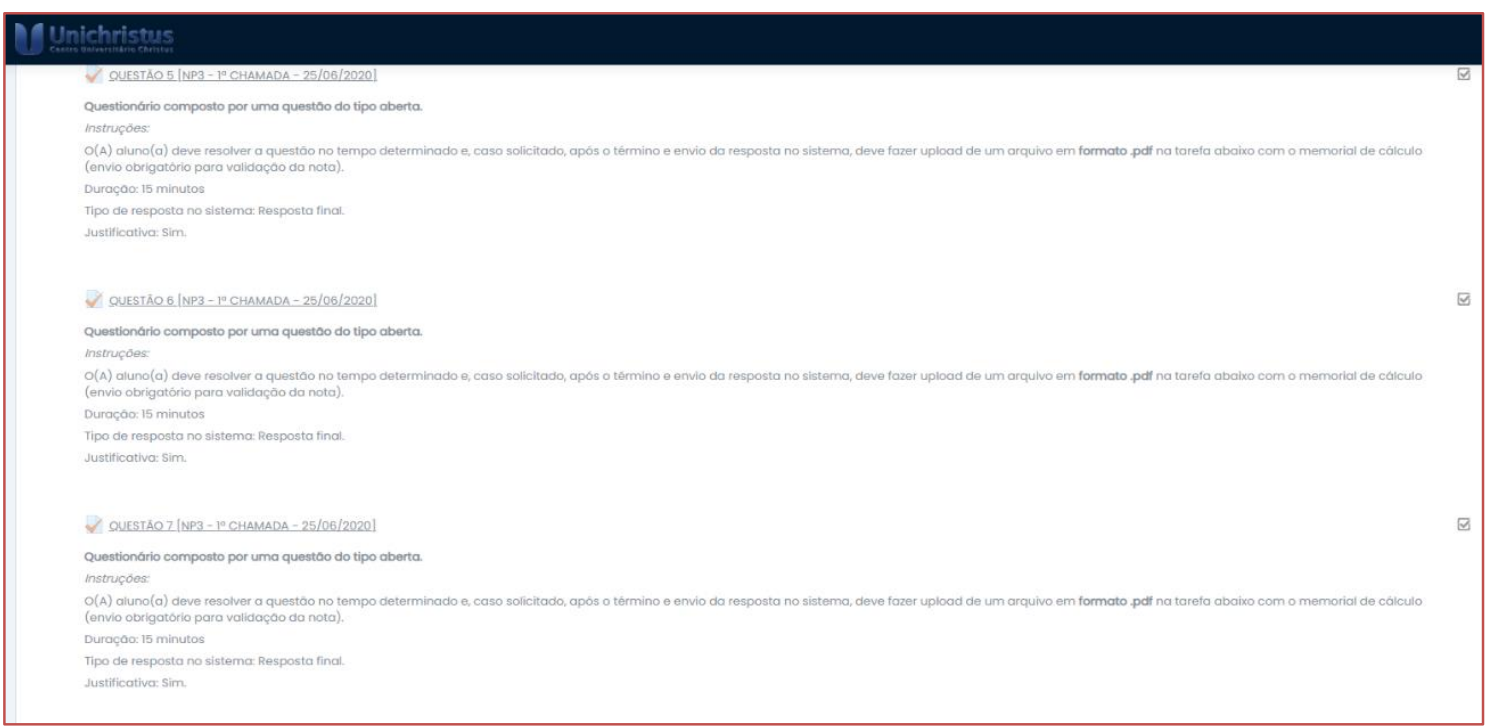

Fonte: Elaborado pelas Autoras (2020).

Os alunos tinham acesso a uma questão por vez e a resolução ia avançando de acordo com o término de cada um. As questões poderiam ou não necessitar de justificativa, que era enviada posterior ao término da prova para validação da nota.

A plataforma Moodle permite que o professor alterne a ordem de aparição das alternativas em questões de múltipla escolha e dispõe de questões de cálculo, onde é possível alternar valores para uma variável da questão. Dessa forma, as avaliações apareciam de forma individualizadas para cada aluno.

Além das avaliações parciais, também foram realizadas atividades complementares de interação como a produção de redações técnicas e aulas de exercícios em formato de gincana, onde os alunos ficavam com as câmeras ligadas e a professora lançava as perguntas em forma de desafio para estimular a participação e o estudo da matéria. Nessas atividades, constatou-se que houve mais adesão dos alunos aos exercícios propostos.

\subsection{CONCLUSÃO DA DISCIPLINA}

O gráfico exposto na Figura 6 mostra o resultado das avaliações da disciplina de Saneamento Básico e Ambiental I nas três etapas do semestre de 2020.1.

É possível notar que apenas um aluno, em 25, não concluiu a disciplina, sendo o único desistente do período. Pelos dados apresentados, é possível observar que a maioria da turma obteve desempenho de notas superior nas etapas onde o ensino foi ministrado de forma remota, pois é possível verificar que apenas dois alunos tiveram como melhor nota a NP1.

Na primeira etapa (NP1), a média da turma foi 6,9. Ao se analisar as notas individuais dos alunos com relação a essa média, tem-se que $36 \%$ da turma obteve nota abaixo e $64 \%$ turma obteve nota superior à média da etapa.

Na segunda etapa (NP2), a média da turma foi 7,3. Ao se analisar as notas individuais dos alunos com relação a essa média, tem-se que $44 \%$ da turma obteve nota abaixo e $56 \%$ turma obteve nota superior à média da etapa.

Na terceira etapa (NP3), a média da turma foi 8,0. Ao se analisar as notas individuais dos alunos com relação a essa média, tem-se que $36 \%$ da turma obteve nota abaixo e $64 \%$ turma obteve nota superior à média da etapa.

Quanto ao resultado definitivo da disciplina, após a média calculada, apenas um aluno não obteve a média exigida pela instituição para aprovação. 
Portanto, é válido considerar que a disciplina de Saneamento Básico e Ambiental I do Curso de Engenharia Civil do Centro Universitário Christus foi finalizada de forma exitosa, tenho sido cumprido 100\% da ementa com aprovação de $96 \%$ dos alunos.

Figura 6 - Resultado da disciplina por etapa/aluno.

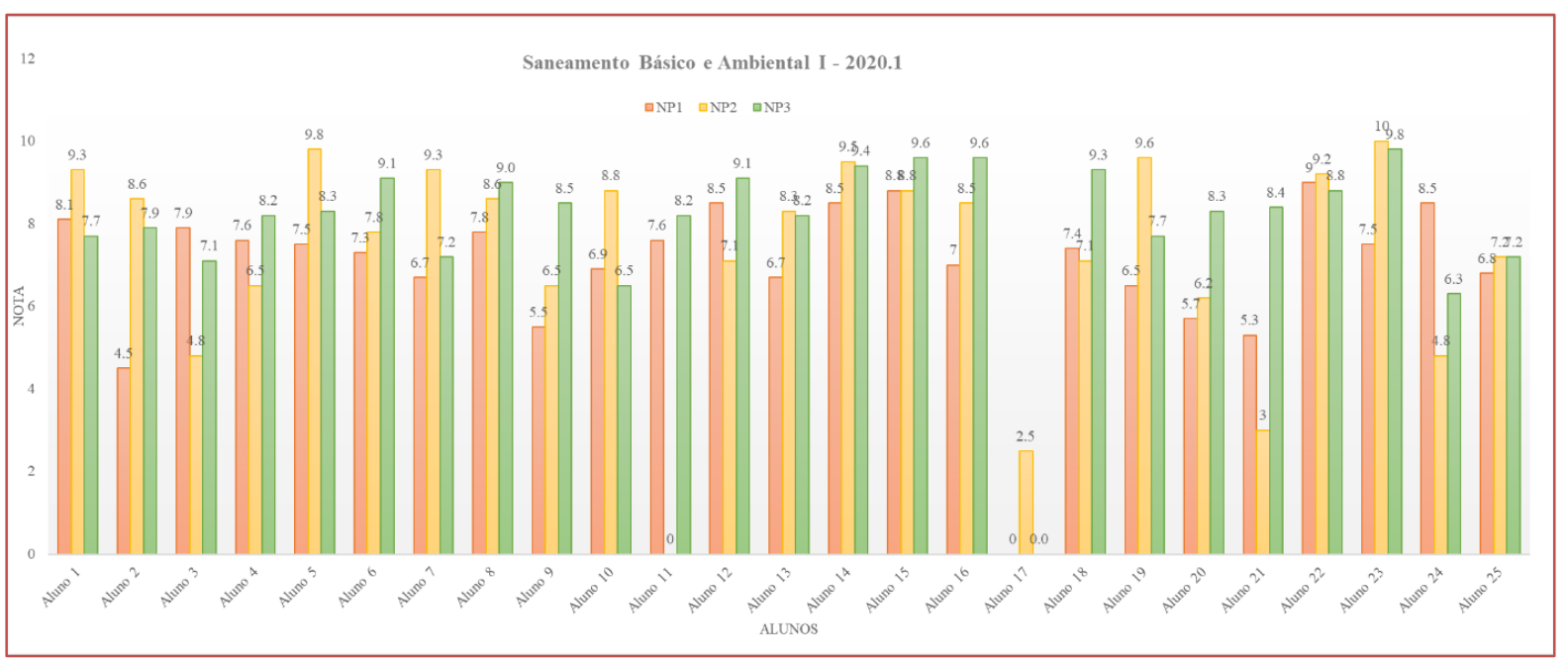

Fonte: Elaborado pela Autora (2020).

\subsection{FEEDBACK DOS ALUNOS}

Em meio à pandemia da COVID-19, todos os envolvidos no processo de ensino-aprendizagem (instituição, corpo docente e corpo discente) foram afetados, mesmo que minimamente, seja no âmbito emocional, financeiro, acadêmico etc. Com isso, após o final do semestre, alguns alunos se corresponderam de forma voluntária com a professora para expressar suas opiniões e impressões sobre o aprendizado na disciplina.

$\mathrm{O}$ aluno G.A.S.S agradeceu pelo conhecimento adquirido no semestre e disse que adorou as aulas, apesar da situação difícil. Disse ainda que espero cursar outra disciplina com a docente até o final do curso.

$\mathrm{O}$ aluno L.F.C.S parabenizou a professora pelo semestre e disse que "passamos por um momento bem difícil, mas você fez um trabalho excelente e contribuiu $1000 \%$ para nossa adaptação. A experiência com a disciplina só me fez gostar ainda mais da área".

Em consonância, a aluna A.S.G afirmou que foi a melhor disciplina do semestre e parabenizou a professora por ter se reinventado de maneira perceptível.

0 aluno T.G.S. agradeceu o rendimento do semestre em nome de um grupo de alunos, pois achou que "no geral, foi tudo muito bom, apesar da pandemia, não deixou a desejar em questão de conteúdo, de didática e o seu jeito de ser deixou as aulas muito dinâmicas".

Por fim, o aluno C.F.R.N parabenizou a professora pela organização do ambiente de ensino a distância, pois do jeito que o Moodle estava disposto era possível estudar perfeitamente, rever as aulas para sanar as dúvidas e aprender.

A professora aplicou, ainda, uma pesquisa de entendimento da realidade dos discentes da disciplina no ensino remoto. Essa pesquisa foi executada por meio de um formulário cadastrado no Google Forms e abordava questões gerais de infraestrutura e adaptação à nova modalidade de ensino.

Quanto à modalidade das aulas, $20 \%$ dos que responderam ao questionário preferem a modalidade de aulas remotas (com todos os discentes em casa), 27\% dos que responderam ao questionário preferem a modalidade de aulas híbridas (parte dos alunos em sala e parte dos alunos em casa) e 53\% dos dos que responderam ao questionário preferem a modalidade de aulas presenciais (com todos os alunos em sala).

Quanto à infraestrutura do discente no acesso à modalidade remota ofertada durante o semestre, todos que responderam ao questionário alegaram possuir internet em casa. Ressalta-se que $83 \%$ dos que 
responderam ao questionário costumam utilizar o smartphone para assistir as aulas, mesmo que apenas 7\% tenham informado que não possuem computador ou notebook disponível para assistir as aulas remotas.

Dos discentes que responderam ao questionário, 60\% consideram que as aulas na modalidade remota contribuem efetivamente para a sua formação profissional, o que implica que a qualidade aplicada no ensino remoto pode ser consagrada enquanto alternativa emergencial adotada. Destaca-se que $83 \%$ dos que responderam ao questionário preferem a modalidade de aula remota do tipo síncrona, ou seja, quando a aula é ministrada ao vivo no horário da disciplina.

Ademais, questionou-se quais eram as afinidades e as dificuldades encontradas pelos alunos no ensino remoto. As afinidades destacadas foram a possibilidade de rever as aulas gravadas para sanar dúvidas e a ausência da necessidade do deslocamento até a Unichristus, pois muitos alegaram morar longe e perder muito tempo nos transportes coletivo.

A Figura 7 mostra um quadro geral das maiores dificuldades apresentadas pelos discentes que responderam ao questionário. Nota-se que a ausência do ambiente escolar foi a dificuldade mais citada e essa característica engloba outras questões mais complexas: a dificuldade de concentração dos discentes em um ambiente diferente da sala de aula tradicional, a inexistência de um local adequado e destinado apenas para o acompanhamento das aulas, o conforto do lar (que muitas vezes contribui para a dispersão da concentração nas aulas) e a interposição de familiares e vizinhos na hora da aula. Além disso, os problemas de conexão foram apontados como uma dificuldade relevante, pois nem todos possuem suporte financeiro para a contratação de um pacote de internet que suporte vídeo chamadas diariamente e os serviços oferecidos pelas prestadoras desse serviço também se mostraram ineficientes em sua grande maioria.

Figura 7 - Dificuldades do ensino remoto.

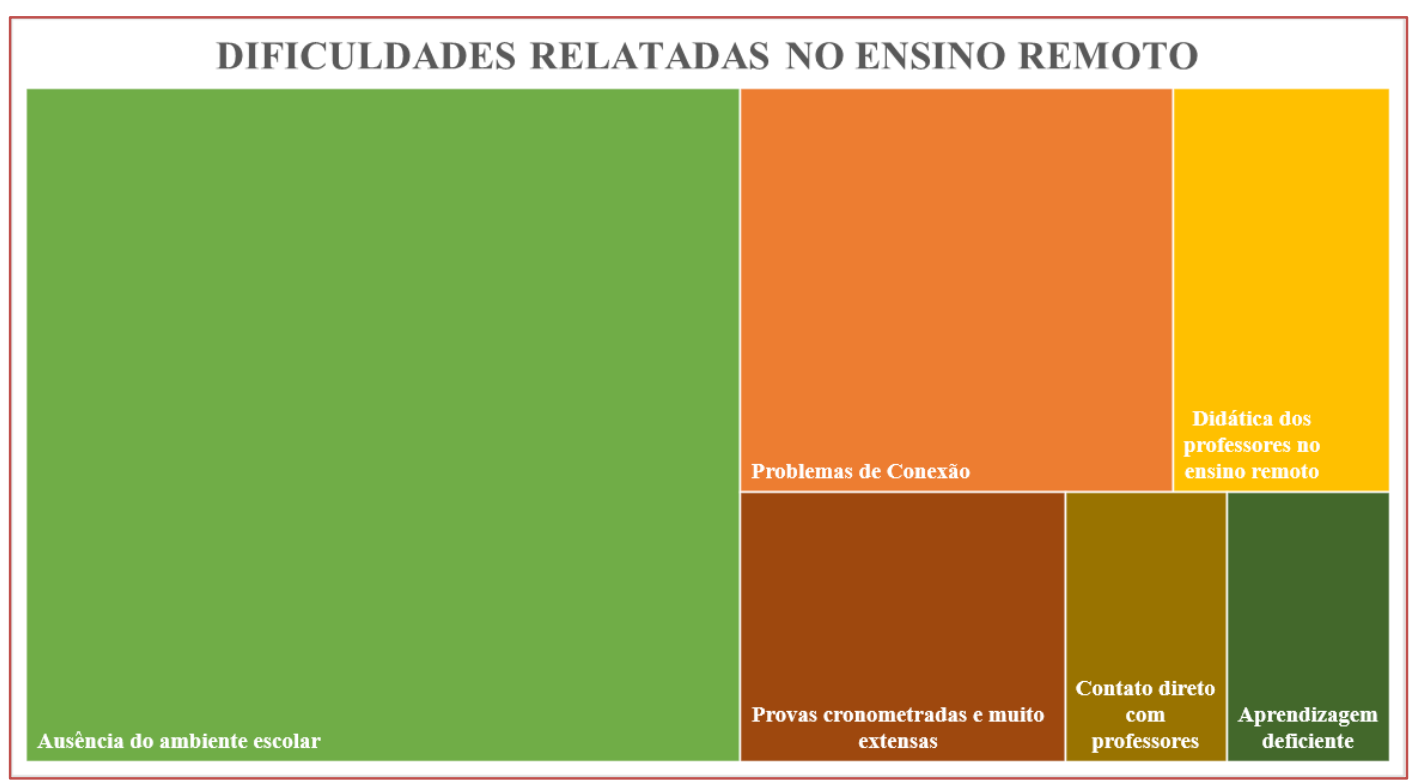

Fonte: Elaborado pelas Autoras (2020).

Por fim, as outras dificuldades relatadas pelos que responderam ao questionário foram: a didática de alguns professores no ensino remoto, a modalidade de avaliação aplicada, o contato direto com os professores e o comprometimento da aprendizagem devido aos diversos fatores supracitados. 


\section{CONSIDERAÇÕES FINAIS}

Esse trabalho tratou do relato de adaptação da disciplina de Saneamento Básico e Ambiental I, ofertada para o curso de Engenharia Civil do Centro Universitário Christus durante o período de isolamento social ocasionado pela pandemia da COVID-19.

Conforme apresentado, o ensino para o curso de Engenharia Civil já vinha sofrendo algumas exigências de modificações e adaptações ao teor mais tecnológico do curso por conta das novas diretrizes curriculares publicadas pelo Ministério da Educação. Contudo, as mudanças que seriam graduais foram executadas de forma abrupta por conta da crise na saúde pública mundial.

O que se observou no transcorrer do semestre é que a modalidade remota exigiu que o estudante de engenharia adquirisse um novo olhar sobre as metodologias ativas, o aprendizado por competências e o compromisso com a graduação, uma vez que o sistema de ensino e aprendizagem experienciou a inversão de valores e o professor assumiu o papel de tutor profissional, elevando a complexidade e o compromisso do aluno com sua formação.

\section{AGRADECIMENTOS}

Agradecimentos ao Centro Universitário Christus, na figura de todos que compõem as coordenações dos cursos de Arquitetura e Urbanismo, Engenharia Civil e Engenharia de Produção cujo apoio inexorável contribuiu para que o semestre pudesse ser finalizado com qualidade e motivação.

\section{REFERÊNCIAS}

[1] BRASIL, 2020. Ministério da Saúde. Painel de casos de doença pelo coronavírus 2019 (COVID-19) no Brasil. Disponível em: < https://covid.saude.gov.br/>. Acesso em: 30 jul. 2020

[2] CONSELHO NACIONAL DE EDUCAÇÃO. Institui as Diretrizes Curriculares Nacionais de Educação. Resolução no 2, de 24 de abril de 2019. Resolução CNE/CES 2/2019. Diário Oficial da União, Brasília, 26 de abril de 2019, Seção 1, pp. 43 e 44.

[3] FERRAZ, T. G. A.; LORDELO, S. N. B.; SAMPAIO, R. R. Avaliação dos estudantes: o que muda e como se adequar às novas diretrizes? In: ABENGE. A engenharia e as novas DCNs: oportunidades para formar mais e melhores engenheiros. Rio de Janeiro, 2019. P. 198-218.

[4] GOVERNO DO ESTADO DO CEARÁ. Palácio da Abolição. Decreta situação de emergência em saúde e dispõe sobre medidas para enfrentamento e contenção da infecção humana pelo novo Coronavírus. Decreto no 33.510, de 16 de março de 2020. Diário Oficial do Estado, Fortaleza, 16 de março de 2020, Série 3, Ano XII, no 053, Caderno 1/4.

[5] MINISTÉRIO DA EDUCAÇÃO. Gabinete do Ministro. Revoga a Portaria MEC no 4.049, de 10 de dezembro de 2004, e estabelece nova redação para o tema. Portaria no 1.134, de 10 de outubro de 2016. Diário Oficial da União, Brasília, 11 de outubro de 2016, Seção 1, pp. 21.

[6] MINISTÉRIO DA EDUCAÇÃO. Gabinete do Ministro. Dispõe sobre a oferta de carga horária na modalidade de Ensino a Distância - EaD em cursos de graduação presenciais ofertados por Instituições de Educação Superior - IES pertencentes ao Sistema Federal de Ensino. Portaria no 2.117, de 06 de dezembro de 2019. Diário Oficial da União, Brasília, 11 de dezembro de 2019, Seção 1, pp. 131.

[7] MORENO, M. L. R. De la Evaluación a la Formación de Competencias Genéricas: Aproximación a um Modelo. Revista Brasileira de Orientação Profissional, 7(2), P. 33-38, 2006.

[8] WHO - World Health Organization. Coronavirus Disease (COVID-19) Dashboard. 2020a. Disponível em: <https://covid19.who.int/>. Acesso em: 30 jul. 2020.

[9] WHO - World Health Organization. Coronavirus disease 2019 (COVID-19) Situation Report - 29. 2020b. Disponível em: < https://www.who.int/docs/default-source/coronaviruse/situation-reports/20200218-sitrep-29covid-19.pdf?sfvrsn=6262de9e_2>. Acesso em: 30 jul. 2020.

[10] ZABALA, A.; ARNAU,L. Como aprender e ensinar por competências. Porto Alegre: Artmed, 2010. 


\section{Capítulo 20}

O papel do tutor no desenvolvimento dos alunos: Cenários e desafios da Covid-19 no Ensino Superior

Alan Rangel Alves

João Paulo Tenório da Silva

Maria Ieda Monteiro

Mário Henrique Monteiro Nascimento

Priscila Débora Ramos

Rodrigo Barbosa Oliveira e Silva

Yuri Ravell Nobre Costa

Resumo : 0 presente trabalho tem como objetivo apresentar o cenário que os professores tutores enfrentaram nas IES (Instituição de Ensino Superior) nos meses de março a junho de 2020, devido à quarentena da COVID-19. Para a manutenção do período letivo, o semestre das aulas presenciais passou a ser online, momento em que a sala virtual de aprendizagem passa a ser valorizada perante a pandemia do novo coronavírus. Apresentaremos neste artigo um panorama que as IES caminharam por esta crise, desde treinamentos relâmpagos para professores, estratégias, ferramentas utilizadas pelos tutores e principalmente manter a normalidade e a qualidade das aulas.

Palavras-chave: COVID-19. Pandemia. Isolamento. Coronavírus. Tutor. Tutoria. Desenvolvimento do aluno. EaD. AVA. Sala de aula virtual. Aula Invertida. 


\section{CONSIDERAÇÕES INICIAIS}

A Educação a Distância (EaD), é uma modalidade de ensino que vem crescendo nas Instituições de Ensino Superior (IES), o número de vagas ofertadas aumenta a cada ano. Com base nos dados do Censo da Educação Superior 2017 do Instituto Nacional de Estudos e Pesquisas Educacionais Anísio Teixeira (INEP), é possível constatar os altos percentuais de matrículas em cursos de graduação a distância nas diversas regiões do país.

Figura 1 - Tabela de matrículas de cursos EAD no Brasil, de acordo com o Censo da Educação Superior 2017.

\begin{tabular}{|l|l|l|l|l|l|}
\hline \multirow{2}{*}{ Regiăo } & \multicolumn{4}{|c|}{ Matriculas } & \% das \\
& Total & \% do total & EAD & \% do total & instituiçōes \\
\hline Norte & 673.777 & $8,13 \%$ & 200.061 & $11,39 \%$ & $6 \%$ \\
\hline Nordeste & 1.746 .656 & $21,08 \%$ & 299.408 & $17,04 \%$ & $19 \%$ \\
\hline Sudeste & 3.705 .394 & $44,72 \%$ & 702.319 & $39,98 \%$ & $41 \%$ \\
\hline Sul & 1.388 .211 & $16,75 \%$ & 389.926 & $22,20 \%$ & $23 \%$ \\
\hline Centro-Oeste & 772.300 & $9,32 \%$ & 164.943 & $9,39 \%$ & $11 \%$ \\
\hline Total & 8.286 .338 & $100 \%$ & 1.756 .657 & $100 \%$ & $100 \%$ \\
\hline
\end{tabular}

Fonte: Censo 2018 ABED

A EaD teve início com a rádio educação, passou pelo ensino por correspondência, teve a fase da teleeducação, e a partir da década de 1990, chega com o uso da internet, onde outros recursos são apropriados como videoconferências, e em 2002 as Instituições de Ensino Superior começaram a adesão a esta modalidade.

Carlini e Tarcia (2010) "acreditam que o diálogo entre professores e alunos é uma possibilidade concreta de construção coletiva e colaborativa de novas práticas pedagógicas, coerentes com o momento sóciohistórico no qual estamos inseridos". Reconhecida mundialmente como uma possibilidade de profissionalização em nível superior de ensino, a EaD protagoniza nos dias atuais uma tendência. Suas potencialidades síncronas e assíncronas de estudo, atendimento e orientação, fazem parte do cotidiano contemporâneo e seguem o avanço tecnológico, como também sua popularização.

Na obra 'A ética na pesquisa social: da perspectiva prescritiva à interanimação dialógica', Mary Jane Spink, analisa aspectos que influenciam no modo como as pessoas se relacionam consigo mesmas e com o mundo atual, e que interferem fortemente nos processos de aprendizagem. E um desses aspectos é a globalização.

Para Giddens (1998) (apud SPINK, 2000), a globalização refere-se à interseção da presença e da ausência, ao cruzamento de eventos e relações sociais que estão longe dos contextos físicos locais que transcendem os limites de tempo-espaço, no que concerne ao movimento das pessoas, produtos e informação; que passaram a ser facilitados tendo em vista os avanços dos transportes e dos meios de comunicação.

Por isso, nas áreas de tecnologias de informação, a comunicação na educação a distância (EaD) é sem dúvida representada pelo professor tutor, pois ele assume o papel de mentor para o aluno. Além do docente ou tutor, existem também outros papéis importantes no Ambiente Virtual de Aprendizagem (AVA), como o coordenador do curso, equipe técnica, secretaria e a ouvidoria.

Entre os meses de março a junho, com a quarentena imposta pela pandemia da COVID-19, Instituições de Ensino Superior de todo o mundo, se depararam com uma situação que trouxe a necessidade de se reinventar mais uma vez e remodelar rapidamente todo um planejamento desenvolvido para o semestre 2020.1 .

Como conduzir o processo de ensino-aprendizagem de forma completamente online e o mais importante, manter a mesma qualidade do presencial?

Neste artigo, iremos apresentar um compilado de métodos e experiências que Instituições de Ensino Superior desenvolveram e adotaram para se adaptar às mudanças repentinas acarretadas pela COVID-19, e tentar garantir a qualidade no desenvolvimento das atividades de ensino-aprendizagem com o apoio do professor tutor, através da plataforma AVA. 


\subsection{EAD NO ENSINO SUPERIOR NO BRASIL}

Considerada jovem, a EaD no Ensino Superior é normatizada no Brasil pela Lei no 9.394/96, em todos os níveis e modalidades de ensino, e de educação continuada, sendo normatizada na Portaria Ministerial n.oㅡ 4.361, de 2004, sobre o credenciamento e recredenciamento dos cursos presenciais e EaD. No ano seguinte com o Decreto n.o 5.622, publicado no D.O.U. de 20/12/05, regulamenta o art. 80 da Lei n o 9.394, de 20 de dezembro de 1996, que estabelece as Diretrizes e Bases da Educação Nacional, sobre a EaD, e a Resolução CNE/CES no 1, de 3 de abril de 2001, estabelece normas para o funcionamento de cursos de pós-graduação.

De acordo com o Ministério da Educação do Brasil - MEC:

A Educação a Distância é a modalidade educacional na qual a mediação didáticopedagógica nos processos de ensino e aprendizagem ocorre com a utilização de meios e tecnologias de informação e comunicação, com estudantes e professores desenvolvendo atividades educativas em lugares ou tempos diversos. (EDUCAÇÃO Superior a Distância, portal.mec.gov.br, 2018).

As Instituições de Ensino Superior (IES) dispõem de metodologias e ferramentas por meio de plataformas de ensino, que permitem a comunicação e o relacionamento dos alunos com o professor, tutor, coordenador e com a administração da instituição. As IES que oferecem cursos de graduação EaD têm acompanhado todo esse processo de inovação, de qualidade do ensino e de construção do conhecimento. Saindo de um processo de ensino-aprendizagem baseado na transmissão de informação, para um processo de aprendizagem em que os alunos aprendem o que estudaram e sua aplicação na prática, como, por exemplo, aplicação do conhecimento adquirido em estudos de casos, resolução de problemas.

\subsection{QUALIDADE DE ENSINO COM O ALUNO}

A discussão sobre o ensino envolve diversos fatores, desde a gestão escolar, organização pedagógica, estrutura da instituição, até mesmo o perfil social dos alunos. Com essa compreensão, Dourado e Oliveira (2009), defendem que a qualidade da educação envolve o espaço institucional de produção e de disseminação do conhecimento, de modo sistemático e envolve também outros atores formativos, como as famílias e sociedade.

Para alcançar resultados positivos no ensino, vários fatores precisam estar sincronizados, como as práticas educativas e exigências sociais. Isso implica na leitura do cenário atual e perspectivas futuras do mundo.

Gusmão (2007), entende que falar em qualidade da educação implica atribuir juízos de valor a aspectos ou resultados do processo educativo, como também aos objetivos educacionais.

A educação é construída com a participação de todos, gestores públicos ou privados, envolvimento da comunidade escolar e das famílias em prol de alcançar o objetivo do desenvolvimento humano para se tornarem bons cidadãos. Ao contrário do estudo espontâneo e individual, ou das aulas tradicionais desenvolvidas nas instituições de ensino, na modalidade EaD o processo de ensino-aprendizagem precisa ter um apoio.

Para Maia e Mattar (2007), esse apoio deve incluir o acompanhamento da aprendizagem por um professor tutor, e não somente a produção de bons conteúdos seja a sua única função educacional.

A modalidade EaD dispõe de diversas formas de interação, seja por texto, áudio ou vídeo, e para uma melhor experiência com estas ferramentas, tanto os docentes como os discentes precisam ser preparados para utilizar todos os recursos que a plataforma disponibiliza. Outro fator importante é a escolha do modelo pedagógico que a instituição pretende adotar de acordo com o perfil do profissional que a organização deseja desenvolver.

Para superar a distância entre alunos e professores, no tempo e no espaço, a EaD, utiliza-se de diversas ferramentas de comunicação (MAIA e MATTAR, 2007). O papel do professor neste momento se torna fundamental para o melhor desenvolvimento das atividades acadêmicas, todo o seu esforço será recompensado com os resultados finais positivos.

Silvia (2017) destaca que essa nova realidade exige principalmente do professor tutor um maior preparo para que as atividades acadêmicas possam ser desenvolvidas com qualidade no resultado final e formação integral do indivíduo.

A estratégia no processo de ensino-aprendizagem da EaD deve levar em consideração os recursos tecnológicos disponíveis pelos alunos, para que assim todos possam interagir e efetivar a aprendizagem. 0 
aluno e o professor online precisam realizar uma interação e não apenas uma recepção de conteúdo. Portanto, aprender a trabalhar diversas ferramentas de interação, torna-se uma vantagem competitiva no mercado atual.

\subsection{PROFESSOR TUTOR E O PANORAMA DA INTERAÇÃO COM ALUNO}

$\mathrm{Na} \mathrm{EaD}$ o aluno adquire conhecimento por meio de ferramentas assíncronas com leituras de livros, artigos, assistem vídeos, realizam exercícios online no Ambiente Virtual de Aprendizagem (AVA), com foco em compreender, recordar e fixar os conceitos inerentes à sua área de estudos. Segundo Vavassori e Raabe (2003, p.312), um ambiente virtual de aprendizagem é um sistema que reúne uma série de recursos e ferramentas, permitindo e potencializando sua utilização em atividades de aprendizagem através da internet em um curso a distância.

0 crescente desenvolvimento da tecnologia de redes de computadores, com o aperfeiçoamento dos meios de comunicação, dos protocolos e das técnicas de processamento distribuídos chamam a atenção para o uso de recursos de sistemas distribuídos com finalidades de ensino aprendizagem (GIRAFFA, 1999).

Para Machado (2000), os Ambientes Virtuais de Aprendizagem ou Sistemas de Gerenciamento para Ensino a Distância, ou do inglês IMS - Instructional Management System são formados por um conjunto de ferramentas para a construção e disponibilização de material instrucional. Nos cursos que envolvem Educação a Distância, podemos encontrar atividades que demandem a presença simultânea dos alunos e tutores. Apesar de ir contra as facilidades de EaD, como fazer o seu próprio horário, algumas dessas atividades são necessárias.

Quando dizemos que alguma atividade é síncrona, significa que tanto alunos como professores precisam estar no mesmo horário realizando a atividade, seja ela física ou virtual. 0 oposto das atividades síncronas engloba o que chamamos de assíncrono, que é o modelo usado na metodologia EaD. Esse modelo de atividade é o que mais atrai os alunos interessados em flexibilidade de tempo, pois não existe a necessidade dos alunos e tutores estarem no mesmo local (físico ou virtual) e horário.

Os chamados fóruns são muito parecidos com os chats, em que os participantes de um curso EaD podem trocar mensagens de texto como forma de se comunicar. Mas a grande vantagem do fórum é a sua natureza assíncrona. Os participantes podem publicar mensagens que ficam disponíveis por tempo indeterminado. Essas mesmas mensagens podem eventualmente ser usadas como forma de avaliação pelos professores ou tutores.

Por exemplo, um curso pode ter fóruns que sejam destinados à discussão de um texto polêmico, ou mesmo ser usado como forma de ajuda entre a equipe técnica e os alunos. Pode ainda ser utilizado para resolver problemas colaborativamente (em estudos de caso). A interação e pró-atividade que a metodologia demanda dos participantes acaba moldando pessoas e profissionais que não têm medo de aprender, pesquisar e encarar desafios.

Todas as qualidades que são caçadas e disputadas por empresas e corporações hoje em dia e são também o pilar para os empreendedores. Nas metodologias em que o foco do aprendizado não é o aluno, a postura passiva que é tradicional nesses ambientes torna muito mais difícil que essas características sejam desenvolvidas. Como a grande maioria das pessoas se forma em cursos presenciais, o resultado é que apenas poucas pessoas com aptidão natural ou que tiveram a orientação correta acabam desenvolvendo esse tipo de qualidade.

A webconferência serve para comunicação síncrona através da Internet, ou seja, o professor executor da disciplina, o tutor e os alunos se encontram em uma "sala virtual online", em um horário agendado, para discutirem um mesmo assunto. Nas aulas, o professor apresenta um conteúdo utilizando slides e interage com os alunos, pedindo a colaboração deles através de perguntas direcionadas ou enquetes.

No AVA também é disponibilizado um formulário de contato com o professor, chamado "Contato" ou "Fale com o Tutor" o aluno tem um canal de comunicação com a tutoria desta disciplina. Em caso de dúvidas pedagógicas (conteúdo das aulas, propostas das atividades, avaliações).

0 tutor EaD é o professor que ensina os alunos através de uma tutoria a distância. Ele nada mais é do que o profissional que tira dúvidas direciona conteúdos, corrige provas e exercícios e, muitas vezes, também produz o conteúdo pedagógico.

\section{MÉTODO}


Os métodos utilizados na pesquisa tiveram a combinação da observação indireta e dados descritivos. Também foram utilizados os métodos de pesquisa indutiva, pesquisa qualitativa e dados empíricos.

No novo cenário enfrentado por diversas IEs provocado pela COVID-19, a partir da segunda quinzena do mês de março de 2020, foi necessário que as mesmas se adaptassem à nova realidade online. Utilizando a estratégia para suspender temporariamente as aulas do presencial no bimestre e migrar para a sala de aula invertida, ou seja, o aluno acessa o conteúdo da sua aula através da sala virtual (AVA), e o professor tutor disponibiliza um canal para comunicação em webconferência nos mesmos horários que ocorriam as aulas presenciais.

A suspensão das aulas presenciais foi uma medida de isolamento do grupo contingente de alunos na sala de aula, dado o risco da sua saúde. 0 método, que objetivou garantir a disponibilidade do conteúdo digital para o aluno com o mesmo nível de excelência que a instituição exige no presencial, tornou urgente e em curto espaço de tempo, transformando a rotina dos professores e também a todos os colaboradores das IES.

O plano na decisão para agilidade se efetivou em treinamentos virtuais com todo o corpo docente e para todos os discentes, além de testes de novas ferramentas e tecnologias aliadas ao ensino-aprendizagem, evidenciando o papel do tutor no desenvolvimento dos alunos.

\section{DESENVOLVIMENTO}

A mudança de rotina, obrigou as IES a tomarem medidas, como a redução de carga horária ou trabalho home office, através de critérios e particularidades de saúde de cada colaborador na instituição. Todos os professores também trabalharam em suas casas, fazendo o uso excepcional em sala de aula ou laboratório no apoio de gravação de videoaulas para apresentação das aulas práticas. Contudo, as ações trabalhistas foram medidas pelo Congresso Nacional na legislação do setor do Ensino Superior em função das Medidas Provisórias № 927, de 2020 e 936, de 2020.

\subsection{TREINAMENTO COM PROFESSORES DO PRESENCIAL}

Professores tutores habituados com o ensino online, equipe técnica da EaD, departamentos de TI (Tecnologia da Informação), e até mesmo empresas de consultoria EaD, desenvolveram treinamentos de videoconferência apresentando o AVA e ferramentas de comunicação com os alunos, para todos professores que estavam habituados com as aulas presenciais.

As transformações na relação de trabalho, na sociedade, exigem mudanças em relação à educação, e é preciso formar pessoas capazes de lidar com problemas desconhecidos, lidar com o inesperado e com a incerteza (MORIN, 2000).

Nesse processo de "alfabetização digital" e ferramentas tecnológicas no contexto ensino online, é disponibilizado para toda comunidade acadêmica da rede e constam todas as disciplinas do corpo discente e docente, cuja inserção do conteúdo e mediação no processo ensino-aprendizagem é administrada pelo professor da disciplina e ou tutor. A plataforma é utilizada também para as atividades de disciplinas on-line, cuja mediação é própria do professor-tutor.

\subsection{TECNOLOGIAS E ESTRATÉGIAS NA APLICABILIDADE}

As transformações tecnológicas pelas quais a sociedade tem passado, nos últimos anos têm requerido dos educadores nova postura e reflexão sobre a prática docente. A mudança é emergencial e todos os setores precisam estar envolvidos para que a mudança ocorra da maneira mais eficiente possível.

Para Moran (2007, p.167) a educação que desejamos hoje, tem que surpreender, cativar, conquistar os estudantes a todo o momento. A educação precisa encantar, entusiasmar, seduzir, apontar possibilidades e realizar novos conhecimentos e práticas. 0 conhecimento se constrói a partir de constantes desafios, de atividades significativas, que exercitem a curiosidade, a imaginação e a criatividade.

Como planejamento emergencial, observando o direcionamento legal e institucional, com o objetivo de alinhar a comunicação ágil e eficiente com os alunos e corpo docente. Estabelecendo, dessa forma, programação minuciosa e organização de processos para o momento de ambientação no uso do AVA institucional, ambiente onde estudante e professor passam a acessar desde o início do período letivo, e que 
com a impossibilidade do presencial, passou a concentrar a continuidade dos processos pedagógicos quase que em sua totalidade.

As videoconferências ou videochamadas utilizadas através do aplicativo Zoom (Zoom Cloud Meetings) e Hangouts Meet pelos professores tutores, direcionadas à ambientação dos calouros, aula online, esclarecimento de dúvidas fizeram parte da nova rotina, garantindo assim, a qualidade dos processos pedagógicos, e, evitando evasões. Foram táticas e ações conduzidas pela direção e coordenação de muitas IES, que seguiram os protocolos legais e institucionais em nível nacional.

Outras aplicabilidades no ensino remoto:

Figura 2 - Tabela de estratégias EaD aplicadas pela Faculdade Pitágoras de Jaboatão dos Guararapes - PE.

\begin{tabular}{|c|l|}
\hline WhatsApp & Intensificação de acompanhamento via aplicativos de smartphones. \\
Videoaulas & Gravação de vídeo aulas dos professores da modalidade presencial. \\
\hline Eventos online & $\begin{array}{l}\text { Desenvolvimento de Semana Virtual, com lives de tutores e professores sobre } \\
\text { vários temas de relevância social, abertas ao público geral e com certificação. }\end{array}$ \\
\hline Lives dos tutores & $\begin{array}{l}\text { Direcionadas às turmas as quais acompanhava, para o desenvolvimento de } \\
\text { atividades pedagógicas rotineiras e esclarecimento de dúvidas. }\end{array}$ \\
\hline Provas online & $\begin{array}{l}\text { Aplicação de avaliações presenciais via online, obedecendo aos critérios das } \\
\text { normatizações vigentes. }\end{array}$ \\
\hline Material Pedagógico & Adequação de material pedagógico. \\
\hline
\end{tabular}

Fonte: 0 autor (2020)

O calendário acadêmico junto com os feriados antecipados por decisão em cada região e estado nacional proposta pela câmara de vereadores, Lei 1335/19, trouxe a flexibilização na aplicação das avaliações no formato online foram essenciais, observando os critérios legais e institucionais deste período atípico.

\subsection{DESENVOLVIMENTO DO ALUNO}

Observando um trecho da definição utilizada pelo Ministério da Educação, no Decreto - Lei 2.494 de 1998, Educação a distância seria "uma forma de ensino que possibilita a autoaprendizagem, com a mediação de recursos didáticos sistematicamente organizados [...]”. (Decreto n. ํㅜ 2.494, de 10 de fevereiro de 1998, portal.mec.gov.br, 1998, s.p.).

Saber onde buscar o conhecimento adequado e se apropriar dele, aplicando-o na resolução dos problemas, são habilidades fundamentais aos estudantes nos processos formativos da contemporaneidade.

E na EaD também é fundamental acompanhar de perto os estudantes. Educação é viver, experienciar, é interagir. E tudo isso ganha sentido, à medida que os tempos também vão mudando. Para Maturana (1998, p. 45) “(...) a aprendizagem é um processo que se estabelece no viver (...) aprender é mudar com o mundo".

Nessa perspectiva, um dos grandes desafios é tentar compreender como as transformações da sociedade no mundo globalizado vêm influenciando no modo como as pessoas aprendem, bem como manter o desejo delas de aprender. Nessa direção, estudar representa um dinamismo constante no que se refere às técnicas e metodologias inovadoras, bem como as formas de organizar e desenvolver os estudos por parte dos alunos. Estes são alguns dos desafios que o tutor EaD enfrenta.

\subsection{RETORNO PARA O ENSINO PRESENCIAL}

Após o período de isolamento social, uma nova realidade aguarda estudantes, professores, gestores escolares e profissionais de suporte à educação. 0 que este cenário permite deduzir, até o momento, é que nada será como antes para os profissionais da educação, uma vez que esta crise terá efeitos sobre as novas formas de educar e de aprender com a revisão de processos, estruturas e metodologias. 
A imprevisibilidade nos mostrou de forma mais contundente possível que o trabalho em grupo se torna essencial e diante do atual cenário em que professores, antes tradicionais, sem o uso frequente de ferramentas tecnológicas ou Ambientes Virtuais de Aprendizagem, se viram na necessidade de adotar tais ferramentas para o trabalho habitual.

E, dentre os atores envolvidos nos processos de ensino-aprendizagem, os tutores ganharam grande destaque nesse momento, por já possuírem grande familiaridade com estas ferramentas. Foram capazes de acelerar as práticas educacionais através de colaboração, flexibilidade, inclusão e responsabilidade, uma vez que, o trabalho desempenhado pelos tutores visa a excelência no atendimento às demandas dos alunos, para que o processo de aprendizado seja realizado com qualidade, conformidade, tempestividade e eficiência.

Isso inclui métodos e práticas de ensino-aprendizagem que incorporam o uso integrado de tecnologias de informação e comunicação para a realização dos objetivos pedagógicos, visando a excelência no atendimento às demandas dos alunos e o êxito acadêmico.

De acordo com o governo de São Paulo o retorno das aulas presenciais previsto dia 08 de setembro de 2020 para regiões da fase amarela, no reinício as salas terão ocupação máxima de 35\% e respeitado as diretrizes impostas pelo MEC (Ministério da Educação). Além do rodízio na prevenção nos cuidados da saúde, e às medidas e regras exigidas. A preferência dos alunos ao retorno às aulas presenciais pode ser considerada como uma preocupação para aqueles que precisam das aulas práticas presencialmente e finalizar o seu curso.

No cenário pós-pandemia, inúmeras transformações ocorreram.

Uma delas é que a importância das habilidades necessárias à nossa adequação para o futuro que está por vir precisou ser reforçada de maneira mais acelerada, porém, a grande lição pós-pandemia é, sem dúvidas, a adaptabilidade de novas tecnologias de ensino, e que a partir desse momento, precisaremos incrementálas em nosso cotidiano e todos os atores envolvidos no processo de educação precisarão aprender a se desenvolver e construir uma autonomia cada vez maior; autonomia propiciada pela tecnologia e grande parte facilitada pelo papel da tutoria.

\section{CONSIDERAÇÕES FINAIS}

Com o avanço da tecnologia da informação, da globalização, e evolução do uso da internet na vida cotidiana, foi possível perceber também a mudança de comportamento na sociedade. Inúmeros setores da Economia, questões de empregabilidade, como também a Educação, foram surpreendidos pela inesperada pandemia; a qual veio acelerar essa transformação. No contexto em tela, a atuação do tutor apresenta-se de fundamental importância para o sucesso os estudantes em sua experiência EaD. Antes e depois da pandemia da COVID-19.

Estar preparado para lidar com mudanças sociais repentinas e grupos heterogêneos de alunos sob vários aspectos: autonomia e organização para o estudo, motivação, níveis de habilidade com as tecnologias, expectativas e exigências quanto à EaD, diferentes faixas etárias, subjetividade, são fatores que permeiam profundamente a prática deste profissional.

Cada momento de orientação junto aos alunos deve ser encarado pelo tutor como uma oportunidade única e de ensino-aprendizagem e também de aprimoramento da sua própria prática. É importantíssimo vivenciála de forma intensa. Torna-se imperativo tentar compreender a singularidade de cada um. Sendo essencial para o educador, realizar seu trabalho com um olhar diferenciado sobre a Educação, que vai além de notas, rotinas burocráticas e certificações.

No tocante ao desenvolvimento de suas atividades, o tutor EaD precisa estar sempre atento a um elemento fundamental, inerente a toda atividade que necessita da interação entre pessoas, a afetividade. Estar 'próximo', mesmo que de forma virtual, atenção, paciência, devem permanecer enquanto premissas. Antes e depois de qualquer pandemia.

E a gratidão demonstrada pelos alunos, mesmo quando as coisas não dependem totalmente de você, não tem preço! Nesse sentido, é de se considerar o tutor EaD como um profissional que carrega em sua prática a esperança de processos educacionais cada vez mais humanizados, e com perspectiva de sucesso cada vez ampliada para os estudantes, mesmo em tempos de distanciamento social intenso e generalizado.

\section{REFERENNCIAS}

[1] CARLINI, Alda; TARCIA, Rita Maria. 20\% a distância: e agora?: Orientações práticas para o uso de tecnologia de educação a distância. São Paulo: Pearson Education do Brasil, 2010. 
[2] CENSO EAD.BR 2018. Relatório analítico da aprendizagem a distância no Brasil. Associação Brasileira de Educação a Distância (ABED). 2018. Editora InterSaberes. Disponível em: <http://abed.org.br/arquivos/CENSO_DIGITAL_EAD_2018_PORTUGUES.pdf >. Acesso em: 16 de abr. de 2020.

[3] CORONAVÍRUS. MEC autoriza ensino a distância em cursos presenciais. portal.mec.gov.br. 2020. Disponível em: $\quad$ <http://portal.mec.gov.br/busca-geral/12-noticias/acoes-programas-e-projetos-637152388/86441-mecautoriza-ensino-a-distancia-em-cursos-presenciais>. Acesso em: 07 de jun. de 2020.

[4] DECRETO n.o 2.494, de 10 de fevereiro de 1998. portal.mec.gov.br. 1998. Disponível em em: <http://portal.mec.gov.br/seed/arquivos/pdf/tvescola/leis/D2494.pdf>. Acesso em: 10 de jun. de 2020.

[5] DECRETO no 9.057, de 25 de maio de 2017. Regulamenta o art. 80 da Lei no 9.394, de 20 de dezembro de 1996, que estabelece as diretrizes e bases da educação nacional. planalto.gov.br. 2017. Disponível em: <http://www.planalto.gov.br/ccivil_03/_ato2015-2018/2017/decreto/D9057.htm >. Acesso em: 09 de maio de 2020.

[6] DOURADO, Luiz Fernando; OLIVEIRA, João Ferreira. A qualidade da educação: perspectivas e desafios. Cadernos CEDES, Campinas, v. 29, n. 78, Mai/Ago. 2009. Disponível em: <https://www.scielo.br/scielo.php?pid=s0101$32622009000200004 \&$ script=sci_arttext $>$. Acesso em: 30 de jul. de 2020.

[7] EDUCAÇÃO Superior a Distância. portal.mec.gov.br. 2018. Disponível em: <http://portal.mec.gov.br/instituicoes-credenciadas/educacao-superior-a-distancia>. Acessado em: 28 de jul. de 2020.

[8] GIRAFFA, L.M.M. Uma arquitetura de tutor utilizando estados mentais. 177f. Tese. (Doutorado em Ciência da Computação) - Universidade Federal do Rio Grande do Sul, Porto Alegre. 1999.

[9] GUSMÃO, Joana Buarque. A construção da noção de qualidade da educação. Ensaio: Avaliação e Políticas Públicas em Educação. Rio de Janeiro, v. 21, n. 79, p. 299-322, Abr/Jun. 2013.

[10] MACHADO, H. A. P. Júlio. Sistemas de Gerenciamento para Ensino. Dissertação de mestrado. Porto Alegre, maio de 2000. MAIA, Carmem; MATTAR, João. ABC da EaD: A educação a distância hoje. São Paulo: Pearson Prentice Hall, 2007.

[11] MATURANA, Humberto. Da biologia à psicologia. Porto Alegre: Artes Médicas, 1998.

[12] MEDIDA Provisória $n^{\circ}$ 927, de 2020 (Medidas trabalhistas para enfrentamento da emergência de saúde pública decorrente do Coronavírus). Congresso Nacional. 2020. Disponível em: <https://www.congressonacional.leg.br/materias/medidas-provisorias/-/mpv/141145>. Acesso em: 28 de jun. 2020.

[13] MORAN, José Manuel et al. Novas tecnologias e Mediação Pedagógica. 6 ed. Campinas: Papirus, 2000.

[14] MORIN, Edgar. Os sete saberes Necessários à Educação do Futuro. Brasília: Cortez e Unesco, 2000.

[15] PORTARIA Normativa № 11, de 20 de junho de $2017\left(^{*}\right)$. Normas para o credenciamento de Instituições e a oferta de Cursos Superiores a Distância. portal.mec.gov.br. 2017. Disponível em: <http://portal.mec.gov.br/docman/maio-2017-pdf/66431-portaria-normativa-11-pdf/file>. Acesso em: 09 de maio de 2020.

[16] PROPOSTA altera comemoração de feriados nacionais conforme o dia da semana. Agência Câmara de Notícias. 2020. Disponível em: <https://www.camara.leg.br/noticias/673508-proposta-altera-comemoracao-de-feriadosnacionais-conforme-o-dia-da-semana>. Acesso em: 28 de jun. de 2020.

[17] RESOLUÇÃo CNE/CES 3/2007. Diário Oficial da União, Brasília, 3 de julho de 2007, Seção 1, p. 56. portal.mec.gov.br. 2007. Disponível em: <http://portal.mec.gov.br/cne/arquivos/pdf/rces003_07.pdf >. Acesso em: 09 de maio de 2020.

[18] RETOMADA das aulas para 8 de setembro. Governo do Estado de São Paulo. Secretaria de Educação. 2020. Disponível em: <https://www.educacao.sp.gov.br/coronavirus/governo-de-sp-anuncia-retomada-das-aulas-para-8de-setembro/>. Acesso em: 28 de jun.de 2020.

[19] SILVIA, Andreza Regina Lopes. Demandas para a educação a distância no Brasil no século XXI. Ponta Grossa PR: Editora Atenas, 2017.

[20] SPINK, Mary Jane P. A ética na pesquisa social: da perspectiva prescritiva à interanimação dialógica. Revista Semestral da Faculdade de Psicologia da PUCRS. 2000, v. 31, n. 1, jan./jul., p. 7-22. 


\section{Capítulo 21}

(Re)significação da prática docente na pandemia por Covid-19: Ensino remoto emergencial, novos sentidos, novas perspectivas

\section{Suzyneide Soares Dantas Valcácio}

Resumo: A pandemia por Covid-19 impôs o isolamento social impedindo professores e alunos de irem às escolas. 0 ensino remoto emergencial surge como a opção. Esse estudo tem por objetivo promover discussões sobre o processo de (re)significação da prática docente com o ensino remoto emergencial imposto pela pandemia por Covid-19, identificando as competências, habilidades, saberes que envolvem a profissão docente nesse momento de mudanças. Utilizou-se a pesquisa bibliográfica de cunho exploratório baseada nas contribuições de Freire(2006), Shön(2000), Perrenoud(2000), Imbernón(2010), Tardif(2002), Candau e Lelis(2000) e Moreira (2011). Shön(2000) evidencia a necessidade de uma sensibilidade artística, um saber-fazer sólido, teórico e prático, inteligente e criativo que permita ao professor agir em contextos instáveis, indeterminados e complexos. Perrenoud(2000) destaca o acesso e uso das TICs que envolve operações mentais, aprendizagens, construção de competências. Freire (1996) postula que ensinar exige reflexão crítica sobre a prática, implicante do pensar certo, movimento dinâmico, dialético entre o fazer e o pensar sobre o fazer. Candau e Lelis(2000), Tarfit(2002), Moreira(2011) e Imbernón(2010) consideram que a reflexão crítica com disponibilidade a mudança, é o momento fundamental no processo de formação continuada dos professores. Enfim, as discussões propostas indicaram que o processo de (re)significação da prática docente requer a (re)construção de competências a partir de uma nova maneira de sentir, pensar e agir dos professores diante dos desafios que os possibilitam a um novo fazer-pedagógico.

Palavras-chave: Prática Docente, Pandemia, Covid-19. 


\section{INTRODUÇÃO}

A doença de COVID-19 (Coronavirus Diseade 2019) foi identificada em dezembro de 2019. Trata-se de uma infecção respiratória provocada pelo Coronavírus da Síndrome Respiratória Aguda Grave 2 (SARS-CoV-2). (SCHUCHMANN et al, 2020).

Em março de 2020, a Covid-19 foi declarada pela Organização Mundial de Saúde (OMS) como uma pandemia (SCHMIDT et al, 2020). Doença viral com alto grau de transmissão e propagação a nível mundial. Em virtude dessa considerável propagação, nesse mesmo mês, as autoridades governamentais adotaram o isolamento social como forma de reduzir o ritmo de progressão da doença.

Nesse cenário, sob a orientação e normatização do Ministério da Educação (MEC), as instituições de ensino suspenderam suas atividades escolares presenciais e, estudantes e professores, transitaram de forma imediata, abrupta, do ensino presencial para o ensino remoto emergencial (ERE). Mudança na percepção do tempo e do espaço da prática docente. Os profissionais da educação se viram obrigados a se adaptar adequando a sua prática profissional a uma nova maneira de ensinar e de aprender. Os professores se viram diante dos limites e possibilidades do ensino remoto emergencial (ERE) que exigia novos sentidos e novas perspectivas no processo educativo.

Diante do exposto, o objetivo desse estudo foi discutir sobre o processo de (re)significação da prática profissional docente provocada pela pandemia por Covid-19 que conduziu uma nova forma de sentir, pensar e agir no cenário da Educação. Para tanto, utilizou-se da seguinte questão norteadora: "Que competências, habilidades, saberes que envolvem a profissão docente, precisam ser evidenciados no contexto do ensino remoto emergencial (ERE) imposto pela pandemia por Covid-19?"

Dessa forma, considerando o objetivo proposto, esse estudo se baseou nas contribuições de Freire(2006), Shön(2000), Perrenoud(2000), Imbernón(2010), Tardif(2002), Candau e Lelis(2000) e Moreira(2011) .

Freire (2006) enfatiza sobre os saberes necessários à prática educativa. Para responder à questão norteadora dessa pesquisa recorreu-se a seguinte premissa freireina, "ensinar exige reflexão crítica sobre a prática educativa"(FREIRE, 2006, p.38). Ensinar exige uma prática docente crítica, implicante do pensar certo, envolve o movimento dinâmico, dialético, entre o fazer e o pensar sobre o fazer. Por isso, a formação permanente dos professores, o momento fundamental é o de reflexão crítica sobre a prática com a disponibilidade para mudar.(FREIRE, 2006)

Shön(2000) evidencia em seus estudos que os professores necessitam de uma sensibilidade artística, um saber-fazer sólido, teórico e prático, inteligente e criativo que permite aos profissional agir em contextos instáveis, indeterminados e complexos. Exige uma reflexão e uma atenção dialogante com a própria realidade que lhe fala.

Perrenoud(2000) propõe uma prática reflexiva, profissionalizante, trabalho em equipe e por projetos, autonomia e responsabilidade crescentes, pedagogias diferenciadas, centralização sobre dispositivos e sobre as situações de aprendizagem, sensibilização à relação com o saber.

Imbernón(2010) enfoca que, a profissão docente deve abandonar a concepção predominantemente no século XIX de mera transmissão do conhecimento acadêmico, de onde de fato provém, e que se tornou inteiramente obsoleta para a educação de hoje, numa sociedade democrática: plural, participativa, solidária e integradora.

Tardif(2002) por sua vez, questiona sobre quais saberes que servem de base ao ofício de professor. Noutras palavras, quais são os conhecimentos, o saber-fazer, as competências e as habilidades que os professores mobilizam diariamente, a fim de realizar concretamente as suas diversas tarefas. E acrescenta, qual a natureza dos saberes docentes: saberes "eruditos", codificados; saberes da ação, de habilidades?

Candau e Lelis(2000) discutem sobre a relação teoria-prática na formação docente. Um dos problemas que mais fortemente emerge da análise da problemática da formação dos profissionais de educação. Certamente essa questão não é nova e, de fato, tem estado presente ao longo da história do pensamento humano e, de modo especial, na prática docente.

Moreira (2011) analisa criteriosamente os limites e possibilidades da formação docente, levantando questões como, que tipo de professor se pretende formar atrelados a que tipo de práticas pedagógicas. Considerar os professores como intelectuais, também implica em incitá-los a analisar a função social que desempenham, bem como a examinar que tradições e condições que os têm impedido exercitar uma prática transformadora mais efetiva. 
Enfim, as discussões e análises construídas a partir dos referenciais teóricos-metodológicos abordados que serviram de aportes para essa pesquisa, evidenciaram que, o processo de (re)significação da prática docente provocado pela pandemia por Covid-19, requer mudanças estruturais, organizacionais, profissionais e pessoais dos professores, os envolvendo enquanto sujeitos, interferindo de forma significativa em sua maneira de sentir, pensar e agir, dando novos sentidos, novas perspectivas, nova forma de pensar o fazerpedagógico.

\section{METODOLOGIA}

Utilizou-se como metodologia de estudo, a pesquisa bibliográfica de cunho exploratório. Marconi e Lakatos (2000), Severino (2006) e Gil (2006) enfatizam que a esse tipo de pesquisa de levantamento de dados oferece meios para definir, resolver, não somente problemas já conhecidos, como também explorar novas áreas onde os problemas não se cristalizaram suficientemente.

Dessa forma, a pesquisa bibliográfica não é mera repetição do que já foi dito ou escrito sobre o assunto, mas propicia a investigação de um tema sob novo enfoque ou abordagem, chegando a conclusões inovadoras.

\section{RESULTADOS E DISCUSSÃO}

A pandemia por Covid-19 impôs o isolamento social, provocando alterações de ordem estrutural e organizacional em todas as áreas profissionais, inclusive na profissão docente. Nessa, o ensino remoto emergencial (ERE) mediado pelas tecnologias de informação e comunicação(TICs) foi a única opção nesse cenário de crise que impuseram mudanças na maneira de ensinar e aprender.

Holges e colaboradores (2020) definem Ensino Remoto Emergencial (ERE) como uma mudança temporária da entrega de instruções para um modo de entrega alternativo devido a circunstâncias de crise. Envolve o uso de soluções de ensino totalmente remotas para instrução ou educação que, de outra forma, seriam ministradas presencialmente ou como cursos combinados ou híbridos e que retornarão a esse formato assim que a crise ou emergência tiver diminuído.

0 ensino remoto é emergencial pelo fato professores e alunos estão impedidos por Decreto do Ministério da Educação (MEC) e Secretariais Estaduais de Educação de frequentarem escolas e Instituições de Ensino Superior, evitando a disseminação do vírus, seguindo os planos de contingências orientados pelo Ministério da Saúde. É emergencial porque do dia para noite, o planejamento pedagógico, pensado, debatido e estudado para o ano letivo de 2020 teve que ser alterado, e substituído de forma abrupta.

Diante do exposto, esse estudo se propôs a discutir sobre o processo de (re)significação da prática profissional docente provocada pela pandemia por Covid-19 conduzindo uma nova forma de sentir, pensar e agir no exercício da profissão. Tratando, utilizou-se de referenciais teóricos-metodológicos pertinentes, a partir da seguinte questão norteadora; "Que competências, habilidades, saberes que envolvem a profissão docente precisam ser evidenciados no contexto do ensino remoto emergencial (ERE) imposto pela pandemia por Covid-19?"

Para tecer caminhos em busca de respostas a esse questionamento, recorreu-se as contribuições de Freire(2006), Shön(2000), Perrenoud(2000), Imbernón(2010), Tardif(2002), Candau e Lelis(2000) e Moreira (2011).

Freire(2006) destaca saberes necessários à prática educativa. Para discutir a questão norteadora desse estudo destacamos a premissa: "ensinar exige reflexão crítica sobre a prática educativa"(FREIRE, 2006, p.38). Essa premissa enfatiza que é necessário à reflexão crítica para que o professor perceba as razões de ser para se tornar capaz de mudar. Nesse sentido, no ensino remoto emergencial imposto pela pandemia por Covid-19, o professor precisa a cada aula remota avaliar de forma crítica-reflexiva, saber o que mudar em sua prática pedagógica para melhor contribuir no desenvolvimento dos seus alunos. Essa é uma exigência fundamental na perspectiva freiriana.

Nessa mesma linha de exigência para a prática docente, Shön (2000) propõe uma educação reflexiva para o profissional docente adotando um novo design para o ensino e a aprendizagem. As ideias de Shön(2000) contribuem nesse cenário atual do ensino remoto em que requer do professor uma formação profissional prática a partir das novas tecnologias da informação e comunicação(TICs) para a condução ativa do conhecimento na ação, ou seja, aprender a fazer fazendo. 
Shön(2000) utiliza o termo talento artístico profissional para referir a competência que os profissionais da educação tem que demonstrar em certas situações, que são únicas, incertas e conflituosas. Esse pesquisador enfatiza que essa competência não depende da capacidade de descrever o que sabemos fazer ou mesmo considerar, conscientemente, mas, o conhecimento que a ação docente revela no momento da aula.

A performance conhecer-na-ação (SHÖN, 2000) é essencial à prática docente no cenário das aulas remotas emergenciais impostas pela Covid-19 a partir do momento que tudo é inédito nesse cenário. Consiste no procedimento ou a maneira especial, sem antecedentes especiais. Tal processo envolve a reflexão-naação(SHÖN, 2020) promovendo reconhecimento, apreciação e ajustes necessários à prática docente. 0 professor aprende a executar atividades complexas em que as ações são sempre construções testadas no presente-da-ação(SHÖN, 2000), ou seja, no momento, no contexto.

Perrenoud(2000) por sua vez chama a atenção das competências profissionais para ensinar enfatizando que, elas surgem com a crise na educação em que se decide na incerteza e agem na urgência. Esclarece que as competências profissionais estão sempre mudando a partir da complexidade do ato de ensinar, por isso, as competências representam mais um horizonte do que um conhecimento consolidado. Portanto, descreve um futuro possível e, desejável da profissão.

0 trabalho aprofundado sobre as competências consiste em primeiramente, relacionar cada uma delas a cum conjunto delimitado de problemas e tarefas; em seguida, em arrolar os recursos cognitivos (saberes, técnicas, savoir-faire, atitudes, competências mais específicas) mobilizados pela competência em questão. (PERRENOUD, 2000, p.17)

Nesse sentido, as competências necessárias a prática docente no ensino remoto emergencial serão construídas a partir da ação docente em que cada elemento de um referencial de competência pode remeter a práticas antes seletivas e conservadoras ou a práticas democráticas e renovadoras. Dessa forma, indo além das abstrações, saber-se-á de que pedagogia e de que escola se fala. A partir dessas considerações, os conhecimentos teóricos e metodológicos que mobilizam as competências serão designados.

A noção de competência defendida por Perrenoud (2000) designará uma capacidade mobilizadora de diversos recursos cognitivos para enfrentar um tipo de situação inusitada, no caso em questão, a situação do ensino remoto emergencial imposto pela pandemia do Covid-19. Para Perrenoud (2000, p.18), "Essa mobilização só pertinente em situação, sendo cada situação singular, mesmo que se possa tratá-la em analogia com outras, já encontradas". E conclui: "as competências profissionais constroem-se, em formação mas também, ao sabor da navegação diária de um professor, de uma situação de trabalho à outra. (PERRENOUD, 2000, p.19).

Imbernón (2010) vem reforçar as ideais de Freire(2006), Shön(2000) e Perrenoud(2000) em que a formação docente e profissional deve ocorrer para a mudança e a incerteza. Justamente o que a situação do ensino remoto emergencial imposto pela pandemia por Covid-19 evidência.

A profissão docente comporta um conhecimento pedagógico específico, um compromisso ético e moral e a necessidade de dividir a responsabilidade com outros agentes sociais, já que exerce influência sobre outros seres humanos e, portanto, não pode nem deve ser uma profissão meramente técnica de "especialistas infalíveis" que transmitem unicamente conhecimentos acadêmicos. (IMBERNÓN, 2010, p.35)

Imbernón(2010) aborda que diversos pesquisadores procuram analisar o tipo de conhecimentos profissionais que um professor deveria ter. Todos concordam com a necessidade de um conhecimento polivalente que compreenda diferentes âmbitos. Seja como for, há especificidade da profissão está no conhecimento pedagógico. Esse conhecimento pedagógico está unido a ação e, portanto, é um conhecimento prático, que é o que diferencia e estabelece a profissão e que precisa de um processo concreto de profissionalização.

Concordando com as ideias de Shön (2000), Tardif(2002), Imbernón (2010) argumenta que o conhecimento pedagógico profissional é tácito e intuitivo elaborado nas "destilações retrospectivas da experiência". o conhecimento proposicional prévio, o contexto, a experiência e a reflexão em e sobre a prática levarão à precipitação do conhecimento profissional especializado. 
Candau e Lelis(2000) juntamente com Moreira (2011), analisam os limites e possibilidades da formação docente. Para esses pesquisadores, os professores são em essência, intelectuais transformadores. Dentre outros aspectos, também significa desenvolver, no futuro profissional, a capacidade de utilizar procedimentos e criar alternativas que possibilitem contribuir para o melhor desenvolvimento de seus alunos e para seu engajamento na luta pela qualidade do ensino.

Nesta alternativa, proporcionar uma (re)significação da prática docente significa assumir os limites e possibilidades da ação educativa em seu fazer pedagógico, o qual abrange "o que ensinar" e "como ensinar", articulado ao "para quem" e "para quer, expressando a unidade entre os conteúdos teóricos e instrumentais, sob diferentes configurações, sem que se perca a visão de totalidade da prática pedagógica e da formação como forma de eliminar distorções decorrentes da priorização de um sob o outro.

Enfim, os estudos teóricos realizados durante essa pesquisa promoveram discussões relevantes sobre competências, habilidades, saberes necessários a prática docente. Os limites e as possibilidades identificadas pelos autores pesquisados, indicam que é possível desenvolver uma "práxis" criadora vinculando o pensar e o agir na perspectiva da unicidade, da inventividade, da irrepetibilidade, em momentos de crise, de mudanças em que se encontra a educação brasileira.

\section{CONSIDERAÇÕES FINAIS}

A pesquisa bibliográfica como referencial teórico pertinentes ora realizada, promoveu discussões valorosas sobre o processo de (re)significação da prática docente com o ensino remoto emergencial(ERE) imposto pela pandemia por Covid-19.

Recorrendo a referenciais teóricos como Freire(2006), Shön(2000), Perrenoud(2000), Imbernón(2010), Tardif(2002), Candau e Lelis(2000) e Moreira (2011) para discutir sobre a prática docente em situação de pandemia por Covid-19, a partir da questão norteadora: "Que competências, habilidades, saberes que envolvem a profissão docente precisam ser evidenciados no contexto do ensino remoto emergencial(ERE) imposto pela pandemia por Covid-19", concluiu-se que:

- As competências, habilidades e saberes que envolvem a profissão docente constitui e reconstitui constantemente durante a vida profissional em sua relação teoria e prática;

- As competências, habilidades e saberes que envolvem a profissão docente se legitimam na prática, reunindo características específicas como complexidade e observabilidade;

- Nas próximas décadas, a profissão docente deverá desenvolver-se em uma sociedade em mudança com um alto nível tecnológico e um vertiginoso avanço do conhecimento.

O ensino remoto emergencial (ERE) provocou um (re)pensar sobre a prática pedagógica docente. Uma prática que experimenta, que aprende, que inova, que tenta, que arrisca, sempre buscando o melhor para o ator mais importante deste processo e a razão das escolas existirem, o aluno e seu aprendizado.

Enfim, verificou-se que, o processo de (re)significação da prática docente imposta pela pandemia por Covid19 , requer mudanças estruturais e organizacionais dos professores na sua maneira de sentir, pensar e agir dando novos sentidos, novas perspectivas ao fazer-pedagógico em um processo contínuo de ação-reflexãoação(SHÖN, 2000).

\section{REFERÊNCIAS}

[1] CANDAU, V.M; LELIS, I.A. A relação teoria-prática na formação do educador. In: CANDAU,V.M. (org.). Rumo a uma nova didática. 9.ed. São Paulo: Vozes, p.56-72, 2000.

[2] FREIRE, P. Pedagogia da Autonomia. 34.ed. São Paulo: Paz e Terra, 2006.

[3] HODGES, C. et al. The difference Between Emergency Remote Teaching and Online Learning. Educause Review. 2020.https://er.educause.edu/articles/2020/3/the-difference-between-emergency-remote-teaching-and-onlinelearning. Acesso em 10 de agost.2020.

[4] IMBERNÓN, F. Formação docente e profissional: forma-se para a mudança e a incerteza. 8.ed. São Paulo: Cortez, 2010.

[5] MINISTÉRIO DA SAÚDE(Brasil). Portaria no. 454, de 20 de março de 2020. Declara, em todo o território nacional, o estado de transmissão comunitária do coronavírus (Covid-19). Diário Oficial da União. Brasília: Autor. http://w.in.gov.br/en/web/dou/-/portaria-n-454-de-20-de-março-de-2020-249091587 Acesso em 15 de agost.2020. 
[6] MOREIRA, A.F.B. A formação de professores e o aluno das camadas populares: subsídios de debate. In: ALVES, N. (org.) Formação de professores:pensar e fazer. 11.ed. São Paulo: Cortez, p.39-56, 2011.(Coleção questões de nossa época,; v.30).

[7] PERRENOUD, P. Dez novas competências para Ensinar. Porto Alegre: Artes Médicas Sul, 2000.

[8] SCHMIDT, B., CREPALDI, M. A., BOLZE, S. D. A., NEIVA, Silva, L., \& DEMENECH, L. M. (2020). Impactos na saúde mental e intervenções psicológicas diante da pandemia do novo Coronavírus (COVID-19). SciELO Preprints,1(1),126.https://doi.org/10.1590/SCIELOPREPRINTS.58. Acesso em 12 de agosto de 2020.

[9] SCHÖEN, D.A. Educando o Profissional Reflexivo: um novo design para o ensino e a aprendizagem. Porto Alegre: Artmed, 2000.

[10] SCHUCHMANN, A. Z., SCHNORRENBERGEr, B. L., CHIQUETTI, M. E., GAIKI, R. S., RAIMANN, B. W., MAEYAMA, M. A. (2020). Isolamento social vertical X Isolamento social horizontal: os dilemas sanitários e sociais no enfrentamento da pandemia por Covid-19. Brazilian Journal of Health Review, 3(2), 3556-3576. https://doi.org/10.34119/bjhrv3n2185.Acesso em 12 de agosto de 2020.

[11] TARDIF, Maurice. Saberes Docentes e Formação Profissional. Petrópolis: Vozes, 2002. 


\section{Capítulo 22}

\section{A equação que Einstein sonhou: Equação de Tudo}

\section{André Luis Bonaventura}

\section{Barbara Alves Nascimento Marques}

Resumo: A unificação entre física quântica (FQ) e teoria da relatividade geral (TRG) permitirá descrever todas as forças do Universo em uma só equação. Muitas propostas foram apresentadas, tais como: a teoria das cordas e a teoria da grande unificação (TGU). O próprio autor da TRG, Albert Einstein, dedicou grande parte da vida em busca da unificação e de uma única equação capaz de descrever todo o Universo. A pergunta fundamental é: será possível obter tal equação? A resposta é sim e neste artigo apresentamos as hipóteses físicas e propomos uma equação que unifica todas as interações fundamentais da natureza. Para tanto, tangenciamos conceitos fundamentais de TRG, FQ e cosmologia. O resultado é uma equação tensorial que relaciona os tensores energia-partícula-momento dos campos fundamentais (gravitacional, forte, fraco, Higgs e eletromagnético) com os tensores das geometrias de cada campo (gravitacional, forte, fraco, Higgs e eletromagnético), tendo como arquetípico a TRG e a teoria quântica de campos (TQC).

Palavras-chave: Relatividade geral, teoria da unificação, quântica, tensor. 


\section{INTRODUÇÃO}

A ciência do século XX foi marcada por grandes avanços e teorias tais como: a FQ e a TRG. Ambas foram e são constantemente comprovadas por inúmeros experimentos e aplicações tecnológicas (WU, B. et al., 2010). Contudo, uma teoria que as unifica ainda é procurada, afinal elas representam a mesma natureza.

A FQ teve início com Max Planck resolvendo o problema da radiação do corpo negro. Outros problemas relevantes foram resolvidos por meio de tal teoria, tais como o efeito fotoelétrico, modelos atômicos, dualidade das partículas, equação de onda e o princípio da incerteza de Heisenberg, que é descrito na equação 1 (EISBERG; RESNICK, 1979).

$$
\Delta E \Delta t \geq \frac{h}{4 \pi}
$$

Já a TRG apresenta uma nova explicação para a força gravitacional newtoniana. Albert Einstein mostrou que a gravidade é uma deformação da geometria $(\mathrm{G} \mu \nu)$ do espaço-tempo em relação ao tensor energia-momento $(\mathrm{T} \mu \nu)$. Essa relação se dá pela equação de campo de Einstein descrita na equação 2 (RYDEN, 2016).

$$
G_{\mu \nu}=k T_{\mu \nu}
$$

O lado esquerdo da equação 2 , termo G $\mu \nu$, é responsável pela geometria e pode ser reescrito como a soma do tensor de curvatura de Ricci, tensor métrico, tensor curvatura escalar e da constante cosmológica. Já o lado direito da equação 2 representa o tensor momento-energia, ou seja, como a energia ou massa são

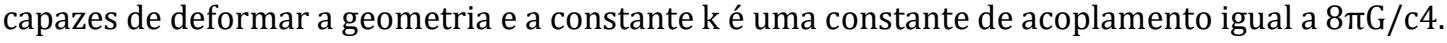

Ambas as teorias, quântica e relativística, são usadas na cosmologia. 0 modelo cosmológico mais aceito é o $\Lambda$-CDM (lambda - matéria escura fria, em inglês "Lambda - Cold Dark Matter"). Nele se contempla a evolução do Universo a partir de uma singularidade ("Big Bang"). De acordo com o modelo $\Lambda$-CDM, as forças fundamentais (gravitacional, forte, fraca e eletromagnética) estavam acopladas no Universo primordial. Porém, após o Big Bang houve o desacoplamento de tais forças. Após o Big Bang primeira força a desacoplar foi a da gravidade $(t \approx 1 \times 10-43 \mathrm{~s})$ seguida da força forte $(t \approx 1 \times 10-35 \mathrm{~s})$, força fraca $(\mathrm{t} \approx 1 \times 10-12 \mathrm{~s})$ e da força eletromagnética $(\mathrm{t} \approx 1 \times 10-6 \mathrm{~s})$. Outro fato a ser destacado é que o Universo primordial sofreu uma grande expansão entre o intervalo $1 \times 10-37 \mathrm{~s}$ à $1 \times 10-35 \mathrm{~s}$, aumentando o raio do Universo aproximadamente $1 \times 10+30$ vezes (RYDEN, 2016).

Assim, para a cosmologia e para TRG o Universo é preenchido pelo espaço-tempo e tudo o que há nele. 0 espaço-tempo é formado por 4 dimensões ( $\mathrm{x}, \mathrm{y}, \mathrm{z}$ e t). É comum ilustrar tal espaço-tempo como sendo conjunto consecutivo de células de 4 dimensões, que juntas formam o tecido espaço-tempo flexível de geometria $\mathrm{G} \mu \nu$. Importante destacar que para TRG, quando $\mathrm{T} \mu \nu=0$ (ausência de massa ou energia) o tensor da geometria (G $\mathrm{Gv}$ ) é nulo, e este fato implica na geometria plana tal como é esperado no meio intergaláctico (larga escala: acima de $100 \mathrm{Mpc}$ ) (RYDEN, 2016).

Já no contexto quântico, a natureza também é descrita pela teoria quântica de campo (TQC), no qual um campo é descrito por pacotes (células) de energia virtual de partículas de força (bóson) (KRONFELD, 2018). Arquétipos da TQC são a cromodinâmica quântica, a eletrofraca e a eletrodinâmica quântica (TEQ) (QINGDONG; WILCZEK, 2019).

Utilizando todos esses conceitos, é possível propor uma teoria que unifica todas as interações da natureza em uma só equação geral, tendo como elo a cosmologia conforme será apresentado na seção de resultados e discussões.

\section{METODOLOGIA}

Os métodos utilizados neste trabalho constituíram em relacionar os conceitos e equações da física quântica, relativísticas e cosmológicas, por meio de uma análise dimensional, conceitual e dados reportados na literatura.

\section{RESULTADOS E DISCUSSÕES}


O 1ำ resultado apresentado é a interpretação de que a estrutura do Universo é formada por 5 campos fundamentais conectados entre si pela dimensão temporal. Estes campos são: gravitacional-tempo (G-t, sinônimo de espaço-tempo), forte-tempo (F-t), fraco-tempo (Fr-t), eletromagnético-tempo (EM-t) e Higgstempo $(\mathrm{H}-\mathrm{t})$. Cada campo possui suas dimensões próprias. Por exemplo, o G-t possui as dimensões espaciais $\mathrm{x}, \mathrm{y}, \mathrm{z}$ e o tempo assim como o EM-t possui as dimensões elétrica (E), magnética (B) e o tempo. Assim, os demais campos também apresentam suas próprias dimensões e, para fins didáticos, vamos atribuir os mesmos nomes das partículas bosônicas, sendo assim, campo F-t: glúons (g) e tempo, Fr-t: W+, W-, Z0 e tempo e H-t: Higgs $(\mathrm{H})$ e tempo. A soma das dimensões que formam a estrutura do Universo é igual a $11(\mathrm{x}$, $y, z, E, B, g, W+, W-, Z 0, H, t)$, como previa a teoria das cordas.

Uma aplicação direta deste resultado é que uma partícula do modelo padrão, tal como o elétron, pode ser escrito pela soma de 6 dimensões (x, y, z: pelo fato do elétron ocupar lugar no espaço, por E e B características intrínsecas ao elétron, $\mathrm{H}$ pelo fato do elétron possuir massa e a dimensão temporal pelo fato de o elétron ser dual, logo, pode ser descrito por uma onda). A soma das dimensões implica nas sobreposições de geometrias que formam a estrutura do Universo. A analogia vale para demais partículas fundamentais e essa teoria está de acordo com a conservação das grandezas fundamentais (energia, carga, números leptônicos).

O 2º resultado desse trabalho é a interpretação da equação 1 como sendo uma célula com densidade de energia temporal, A(B). Assim, a interpretação gráfica das células que formam o espaço-tempo da TRG ou mesmo dos pacotes de energia da TQC é a própria definição de A(B). Cada campo possui um A(B) típico e isto os distingue fundamentalmente uns dos outros. Este fato está implícito na evolução cosmológica do Universo. No Big Bang todas as forças estavam unificadas, logo A(B) era a mesma para todos os campos. Contudo, houve o desacoplamento das forças em instantes diferentes, o que fez cada campo ter sua própria A(B). Um fato de extrema relevância, de acordo com o modelo $\Lambda$-CDM, é que no intervalo em que houve a grande expansão primordial (entre 1x10-37 s à 1x10-35 s) apenas a força gravitacional estava desacoplada, logo, as dimensões espaciais do G-t expandiu 1x10+30 vezes em relação às demais dimensões e campos, fazendo com que a $\mathrm{A}(\mathrm{B})$ gravitacional diluíssem significativamente em relação aos demais campos. Posteriormente as demais forças (e campos) foram desacopladas em momentos diferentes e se expandiram até o momento presente. Assim, os valores aproximados de A(B) para cada campo fundamental da natureza são: 6,626x10-34 Js, 1x10-32 Js, 1x10-39 Js e 1x10-70 Js respectivamente para EM-t, F-t, Fr-t e G-t. Essas diferenças entre $A(B)$ de cada campo têm implicações diretas na física, tais como: diferenças nas intensidades relativas das forças fundamentais ou mesmo a necessidade de uma grande massa no G-t para que efeitos na gravidade tornam-se perceptíveis.

$03^{\circ}$ resultado é a sutil correção da equação 2 em relação a equação 1 . De acordo com a equação 1, a energia não pode ser nula, pois se fosse, violaria o princípio da incerteza de Heisenberg que possui um valor mínimo. Portanto, o tensor energia-momento T $\mu \nu$ nunca será nulo, logo, o tensor da geometria G $\mu \nu$ nunca será totalmente plano como era previsto no meio intergaláctico, por exemplo. Essa correção implica que sempre haverá uma energia residual de intensidade $\approx 1$ x10-70 J por unidade de tempo no G-t. Essa energia residual do vácuo é igual a energia do vácuo quântico prevista pela TQC, e que dá origem à espuma quântica ou mesmo as partículas virtuais de força (bóson virtual) para o espaço-tempo. Sendo assim, no vácuo quântico onde $\mathrm{T} \mu \nu \approx \Delta \mathrm{E}(\Delta \mathrm{E}$ a devido a presença de $\mathrm{A}(\mathrm{B}))$, a TRG converge com as previsões da TQC na qual prevê que existe a espuma quântica.

O $4^{\text {o }}$ resultado apresentado é a equação de campo para EM-t (equação 3) no qual relaciona o tensor eletromagnético (Tab) e a geometria formada pelas dimensões elétrica-magnética-tempo que são entrelaçadas ortogonalmente. Essa teoria para o EM-t é um arquétipo para TRG, pois a natureza repete padrões. A presença do sinal \pm implica que a célula A(B) do EM-t pode se deformar para dentro (sinônimo de implodir, convergindo para o centro) ou para fora (sinônimo de estufar, divergindo para fora), e este fato ocorre porque na natureza existem partículas elétricas positivas e negativas assim como polo sul e norte (REITZ; MILFORD; CHRISTY, 1988). Já o termo c1 é uma constante de acoplamento entre a geometria e o tensor que causou a deformação na geometria.

$$
C_{a b}= \pm c_{1} T_{a b}
$$

0 resultado desta equação, equação 3, implica que a interação à distância entre duas ou mais partículas elétricas não é devido a força elétrica coulombiana, (lei de Coulomb) e sim devido a deformação da 
geometria Cab por consequência do tensor Tab. Este resultado também é um arquétipo da TRG no qual a força gravitacional de Newton é substituída pela deformação do espaço-tempo.

A equação 3 é fácil de ser comprovada em um simples experimento de física básica, isto é, em uma cuba eletrolítica. Neste experimento um eletrodo é carregado eletricamente e com auxílio de limalhas de ferro pode-se analisar as deformações nas dimensões elétricas. Aqui é importante salientar que a presença da carga elétrica não distorce a geometria G $\mu \nu$ (não altera a gravidade) e sim distorce a geometria Cab. Portanto, o que observamos é a sobreposição das geometrias (EM-t e G-t), pois ambas as geometrias estão conectadas pela dimensão temporal que é comum entre os campos, então, é por isso que as limalhas de ferro podem se mover no espaço do G-t mesmo não alterando G $\mu \nu$.

Até agora, tanto a interação eletromagnética quanto a gravitacional, pôde ser relacionada com campos e geometrias tensoriais. Pelo fato de a natureza repetir padrões e pelos avanços da TQC, as demais interações fundamentais (fraca, forte e o campo de Higgs) também podem e devem ser descritas por geometrias e tensores. Sendo assim, o $5^{\circ}$ resultado, é descrito como a equação que Einstein sonhou, e é apresentado agora. De acordo com o $1^{\circ}$ resultado, a estrutura do Universo é a superposição de todos os campos fundamentais da natureza. Também de acordo com o $3^{\circ}$ resultado, mesmo na ausência de partícula ou massa sempre haverá uma energia residual no vácuo para cada campo. Portanto, devido a esses resultados qualquer ponto do Universo pode ser descrito pela soma tensorial de cada campo fundamental, conforme apresentado na equação 4. Na equação 4 o lado esquerdo representa a geometria de cada campo (Cab, Dcd, Eef, Fgh, G $\mu \nu$, respectivamente para as geometria dos campos EM-t, F-t, Fr-t, H-t e G-t) e o lado direito, o tensor energia-momento de cada campo (Tab, Tcd, Tef, Tgh, T $\mu v$, respectivamente para os tensores dos

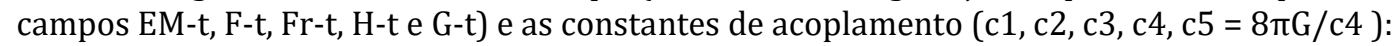

$$
C_{a b}+D_{c d}+E_{e f}+G_{\mu \nu}= \pm c_{1} T_{a b}+c_{2} T_{c d}+c_{3} T_{e f}+c_{4} T_{g h}+c_{5} T_{\mu \nu}
$$

A equação acima, equação 4, revela que as forças fundamentais da natureza (gravitacional, forte, fraca e eletromagnética) que classicamente são caracterizadas por forças capazes de agir à distâncias, na verdade são deformações das próprias geometrias que formam a estrutura do Universo (assim como foi apresentado na equação 2 e 3). Este fato une o mundo quântico com o macro/cosmo como é exemplificado a seguir.

Um único átomo radioativo, por exemplo, possui todas as geometrias da equação 4 deformadas localmente. Ao analisar as perturbações geométricas próximas ao átomo (escala atômica) a massa do átomo é capaz de deformar o campo G-t, porém devido a baixa densidade de energia A(B) do G-t e a pequena quantidade de massa do átomo a deformação em G $\mu \nu$ torna-se desprezível comparadas com as demais deformações dos outros campos fundamentais (porém a deformação em G $\mu \nu$ existe localmente!). Contudo, ao analisar em escala macroscópica ou mesmo cosmológicas (acima de $100 \mathrm{Mpc}$ ) as deformações locais nas geometrias (Cab, Dcd, Eef, Fgh) causada pelo átomo radioativo tornam-se desprezíveis, pois em larga escala tais geometria já se encontram no estado de A(B) residuais, ou seja, há distorções nas geometrias, porém no estado de menor energia (equação 1) devido a espuma quântica no vácuo de cada campo.

Um caso em que a A(B) do G-t torna-se relevante e competitiva com os demais campos é na proximidade de uma singularidade. A singularidade é a deformação acentuada do G-t, ou seja, das células que formam a geometria do espaço-tempo. Contudo, o tempo não pode ser nulo, então $\Delta \mathrm{E}$ do G-t aumenta (vide equação 1) e passa a competir com os demais A(B) dos demais campos (Cab, Dcd, Eef, Fgh). Como todos os campos estão conectados pela dimensão temporal, o tempo é afetado em todos os campos. Se há massa for suficiente para convergir até a singularidade o $\Delta \mathrm{E}$ do G-t aumentará tanto que será maior que os demais $\Delta \mathrm{E}$ dos $\mathrm{A}(\mathrm{B})$ dos outros campos. Neste caso, a $\Delta \mathrm{E}$ da célula do G-t torna-se maior que a $\Delta \mathrm{E}$ da célula do EM-t e por isso a luz não consegue sair, pois o $\Delta \mathrm{E}$ do EM-t é menor e a luz fica acoplada na singularidade, como é observado no buraco negro, por exemplo.

Outros argumentos que fomentam o trabalho apresentado aqui são:

1) a velocidade da luz no vácuo diminui quando ela passa pela deformação da geometria Cab, isto é, devido a presença de um campo eletromagnético no vácuo (PELLE, B. et al., 2011). Este fato é similar a alteração da velocidade ou órbita de um corpo massivo quando o mesmo passa pela a deformação da geometria do G-t;

2) experimento recente indica que o tamanho do próton é menor do que previsto pela teoria quântica, este fato pode estar relacionado devido $A(B)$ do campo F-t ser levemente superior ao A(B) do EM-t, portanto sendo necessário recalcular o tamanho teórico do próton (ANTOGNINI, A. et al., 2013). 


\section{CONCLUSÃO}

De acordo com as hipóteses apresentadas neste artigo, a estrutura do Universo é formada por 5 campos fundamentais (gravitacional, forte, fraco, eletromagnético e Higgs) conectados pela dimensão temporal. No total o Universo é feito de 11 dimensões. Os campos podem ser interpretados pelo arquetípico da TRG, e possuem células com densidade de energia temporal $A(B)$ distintas, devido ao desacoplamento das forças fundamentais ocorridas em tempos distintos após o Big Bang. Cada campo pode ser descrito pela própria geometria e está relacionado com seu respectivo tensor energia-momento. Sendo assim, mesmo na ausência de uma partícula em um campo este campo existe e possui uma energia residual devido a A(B) característica de cada campo. A soma tensorial de todos os campos descreve uma única equação em que todas as interações da natureza se interagem, isto é, permitindo a unificação de todas as forças em uma só equação, como Albert Einstein sonhou.

\section{REFERÊNCIAS}

[1] ANTOGNINI, A. et al. Proton Structure from the Measurement of 2S-2P Transition Frequencies of Muonic Hydrogen. 339. Vol. Washington: Science, 2013.

[2] EISBERG, R., RESNICK, R. Física quância: átomo, moléculas, sólidos, núcleos e partículas. Rio de Janeiro: Campus, 1979 .

[3] KRONFELD, A. S. The Weight of the World Is Quantum Chromodynamics. 322. Vol. Washington: Science, 2018.

[4] PELLE, B. et al. Magnetoelectric directional nonreciprocity in molecular nitrogen gas. 106. Vol. New York: Physical Review Letters, 2011.

[5] QING-DONG, J.; WILCZEK, F. Chiral Casimir forces: Repulsive, enhanced, tunable. 99. Vol. New York: Physical Review B, 2019.

[6] REITZ, J. R.; MILFORD, F. J.; CHRISTY, R. W. Fundamentos da teoria eletromagnética. 3. ed. Rio de Janeiro: Campus, 1988.

[7] RYDEN, B. Introduction to Cosmology. 2. Ed. Cambridge: Cambridge University, 2016.

[8] WU, B. et al. Slow light on a chip via atomic quantum state control. New York: Nature Photonics, 2010. 


\section{Capítulo 23}

\section{Considerações sobre testes de normalidade utilizados pelo Software Gretl}

\section{Gérson dos Santos Nunes}

Viviane Leite Dias de Mattos

Andrea Cristina Konrath

Resumo: Na inferência estatística clássica, muitas vezes deseja-se que os dados analisados apresentem distribuição normal, para cumprir as suposições do modelo teórico utilizado. Para verificação desta propriedade são utilizados os chamados testes de normalidade, que possuem a função de averiguar se a distribuição de probabilidade associada a um conjunto de dados pode ser aproximada a uma distribuição normal. 0 presente estudo avaliou o desempenho dos quatro testes de normalidade existentes no software estatístico Gretl: teste de Jarque-Bera, teste de Doornik-Hansen, teste de Shapiro-Wilk e teste de Kolmogorv-Smirnov Lilliefors. Foram geradas amostras com 20, 50, 100 e 500 unidades amostrais oriundas de população normalmente distribuída e não normalmente distribuída. Constatou-se que todos os testes apresentaram bom desempenho para as amostras geradas com normalidade, o mesmo não acontecendo em amostras sem esta propriedade. Neste último caso, o teste de Shapiro-Wilk apresentou o melhor desempenho, principalmente em amostras menores. Destaca-se, entretanto que, para grandes amostras, todos os testes também apresentaram bom desempenho.

Palavras-chave: Testes de Normalidade; Teste Jarque-Bera; Teste Doornik-Hansen; Teste Shapiro-Wilk; Teste Kolmogorv-Simirnov Lilliefors; 


\section{INTRODUÇÃO}

Uma das mais importantes distribuições contínuas de probabilidade é a distribuição Normal. Além de descrever o padrão de comportamento de uma série de fenômenos, ela é de grande importância na estatística inferencial clássica. Esta distribuição influencia diretamente na qualidade e confiabilidade de resultados de algumas análises estatísticas desenvolvidas em pesquisas científicas, em que são adotados procedimentos em que a normalidade dos dados é uma exigência do modelo teórico utilizado. A não comprovação dessa suposição influencia diretamente na qualidade e confiabilidade da inferência estatística, podendo acarretar em resultados e conclusões incorretas.

Segundo Morettin (2011), no estudo das séries temporais, por exemplo, se uma série de dados for considerada normal ou gaussiana, seu comportamento poderá ser descrito por um modelo linear, como por exemplo um modelo ARMA. Sendo assim, os testes de normalidade são utilizados para verificar se a distribuição de probabilidade associada a um conjunto de dados pode ser considerada aproximada a uma distribuição normal.

Existem métodos gráficos que podem ser utilizados com esta finalidade, tais como: histograma, diagrama de caixas e gráfico de probabilidade normal, entre outros. Entretanto, métodos analíticos mais formais são mais confiáveis e não contém a subjetividade inerente a qualquer interpretação gráfica. Segundo Razali e Wah (2011), aproximadamente 40 testes de hipóteses já foram propostos para avaliar a normalidade de um conjunto de dados.

O software estatístico Gnu Regression, Econometricsand Times-Séries Library (Gretl) (Cottrell \& Lucchetti, 2018), proposto para ser utilizado principalmente em análises de séries temporais, pode realizar quatro diferentes testes afim de verificar a esta propriedade na série observada: o teste de Jarque-Bera, o teste de Doornik-Hansen, o teste Shapiro-Wilk e o teste de Kolmogorv-Smirnov Lilliefors.

Sendo assim, este texto apresenta os resultados preliminares de um estudo realizado com o objetivo, analisar o desempenho dos testes supra citados, desenvolvidos por meio do software estatístico Gretl. Este software foi selecionado não só por se livre, mas também por sua simplicidade operacional.

\section{CONSIDERAÇÕES SOBRE OS TESTES DE NORMALIDADE ANALISADOS}

Segundo Bueno (2011), o teste Jarque-Bera, proposto por Jarque e Bera (1987), testa a hipótese nula de que os dados seguem uma distribuição normal verificando se os coeficientes de assimetria e curtose da série estudada podem ser considerados iguais aos respectivos coeficientes de uma distribuição Normal. É importante notar que a rejeição da hipótese nula indica evidências de não normalidade, porém a não rejeição indica apenas que não foram encontradas evidências de que o terceiro e o quarto momentos da distribuição empírica coincidem com os da distribuição Normal. Este teste é conhecido por ter boas propriedades para verificar normalidade, apresentando, entretanto, grande taxa de ocorrência de erro do tipo I, que ocorre quando o teste não rejeita algo falso. Se os dados apresentam distribuição Normal, sua estatística de teste deste teste apresenta distribuição Qui-quadrado com dois graus de liberdade. A execução deste teste é fácil, clara e simples, sendo muito utilizado análises econométricas. Lucambio (2008) chama a atenção para o fato de que, este teste serve apenas para verificação da normalidade, o que considera uma limitação, pois outros podem avaliar a similaridade dos dados analisados com diversas distribuições.

Em concordância com Adkins (2009), o teste de Doornik-Hansen também utiliza a estatística Qui-quadrado para averiguar a veracidade na hipótese de normalidade, mas se trata de um modelo mais complexo que o utilizado pelo teste Jarque-Bera. Sua hipótese nula $\left(\mathrm{H}_{0}\right)$ considera que a amostra provem de uma distribuição normal, enquanto a hipótese alternativa $\left(\mathrm{H}_{1}\right)$ considera que a amostra não provem de uma distribuição normal, caracterizando-se por apresentar um bom desempenho em pequenas amostras.

O teste de Shapiro-Wilk também foi proposto para avaliar normalidade em Shapiro e Wilk (1965), inicialmente para amostras com menos de 50 observações, sendo bastante utilizado por suas propriedades. De acordo com Razali e Wah (2011), o teste passou por alguns ajustes para que pudesse ser útil em análises de amostras de maior tamanho, podendo ser utilizado em amostras de até 5000 observações.

De acordo com Abdi \& Molin (2007), o teste Kolmogorov-Simirnov Lilliefors é uma adaptação do teste de Kolmogorov-Smirnov (KS). Eles se caracterizam como testes não paramétricos que podem ser usados para comparar duas distribuições contínuas de probabilidade. 0 KS foi proposto por dois matemáticos em 1993 e posteriormente foi proposta a sua extensão: KS Lilliefours. A diferença básica entre eles está no fato de que o primeiro executa o teste a partir de média e desvio-padrão populacionais, que se supõe conhecidos, enquanto a adaptação Lilliefors usa a média e o desvio-padrão amostrais, calculados a partir do próprio 
conjunto de dados. A hipótese nula destes testes considera que os dados seguem a mesma distribuição, que pode ser a distribuição Normal, enquanto a hipótese alternativa indica que os dados não seguem a mesma distribuição. Este teste costuma ser mais sensível no centro da distribuição, existindo necessidade de especificar a distribuição considerada, que pode ser qualquer uma entre as distribuições contínuas.

\section{METODOLOGIA}

Para a realização do procedimento utilizado no presente estudo, foram criadas oito amostras, utilizando o gerador de números pseudo-aleatórios do software Excel. Quatro possuíam tamanhos com 20, 50, 100 e 500 unidades amostrais, extraídas de uma população com distribuição Normal, com média e desvio-padrão iguais a 0 e 1, respectivamente. As outras quatro amostras, também de tamanhos 20, 50, 100 e 500 unidades amostrais, foram extraídas de uma população com distribuição exponencial, ou seja, não Normal, com média e desvio-padrão iguais a 0 e 1, respectivamente. Deste modo, com a finalidade de verificar a suposição de normalidade, foram empregados os quatro testes de normalidade existentes no software estatístico Gretl: teste Jarque-Bera, teste Doornik-Hansen, teste Shapiro-Wilk e teste Kolmogorv-Simirnov Lilliefors. Ao final do procedimento, foram determinados os p-valores para serem interpretados com os níveis de significância habitualmente utilizados: $5 \%$ e $1 \%$.

\section{RESULTADOS E DISCUSSÃO}

Por meio da Tabela 01 e dos gráficos da Figura 01, pode-se visualizar os resultados obtidos pelos testes de normalidade avaliados neste estudo, para cada uma das amostras estudadas. Salienta-se que a hipótese nula dos quatro testes de hipóteses considerados neste estudo é a mesma, ou seja, os dados seguem uma distribuição Normal.

Para as 04 amostras geradas a partir de uma distribuição Normal espera-se que no mínimo 95\% e 99\% dos testes a hipótese nula não seja rejeitada e que em no máximo 5\% e 1\% deles a amostra seja rejeitada, o que ocorreu. Todos os testes não encontraram evidencias de não normalidade em todas as amostras simuladas tanto ao nível de significância de $5 \%$ como de 1\%, havendo uma certa tendência do p-valor ser maior nas amostras de menor tamanho.

Tabela 1: Resultados dos testes de normalidade

\begin{tabular}{|c|c|c|c|c|c|}
\hline \multirow[t]{2}{*}{ Teste } & \multirow[t]{2}{*}{ Distribuição } & \multicolumn{4}{|c|}{ p-valor } \\
\hline & & $\mathrm{n}=20$ & $\mathrm{n}=50$ & $\mathrm{n}=100$ & $n=500$ \\
\hline \multirow{2}{*}{ Doornik-Hansen } & Normal & 0.3659 & 0.3196 & 0.9673 & 0.1175 \\
\hline & Não Normal & 0.0778 & 0.0004 & $<0.0001$ & $<0.0001$ \\
\hline \multirow{2}{*}{ Shapiro-Wilk } & Normal & 0.7266 & 0.8433 & 0.8865 & 0.1377 \\
\hline & Não Normal & 0.0373 & 0.0002 & $<0.0001$ & $<0.0001$ \\
\hline \multirow{2}{*}{ KS-Lilliefors } & Normal & 0.6300 & 0.8600 & 0.4000 & 0.3200 \\
\hline & Não Normal & 0.2500 & $<0.0001$ & $<0.0001$ & $<0.0001$ \\
\hline \multirow{2}{*}{ Jarque-Bera } & Normal & 0.6403 & 0.7844 & 0.9436 & 0.1238 \\
\hline & Não Normal & 0.3560 & 0.0732 & 0.0054 & $<0.0001$ \\
\hline
\end{tabular}

Fonte: os autores, 2020. 


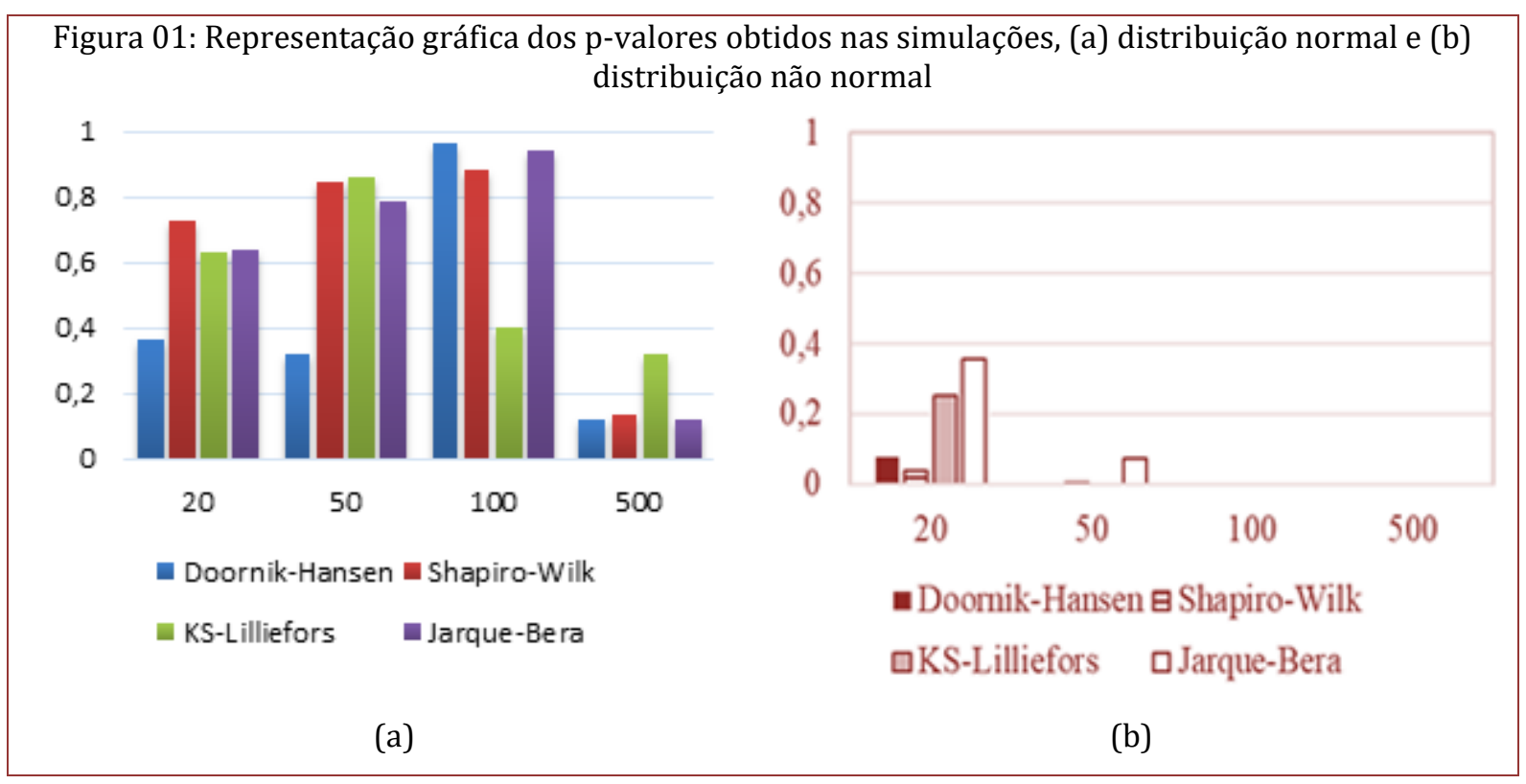

O comportamento do p-valor dos testes Shapiro-Wilk e Jarque-Bera foram similares, aumentando com o aumento do tamanho da amostra até $n=100$ e diminuindo abruptamente para $n=500$. No teste KS-Lilliefors, o maior valor $\mathrm{p}$ foi encontrado para $\mathrm{n}=50$ e não para $\mathrm{n}=100$, como aconteceu com os demais. Já o teste Dornik-Hansen apresentou os menores p-valores, com exceção da amostra com $n=100$, sendo neste caso superior aos demais. Nas amostras de tamanho maior, $n=500$, o melhor desempenho foi obtido pelo teste KS-Lilliefours.

Para as 04 amostras geradas a partir de uma distribuição não Normal espera-se que sejam encontradas evidências de não normalidade por rejeitar a hipótese nula, o que não aconteceu. Para pequenas amostras, $\mathrm{n}=20$, o teste de Shapiro-Wilk obteve o melhor resultado, pois foi o único que conseguiu identificar evidências de não normalidade para um nível de significância de 5\%. Para um nível de significância de 1\%, evidências de não normalidade não teriam sido encontradas. Já para amostras com $n=50$, o teste JarqueBera foi o único que não encontrou evidências de não normalidade, mesmo para um nível de significância de 5\%. Para amostras com $n=100$ e $n=500$, todos os testes encontraram evidências de que os dados amostrais não provêm de uma distribuição normal. Cabe salientar que para a amostras criadas a partir de distribuições sem normalidade, todos os testes avaliados apresentaram os maiores valor $\mathrm{p}$ em amostras com tamanho de 20 unidades.

\section{CONSIDERAÇÕES FINAIS}

Para os dados gerados a partir de distribuições normais, os quatro testes de normalidade mostraram-se equivalentes, com bons resultados e não identificando evidências de não normalidade em nenhuma das situações analisadas, muito embora o valor $\mathrm{p}$ tenha diminuído consideravelmente nas testagens das amostras de tamanho 500, fato que deve ser melhor investigado. No entanto, para dados gerados a partir de distribuições não normais, foi possível observar diferenças de acordo com o tamanho da amostra, assim como o teste utilizado. Para amostras de maior tamanho, todos os testes apresentam bons resultados na observação de identificação de evidências de não normalidade. Quando o tamanho da amostra diminuiu, entretanto, os testes começaram a apresentar problemas para a identificação da não normalidade. Na sondagem realizado, destaca-se o desempenho obtido pelo teste de Shapiro-Wilk, que se mostra superior aos demais, concluindo-se que este é, aparentemente, o melhor teste de aderência à normalidade para pequenas amostras, entre aqueles analisados. Por outro lado, o teste Jarque-Bera, largamente utilizado na verificação desta propriedade em séries temporais, apresentou baixo poder quando aplicado à pequenas amostras.

No entanto, novas simulações devem ser realizadas com a geração de uma quantidade maior de amostras para confirmar estes achados. Também poderiam ser utilizadas diferentes distribuições de probabilidade em sua geração, com manipulação de alguns parâmetros destas distribuições. 


\section{REFERÊNCIAS}

[1] ABDI, H. \& MOLIN, P., (2007). Lilliefors/Van Soest's test of normality. Encyclopedia of Measurement and Statistics. Disponível em: http://www.utdallas.edu/ herve/Abdi-Lillie2007-pretty.pdf. Acesso em dezembro, 2016.

[2] ADKINS, L. C., (2010). "Using gretl for Principles of Econometrics". 3. ed. Disponível em: http://www.learneconometrics.com/gretl/ebook.pdf. Acesso em janeiro, 2018.

[3] BUENO, R. D. L.S., (2011). “Econometria de séries temporais”. 2 ed. São Paulo: Editora Cengage Learning.

[4] COTTRELL, A., LUCCHETTI, R. J. (2018). GRETL: GNU Regression, Econometrics and Timeseries Library. Disponível em: http://gretl.sourceforge.net/. Acesso em abril, 2018.

[5] JARQUE, C., \& BERA, A., (1987). A test for normality of observations and regression residuals. International Statistical Review 55, 163-172.

[6] LUCAMBIO, F., (2008) Diferentes testes para verificar normalidade de uma amostra aleatória. 1. ed. Statistic research of Paraná, 1, 1-12.

[7] MORETTIN, P. A., (2011). Econometria Financeira. 2. ed. São Paulo, SP. Blucher.

[8] RAZALI, N. M., \& WAH, Y. B. (2011). Power Comparisons of Shapiro-Wilk, Kolmogorov-Smirnov, Lilliefors and Anderson-Darling Tests. Journal of Statistical Modeling and Anlytics, 2, 21-33.

[9] ROYSTON, J. P., (1982). Algorithm AS 181: the W test for normality. Journal of the Royal Statistical Society: série C - apllied statistics, 31(2), 176-180. 


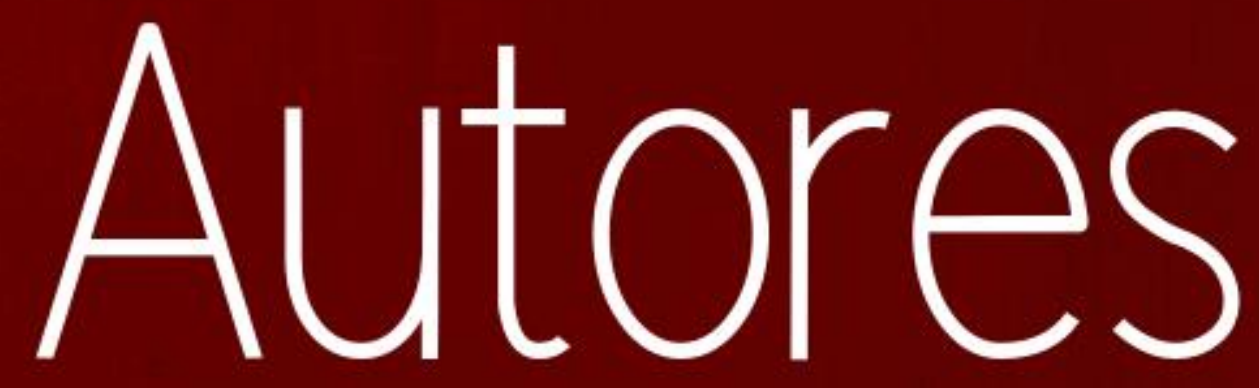




\section{MARIA CÉLIA DA SILVA GONÇALVES (ORGANIZADORA)}

Pós-doutorado em Educação pela Universidade Católica de Brasília (UCB). Estágio Pós-doutoral em Economic History Department of Law, Economics, Management and Quantitative Methods-DEMM da Università degli Studi Del Sannio - UNISANNIO-(Benevento, Italy). Visiting Professor da Università degli Studi Del Sannio - UNISANNIO. Pós-doutoranda em História pela Universidade de Évora em Portugal. Possui doutorado em Sociologia pela Universidade de Brasília (2010),mestrado em História pela Universidade de Brasília (2003), especialização em História pela Universidade Federal de Minas -UFMG (1998). Graduação em Geografia(2012) pela Faculdade Cidade de João Pinheiro (FCJP) Complementação em Supervisão Escolar(1993) pelas Faculdades Integradas de São Gonçalo, graduação em em História (1991) e em Estudos Sociais (1989) pela Faculdade do Noroeste de Minas. Atua como professora de História do Direito, Sociologia e Metodologia Científica Faculdade do Noroeste de Minas (FINOM). Coordenadora do Núcleo de Pesquisa e Iniciação Científica e Professora de Trabalho de Conclusão de Curso (TCC) nos cursos de Pedagogia, Administração da Faculdade Cidade de João Pinheiro (FCJP). Avaliadora do Sistema Nacional de Avaliação da Educação Superior do Ministério da Educação - MEC/INEP. Presidente do Conselho Municipal do Patrimônio Cultural de João Pinheiro(MG). Atualmente é pesquisadora do Comunidade Escolar: Encontros e Diálogos Educativos - CEEDE, do Programa de Pós- Graduação em Educação da UCB .Membro da KINETÈS - Arte. Cultura. Ricerca. Impresa (UNISANNIO). Investigadora visitante no CIDEHUS Centro Interdisciplinar de História, Culturas e Sociedades da Universidade de Évora em Portugal. Ocupante da cadeira de número 35 na Academia de Letras do Noroeste de Minas. Tem experiência na área de História e Sociologia, atuando principalmente nos seguintes temas: artes-folia- festascultura popular-performance- identidade e memória.

\section{BRUNA GUZMAN DE JESUS (ORGANIZADORA)}

Graduada em Pedagogia: docência e gestão pela PUC Minas (2009), pós-graduada em Orientação, Supervisão e Gestão Escolar (2020) assim como em Metodologia do Ensino de Língua Portuguesa e Língua Estrangeira (2014) pelo Grupo Educacional UNINTER/ FACINTER - Faculdade Internacional de Curitiba. Pós-graduanda em Neuropsicopedagogia pela Faculdade Metropolitana - MG. É Coordenadora Pedagógica.

\section{ADELSON GOMES DA SILVA}

Formado em Pedagogia, mestre em Desenvolvimento local pela Universidade de Valência - Espanha, especialista em Educação de Jovens e Adultos, mestre e doutorando em Educação pelo Programa de Pós-Graduação em Educação (PPGE) da Universidade Federal de Alagoas (UFAL), professor efetivo da Secretária Municipal de Educação de Maceió.

\section{ADRIANA APARECIDA DAS NEVES DEQUEIROZ}

Professora concursada da Universidade do Estado do Amazonas. Doutoranda pela Universidade Interamericana. Mestre em Sociolinguística pela Universidade do Estado do Mato Grosso do Sul. Especialista em Educação Inclusiva e Língua Portuguesa, membro do grupo de estudos NUPESDD Núcleo de Pesquisa e Estudos Sociolinguísticos e Dialetológicos da Universidade Estadual de Mato Grosso do Sul. Coordenadora de projetos semestrais desenvolvidos nas escolas do município. Graduada em Letras pela Universidade do Estado do Amazonas (2006). Atual coordenadora do Programa de Residência Pedagógica do Curso de Letras em Tabatinga-AM. Coordenadora do Programa Institucional de Bolsas de Iniciação à Docência (PIBID) do Curso de Letras no período de 2013 a 2016, Coordenadora do Curso de Letras no centro de Tabatinga de 2013 a 2015. Professora VOLUNTÁRIA do PARFORProfessora concursada da Universidade do Estado do Amazonas. Mestre em Sociolinguística pela Universidade do Estado do Mato Grosso do Sul. Especialista em Educação Inclusiva e Língua Portuguesa, membro do grupo de estudos NUPESDD - Núcleo de Pesquisa e Estudos Sociolinguísticos e Dialetológicos, do(a) Universidade Estadual de Mato Grosso do Sul. Coordenadora de projetos semestrais desenvolvidos nas escolas do município. Graduada em letras pela Universidade do Estado do Amazonas (2006). Doutoranda pela Universidade Interamericana. Atual coordenadora do Programa de Residência Pedagógica do Curso de Letras em Tabatinga-AM. Coordenadora do Programa Institucional de Bolsas de Iniciação à Docência (PIBID) do Curso de 
Letras no período de 2013 a 2016, Coordenadora do Curso de Letras no centro de Tabatinga de 2013 a 2015. Professora VOLUNTÁRIA do PARFOR

\section{ALAN RANGEL ALVES}

Administrador, formado pelo Centro Universitário Fundação Santo André (CUFA), com pósgraduação em Gestão em Saúde (UNIFESP), e MBA em Controladoria e Finanças (UNICSUL) e Mestrando Ciências Ambientais pela Universidade Brasil. Professor Universitário e Cursos Técnicos, possui mais de 18 anos de experiência na área administrativa, suprimentos, financeiro e contábil. É especialista em Gestão Estratégica, Controladoria e Projetos.

\section{AMANDA MARQUES DE CARVALHO GONDIM}

Doutora em Educação. Professora nas redes estadual de Pernambuco e municipal de Jaboatão dos Guararapes.

\section{ANA CLAUDIA RAMOS SACRAMENTO}

Professora Associada do Departamento de Geografia da Faculdade de Formação de Professores (FFP/Uerj). Licenciada em Geografia pela Universidade do Estado do Rio de Janeiro (Uerj, 2001). Mestra em Educação pela FE-USP (2007). Doutora em Geografia Física pela DG-FFLCH-USP (2012). Possui experiência como professora das redes pública e privada dos ensinos fundamental e médio. Atualmente é coordenadora de Projetos pela Faperj e é bolsista Jovem Cientista do Nosso Estado pela Faperj (2018). Trabalha com curso de formação de professores. Coordenadora do Grupo de Estudos e Pesquisa em Geografia, Educação e Cidades (GEPGEC). Desenvolve pesquisas e atua na área de ensino de Geografia, principalmente nos seguintes temas: educação geográfica, formação de professores, currículo e didática de Geografia.

\section{ANA LISA NISHIO}

Doutora em Educação, Mestre em Ensino de Ciências e Matemática, possui graduação em Matemática pela Universidade Federal Rural do Rio de Janeiro (1999). Atualmente é Professora Adjunta da Universidade Federal Rural do Rio de Janeiro. Tem experiência na área de Matemática, com ênfase em o uso de Tecnologias Digitais de Informação e Comunicação no Ensino da Matemática e Ensino de Cálculo Diferencial e Integral. Atuação por seis anos em trabalhos e pesquisas na Área de Educação a Distância na UAB/UFF como tutora no curso de Especialização em Novas tecnologias no Ensino da Matemática.

\section{ANDRÉ LUIS BONAVENTURA}

Licenciado em Física (2010) pela Universidade Estadual Paulista (UNESP - campus de Presidente Prudente - SP). Mestre e bacharel em Astrofísica Experimental (2013) pelo Instituto Nacional de Pesquisas Espaciais (INPE - campus de São José dos Campos -SP). Doutor em Ciências e Engenharia dos Materiais pela Universidade Federal de São Paulo (UNIFESP - campus São José dos Campos - SP). Atualmente dedica pesquisas no Ensino de Física, Astrofísica e Engenharia (ciências dos materiais e empreendedorismo).

\section{ANDRÉA CRISTINA KONRATH}

Possui graduação em Matemática Aplicada e Computacional pela Universidade de Santa Cruz do Sul (2000), mestrado em Engenharia de Produção pela Universidade Federal de Santa Catarina (2002) e doutorado em Engenharia Mecânica pela Universidade Federal de Santa Catarina (2008). Trabalhou como docente na área de Estatística na Universidade do Vale do Itajaí, (UNIVALI), no período de março de 2007 a janeiro de 2009, e, no Instituto de Matemática, Estatística e Física da Universidade Federal do Rio Grande (FURG), no período de fevereiro de 2009 a julho de 2011, também na área de Estatística. Desde agosto de 2011, é Professora Associada na Universidade 
Federal de Santa Catarina (UFSC), pertencendo ao Departamento de Informática e Estatística, na qual ministra disciplinas de Estatística na graduação e pós-graduação. Florianópolis, SC, Brasil.

\section{ARLANE QUEIROZ PEREIRA}

Licenciatura Plena em Pedagogia (2020) pela Universidade Estadual do Paraná Campus de Paranaguá.

\section{BARBARÁ ALVES NASCIMENTO MARQUES}

Cursa graduação em engenharia mecânica no Instituto Federal de São Paulo e é apaixonada por física e astronomia.

\section{CAROLINA SCALISE TAQUES FONSECA SCHLUMBERGER}

Professora do Departamento de Administração da Universidade Estadual de Ponta Grossa (PR), doutora em Administração - Organizações, Gestão e Sociedade, pela Universidade Positivo, Curitiba (2018), mestre em Administração - Estratégia e Análise Organizacional, pela Universidade Federal do Paraná (2001) e graduada em Administração pela Universidade Estadual de Ponta Grossa (1998). Coordena projetos e eventos de extensão sobre o tema Internacionalização e Mobilidade Acadêmica. Integra o grupo de pesquisa "Organização e subjetividade" (UP) e o "Nucleo de Estudos e Pesquisas: Organização e Sociedade"(UEPG). Seu interesse de pesquisa está ligado às áreas de Estudos Organizacionais e Comportamentais, com ênfase em cultura e interculturalidade, sentidos do trabalho, internacionalização e mobilidade acadêmica.

\section{CAROLLINI SILVA THOMAZ GRACIANI}

Pedagoga. Neuropsicopedagoga. Especialista em Supervisão Pedagógica e Orientação Educacional. Especialista em Ensino a Distância. Especialista em estudos relacionados ao bullying escolar. Atualmente Coordenadora do Curso de Pedagogia da Estácio Resende-RJ e professora universitária.

\section{CLARICE FARIAN DE LEMOS}

Prof. Dra. Clarice Farian de Lemos, graduada em Engenharia Civil pela Universidade Federal do Paraná (UFPR), em 1990; especialista em Segurança do Trabalho, em 1993, pelo CEFET/PR; mestre em Agronomia, na área de Ciências do Solo, em 2002; doutora em Geologia, na área de Geologia Ambiental, em 2010, pela UFPR e desde 1994 atua como docente pela Universidade Tecnológica Federal do Paraná (UTFPR).

\section{DAVID DE BRITO}

Pedagogo Mestre em Educação Doutor em Teologia Doutorando em Educação

\section{DAYANE LIMA VIANA}

Doutoranda pela Universidade Federal de Santa Catarina- UFSC (2020). Mestre em Linguística UFAM (2019). Formada em Letras pela Universidade do Amazonas UEA (2016). Pesquisadora de assuntos dialetológicos.

\section{DEIVYSON ANDERSON SILVA CANDIDO}

Mestrando em Física de Partículas, Cosmologia e Gravitação pela Universidade Federal de Campina Grande. Graduado em Licenciatura em Física pela Universidade Estadual da Paraíba (2019). Atualmente faço parte do projeto BINGO, tal projeto trata-se do primeiro rádio telescópio implantado na Paraíba em convenio pela UFCG. Foi bolsista no Programa Institucional de Bolsas de Iniciação à Docência (PIBID), no ano de 2016 até 2018, e no programa Residência Pedagógica no ano 
de 2018 até 2020. Tem experiência em lecionar aulas de Física direcionada as turmas do Ensino Médio.

\section{EDUARDO ALBERTO DA SILVA}

Doutor em Educação: Psicologia da Educação pela Pontifícia Universidade de São Paulo-PUC-SP (2018), Mestre em Psicologia pela Universidade Metodista de São Paulo-UMESP (2013).

\section{ELIONE MARIA NOGUEIRA DIÓGENES}

Possui graduação em Licenciatura Plena em História pela Universidade Federal do Ceará (UFC); Mestrado no Programa de Pós-Graduação em Avaliação de Políticas Públicas; Doutorado e PósDoutorado na área de Políticas Públicas da Educação, no Programa de Pós-Graduação em Políticas Públicas da Universidade Federal do Maranhão (UFMA). Atualmente é Professora Associada I da Universidade Federal de Alagoas (UFAL).

\section{EUGÊNIO MAURÍCIO DA SILVA NETO}

Graduação em Administração com Habilitação em Comércio Exterior pela Universidade Estadual de Ponta Grossa (2002). MBA em Comércio Internacional - IBPEX 2006. Especialização em Gestão Industrial - Conhecimento e Inovação - UTFPR - Ponta Grossa - 2011, Mestre em Engenharia de Produção - UTFPR 2014 - Gerente de exportação - Madeireira Jobb 2011. Experiência na área de Administração, com ênfase em COMÉRCIO EXTERIOR, professor da UNIVERSIDADE ESTADUAL DE PONTA GROSSA desde 2009 com as disciplinas de Gestão Estratégica, Teoria Geral da Administração e Gestão Internacional de Negócios, Sistemática de Comércio Exterior e Introdução ao Comércio Exterior, disciplina de Estágio I. Atualmente atuo como Coordenador do Programa de Extensão Printe - Programa de Internacionalização, Trabalho e Empreendedorismo dos Cursos de Administração e Administração com Linha de Formação em Comércio Exterior, Vice coordenador do Curso de Administração e Administração com Linha de Formação em Comércio Exterior da Universidade Estadual de Ponta Grossa.

\section{EVANDRO CHERUBINI ROLIN}

Professor do IFPR, campus Curitiba com graduação em Engenharia Elétrica pela UDESC, especialização em Telecomunicações pela UFPR, especialização em Docência no Ensino Superior pelo UNICESUMAR, complementação pedagógica para docentes não licenciados pela Faculdade Avantis/SC, especialização em Políticas Educacionais pela UFPR e mestrado em Eng. Elétrica pela UFPR e doutorando em Eng. Mecânica na PUC-PR. Possui experiência como coordenador de Cursos Técnicos, Cursos Superiores de Tecnologia, Engenharias e Cursos de Especialização, além de Coordenador e Diretor de Ensino da Pró-Reitoria de Ensino, Diretor do Núcleo de Apoio a Processos de Seleção, Pró-Reitor de Planejamento e Desenvolvimento Institucional, além de membro titular dos Conselhos de Ensino, Pesquisa e Extensão; do Conselho de Administração e Planejamento; do Conselho Superior e do Colégio de Dirigentes.

\section{GABRIELA CARRADAS}

Graduanda em Pedagogia pelo Centro Universitário UniMetrocamp Wyden em Campinas.

\section{GÉRSON DOS SANTOS NUNES}

Possui graduação em Engenharia Elétrica pelo Instituto Federal Sul-Rio-Grandense (2014), com especialização em Docência no Ensino Superior pelo Centro Universitário Barão de Mauá (2015). Mestre pelo Programa de Pós-Graduação em Modelagem Computacional (PPGMC), na Universidade Federal do Rio Grande (FURG) (2019). Atualmente, é professor EBTT do Instituto Federal de Educação, Ciência e Tecnologia do Rio Grande do Sul - Rio Grande, RS, Brasil. 


\section{GIVANILDO MELO DOS SANTOS}

Mestre em Ciências da Educação, Pós graduado em Ensino da Matemática, Gestão Escolar e Coordenação Pedagógica, Ensino Híbrido, Ensino a Distância e Metodologias Ativas, Técnico em Conselhos Escolares, Formador, Palestrante.

\section{GUSTAVO LACERDA DIAS}

Prof. Dr. Gustavo Lacerda Dias - formado em Engenharia Civil pela UFJF em 1994, é professor efetivo da UTFPR Câmpus Pato Branco desde 2006. Possui mestrado (2000) e doutorado (2005) em Engenharia Civil pela UFSC na área de Estruturas.

\section{GYOVANNA KELLY MATIAS DO NASCIMENTO}

Mestranda do Programa de Pós Graduação em Física da Universidade Federal de Campina Grande (UFCG). Graduada em Licenciatura em Física, pela Universidade Estadual da Paraíba (2019). Foi bolsista do Programa Institucional de Bolsas de Iniciação à Docência (PIBID) de 2016 a 2018 e da Residência Pedagógica (RP) de 2018 a 2020 pela Universidade Estadual da Paraíba. Foi monitora do Programa de Apoio à Formação e ao Ensino (PROAFE), no ano de 2018 e possui experiência em lecionar Física direcionada ao ensino médio regular.

\section{JANAÍNA RODRIGUES DE ALMEIDA}

Acadêmica de Administração com linha de formação em Comércio Exterior da Universidade Estadual de Ponta Grossa. Integrante do projeto de extensão intitulado Departures.

\section{JOÃO PAULO TENÓRIO}

Especialista em Design Digital e Novas Mídias pelo Centro Universitário Belas Artes de São Paulo (2017). Graduado em Design na Universidade São Judas Tadeu (2014), Tecnólogo em Comunicação para Web (Web Design) na Universidade Paulista (2008). Técnico em Design Gráfico pela ETEC José Rocha Mendes (2006). Autor do artigo Concepção e design para material didático on-line. Possui mais de 10 anos de experiência tanto na produção de peças gráficas e interativas como em desenvolvimento nas plataformas Joomla e Wordpress. Conhecimento nos (LMS) webAula, Moodle, Canvas, além de técnicas de SEO, animação e edição de vídeo.

\section{JOSÉ EDIELSON DA SILVA NEVES}

Possui graduação em Pedagogia pelo Instituto de Ensino Superior Múltiplo (2017) e graduação em Matemática Licenciatura, pela Universidade Estadual da Paraíba (2018) Graduando em Física Licenciatura, pela Universidade Estadual da Paraíba (UEPB), Especialização Em Psicopedagogia Institucional pelo Sintep (2019). Atualmente é professor de Matemática e Física na Secretaria de Educação do Estado da Paraíba, SEE-PB. Tem experiências na Educação Básica, no Ensino Fundamental e Médio, e na Educação de Jovens e Adultos (EJA) e também em Programas do Governo Federal (Mais Educação e Brasil Alfabetizado).

\section{JUSSARA CASSIANO NASCIMENTO}

Pós-Doutora em Educação pela Universidade do Estado do Rio de Janeiro, Doutora pela Universidade Católica de Petrópolis, Mestre em Educação pela Universidade Federal do Estado do Rio de Janeiro, , Pedagoga formada pela Universidade do Estado do Rio de Janeiro; Psicopedagoga e Supervisora Escolar, Especialista em Educação Infantil pela PUC/ RJ atuando principalmente nos seguintes segmentos: Memória, História, Formação de Professores, Práticas Educativas e Instituições Escolares. 


\section{JUVANCIR DA SILVA}

Graduado em Administração pela Universidade Estadual de Maringá (1996), mestrado em Engenharia de Produção pela Universidade Federal de Santa Catarina (2002) e doutorado em Gestão Ambiental pela a Universidade Positivo (2017). Atualmente é professor Adjunto da Universidade Estadual de Ponta Grossa. Tem experiência na área de Administração, com ênfase em Administração de Logística, atuando principalmente nos seguintes temas: Gerenciamento da Cadeia de Suprimentos e Desenvolvimento Sustentável.

\section{KENIA KEMP}

Historiadora pela UFPE. Mestre em Antropologia Social pela UNICAMP. Docente do ensino superior e pesquisadora em áreas temáticas como Sociologia da Educação, Identidade Cultural e Multiculturalismo, História e Patrimônio Cultural, Comunicação e Cultura e Sociologia da Cultura.

\section{LARISSA COSTA SOUZA}

Licenciatura Plena em Pedagogia (2021) pela Universidade Estadual do Paraná Campus de Paranaguá.

\section{LEONARDO DIAS DA SILVA}

Formado em Ciências Contábeis pela Universidade Estácio de Sá (2014) e graduação em Gestão de Recursos Humanos pelo Centro Universitário de Volta Redonda (2006). Atualmente é coordenador e professor nos cursos de negócios da Universidade Estácio de Sá. Proprietário e Contador na Conline Assessoria Contábil. Tem experiência na área de Administração, com ênfase em Recursos Humanos, atuando principalmente nos seguintes temas: comércio varejista, setor automobilístico, qualidade de atendimento e ruídos de comunicação.

\section{LETICIA IZABELA FERREIRA GUIMARÃES GODOI}

Licenciatura Plena em Pedagogia (2020) pela Universidade Estadual do Paraná Campus de Paranaguá.

\section{LO RUAMA DYENIFER PASSOS DE SOUZA}

Ensino Médio: Formação de Docentes/ Magistério, pela instituição de ensino Dr. Caetano Munhoz da Rocha e Licenciatura Plena em Pedagogia (2020) pela Universidade Estadual do Paraná Campus de Paranaguá.

\section{LUANA CARLA BERNARDO}

Curso Superior de Tecnologia em Logística (2014) pela Faculdade de Tecnologia FAESA, Licenciatura Plena em Pedagogia (2020) pela Universidade Estadual do Paraná Campus de Paranaguá e Pós Graduação em Gestão Escolar (2020) pela Universidade Positivo.

\section{LUIZ RICARDO NAKAMURA}

Possui graduação em Estatística pela Universidade Estadual Paulista "Júlio de Mesquita Filho" (2009), mestrado em Ciências (Estatística e Experimentação Agronômica) pela Universidade de São Paulo (2011) e doutorado em Ciências (Estatística e Experimentação Agronômica) pela Universidade de São Paulo (2016), com período "sanduíche” na London Metropolitan University (Londres, Reino Unido). Atualmente, é Professor Adjunto do Departamento de Informática e Estatística da Universidade Federal de Santa Catarina. Pesquisador dos grupos GAMLSS (www.gamlss.org) e "Grupo de Análise e Modelagem Estatística - GAME". Tem experiência na área de Probabilidade e Estatística, com ênfase em Probabilidade e Estatística Aplicadas, atuando, principalmente, nos seguintes temas: modelos aditivos generalizados para locação, escala e forma 
(GAMLSS), modelos semiparamétricos, modelagem estatística e análise multivariada. Florianópolis, SC, Brasil.

\section{MANUELA GOMES MAUÉS}

Graduanda do curso de licenciatura plena em matemática pela Universidade do Estado do Pará, voluntária do PIBID (Programa Institucional de Bolsas de Iniciação à Docência) subprojeto de matemática, voluntária do Lema (Laboratório de Educação Matemática) e bolsista de Monitoria.

\section{MARIA BERNADETTE FROTA AMORA SILVA}

Doutorado em Engenharia Civil na Universidade Federal do Ceará (2012). Possui graduação em Engenharia Civil pela Universidade de Fortaleza (1982) e mestrado em Administração de Empresas pela Universidade de Fortaleza (2003). Tem experiência na área de Engenharia e Gestão, com ênfase em Apoio a Decisão.

\section{MARIA IEDA MONTEIRO}

Mestre em Educação Linguagem Tecnologia e Gestão pela Universidade do Sul de Santa Catarina (Unisul). Bacharel em Química e Ciências pela Universidade de Passo Fundo. Atualmente é proprietária e CEO do grupo FAIEP, com polos de Educação a Distância em parceria com o Centro Universitário Leonardo Da Vinci (Uniasselvi). Possui experiência em Credenciamento e Recredenciamento de IES, além de autorização e recredenciamento de cursos. Atua na Educação a Distância desde 1999, sendo uma das pioneiras no Estado de Santa Catarina no que diz respeito a esta metodologia de Ensino. Atuou também no desenvolvimento de Propostas Curriculares tanto municipais, quanto do Estado de Santa Catarina, além de já ter atuado como Diretora Acadêmica, Coordenadora Geral de Pós-graduação Lato Sensu e Coordenadora Geral de Polo EAD da SECAB.

\section{MÁRIO HENRIQUE MONTEIRO NASCIMENTO}

Pedagogo pela Universidade Federal de Pernambuco (2003), Especialista em Psicopedagogia Escolar pela UNINABUCO Recife (2010). Atuou como Orientador Educacional (2006 - 2008), Coordenador Pedagógico (2011 - 2015), Professor de Ética Socioambiental (2013). Na EAD, entre 2017 e 2020, esteve como Tutor Presencial na Laureate e Kroton. Atualmente está como Tutor Virtual no curso EAD de Letras da UFRPE desde outubro de 2020.

\section{OLAVIO VINÍCIUS BARBOSA NEVES}

Graduando em Física pela Universidade Estadual da Paraíba, presidente do Centro Acadêmico de Física - CAFIS (2017/18/19/20), Membro do Grupo de Teatro Científico Impetus (UEPB), Ex bolsista do Programa Residência Pedagógica - CAPES 2018/19, Ex monitor do Projeto de Extensão Pró-Enem (UEPB), Monitor do PROAFE - Programa de Apoio a Formação e ao Ensino (2020). Atualmente Bolsista do Programa Institucional de Bolsas de Iniciação Científica (PIBIC) no projeto intitulado: A Utilização do Arduíno na Aprendizagem da Física. Com experiência no campo de pesquisas sobre o Uso de Tecnologias em Sala de Aula, bem como a inserção da Artes no Ensino da Física.

\section{PAULA NOBRE DE ANDRADE}

Engenheira Civil pela Universidade Federal do Ceará (2014). Mestra em Engenharia Civil, modalidade Recursos Hídricos, pelo Departamento de Engenharia Hidráulica e Ambiental da Universidade Federal do Ceará (2017). Com visão humanística da engenharia, preza pela interdisciplinaridade das áreas, com fortes conceitos de socialização, inclusão, preservação e sustentabilidade do meio ambiente. Atualmente atuante como discente para os cursos de graduação em Arquitetura e Urbanismo, Engenharia Civil e Engenharia de Produção. 


\section{PAULO SIGA THOMAZ}

Graduado em Engenharia Civil pela Universidade Federal do Rio Grande (FURG) (2016). Fez intercâmbio acadêmico, cursando um ano de sua graduação na Budapest University of Technology and Economics (BME) (2014), na cidade de Budapeste, pelo programa do governo Ciência sem Fronteiras. Possui mestrado em Modelagem Computacional pela Universidade Federal do Rio Grande (FURG) (2019). Atualmente, cursa Licenciatura em Matemática pelo Centro Universitário Claretiano. Possui experiência com técnicas estatísticas aplicadas à qualidade, com ênfase na mensuração da satisfação, e estudos de séries temporais, principalmente séries econômicas e financeiras. Rio Grande, RS, Brasil.

\section{PEDRO STEINMÜLLER PIMENTEL}

Graduado em Física pela Universidade Estadual da Paraíba (UEPB) em 2019. Foi bolsista do Programa Institucional de Bolsas de Iniciação a Docência (PIBID) de 2016 a 2018 e da Residência Pedagógica (RP) de 2018 a 2019 pela Universidade Estadual da Paraíba. Tem experiência em lecionar aulas de Física direcionada as turmas do Ensino Médio. Atualmente é mestrando em Física de Partículas, Cosmologia e Gravitação pela Universidade Federal de Campina Grande (UFCG).

\section{PRISCILA DÉBORA RAMOS}

Pedagoga pela Universidade Estadual Vale do Acaraú- (UVA)2014, Especialista em Psicopedagogia Clínica e Institucional pela Faculdade Européia, Recife (2019). Especialista em Tecnologias e Educação a distância pela, Faculdade São Luís, SP(2019). Atuou como Assistente do Núcleo de Educação a distância (NEAD)2012 - 2014, pelo Grupo Laureate - Faculdade dos Guararapes. Atuou como Educadora Social pela Prefeitura de Jaboatão-PE (2014-2015). Atuou como Assistente de Polo EAD (2016 - 2019), pela UNIFACS, Grupo Laureate. Na EAD, 2019 e 2020, esteve como Tutor Presencial no Grupo Laureate, pela UNIFG-PE. Atualmente exerce como Tutora Online no curso EAD de Pedagogia do Grupo Ser Educacional, desde dezembro de 2020.

\section{RAQUEL MATCIULEVITZ MORAES DE OLIVEIRA}

Licenciatura Plena em Pedagogia (2021) pela Universidade Estadual do Paraná Campus de Paranaguá.

\section{REGINA CHAVES DOS SANTOS}

Bacharel em Psicologia Escolar pela Faculdade de Tecnologia e Ciências (FTC), 2009.2, campus de Vitória da Conquista - BA; Pós-graduada em Políticas Públicas para a Educação com ênfase em Diversidade Cultural e Controle Social pela Faculdade Hélio Rocha, 2017; Pós-graduada em Psicopedagogia Clínica e Institucional pela UNIGRAD Pós-Graduação campus de Vitória da Conquista - BA; Mestranda em Gerência e Administração de Políticas Públicas e Educacionais, pelo Instituto de Educação Superior Kyre'y Sãso campus de Vitória da Conquista - BA; Membro do projeto Cultural Sarau "A Estrada"; Poeta.

\section{RENATA SA BRITO STRAMANDINOLI}

Prof. Dra. Renata Sá Brito Stramandinoli - formada em Engenharia Civil pela Universidade Federal do Paraná (UFPR) em 2002, é professora efetiva da Universidade Tecnológica Federal do Paraná (UTFPR) desde 2010 e Coordenadora do Curso de Engenharia Civil do Campus Curitiba desde 2019. Possui Doutorado (2007) em Engenharia Civil pela Universidade Federal de Santa Catarina (UFSC) na área de Estruturas.

\section{RODRIGO BARBOSA}

Possui especialização em Metodologias Ativas pela ( UNINASSAU - 2020), especialização em Metodologia de Ensino à distância pela ( UNINASSAU - 2019) e Psicologia Organizacional e do Trabalho pela (FACOTTUR-2016), graduado em Gestão de Recursos Humanos pela Faculdade de 
Comunicação Tecnologia e Turismo de Olinda (2015), com experiência na área de RH nos subsistemas ( T\&D / R\&S). Foi voluntário atuante no projeto de inclusão à diversidade da Associação Brasileira de Recursos Humanos de Pernambuco (ABRH -PE). Atualmente, exerce a função de Tutor em EaD, dos cursos de Pós- Graduação na área de Gestão pelo Grupo Ser Educacional.

\section{ROSIVANDA CUNHA MORAES}

Graduada no curso de licenciatura plena em matemática pela Universidade do Estado do Pará e estudante de pós graduação - especialização na Faculdade de Educação e Tecnologia da Amazônia FAM.

\section{RUTH BRITO DE FIGUEIREDO MELO}

Doutora em Engenharia de Processos (UFCG) em 2019, Mestre em Ensino de Física (2011) e Licenciada em Física (UEPB) em 2003. Possui curso de aperfeiçoamento em TIC (Tecnologias da Informação e comunicação) e em Elaboração de Projetos, ambos pelo MEC/PROINFO e NTE (Núcleo de Tecnologia Educacional) da Paraíba, e de Atualização em EaD pela UEPB. Professora do Departamento de Física do Centro de Ciências Exatas e Tecnológicas da UEPB/CAMPUS I.

\section{STHEFANY DOS SANTOS PEREIRA}

Plena em Pedagogia (2021) pela Universidade Estadual do Paraná Campus de Paranaguá.

\section{SUNAMITA DE SOUZA BELIDO}

Formação em Pedagogia na Universidade Anhanguera -MT Pós graduada em Psicopedagogia na Faculdade Afirmativo -MT Mestranda em Educação na Universidade UNADES- PY

\section{SUZYNEIDE SOARES DANTAS VALCÁCIO}

Mestre em Educação(UFRN). Mestre em Ciência da Informação(UFPB). Especialista em Filosofia(UFRN). Pedagoga(UFRN). Medalha de Mérito Estudantil(UFRN). Atuação profissional na formação de professores da graduação e pós-graduação.

\section{SYLVIA CRISTINA DE AZEVEDO VITTI}

Docente de ensino superior na Faculdade de Tecnologia de Piracicaba - SP / FATEP. Doutoranda em Educação pela Universidade Metodista de Piracicaba - UNIMEP. Mestrado em Educação pelo Centro Universitário Salesiano de São Paulo (UNISAL), Especialização em Educação - Formação de Tradutores em Língua Inglesa pelo Centro Universitário Claretiano de Rio Claro (SP) e Especialização em Comunicação Empresarial pela Universidade Metodista de São Paulo (UMESP). Graduada em Letras (Inglês e Português - Licenciatura Plena) pela Universidade Metodista de Piracicaba - UNIMEP (2004). Trabalhou também por três anos como docente de ensino superior na Faculdade de Tecnologia Roque Trevisan/FATEC/ Centro Paula Souza, Piracicaba/SP. Atua como docente há mais de 20 anos. Desenvolve pesquisa em Educação, com foco em Educação Profissional e Tecnológica e Linguagens. Possui experiência no Ensino Superior, Médio, Fundamental II e em cursos livres. Graduada também em Engenharia Agronômica pela Escola Superior de Agricultura Luiz de Queiroz - ESALQ/USP (1995). Obteve o Certificado de Proficiência em língua inglesa (CPE) pela Universidade de Cambridge (Certificate of Proficiency in English / University of Cambridge UK) em Londres, onde residiu por 2 anos e meio e realizou diversos cursos de aprimoramento das habilidades linguísticas, além de ter trabalhado em ambiente multicultural. Possui Certificação Internacional TOEFL ITP (Effective Operacional Proficiency). É autora de diversos artigos em periódicos nacionais e do livro: Intercâmbio Cultural e Identidade ISBN 978-85-7656-039-5, São Carlos, SP. Editora Rima, 2016. 


\section{VIVIANE LEITE DIAS DE MATTOS}

Possui graduação em Engenharia Civil pela Universidade Católica de Pelotas (1978), mestrado em Engenharia de Produção pela Universidade Federal de Santa Catarina (1997) e doutorado em Engenharia de Produção pela Universidade Federal de Santa Catarina (2004). Trabalhou como docente na área de Estatística na Universidade Católica de Pelotas e na Universidade Federal Rural do Rio de Janeiro. Atualmente é Professora Associada no Instituto de Matemática, Estatística e Física da Universidade Federal do Rio Grande. Tem experiência na área de Engenharia de Produção, com ênfase em Garantia de Controle de Qualidade, atuando, principalmente, nos seguintes temas: séries temporais, qualidade, probabilidade e estatística, controle de processos e projeto de experimentos. Rio Grande, RS, Brasil.

\section{YURI RAVELL NOBRE COSTA}

Possui Licenciatura em Pedagogia pela UNIASSELVI (2020), graduação em Administração pela Universidade Potiguar (2017) e graduação em Gestão de Recursos Humanos pela Universidade Potiguar (2013). Atualmente é professor tutor da Universidade Federal Rural de Pernambuco, professor executor pós graduação ead do Centro universitário Maurício de Nassau - Recife, professor da graduação do Centro Universitário Maurício de Nassau e Coordenador do Curso de Pedagogia e Gestão de Recursos Humanos do Centro Universitário Maurício de Nassau. Cursando Psicologia (previsão de término 2021). Tem experiência na área de Administração, com ênfase em Recursos Humanos, atuando principalmente nos seguintes temas: sofrimento psíquico, saúde mental, clima, cultura, pesquisa de clima organizacional e psicopatologia. 
